LUIZ CELSO CASTRO DE TOLEDO

\title{
A FAMÍLIA NO DISCURSO DOS MEMBROS DE FAMÍLIAS HOMOPARENTAIS
}

Tese apresentada ao Instituto de Psicologia da Universidade de São Paulo para obtenção do Título de Doutor em Psicologia.

Área de Concentração: Psicologia Social e do Trabalho.

Orientadora: Profa. Dra.Vera Silvia F. Paiva

São Paulo

2008 
AUTORIZO A REPRODUÇÃO E DIVULGAÇÃO TOTAL OU PARCIAL DESTE TRABALHO, POR QUALQUER MEIO CONVENCIONAL OU ELETRÔNICO, PARA FINS DE ESTUDO E PESQUISA, DESDE QUE CITADA A FONTE. 


\section{A FAMÍLIA NO DISCURSO DOS MEMBROS DE FAMÍLIAS HOMOPARENTAIS}

Luiz Celso Castro de Toledo

BANCA EXAMINADORA

(Nome e Assinatura)

(Nome e Assinatura)

(Nome e Assinatura)

(Nome e Assinatura)

(Nome e Assinatura)

Tese defendida e aprovada em: 
Aos entrevistados,

Que generosamente concordaram em conversar com um estranho sobre temas e passagens importantes de suas vidas

à Ana Cristina e à Gabi, meus dois amores e ao Luiz Antonio, que me faz muita falta. 


\section{Agradecimentos}

Muitas pessoas participaram da construção dessa pesquisa junto comigo. Todos esses colaboradores foram fundamentais, sem eles esse trabalho não teria se tornado possível ou certamente não teria sido tão interessante, nem tão divertido.

Professora Vera Silvia F. Paiva, que me apoiou, incentivou, corrigiu e instigou desde quando a idéia de pesquisar esse tema começou a formar-se. Seu carinho, dedicação e incentivo foram fundamentais para mim durante esses últimos anos;

Professora Marlene Guirado, que debateu, incentivou e sugeriu questões para os roteiros utilizados aqui e sempre mostrou-se disposta a dialogar sobre o seu método de pesquisa com generosidade e respeito as minhas idéias;

Professora Belinda Mandelbaum, pela leitura cuidadosa e respeitosa, pelas sugestões e dicas durante o exame de qualificação;

Professora Anna Paula Uziel, por ter partilhado comigo o seu vasto conhecimento sobre a temática desse trabalho dando sugestões fundamentais para o aprimoramento da tese;

À ONG Rosa Vermelha e a todos os que nela trabalham, representados aqui por Joana D'arc e Juscely, que se dispuseram a me ouvir e a trocar idéias. E que, além disso, apresentaram a mim vários candidatos a entrevistados. Mais do que colaboradoras, ambas tornaram-se minhas amigas. Muito obrigado; 
Ao Grupo Videverso da USP, representado aqui pelo Prof. Dr. Manoel Antonio dos Santos e por Murilo Moscheta, que me receberam e auxiliaram desde a fase inicial desse projeto;

A Gercina Maria Castro de Toledo, Celso Falabella de Figueiredo Castro e Zuleika Bahiense Falabella de Castro que sempre me apoiaram e inspiraram;

Aos colegas de mestrado e doutorado orientados pela Professora Doutora Vera Paiva que se dispuseram a ler atentamente e a debater este trabalho durante a sua gestação;

A minha irmã Izabela Castro de Toledo que, de forma carinhosa e amiga, me recebeu tantas vezes em sua casa durante a realização deste trabalho;

Aos colegas e professores do Instituto Familiae, à Dra. Lenise Azoubel, à Patrícia Tittoto, à Maria Aparecida de Paiva Franco, à Alice Costa, à Marina Marques, Vitor Hugo Oliveira, Lafayette Tourinho, Ana Célia Puglia, Luciano Mesquita e à Bibi (que fez companhia).

Ao Departamento de Psicologia Social e do Trabalho do IPUSP e à CAPES que possibilitaram a realização desta tese. 


\section{ÍNDICE}

1. Introdução

1.1 A multiplicidade familiar......................................................................14

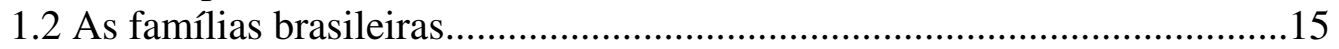

1.3 A mudança em outros países...........................................18

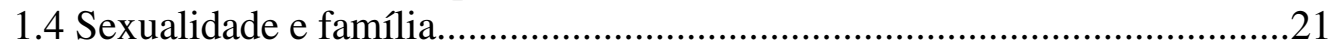

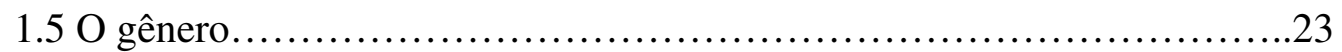

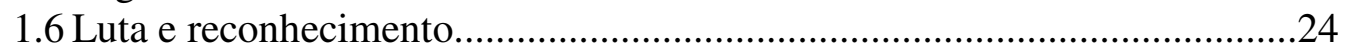

1.7 As Considerações da Igreja Católica e outras vozes religiosas..............26

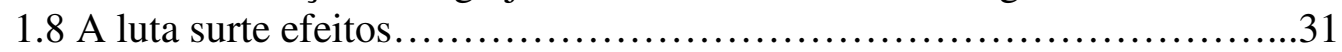

1.9 Dos tratamentos médicos da homossexualidade ao debate no campo

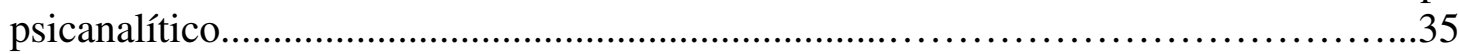

1.10 As psicoterapias e o debate sobre a sexualidade..................................43

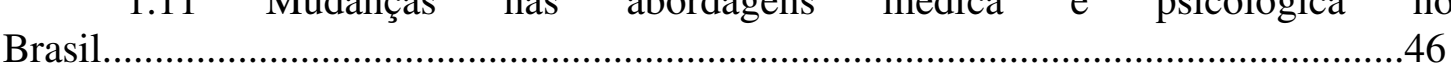

2. Objetivos

3. Método

3.1 O processo de contato e seleção de entrevistados......................................56

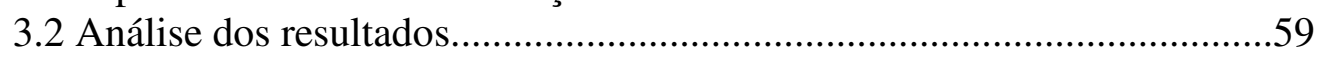

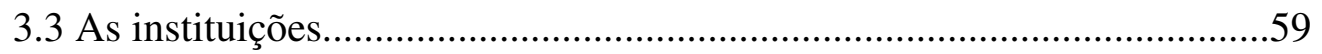

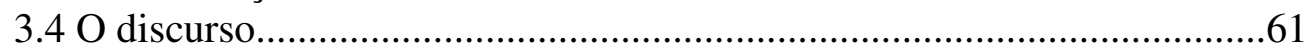

3.5 As vozes no discurso.............................................................................64

3.6 O sujeito-dobradiça a................................................................................66

3.7 O material das entrevistas.......................................................................68

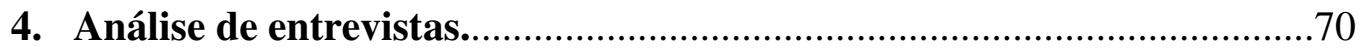

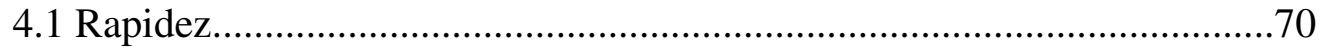

4.2 Companheirismo, apoio e ajuda...............................................................72

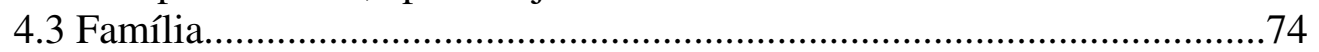

4.4 Família de origem................................................................................

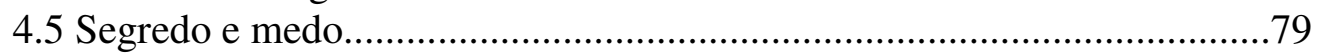

4.6 Aceitação e rejeição.................................................................................

4.7 Vozes religiosas.................................................................................90

4.8 Trabalho............................................................. 94

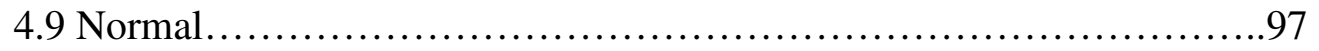

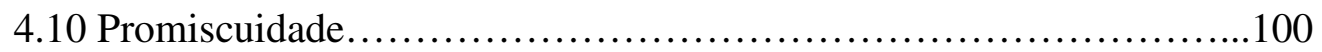

4.11 Atributos.......................................................

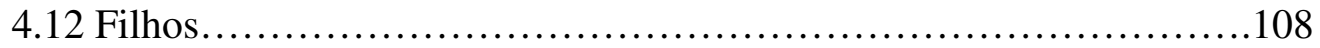

5. De volta às nossas questões.........................................115

5.1 De que forma se organizam os discursos desses entrevistados sobre a família?

5.2 De que modo os sujeitos descrevem suas famílias atual e de origem? 
5.3 Como descrevem as relações entre sua família e a sociedade? 118

5.4 Qual o lugar que os sujeitos se atribuíram ao discorrerem sobre o tema família?

5.5 Como se posicionam quando discorrem sobre filhos e adoção? 124

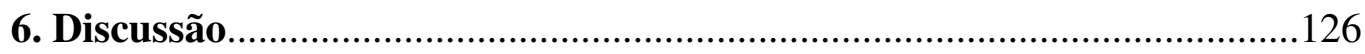

6.1 Do nascimento do homossexual à homoparentalidade..........................126

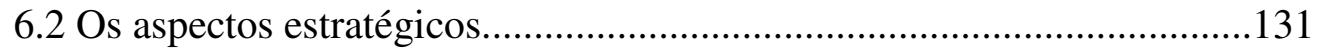

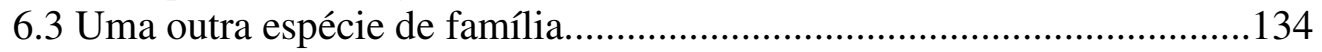

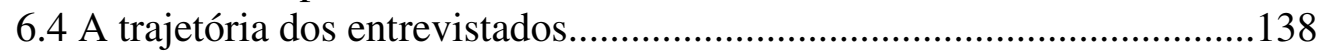

6.5 A Psicologia diante da homoparentalidade...........................................144

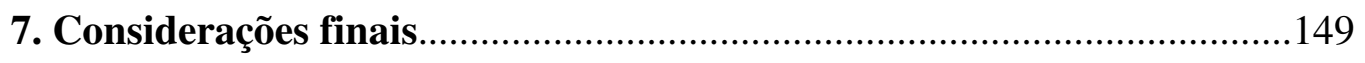

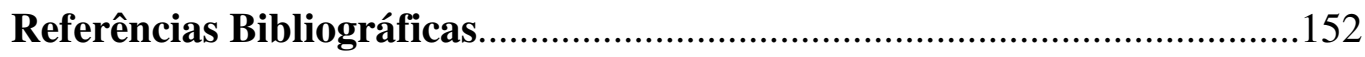

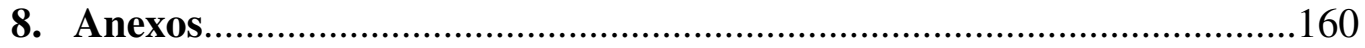

8.1 Questionário sócio-econômico............................................................160

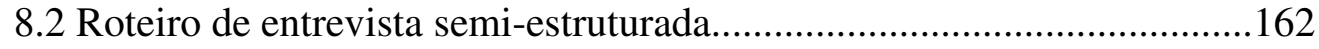

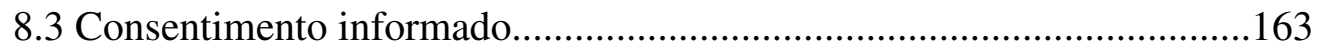

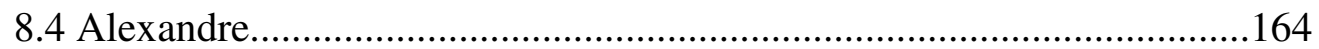

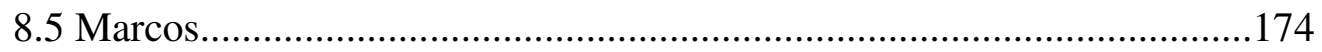

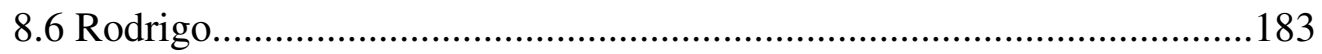

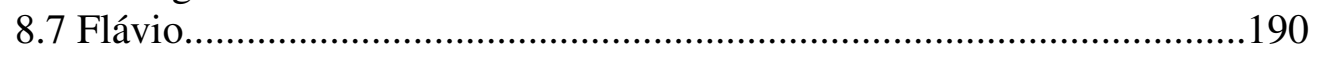

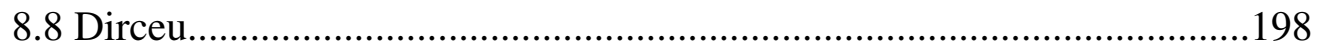

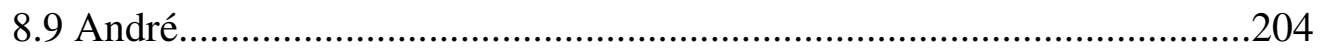

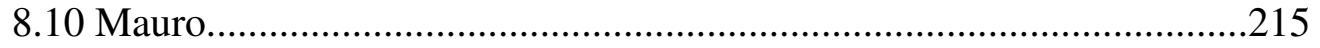

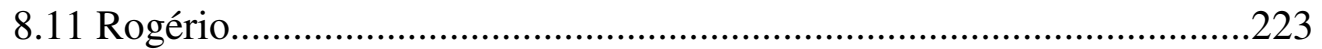

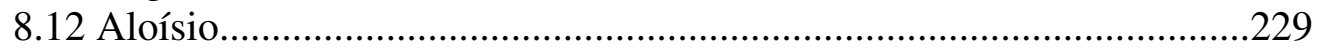

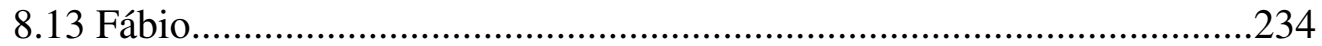




\section{RESUMO}

TOLEDO, L. C. C. A família no discurso dos membros de famílias homoparentais. São Paulo, 2008. 241 p. Tese (doutorado). Instituto de Psicologia, Universidade de São Paulo.

A união entre pessoas do mesmo sexo, um dos arranjos familiares característicos de nosso tempo, segue gerando controvérsias em vários países, participando da agenda de movimentos por direitos sexuais, interpelando autoridades religiosas e políticas, membros do judiciário e profissionais da área de saúde. Nesse ínterim, famílias homoparentais se constituem, criam e adotam filhos. A Psicologia e suas ramificações tiveram papéis destacados historicamente na configuração das condições de enunciação a respeito dessa temática. A reflexão crítica sobre a experiência dessas famílias a partir de sua perspectiva, sem reproduzir o discurso normativo, é rara.

O objeto deste estudo foi o discurso sobre a família proferido por 10 homens membros de família homoparentais residentes em Ribeirão Preto e arredores, com média de idade de 35 anos. As 10 entrevistas em profundidade foram analisadas a partir do referencial da análise de discurso e da obra de Michel Foucault, discutidas à luz da literatura do campo construcionista que pensa a sexualidade como fenômeno social.

Discutiu-se que os entrevistados referem-se de formas distintas às suas famílias de origem e às suas famílias atuais, homoparentais. Às famílias atuais foram associados sentimentos amorosos intensos, o companheirismo e a rapidez na decisão de morar juntos. Os enunciados sobre as famílias de origem foram marcados por menções à rejeição, à violência, à morte, perdas e sofrimento. Vários dos homens entrevistados mostraram-se temerosos ante a possibilidade de serem rejeitados por parentes próximos, colegas de trabalho, membros do judiciário e psicólogos em função de sua orientação sexual ou de seu pertencimento a uma família homoparental. Ao discorrerem sobre essa temática, os entrevistados construíram cenas enunciativas marcadas por uma acentuada assimetria de poderes. Diante da exposição pública de sua orientação sexual e de sua família homoparental, restaria aguardar, pedir ou torcer pelo reconhecimento e pela aceitação social. Defenderam reiteradamente a normalidade de si mesmos, de suas famílias e filhos. Todos externaram o desejo de tornarem-se pais e destacaram os sentimentos amorosos como o critério mais importante para a escolha de uma criança para adoção.

Todo discurso é uma produção cujas condições de possibilidade dependem do contexto de sua enunciação. A construção discursiva dos membros dessas famílias acerca do que seria a família homoparental está ocorrendo sob condições desfavoráveis, pois se elas ganharam visibilidade social nos últimos anos, também foram alvo de ataques e tiveram sua legitimidade e cidadania contestadas por instituições centrais para a vida cotidiana, tais como a Igreja, o poder legislativo e judiciário. Devem ser considerados, portanto, os riscos de utilizarmos termos como homoparentalidade ou gay families no âmbito dos estudos e práticas em Psicologia. Psicólogos (dentre outros profissionais de saúde) participaram da construção da imagem do homossexual como uma outra espécie, associada à doença, ao pecado e ao crime e deveriam ter cautela para não defini-las como mais uma espécie deficitária de família. 


\begin{abstract}
TOLEDO, L. C. C. The family in the speech of members of gay families. São Paulo, 2008. 241 p. Thesis (doctorship). Institute of Psychology, University of São Paulo.

Among other family arrangements of our times, same sex-couples in several countries are controversial, a theme that is part of the sexual rights movement agenda challenges religious, juridical and political authorities, and health care professionals. In the meantime, new gay families are created, take care and adopt children. Psychology had a leading role in the history of the discourse conditions on this issue. A reflexive and critical literature about these families experience in their own perspective is rare.

The aim of this study was the discourse about family constructed by 10 men that are members of gay families residing in the neighbourhood of Ribeirão Preto, a medium size city in São Paulo State interior. Ten in-depth interviews were conducted with men, average age of 35 years old. They were analyzed within the discourse analysis framework, based on Michel Foucault's work and the social constructionism literature that assumes sexuality as a social phenomenon.

It was discussed how the interviewees distinguished their families of origin from their current family. Their current families were associated to intense loving feelings, partnership and the impulsiveness in their decision to share a home. The discourses related to their family of origin were marked by mentions of rejection, violence, death losses and suffering. Several of the interviewed men were concerned and frightened by the possibility of being rejected by close relatives, co-workers, members of the judicial power and psychologists due to their sexual orientation or due to their belonging to gay families. When they mentioned this theme, they constructed narrative scenes marked by a relevant power asymmetry. If their sexual orientation and their belonging to a gay family was exposed, they would have to wait, asking or hoping for social recognition and acceptance. The interviewed also repeatedly claimed the normality of their family, children and their own. All of them have expressed the desire of being a parent. When indicating the best criteria for selecting a child for adoption, they would choose their loving feelings.

Discourse production is conditioned by and depends of the context of its' enunciation. The discursive construction by members of such families conceptualizing homoparental families is occurring under un-favorable conditions, since, despite gay families have obtained social visibility during last years, they have also been subjected to critics and have had their legitimacy and citizenship contested by important institutions of daily life, such as churches and legal and politic sphere. Finally, we ask for caution of using terms like homoparentship or gay families within psychology studies and practices, considering that psychologists (amongst other health professionals) participated in the construction of the homosexual as another human species, associated to diseases, sins and crimes. We should take care in not to define homoparental families as another non-normal and problematic family.
\end{abstract}




\section{INTRODUCÃO}

Domingo, 25 de Maio de 2008. Uma multidão aglomerava-se na Avenida Paulista para participar da 12a . Parada Gay de São Paulo. Os participantes também ocupavam trechos da Avenida Brigadeiro Luís Antônio. A multidão estendia-se por um quarteirão além da Praça Roosevelt. Mais de dez anos após a sua primeira edição paulistana, que havia reunido cerca de duas mil pessoas, a Parada novamente reunia um grande público na maior cidade do país. De acordo com Polícia Militar, 3,5 milhões de pessoas haviam comparecido à Avenida Paulista para o evento no ano anterior (HISTÓRICO, 2007). Em 2008 o número de participantes foi de 3,4 milhões (ASSOCIAÇÃO, 2003).

Ano após ano a Parada vem firmando-se como uma das grandes manifestações populares do Brasil, atraindo um público comparável ou superior ao de tradicionais festas religiosas, de shows musicais históricos ou dos grandes comícios.

O Círio de Nazaré, por exemplo, que tradicionalmente atrai milhares de católicos para uma enorme procissão pelas ruas de Belém do Pará contou com cerca de 2 milhões de participantes em 2007 (CÍRIO, 2007).

A primeira e monumental edição do Rock in Rio, realizada em 1985 na Cidade do Rock construída em Jacarepaguá, Rio de Janeiro, recebeu um público total de 1,5 milhões de espectadores (ROCK, 2008).

O comício a favor das eleições presidenciais diretas - que ficou conhecido como o Comício das Diretas Já e tornou-se um marco na história da política 
nacional - realizado no Vale do Anhangabaú em 1984, reuniu 2 milhões de manifestantes $(\mathrm{G} 1,2008)$.

Em pouco mais de uma década de existência da Parada, as pessoas que unificam sua bandeira de luta sob a sigla LGBT $^{1}$ tornaram-se capazes de reunir um grupo de manifestantes superior ao número de habitantes de cidades populosas, como Campinas (UNICAMP, 2008). Trata-se de um feito expressivo. Em um trabalho lançado antes da virada do milênio (em 1999), Richard Parker já sustentava que as culturas gays seriam "motores de mudanças” sociais que afetariam a todos:

Reorganizando as relações familiares e as concepções aceitas de parentesco (pretensas famílias ou famílias que escolhemos, legislação da parceria doméstica, benefícios ao parceiro, e assim por diante); oferecendo estratégias criativas para a organização e a prestação de serviços de base comunitária (prevenção da AIDS, sistemas de camaradagem, grupos de apoio para idosos, novos modelos de assistência hospitalar); remodelando os espaços e as economias urbanas (melhoria econômica das áreas do centro da cidade, a criação de bairros ou guetos gays, marketing baseado em identidade e associações de comerciantes como elementos fundamentais das economias pós-industriais e capitalistas); remodelando as convenções estéticas, os valores morais e os padrões aceitos...” (pág. 304, 2002)

Se o final da década de setenta e os anos oitenta foram períodos de surgimento e consolidação de uma militância homossexual ${ }^{2}$ brasileira organizada

\footnotetext{
${ }^{1}$ A sigla LGBT (que se refere a lésbicas, gays, bissexuais, travestis e transexuais) foi adotada a partir da 1.a Conferência GLBT realizada em junho de 2008 em Brasília. A mudança atendeu a uma solicitação das lésbicas, além de seguir o padrão estabelecido internacionalmente (CLAM, 2008).

2 Consideramos, com Uziel (2007), que o uso da palavra homossexual pode ser pouco preciso e insuficiente quando utilizado para descrever o que se configura como uma imensa variedade de sentimentos, desejos e práticas. Não pretendemos nos aprofundarmos no debate sobre a propriedade desse termo no presente trabalho, mas consideramos relevante afirmar que o uso do termo não designa apenas pessoas que tem práticas sexuais com outras do mesmo sexo, mas remete também "a um universo de patologia, de raízes médicas e jurídicas" (UZIEL, 2007). Se nos Estados Unidos o termo gay é utilizado com maior frequiência em trabalhos científicos, o mesmo não ocorre no Brasil. Por isso, optamos por utilizar a palavra homossexual nesse trabalho (com a exceção de quando estivermos nos referindo às Paradas Gays, ao contexto norte-americano, a citações textuais de nossos entrevistados e de pesquisadores que preferiram utilizar essa palavra).
} 
(MOSCHETA, 2004), a década de noventa e os primeiros anos do novo milênio provavelmente serão lembrados como um período de grandes manifestações, nas quais os participantes buscaram, sobretudo, o reconhecimento dos direitos dos LGBTs: união estável, adoção, transmissão de herança, dentre outros.

Raupp (2007) afirma que, do ponto de vista jurídico, são as demandas por direitos sociais, como o direito à adoção e à união estável, que têm impulsionado as discussões e avanços no que diz respeito aos LGBTs da América Latina. O mesmo não ocorre nos países europeus e nos Estados Unidos, onde os progressos jurídicos se deram a partir de debates sobre o direito à privacidade $\mathrm{e}$ ao direito a não sofrer discriminação.

Apesar dos esforços de alguns parlamentares, no entanto, o Brasil ainda não dispõe de uma legislação específica aprovada sobre o tema, o que não tem impedido a Justiça brasileira de agir, em alguns casos, em favor dos LGBTs, como veremos a seguir. Seja na luta por direitos sociais, na busca pela garantia da privacidade ou no combate à discriminação, o que se verifica é que a pressão por mudanças não se restringe ao nosso país e faz-se presente em boa parte do mundo (CASTELLS, 2000).

As resistências enfrentadas pelos homossexuais que se dispuseram a constituir famílias no Brasil, entretanto, não foram nem são desprezíveis, provindo de fontes variadas. Como foi indicado por Uziel (1999), “a opção sexual/afetiva pelo mesmo sexo já ocupou a esfera religiosa como pecado, a legal como crime e a médica como doença". 


\section{1 - A multiplicidade familiar}

Em 1956, Claude Lévi-Strauss (2003) afirmou que, após percorrer o grande repertório das sociedades humanas desde Heródoto, seria possível afirmar que a família conjugal ${ }^{3}$ é uma forma de organização muito freqüente, mesmo nas sociedades cujos hábitos sexuais e educativos diferem de modo marcante dos modelos ocidentais. Para Lévi-Strauss, após sustentarem durante cerca de meio século que as famílias do mundo moderno seriam produto da evolução humana, os antropólogos foram forçados a rever seus pontos de vista, já que a presença dessa forma de organização familiar seria identificável em quase todas as sociedades conhecidas. Entretanto, prosseguiu Strauss, sempre existiram outros arranjos familiares e esse fato bastaria para afirmar que a família conjugal não é uma necessidade universal, pois diversas sociedades mantiveram-se sem ela. Ao discorrer a respeito da diversidade de arranjos familiares conhecida pelos estudiosos do campo, Strauss (2003) afirmou:

Por mais bizarros que nos possam parecer, estes tipos de casamento ainda têm em conta a diferença dos sexos, condição essencial a nossos olhos para a fundação de uma família (embora as reivindicações dos homossexuais comecem a abrir-lhe fendas) (grifo nosso) (pág. 84).

De fato, as "fendas" mencionadas pelo autor abriram-se e ganharam visibilidade nos últimos anos, como veremos no correr deste trabalho. Strauss considerou, ainda, que seria um erro reduzir a família à sua base natural, como se ela devesse a sua existência aos instintos, à força dos laços afetivos entre 
homem e mulher ou entre pais e filhos. O que diferenciaria os homens dos animais seria que, para os primeiros, a família não poderia existir sem uma sociedade, sem outras famílias aptas a reconhecer laços de união que não os da consangüinidade e sem que se admitisse que "o processo natural de filiação não pode seguir o seu curso senão integrado no processo social da aliança”. Ou seja, a família conjugal não era um fenômeno natural, não era uma decorrência de um processo evolutivo e não devia sua existência fundamentalmente aos instintos ou ao amor entre seus membros. Suas bases estariam assentadas na aliança (o casamento), na filiação, na proibição do incesto e na troca, que definiriam a forma pelas quais os laços matrimoniais e a circulação das mulheres estabelecer-se-iam socialmente.

Roudinesco (2003) considera que a família conjugal nuclear dos dias correntes teria sido fruto do destacamento de um núcleo, formado por pai, mãe e filhos, do grande grupo familiar que anteriormente incluía outros parentes, criados, pessoas próximas e amigos. Esse processo de "destacamento" do núcleo familiar teria ocorrido na Europa entre os séculos XVI e XVII ${ }^{4}$.

\section{2 - As famílias brasileiras}

Em um estudo sobre as mudanças ocorridas nas famílias brasileiras da Colônia até início do século XXI, Samara (2002) afirmou que as famílias com

${ }^{3}$ Baseada em uniões aprovadas pela sociedade e de duração variável entre parceiros de sexos diferentes que fundariam um lar, procriariam e educariam sua prole. 
poucos integrantes já predominavam no Brasil desde os tempos da Colônia, apesar do grande contingente de famílias extensas (que incluíam escravos e dependentes de tipos variados) que residiam principalmente no Nordeste. No Brasil colonial o pátrio poder era "a pedra angular da família e emanava do matrimônio", sendo corroborado pelo Estado. Entretanto, mudanças econômicas propiciariam o ingresso das mulheres no mercado de trabalho, gerando mudanças sociais que repercutiriam na organização das famílias brasileiras. A descoberta das minas de ouro na década de 1690 deslocou o eixo econômico do Nordeste, atraindo pessoas para centros urbanos nos quais as mulheres passaram a exercer atividades profissionais fora do âmbito doméstico com mais frequiência. A mesma autora afirma, ainda, que não era incomum encontrar famílias chefiadas por mulheres solteiras nos centros mais desenvolvidos.

No século XVII as brasileiras que viviam no meio urbano trabalhavam ocupando postos de trabalho abertos pela falta de escravos e pela migração masculina. A segunda metade do século XIX teria sido marcada pela abertura de vagas na indústria nacional nascente e na burocracia estatal. Parte dos novos postos de trabalho foram ocupados por mulheres. Ainda assim, o Estado brasileiro prosseguiu ratificando a supremacia masculina, como se observa no Código Civil de 1916 (SAMARA, 2002).

\footnotetext{
${ }^{4}$ Roudinesco (2003) faz a ressalva de que essa estrutura nuclear de base já podia ser encontrada na Europa da Idade Média, muito antes, portanto, de ter se tornado o modelo dominante da época moderna.
} 
Em 1836 as famílias nucleares predominavam na cidade de São Paulo, em detrimento das famílias extensas, que representavam $26 \%$ dos domicílios. Mas os dados disponíveis também indicam que, já na primeira metade do século XIX, as famílias pobres eram majoritariamente chefiadas por mulheres (SAMARA, 2002).

Berquó (1998) afirma que o "caráter nuclear da família”, ou seja, o casal com ou sem filhos, predominava no Brasil do final do século passado, mas o número de casais com filhos apresentava uma tendência declinante consistente no país quando comparado aos dados de décadas anteriores. Na década de oitenta cresceram significativamente as uniões conjugais sem vínculos legais e os arranjos monoparentais ${ }^{5}$. A incidência desses últimos havia praticamente dobrado nas décadas anteriores.

Segundo dados do último censo do IBGE $^{6}$ (BRASIL, 2001), que ainda não considerava os números da Contagem Populacional de 2007, pouco mais da metade de nossas famílias $(53,3 \%)$ eram nucleares. Entretanto, mais de 23 milhões de famílias brasileiras (46,7\% do total) tinham composições diversas; eram casais sem filhos, mulheres sem cônjuge com filhos, unipessoais ou de "outros tipos", nos termos do relatório.

Em 2007, o IBGE (CONTAGEM, 2007) divulgou os primeiros dados de um trabalho que indicava que $0,2 \%$ da população ${ }^{7}$ brasileira havia declarado espontaneamente ter companheiros do mesmo sexo atuando como chefes de casa

\footnotetext{
${ }^{5}$ Pai com filhos ou mãe com filhos, contando ou não com outros parentes na mesma casa.

${ }^{6}$ Instituto Brasileiro de Geografia e Estatística.

${ }^{7}$ Esse número é, provavelmente, subdimensionado.
} 
nos 5.435 municípios pesquisados. Foi a primeira vez na história do país que a Contagem da População do IBGE divulgou dados sobre casais homossexuais que vivem juntos. Mais do que a divulgação de um dado estatístico (relevante, sem dúvida), o relatório fornecido pelo IBGE constituiu-se como um marco importante: o reconhecimento de uma parte da população que, até então, permanecia invisível nas estatísticas populacionais oficiais.

\section{3 - A mudança em outros países}

Baseando-se em uma ampla pesquisa, na qual trabalhou com dados populacionais relativos a diversos países ${ }^{8}$, Castells (2000) afirmou que nas últimas décadas do século XX, nos Estados Unidos e em parte da Europa, havia indicativos consistentes de que estava em curso um declínio numérico progressivo e consistente do número de famílias nucleares. Segundo o autor, vários fatores contribuiriam para esse declínio, dentre eles: as mudanças no mercado de trabalho global e a abertura de oportunidades profissionais para as mulheres de classe média (que passaram a trabalhar fora de casa e a ganhar salários expressivos), os avanços tecnológicos que permitiram um controle maior sobre a gravidez e a reprodução humanas (aumentando a confiabilidade do planejamento familiar) e o advento do movimento feminista (que questionaria, dentre outros, a heterossexualidade como norma).

A esse respeito, Castells (2000) afirmou que:

\footnotetext{
${ }^{8}$ Estados Unidos, México, Egito, Canadá, Inglaterra, França, Itália, dentre outros.
} 
Se as tendências atuais continuarem a se expandir por todo o mundo, e asseguro que continuarão, as famílias, tal como as conhecemos $^{9}$, tornar-se-ão uma relíquia histórica no futuro não muito distante. $\mathrm{E}$ a estrutura de nossas vidas se transformará à medida que sentirmos, às vezes dolorosamente, os abalos dessa transformação (pág. 191)”.

Mais do que o declínio de um tipo de organização familiar em detrimento de outros arranjos, Castells sustentou que os países desenvolvidos estariam assistindo ao que ele chamou de "crise da família patriarcal".

O patriarcalismo seria uma estrutura caracterizada "pela autoridade, imposta institucionalmente, do homem sobre a mulher e filhos no âmbito familiar" (CASTELLS, 2000). Para ele, os países desenvolvidos e os centros desenvolvidos dos países periféricos estariam caminhando para uma mudança de grandes proporções na distribuição de poderes nas relações familiares. O mesmo fenômeno, prosseguiu Castells, também se verificaria em áreas mais urbanizadas dos países em desenvolvimento (como o Brasil) e a tendência seria a de que, paulatinamente, o mesmo também viesse a ocorrer nas áreas rurais.

Berquó (1998) também mencionou a ocorrência de transformações nas atribuições dos cônjuges nos arranjos domésticos e o surgimento de novos padrões de relacionamento entre os parentes no fim do século passado no Brasil. A autora considerou que as famílias brasileiras estariam tornando-se mais igualitárias e menos hierárquicas. Para ela, essa tendência seria mais marcante nas camadas médias urbanas e tenderia a estender-se progressivamente às camadas populares.

\footnotetext{
${ }^{9}$ Castells se refere às famílias nucleares nas quais o poder paterno impera.
} 
Entretanto, em meio a esse cenário de mudanças na configuração e na distribuição de poderes no âmbito familiar, e mesmo que "há mais de um século, pelo menos se descrevam as transformações da família, retirando-a da imobilidade metafísica ou biológica”, Sylvia Leser de Mello (2002) considera que:

Apesar disso, as idéias de uma sexualidade natural, de um parentesco natural e de uma família natural fazem parte de nossa imaginação e estão, há longo tempo, fixadas pela socialização e pela educação familiares, que se apresentam como definitivas formas históricas... (pág. 17).

Para a autora, as idéias de uma sexualidade, de um parentesco e de uma família naturais encontram-se fartamente disseminadas na sociedade. Essa naturalização da família nuclear não é um fenômeno recente e tampouco restrito a um país específico.

À medida que era alçada à condição de estrutura familiar hegemônica nos países desenvolvidos e nos centros desenvolvidos de países periféricos, a família nuclear tornou-se uma referência normativa, um modelo a ser seguido e incentivado por médicos, juristas, psicólogos e outros profissionais (COSTA, 1999; PONCIANO \& FEREZ-CARNEIRO, 2003).

Uziel (2007) afirma, por exemplo, que apesar do Estatuto da Criança e do Adolescente brasileiro não restringir a noção de família à existência dos dois sexos como casal parental, considerando suficiente a existência de um dos dois e de uma prole, os operadores do direito brasileiro seguem referindo-se a casais quando discorrem sobre requerentes à adoção. A idéia de uma família natural, formada por pai, mãe e filhos, prossegue como uma referência 
marcante, alçada à condição de arranjo ideal (em detrimento dos demais) e não como uma possibilidade dentre outras.

\section{4 - Sexualidade e família}

Como mencionou Mello (2002), as idéias de um parentesco e de uma família naturais, há muito tempo fixadas pela socialização e a educação, fizeram-se acompanhar por um modelo de sexualidade natural, sinônimo de heterossexualidade, de casal parental e de monogamia. Essa concepção de sexualidade viria a ser severamente questionada por vários autores, principalmente após o recrudescimento do movimento feminista, dando margem a um debate de grandes proporções.

Parker (2000) identificou um aumento significativo no número de pesquisas acadêmicas sobre a sexualidade a partir da década de oitenta em áreas como a antropologia social e cultural. Vários desses trabalhos foram escritos por autores que partilhavam de noções que Parker chamou genericamente de "as abordagens sobre a construção social da sexualidade" (VANCE, 1991; MOORE, 1997; WEEKS, 2001). A teoria da construção social sustenta, em geral, que a sexualidade humana é construída de formas diferentes através das culturas e do tempo.

Vance (1991) e Parker (2000) compararam aspectos dessa teoria com outro modelo: o da influência cultural. Nele, a sexualidade era compreendida como um estado universal e imutável, sendo apenas "mediado" com maior ou 
menor intensidade pelo contexto cultural. Vance (1991) considera que o modelo de influência cultural teria sido importante para os trabalhos antropológicos sobre sexualidade de 1920 até 1990. A esse respeito, Parker afirma que:

"Ainda que esse modelo (da influência cultural) admita que exista alguma variação transcultural na expressão da sexualidade, a sua manifestação e o seu suposto impulso biológico, bem como a sua função reprodutiva" foram vistos e descritos como universais (Parker, 2000. pág. 44).

Vance (apud PARKER, 2000) salienta que a categoria "construção social" teria conotações variadas entre os pesquisadores do campo da sexualidade, mas que, de forma geral, os trabalhos dos autores construcionistas questionaram o que ela chamou de noções essencialistas sobre a sexualidade. Entre estes últimos imperaria a crença de que haveria algo na natureza humana, como um instinto ou uma energia sexual, que seria responsável pela condução de nossas ações. A sexualidade seria compreendida, então, como um mecanismo fisiológico ou como a manifestação de uma pulsão psíquica que deveria ser extravasada (HEILBORN \& BRANDÃO, 1999).

A definição de um conceito - o de gênero - foi fundamental para sustentar a argumentação daqueles que eram contrários aos essencialistas, como veremos a seguir. 


\section{5 - O gênero}

Segundo Scott (1990), o interesse por definir com rigor o conceito de gênero e utilizá-lo politicamente emergiu no final do século XX como parte da tentativa das feministas de "reivindicar um certo terreno de definição" e para apontar a inadequação das teorias a respeito das persistentes desigualdades entre homens e mulheres.

Para Weeks (2001), o conceito de gênero diria respeito às diferenciações sociais entre homens e mulheres. Esse autor considerava que a palavra "sexo" deveria ser usada de forma precisa para descrever "diferenças anatômicas básicas, internas e externas ao corpo". Já a palavra "sexualidade" seria útil para descrever a série de "crenças, comportamentos, relações e identidades socialmente construídas e historicamente modeladas..."

Moore (1997) criticava incisivamente o uso da palavra "natural" quando a imprensa ou o meio acadêmico abordavam questões relativas ao sexo apresentando as "diferenças estabelecidas entre homens e mulheres na vida social como se fossem originárias da biologia". Para a autora, qualquer descrição sobre o sexo (mesmo que essa se referisse ao sexo biológico) seria inevitavelmente uma construção cultural provisória e também uma descrição de gênero, já que não seria possível fazê-lo sem recorrer a discursos característicos de uma determinada época, grupo e sociedade.

Convém mencionar que as feministas não se encontravam solitárias em seu trabalho de desconstrução dos discursos essencialistas a respeito da 
(natureza da) sexualidade ou de qualquer concepção naturalizadora da família. Os movimentos homossexuais, organizados principalmente após a década de $70^{10}$, levaram adiante e aprofundaram alguns dos debates iniciados por elas. Esses movimentos seguiram ganhando força em vários países reivindicando direitos e questionando o que Castells (2000) chamou de "heterossexualidade compulsória”.

Os questionamentos e críticas à heterossexualidade compulsória não são uma inovação histórica, considera Castells, mas o impacto social dessas contestações seria um fenômeno característico de nossa época. Parte desse impacto tem resultado do crescimento dos movimentos homossexuais ao redor do mundo, bem como das reivindicações e pressões políticas exercidas pelos mesmos.

\section{6 - Luta e reconhecimento}

A Revolta de Stonewall, ocorrida em Nova Iorque no fim de junho de 1969 é considerada um marco ${ }^{11}$, o ponto de partida no movimento gay ${ }^{12}$ norte-americano, que cresceria em um ritmo vertiginoso nos primeiros anos da década de setenta. Durante três dias, centenas de homossexuais reagiram à violência das batidas policiais que aconteciam no bar The Stonewall,

\footnotetext{
${ }^{10}$ É importante mencionar que já existiam subculturas sexuais amplas no Brasil e em outros países desde, pelo menos, o início do século XX. Essas subculturas urbanas apenas tornaram-se mais visíveis nas últimas décadas do milênio (PARKER, 2002)

${ }^{11}$ Nos Estados Unidos e em outros países, incluindo o Brasil.

${ }^{12}$ Como mencionamos anteriormente, os americanos optaram por utilizar a palavra gay em detrimento de qualquer outra palavra que pudesse remeter à nomenclatura médica ou jurídica (ROUDINESCO, 2003).
} 
freqüentado por gays, lésbicas e travestis. As notícias da revolta correram o país e inspiraram ações de resistência e afirmação. Em 1960 haviam cinqüenta organizações gays nos Estados Unidos, trezes anos mais tarde o número havia crescido para oitocentas (CASTELLS, 2000).

No Brasil, segundo Parker (2002), o movimento homossexual começou a organizar-se no final da década de setenta. $\mathrm{O}$ mesmo autor alerta que seria um erro vê-lo como uma "importação" (termo de Parker) do que aconteceu nos Estados Unidos. O surgimento da Aids, entre o início e meados da década de oitenta, foi um aspecto fundamental no processo de mobilização social e política da comunidade homossexual brasileira que já vinha desenvolvendo-se principalmente nos centros urbanos. Vários grupos surgiram na esteira do fenômeno da $\operatorname{Aids}^{13}$ e, neles, brasileiros assumidamente homossexuais desempenhavam papéis de liderança. Pela primeira vez "atividades formais destinadas a servir a comunidade homossexual foram fundadas e implementadas" no país (PARKER, 2002).

O autor considera, ainda, que o nascimento do movimento brasileiro é inseparável do contexto social da abertura política. O avanço do processo de redemocratização foi acompanhado pelas iniciativas de grupos e de "uma política de homossexualidade conscientemente organizada em torno de uma noção de identidade gay passou a ser uma força crescente" (PARKER, 2002).

No que se refere especificamente às famílias homoparentais, Roudinesco (2003) afirma que elas teriam se tornado um fato mais visível 
socialmente em todo o mundo a partir do momento em que seus membros puseram-se a lutar por seus direitos em vários países.

Auerbach e Silverstein (apud UZIEL, 2007) dividiram em fases o processo de afirmação da parentalidade gay. Na primeira delas, os filhos seriam frutos de relações heterossexuais anteriores. Em seguida, as lésbicas das décadas de 70 e 80 decidiram ter filhos. Nos anos seguintes, décadas de 80 e 90, os gays seguiram o exemplo das lésbicas. Essas famílias enfrentaram (e seguem enfrentando) uma oposição aguerrida às suas demandas e à sua existência.

\section{7 - As Considerações da Igreja Católica e outras vozes religiosas}

Instituições importantes, como a cúpula da Igreja Católica, têm reagido com veemência à demanda por reconhecimento estatal das uniões homoparentais, inclusive no Brasil.

Mello (2005) considera que, com algumas poucas exceções, a Igreja Católica brasileira tem posicionado-se historicamente a respeito da conjugalidade e da parentalidade homossexuais de forma condenatória e excludente. Para sustentar seus argumentos, Mello citou algumas passagens de entrevistas de representantes importantes da Igreja brasileira concedidas durante a década de noventa. Mencionaremos duas delas:

\footnotetext{
${ }^{13}$ O Grupo Somos e o Lambda em São Paulo, o Triângulo Rosa no Rio de Janeiro, o Grupo Gay da Bahia, dentre outros surgiram nesse período.
} 
A união entre homossexuais é uma grande bobagem, uma besteira e vai trazer um grande prejuízo para o Brasil. Isto é uma espécie de queda do sentido da vida e da pessoa humana. O homossexual é gente que deve ser tratada como pessoa doente: ele não está dentro de sua configuração humana (D. Aloizio Lorscheider, Arcebispo de Aparecida, em matéria publicada no Diário de Fortaleza, em 20 de Dezembro de 1996). (apud MELLO, 2005).

A união de homossexuais é uma aberração. Um cachorro pode até cheirar o outro do mesmo sexo, mas eles não tem relação. Sem querer ofender os cachorros, acho que isso é uma cachorrada. Esta é a opinião de Deus e da Igreja (D. Evaldo Amaral, Arcebispo de Maceió, em matéria publicada em $O$ Jornal, de Maceió, em 27 de junho de 1997) (apud MELLO, 2005).

Um exemplo internacional da magnitude dessa reação da hierarquia católica (cuja relevância justificaria, por si, estudos aprofundados por parte de outros pesquisadores) pode ser encontrado no banco de dados do Vaticano na internet. Em junho de 2003, um documento gestado em Roma e intitulado Considerações sobre os projetos de reconhecimento legal das uniões entre pessoas homossexuais, assinado pelo (então Cardeal Prefeito) Joseph Ratzinger e pelo Arcebispo Titular Ângelo Amato, não deixava dúvidas sobre o posicionamento e as preocupações da cúpula católica com o tema desde a sua introdução:

Diversas questões relativas à homossexualidade foram recentemente tratadas várias vezes pelo Santo Padre João Paulo II e pelos competentes Dicastérios da Santa Sé... Trata-se, com efeito, de um fenômeno moral e social preocupante, inclusive nos países onde ainda não se tornou relevante sob o ponto de vista do ordenamento jurídico. A preocupação é, todavia, maior nos países que já concederam ou se propõem conceder reconhecimento legal às uniões homossexuais, alargando-o, em certos casos, mesmo à habilitação para adotar filhos. As presentes considerações não contêm elementos doutrinais novos; entendem apenas recordar os pontos essenciais sobre o referido problema e fornecer algumas argumentações de caráter racional, que possam ajudar os Bispos a formular intervenções mais específicas, de acordo com as situações particulares das diferentes regiões do mundo: intervenções destinadas a proteger e promover a dignidade do matrimônio, fundamento da família, e a solidez da sociedade, de que 
essa instituição é parte constitutiva. Têm ainda por fim iluminar a atividade dos políticos católicos, a quem se indicam as linhas de comportamento coerentes com a consciência cristã, quando tiverem de se confrontar com projetos de lei relativos a este problema. Tratandose de uma matéria que diz respeito à lei moral natural, as seguintes argumentações são propostas não só aos crentes, mas a todos os que estão empenhados na promoção e defesa do bem comum da sociedade (CONGREGAÇÃO, 2003).

Desde o início os autores afirmavam se tratar de um assunto de grande importância, um "problema" "preocupante" que envolvia questões políticas, morais, religiosas e sociais. O texto convocava os interessados em promover a dignidade do matrimônio, a família e a solidez da sociedade (que, a julgar pela introdução, encontravam-se em perigo), a posicionarem-se contra quaisquer projetos de lei relacionados ao tema.

$\mathrm{Na}$ segunda parte, intitulada Atitudes perante o problema das uniões homossexuais, os autores indicavam posicionamentos que os católicos deveriam adotar diante do "problema", sugerindo os riscos que o mesmo poderia acarretar para o "tecido da moral pública" e para a educação dos jovens. Ao final, os autores afirmavam, de um modo um tanto sombrio, que legitimar as uniões homossexuais seria o mesmo que aprovar ou legalizar "o mal".

São úteis, portanto, intervenções discretas e prudentes, cujo conteúdo poderia ser, por exemplo, o seguinte: desmascarar o uso instrumental ou ideológico que se possa fazer da dita tolerância (com os homossexuais); afirmar com clareza o caráter imoral desse tipo de união; advertir o Estado para a necessidade de conter o fenômeno dentro de limites que não ponham em perigo o tecido da moral pública e que, sobretudo, não exponham as jovens gerações a uma visão errada da sexualidade e do matrimônio, que os privaria das defesas necessárias e, ao mesmo tempo, contribuiria para difundir o próprio fenômeno. Àqueles que, em nome dessa tolerância, entendessem chegar à legitimação de específicos direitos para as pessoas homossexuais conviventes, há que lembrar que a tolerância do mal é 
muito diferente da aprovação ou legalização do mal (CONGREGAÇÃO, 2003).

O texto prosseguia desaprovando enfaticamente o comportamento

homossexual e o reconhecimento das uniões. As considerações de Ratzinger e

Amato foram ratificadas pelo Sumo Pontífice, João Paulo II, que mandou publicá-las:

A Igreja ensina que o respeito para com as pessoas homossexuais não pode levar, de modo nenhum, à aprovação do comportamento homossexual ou ao reconhecimento legal das uniões homossexuais. $\mathrm{O}$ bem comum exige que as leis reconheçam, favoreçam e protejam a união matrimonial como base da família, célula primária da sociedade. Reconhecer legalmente as uniões homossexuais ou equipará-las ao matrimônio, significaria, não só aprovar um comportamento errado, com a consequência de convertê-lo num modelo para a sociedade atual, mas também ofuscar valores fundamentais que fazem parte do patrimônio comum da humanidade. A Igreja não pode abdicar de defender tais valores, para o bem dos homens e de toda a sociedade. (CONGREGAÇÃO, 2003).

No ano seguinte à publicação das Considerações de Ratzinger e Amato (2003), a Parada Gay paulista, que já era um dos maiores eventos do tipo no mundo, contando com 1,8 milhões de participantes, teve como lema a frase “Temos família e orgulho” (HISTÓRICO, 2007). Os organizadores buscavam chamar a atenção para as questões relacionadas às famílias homoparentais ${ }^{14}$, como a luta pelos direitos à adoção, à união estável, à transmissão de bens, dentre outras.

\footnotetext{
${ }^{14}$ Termo cunhado na França em meados da década de noventa por membros da APGL, uma associação de pais e mães (e futuros pais e mães) homossexuais e lésbicas. Foi incorporado posteriormente aos trabalhos de diversos pesquisadores brasileiros, por isso optamos por utiliza-lo, apesar de também ter se tornado alvo de críticas por unir em um mesmo conceito, e de forma aparentemente natural, dois temas distintos e não necessariamente relacionáveis: família e sexualidade (UZIEL, MELLO \& GROSSI, 2006 \& UZIEL, 2007). Como essa denominação foi utilizada por seus criadores tanto para designar casais com filhos quanto os "futuros" pais, optamos por considerar todos entrevistados dessa pesquisa, fossem eles pais na atualidade ou não, como membros de famílias homoparentais.
} 
Em 2006, o Vaticano organizou uma série de conferências ao redor do mundo para divulgar a sua posição e referendar o que já havia sido exposto nas Considerações... de 2003 (FOLHA, 2006).

Convém mencionar que a Igreja Católica não se encontra solitária nessa cruzada, outras ordens religiosas também reagiram de forma vigorosa condenando as uniões homossexuais (NATIVIDADE \& LOPES, 2007).

Natividade (2008) afirma que as religiões cristãs têm historicamente manifestado-se de forma contrária às políticas de direitos LGBT. O mesmo autor sustenta que grupos religiosos brasileiros não têm apenas se oposto sistematicamente em relação ao reconhecimento e à visibilidade das minorias sexuais, como tem adotado a estratégia de dificultar a tramitação de projetos de leis que garantiriam direitos aos LGBTs (tais como o Projeto que criminalizaria a homofobia no país).

Na cena pública, o recente debate sobre a criminalização da homofobia, decorrente da tramitação do PLC-122/2006 no Senado Federal, coloca em evidência que a atuação política contrária aos direitos das populações não-heterossexuais têm ampla capilaridade. Mídia religiosa, entidades ligadas a trabalhos de reversão da homossexualidade, pastores e outros líderes religiosos, juristas e uma ampla gama de especialistas compareceram ao espaço público defendendo a liberdade de crença e expressão e o direito de "pregar contra o homossexualismo". No âmbito dessa controvérsia, a lei em questão é referida como "mordaça gay", considerada um artifício do movimento homossexual para impor seus interesses, implantar uma "ditadura gay" e perseguir religiosos. A expansão dos direitos de gays e lésbicas é percebida como violação dos direitos de pessoas "normais".

Em outubro de 2007, a audiência pública do Senado Federal, convocada pela Comissão de Direitos Humanos e Legislação Participativa, foi palco do enfrentamento entre representantes dos direitos humanos e religiosos conservadores. Os primeiros defendiam a aprovação do projeto, alertando contra a influência do fundamentalismo religioso na obstrução dos direitos GLBT. Em 
contrapartida, parlamentares e representantes de entidades religiosas sustentaram que acima desses direitos estava a "Palavra de Deus" e a Bíblia (págs. 3 e 4, NATIVIDADE, 2008).

O autor considera que membros de instituições como a Igreja Universal do Reino de Deus, A Igreja Metodista do Brasil, A Assembléia de Deus e outras teriam adotado um posicionamento coletivo contrário a projetos como o PLC122, incitando seus membros e fiéis a reagirem vigorosamente, realizando passeatas, enviando e-mails e abaixo-assinados a parlamentares, orando e fazendo jejuns. Rivais em outros aspectos, várias instituições religiosas parecem ter encontrado no combate à luta por direitos LGBT uma bandeira em comum.

\section{8 - A luta surte efeitos}

Apesar do escândalo e da reação contrária vigorosa, a luta das famílias homoparentais vem sendo paulatinamente recompensada. Holanda, Espanha, Bélgica e Canadá são exemplos de nações que reconhecem a possibilidade de casamento civil entre parceiros do mesmo sexo (UZIEL, MELLO, GROSSI, 2006). Em 2006, a Bélgica tornou-se o sexto país do mundo a estabelecer uma legislação específica que permite a adoção por parte de casais homoparentais. Anteriormente, Espanha, Suécia, Canadá, Reino Unido e África do Sul já haviam criado suas leis sobre o tema (FOLHA, 2006).

Na América do Sul, a Colômbia foi o primeiro país, e o único até o presente momento, a conceder direitos plenos aos casais homoparentais (FOLHA, 2007). 
Por outro lado, na maior parte dos países muçulmanos ser homossexual é crime passível de punição com pena de prisão ou de morte (DIMENSTEIN, 2003).

Raupp (2008) afirma que não existem ordenamentos jurídicos na América Latina que criminalizem práticas sexuais homossexuais, exceto em casos específicos (como, por exemplo, em estabelecimentos militares). Além disso, as leis de boa parte dos países da região prevêem sanções para aqueles que praticarem atos discriminatórios contra expressões da diversidade sexual. No Brasil, entretanto, como afirmamos anteriormente, não dispomos de uma legislação específica sobre a união civil entre homossexuais.

Os homossexuais nunca chegaram a ser definidos como criminosos pelo Código Penal Brasileiro, como ocorreu nos Estados Unidos e em países europeus. O fato de não serem considerados criminosos aos olhos da Lei, porém, não os eximiu de serem tratados como socialmente desviantes ou criminosos pela sociedade brasileira (FRY, 1982).

No que se refere ao âmbito legislativo, a deputada federal Marta Suplicy, em 1995, apresentou à Câmara dos Deputados o Projeto de Lei 1.151 que versava sobre o tema da união civil entre pessoas do mesmo sexo. O texto do projeto propunha em seu primeiro artigo que ficaria "assegurado a duas pessoas do mesmo sexo o reconhecimento de sua união civil, visando à proteção dos direitos à propriedade". Dentre os parlamentares que votaram contra o Projeto na Comissão Especial da Câmara dos Deputados, três tiveram uma atuação destacada nos debates a respeito da homoparentalidade: Salvador 
Zimbaldi (PSDB-SP) e Severino Cavalcanti (PPB-PE), ligados à Igreja Católica, e Philemon Rodrigues (PTB-MG), vinculado a bases evangélicas (MELLO, 2005). Os argumentos utilizados por esses deputados assentavam-se sobre dois eixos principais: a incompatibilidade entre essas famílias e a concepção religiosa de família e a idéia de que essas seriam famílias antinaturais. No lado oposto, os deputados favoráveis ao Projeto argumentaram que o amparo legal às uniões homossexuais seria uma questão de cidadania e direitos humanos, que visaria a garantir o direito à liberdade de orientação sexual e a garantia de direitos civis (MELLO, 2005). Treze anos após a sua apresentação, o projeto continua em tramitação.

Por meio de um outro Projeto de Lei, o 5.252, o deputado Roberto Jefferson propôs que se regulamentasse a permissão da adoção por parte de casais homoparentais (PROPOSTAS, 2003). O projeto foi arquivado. Outros deputados apresentaram propostas contrárias às que Suplicy e Jefferson defendiam, como veremos adiante, mas eles também não obtiveram êxito.

A falta de um dispositivo legal específico não tem impedido que os tribunais brasileiros concedam decisões favoráveis a essas famílias em processos sobre adoção de crianças, garantia de direitos de herança, partilha de patrimônio em caso de separação e de necessidade de assistência médica. As decisões favoráveis criaram jurisprudência ${ }^{15}$, abrindo precedentes para que outras decisões semelhantes possam ser tomadas por juízes em processos futuros. 
Em Outubro de 2006 um casal de homens de Catanduva, interior de São Paulo, obteve na Justiça o direito à guarda definitiva de uma criança. Foi o primeiro caso em que a Justiça concedeu ganho de causa a um casal homoparental masculino no Estado de São Paulo (FOLHA, 2006). Anteriormente, dois casais de lésbicas, um de Bagé e outro do Rio de Janeiro, também haviam obtido sucesso em ações semelhantes (G1, 2006). Em Dezembro do mesmo ano, mais um casal, residente em Ribeirão Preto, cidade do interior paulista, obteve a guarda provisória de duas crianças (O GLOBO, 2007).

O Judiciário brasileiro antecipou-se ao Legislativo, premido pela pressão popular $^{16}$ e pela necessidade de tomar decisões a respeito de famílias que já existiam, independentemente do que seria estabelecido pelos legisladores a respeito de sua legitimidade. Se os legisladores brasileiros seguem tímidos ou omissos no trato da questão, o Judiciário tem se mostrado capaz (ao menos em alguns casos) de responder às mudanças sociais em curso. O que se verifica é que as decisões favoráveis às demandas dos LGBTs têm se tornado paulatinamente mais freqüentes no país.

\footnotetext{
15 Diniz (1008) refere-se à jurisprudência como um conjunto de decisões uniformes de juízes de tribunais superiores sobre uma dada matéria.

${ }^{16}$ Parker (2002) afirma que a política de identidade gay é uma das forças mais poderosas do mundo contemporâneo.
} 


\section{9 - Dos tratamentos médicos da homossexualidade ao debate no} campo psicanalítico

Weeks (2001) afirma que os termos homossexualidade e heterossexualidade foram utilizados pela primeira vez ("aparentemente" nas palavras do autor) pelo escritor austro-húngaro Karl Kertbeny, em 1869. O interesse de Kertbeny teria sido o de colocar na pauta política da Alemanha a revogação das leis anti-sodomitas, então vigentes. Weeks considera que outros estudiosos pioneiros, como Krafft-Ebing, Magnus Hirschfeld e Havelock Ellis, adotaram o termo de Kertbeny, transformando-o em algo mais do que uma "variante benigna da normalidade", como desejava seu criador. Estabelecia-se dessa forma a transformação do sodomita em homossexual, o que não se deu sem grandes implicações.

Para Foucault (2001) os sodomitas eram vistos na Europa, até aquele momento (antes de 1870), como aberrações temporárias ou como "reincidentes". Os homossexuais, ao contrário dos sodomitas, seriam descritos a partir de então como pessoas com uma essência sexual inata significativamente diferente da dos heterossexuais. Foucault afirmou em 1976, ano de lançamento do primeiro volume sobre a História da Sexualidade, que com o surgimento da palavra homossexual nascia uma outra "espécie".

A criação do termo homossexualidade, e o uso que dele foi feito, transformaria os sodomitas (que eram vistos como pecadores ou criminosos eventuais) em "hermafroditas da alma", em personagens com "um passado, 
uma história, uma infância, um caráter, uma forma de vida". Pois "nada daquilo que ele (homossexual) é... escapa à sua sexualidade" (FOUCAULT, 2001).

Parker (2002) considera que a homossexualidade deixou de ser compreendida como um comportamento sexual, para tornar-se uma classe diferenciada de pessoas que teriam um modo "diferente de ser no mundo". Foucault (1998) afirma que por volta de 1870 os psiquiatras teriam começado a constituir a homossexualidade como um objeto de análise médica.

Graña (1998), que escreveu sobre os tratamentos dispensados aos homossexuais pela Medicina ocidental, considera a história das propostas médicas para suprimir a homossexualidade como um subproduto da intolerância social "com a qual os homossexuais convivem dramaticamente pelo menos desde o advento do cristianismo".

Kraft-Ebing, psiquiatra alemão de formação católica, afirmou peremptoriamente no clássico Psychopatia Sexualis, de 1886, que a homossexualidade e o travestismo decorriam da degeneração do sistema nervoso central ou eram indicativos de doenças cerebrais hereditárias. Nos Estados Unidos, prossegue Graña (1998), as idéias de Ebing foram bem recebidas e, eventualmente radicalizadas. Alguns defendiam que as perversões de vários tipos (como a sodomia, pederastia, bestialidade, masturbação compulsiva, dentre outras) deveriam ser consideradas não apenas doenças, mas também crimes e aos seus perpetradores caberiam penas como a proibição da procriar ou, simplesmente, a castração. 
Havelock Ellis, sexólogo britânico, questionou a teoria degenerativa em Sexual Inversion, de 1897, demonstrando que a castração era inútil como método terapêutico e que essa acabava por desencadear crises depressivas e estados paranóides. Não obstante, a castração foi levada adiante nos anos seguintes em parte dos Estados Unidos (Graña, 1998).

No século passado várias outras terapêuticas surgiram com o objetivo explícito de curar a homosexualidade ou o travestismo. Em 1937, Owensby criou e difundiu a terapia dos choques convulsivos induzidos. Ele acreditava que os episódios convulsivos seriam eficazes no combate ao desejo homossexual (Graña, 1998).

Na década de quarenta as lobotomias pré-frontais e os tratamentos com hormônios foram recomendados em larga escala, com algumas vítimas fatais. Cabe ressaltar, que, após a lobotomia, ao contrário do que desejavam os médicos, o desejo homossexual aumentava, segundo os relatórios de hospitais como o Pilgrim de Nova Iorque (GRAÑA, 1998).

Do outro lado do Atlântico, na Tchecoslováquia, Srnec e Freund procediam ao que chamaram de terapia da aversão, um método que fez sucesso durante alguns anos. Este consistia em inocular substâncias que causavam um intenso mal estar físico, acompanhado de náuseas e vômitos. Enquanto o desconforto se estabelecia, os médicos instruíam os "pacientes" a assistirem a filmes e slides estrelados por homens nus. O procedimento era repetido sem grandes intervalos até seis vezes com a mesma pessoa. À noite, após o suplício, os "pacientes" recebiam injeções de testosterona enquanto 
assistiam a filmes com mulheres consideradas desejáveis sexualmente. Os pacientes considerados "curados" pelos criadores do método "reincidiram em poucos meses" (GRAÑA, 1998).

Destoando de vários de seus contemporâneos médicos, Freud não considerava desejável criar uma terapêutica capaz de transformar homossexuais em heterossexuais. Roudinesco e Plon (1998) consideram que sua postura e seus escritos sobre o tema constituem-se como rompimentos com a tradição psiquiátrica de sua época, que descrevia os homossexuais como tarados, degenerados ou malditos.

Em 1905, nos clássicos Três ensaios sobre a teoria da sexualidade, Freud compreendia a homossexualidade como uma das derivações possíveis da bissexualidade humana (Freud, 1980). Por pensar desse modo, seu interesse voltou-se para o que chamou de homossexualidade latente dos heterossexuais nas neuroses e nos paranóicos. Freud incluiu, assim, a homossexualidade no rol da variedade de escolhas psíquicas inconscientes humanas, externando progressivamente sua discordância dos que a entendiam como uma prédisposição biológica ou uma cultura específica.

Em uma carta datada de 9 de abril de 1935, o pai da Psicanálise respondeu a uma mãe norte-americana que havia lhe escrito preocupada com a homossexualidade do filho.

A homossexualidade não é uma vantagem, evidentemente, mas não há nada nela de que se deva ter vergonha: não é um vício nem aviltamento, nem se pode qualificá-la de doença; nós a consideramos uma variação da função sexual provocada por uma suspensão do desenvolvimento sexual. Diversos indivíduos sumamente respeitáveis, nos tempos antigos e modernos, foram homossexuais, e dentre eles 
encontramos alguns dos maiores de nossos grandes homens (Platão, Leonardo da Vinci etc). É uma grande injustiça perseguir a homossexualidade como um crime, além de ser uma crueldade. Se a senhora não acreditar em mim, leia os livros de Havelock Ellis" (FREUD apud ROUDINESCO e PLON, 1998, pág. 353) ${ }^{17}$.

Porém, como afirma Jurandir Freire Costa (1998), “a psicanálise não pensa em uníssono sobre a homossexualidade”. A partir de dezembro de 1921 os membros do Comitê Secreto (que reunia os colaboradores mais próximos de Freud, como: Karl Abraham, Hanns Sachs, Otto Rank, Sandor Ferenczi, Max Eitingon, dentre outros) dividiram-se em um debate acalorado sobre o acesso dos homossexuais à profissão de psicanalista (ROUDINESCO \& PLON, 1998). Os berlinenses eram contrários à admissão de homossexuais para formação, argumentando que a análise não era capaz de curá-los de sua inversão e, por isso, eles não seriam bons psicanalistas por definição. Otto Rank, apoiado por Freud, teria se oposto, sustentando que o acesso à formação deveria ser decidido em função da competência do candidato e não de sua sexualidade.

Ernest Jones, que presidia a $\operatorname{IPA}^{18}$ na época, teria apoiado os berlinenses e declarado que aos olhos do mundo a homossexualidade era um “crime repugnante: se um dos nossos membros o cometesse, atrairia para nós um grave descrédito" (ROUDINESCO \& PLON, 1998). Segundo a mesma autora, Jones e os berlinenses venceram o debate naquela ocasião. Nenhuma

\footnotetext{
${ }^{17}$ Em 1956, Anna Freud teria pedido à jornalista Nancy Procter-Gregg que não citasse essa carta em um artigo que ela escrevia para o The Observer. Ao contrário do pai, Anna acreditava que a Psicanálise poderia transformar homossexuais em heterossexuais e deveria fazê-lo (ROUDINESCO \& PLON, 1998).

${ }^{18}$ Associação Internacional de Psicanálise.
} 
regra foi escrita para evitar acusações de descriminação, mas várias Sociedades Psicanalíticas ao redor do mundo seguiram evitando (ou tentando evitar, como veremos a seguir) candidatos homossexuais à formação em Psicanálise.

Costa (1998) faz a ressalva de que, além de Freud, outros psicanalistas renomados como Ferenczi, Brill, Marmor, Stoller e "em certa medida" Lacan também tiveram atitudes simpáticas ou comedidas quando trataram da homossexualidade em seus trabalhos ${ }^{19}$. Ferenczi, por exemplo, teria defendido com veemência os homossexuais perseguidos na Hungria em um texto apresentado na Associação de Medicina de Budapeste em 1906, enfrentando um meio francamente hostil às suas idéias e criticando colegas médicos que indicavam o casamento como um "remédio" eficaz (ROUDINESCO \& PLON, 1998).

Anos mais tarde, um grupo que ficou conhecido como "frente gay", liderado por psicanalistas californianos, produziu o que Graña (1998) chamou de "impacto traumático" durante o $40^{\circ}$. Congresso Psicanalítico Internacional organizado pela IPA. A cada sessão, após dizer seu nome e procedência, algum membro do grupo apresentava-se como gay ou homossexual antes formular uma questão ou fazer um comentário sobre o trabalho dos colegas. Graña descreve a reação dos presentes como variações entre "um silêncio tenso", "eventuais interjeições de assombro", à "sonoras gargalhadas ansiosas"

\footnotetext{
${ }^{19}$ Poderíamos acrescentar à essa lista vários outros nomes, como os de Elizabeth Roudinesco, Jurandir Freire Costa, Georg Groddeck (1997) e Roberto Graña.
} 
quando, após alguns dias de Congresso, alguém apresentava-se para fazer uma questão apresentando-se apenas como oriundo de São Francisco.

Costa (1998) considera que após a década de setenta:

O discurso erudito, jurídico ou científico perdeu o monopólio interpretativo sobre a homossexualidade. Agora, os próprios atores reivindicam o direito de falarem sobre si de maneira socialmente legítima, e esta diferença faz uma enorme diferença. Trata-se, portanto, de saber como a psicanálise vem reagindo ao novo fenômeno, pois, historicamente, a maioria dos psicanalistas alinhou-se às fileiras dos que definiam o homossexualismo como doença, perversão ou retardamento do desenvolvimento psíquico (pág. 16)".

Graña (1998) sustenta, com preocupação, que é possível encontrar um grupo significativo de psicanalistas que pensam as questões relativas à diversidade sexual de forma preconceituosa, seguindo as idéias de autores influentes, como Charles Socarides ${ }^{20}$ ou Janine Chasseguet-Smirgel ${ }^{21}(1991)$.

Previsivelmente, as conseqüências clínicas obtidas por aqueles que tentaram transformar o desejo sexual de seus pacientes foram desastrosas e alguns psicanalistas sofreram severas criticas de grupos feministas e homossexuais principalmente a partir da metade da década de setenta (ROUDINESCO \& PLON, 1998).

A respeito especificamente da homoparentalidade, Roudinesco (2003) afirmou que:

Quando os casais homossexuais franceses obtiveram em 1999, sob os sarcasmos e as injúrias da direita parlamentar, um primeiro reconhecimento legal de sua vida comum, certos psicanalistas lacanianos adotaram, assim como seus colegas da IPA, uma posição de especialistas. Sem nada conhecerem das experiências americanas

\footnotetext{
${ }^{20}$ Representante da velha geração de Nova Iorque que defendeu com ardor as abordagens "conversoras".

${ }^{21}$ Ex-Vice Presidente da Federação Européia de Psicanálise.
} 
(de homoparentalidade), lançaram-se em uma furiosa cruzada contra aqueles que acusavam ser os adeptos de uma grande "dessimbolização" da ordem social, ou ainda os responsáveis por umas nova tentativa da supressão da diferença sexual. Os cruzados eram portanto eles próprios psicanalistas, e era em nome de Freud e de sua doutrina que atribuíam aos homossexuais a intenção mortífera outrora atribuída às mulheres (pág. 193).

Entretanto, outros psicanalistas, como Elizabeth Roudinesco (2003, 2008), opuseram-se abertamente à essa “cruzada”, e isso não se deu apenas na França. A Psicanálise esteve representada diretamente nos debates políticos brasileiros sobre o Projeto de Lei 1.151/95 a respeito da união estável entre homossexuais. Mello (2005) afirma que um grupo bastante heterogêneo foi convidado a participar das audiências públicas na Comissão Especial destinada a apreciar o Projeto 1.151. Entre eles haviam: professores universitários, religiosos, membros de grupos LGBT, dentre outros. Dois psicanalistas e um psicodramatista também participaram, dessa forma quatro profissionais com formação clínica $^{22}$ estiveram diretamente envolvidos naqueles debates. Os três mostraram-se favoráveis ao Projeto de Marta Suplicy, mas um deles - o psicanalista Cláudio Pérsio Carvalho Leite defendeu a idéia de que os contratantes da união civil deveriam ser maiores de $25 \operatorname{anos}^{23}$ e mostrou-se frontalmente contrário à possibilidade de adoção por parte de homossexuais, argumentando que a necessidade de contar com um pai-homem e uma mãe-mulher capazes de contribuir para a socialização e o desenvolvimento psicobiológico dos filhos seria “inquestionável”. Para ele,

\footnotetext{
${ }^{22}$ Contando com a autora do Projeto, a então deputada Marta Suplicy, que também é psicanalista.

${ }^{23}$ Para que, na opinião desse psicanalista, as pessoas o fizessem com maior segurança e menos angústia em relação à sua orientação sexual.
} 
pais homossexuais influenciariam inevitavelmente seus filhos de forma negativa na definição de uma orientação sexual.

Os argumentos defendidos por Cláudio Pérsio Carvalho Leite talvez sejam indicativos das divergências entre os profissionais da área a respeito das temáticas que envolvam a homossexualidade (e, acrescento, a homoparentalidade), como anteriormente descrito por Costa (1998).

\subsection{0 - As psicoterapias e o debate sobre a sexualidade}

Os clínicos e teóricos das terapias familiares, surgidas em meados do século passado, também sofreram duras críticas por parte das feministas no correr da década de setenta. Elas denunciavam o elogio ao patriarcalismo e às famílias nucleares, em detrimento de quaisquer outros tipos de organização familiar, nos trabalhos de autores importantes do campo.

De fato, pioneiros como Salvador Minuchin se tornaram críticos ferozes das mudanças técnicas e teóricas introduzidas nas últimas décadas por autores que relativizaram o que era considerado essencial para alguns dos primeiros terapeutas de família: a crença de que uma família do tipo nuclear seria o ambiente mais propício para criar indivíduos autônomos e com estabilidade interior (FÉRES-CARNEIRO, 2003).

Outros autores apontaram o silêncio a respeito das famílias homoparentais nos trabalhos dos autores mais importantes do campo. No final dos anos noventa, Clark e Serovich (2007) fizeram uma extensa pesquisa na 
qual analisaram mais de 13.000 artigos científicos em setenta e sete das mais relevantes revistas sobre terapia familiar do mundo e sustentaram que, de 1975 a 1995, apenas $0,006 \%$ dos textos analisados haviam debatido temas relacionados de alguma forma aos gays, lésbicas e bissexuais. Os autores concluíram que os autores praticamente ignoravam as temáticas relacionadas à diversidade sexual em seus trabalhos.

As associações médicas e psiquiátricas relutaram antes de retirar a homossexualidade da lista de doenças mentais do Manual Diagnóstico e Estatísticas dos Distúrbios Mentais, o DSM. Há mais de 30 anos, em 1973, a Associação Americana de Psiquiatria capitulou - em meio a debates acalorados - na questão do estatuto de doença da homossexualidade após um referendo. Dois anos depois, a Associação Norte Americana de Psicologia aconselhou os psicólogos a renunciarem aos preconceitos homófobos e a empreender pesquisas de campo junto às famílias homoparentais (KAPLAN, SADOCK \& GREBB, 1997; ROUDINESCO, 2003).

Ainda no final da década de setenta surgiram os primeiros estudos de psicólogos a respeito das famílias homoparentais. Esses estudos centravam-se nas avaliações de crianças criadas por essas famílias (PATTERSON, 1992). Os pesquisadores dedicavam-se a estudar se os filhos de casais homossexuais apresentavam diferenças, no que diz respeito ao desenvolvimento, quando comparadas às crianças criadas em outros tipos de arranjos familiares. Tendo cedido com relutância em relação ao "diagnóstico" dos pais homossexuais, os especialistas da saúde se voltaram para os filhos destes, talvez com a 
expectativa de diagnosticar neles as conseqüências da transgressão (ROUDINESCO, 2003).

Em uma extensa e importante revisão, Anderssen, Amlie e Ytterøy (2002) relataram ter encontrado vinte e três trabalhos a respeito de filhos de famílias gays e lésbicas em livros e artigos de revistas de Psicologia ou Medicina. A maior parte dos trabalhos havia surgido a partir de pesquisas realizadas por norte americanos, sendo três escritos por ingleses e um por dinamarqueses. Considerando todo o material, os estudiosos somados haviam entrevistado 615 filhos de famílias gays e lésbicas e 387 filhos de outros casais que serviram como controle. A idade dos filhos variou entre um ano e meio e quarenta e quatro anos. As avaliações realizadas pelos pesquisadores centraram-se nos seguintes aspectos: funcionamento emocional, preferência sexual, estigmatização, comportamento de gênero (comportamentos culturalmente associados com homens ou mulheres), ajustamento comportamental, identidade de gênero e funcionamento cognitivo.

A conclusão dos autores da revisão foi a de que não existiam evidências de que os filhos de famílias gays e lésbicas diferissem significativamente de outras crianças ou adultos em nenhum dos aspectos estudados. Os pesquisadores reportaram achados "surpreendentemente" (sic.) similares entre as avaliações dos filhos de casais homossexuais e os filhos de famílias com outros arranjos. Ainda segundo os autores, os resultados apoiariam a idéia de que as mulheres lésbicas deveriam ser consideradas apropriadas ou adequadas para pleitear o direito a adoções. Consideravam, ainda, que apesar do número 
de trabalhos ainda ser insuficiente em relação aos homens, provavelmente a mesma conclusão valeria para eles (ANDERSSEN; AMLIE; YTTERØY, 2002).

\subsection{1 - Mudanças nas abordagens médica e psicológica no Brasil}

No Brasil, após muitos anos de "desprezo" e "escárnio" e da ampla utilização da imagem dos homossexuais como exemplo do que poderia acontecer de indesejável às crianças caso as famílias não aderissem aos programas de educação infantil médico-higiênicos, as associações nacionais seguiram o mesmo caminho das americanas (COSTA, 1999).

Em 1984, a Associação Brasileira de Psiquiatria se opôs formalmente ao preconceito e à discriminação de homossexuais. No ano seguinte, o Conselho Federal de Medicina deixou de considerá-la uma patologia. Tardiamente, o homossexualismo deixou, ao menos oficialmente, de ser considerado uma doença ou transtorno no país.

Ainda no correr da década de oitenta foram publicados alguns trabalhos que tornariam marcos fundamentais para os estudos da homossexualidade no Brasil (FRY, 1982; MOTT, 1989; PERLONGHER,1987). Os trabalhos de Costa (1992) e Heilborn (1992) marcaram o início da década seguinte, por serem estudos nacionais bem fundamentados nos quais a conjugalidade entre pessoas do mesmo sexo ganhava destaque. No Brasil, bem como em outros países, as críticas consistentes ao essencialismo estabeleceram novas bases 
para os debates científicos sobre os temas relacionados à sexualidade e à família.

O Conselho Federal de Psicologia brasileiro também se posicionou de forma clara apresentando, no final da década de noventa, as diretrizes para o trabalho dos psicólogos em relação às questões de "orientação sexual", a resolução CFP No. 001/99 (RESOLUÇÃO, 1999). Nela, afirmava-se, dentre outros que:

CONSIDERANDO que na prática profissional, independentemente da área em que esteja atuando, o psicólogo é freqüentemente interpelado por questões ligadas à sexualidade.

CONSIDERANDO que a forma como cada um vive sua sexualidade faz parte da identidade do sujeito, a qual deve ser compreendida na sua totalidade;

CONSIDERANDO que a homossexualidade não constitui doença, nem distúrbio e nem perversão;

CONSIDERANDO que há, na sociedade, uma inquietação em torno de práticas sexuais desviantes da norma estabelecida sócio-culturalmente;

CONSIDERANDO que a Psicologia pode e deve contribuir com seu conhecimento para o esclarecimento sobre as questões da sexualidade, permitindo a superação de preconceitos e discriminações;

\section{RESOLVE:}

Art. $1^{\circ}$ - Os psicólogos atuarão segundo os princípios éticos da profissão notadamente aqueles que disciplinam a não discriminação e a promoção e bem-estar das pessoas e da humanidade.

Art. $2^{\circ}$ - Os psicólogos deverão contribuir, com seu conhecimento, para uma reflexão sobre o preconceito e o desaparecimento de discriminações e estigmatizações contra aqueles que apresentam comportamentos ou práticas homoeróticas. 
Art. $3^{\circ}$ - os psicólogos não exercerão qualquer ação que favoreça a patologização de comportamentos ou práticas homoeróticas, nem adotarão ação coercitiva tendente a orientar homossexuais para tratamentos não solicitados.

Parágrafo único - Os psicólogos não colaborarão com eventos e serviços que proponham tratamento e cura das homossexualidades.

Art. $4^{\circ}$ - Os psicólogos não se pronunciarão, nem participarão de pronunciamentos públicos, nos meios de comunicação de massa, de modo a reforçar os preconceitos sociais existentes em relação aos homossexuais como portadores de qualquer desordem psíquica.

A Resolução do CFP gerou reações. Em agosto de 2005, o Deputado Federal Elimar Máximo Damasceno do PRONA apresentou ao plenário da Câmara o projeto de lei 5816/05 que visava garantir atendimento psicológico a todos aqueles que desejassem deixar "voluntariamente a homossexualidade". Esse projeto foi arquivado. Antes do deputado Elimar, o Deputado Estadual Edino Fonseca do PSC havia apresentado um projeto semelhante na Assembléia Legislativa do Rio de Janeiro. A estratégia do Deputado Elimar incluía a revogação da Resolução 001/99 do Conselho Federal de Psicologia (IBDFAM, 2005).

Em janeiro de 2008 o Conselho Regional de Psicologia de São Paulo formalizou o funcionamento de um Grupo de Trabalho chamado de "Psicologia e LGBTs (Travestis, Transexuais e Transgêneros)". O objetivo declarado dessa Comissão seria o de promover ações no campo das políticas públicas e Direitos Humanos voltados a essa população (COMISSÕES, 2008). 
Entretanto, não é difícil encontrar profissionais e entidades que sigam trabalhando e publicando em franco desacordo com a Resolução CFP No. 001/99. Membros de organizações como o CPPC - Corpo de Psicólogos e Psiquiatras Cristãos - seguem sustentando que a homossexualidade seria uma condição de sofrimento e pecado, necessitando (portanto) de acompanhamento especializado (MOSCHETA, 2004).

Em junho de 2008, o Governo Federal brasileiro promoveu um grande evento: a $1^{\mathrm{a}}$. Conferência Nacional GLBT em Brasília (CONFERÊNCIA 2008). O tema escolhido para o encontro foi Direitos Humanos e Políticas Públicas: O caminho para garantir a cidadania de Gays, Lésbicas, Bissexuais, Travestis e Transexuais. O objetivo dos organizadores da Conferência era o de promover debates sobre políticas públicas e elaborar um Plano Nacional de Promoção da Cidadania e Direitos Humanos LGBTs. Os membros do encontro também avaliariam e proporiam estratégias para fortalecer o Brasil sem Homofobia, um programa de combate à violência e à discriminação contra LGBTs e de promoção da cidadania homossexual. Essa estratégia surgiu no Ministério da Saúde, inspirada na tradição inaugurada pelo Programa Nacional de Aids, indicando que o Estado Brasileiro passou a legitimar a formulação de políticas públicas produzidas a partir da redefinição das questões relacionadas à homossexualidade no campo dos direitos humanos e não mais como alvo de uma intervenção médico-psiquiátrica ou psicológica normatizadora da vida privada e do desejo. 
O Presidente da República, no discurso da solenidade de abertura do evento, se posicionou favoravelmente à luta por direitos dos LGBT no país, mas também se queixou da ausência de deputados e senadores, atribuindo a falta ao preconceito dos mesmos (BRASÍLIA, 2008).

Nos últimos anos verifica-se o crescimento paulatino do número de trabalhos publicados em consonância com os princípios norteadores da Resolução do CFP. Nesses, os autores abordam questões como: a conjugalidade homoparental (MOSCHETTA, 2004; UZIEL, GROSSI E MELLO, 2006), a adoção e a relação entre pais e filhos (TARNOVSKY, 2002, SANTOS, 2005; PAULO, 2006; UZIEL, 2007), os direitos das famílias e casais (RAUPP, 2008), o preconceito (ESPÍNDOLA, 2005), dentre outros. Nenhum destes, cabe mencionar, utiliza a metodologia ou aborda o tema da forma como procedemos no presente estudo. 


\section{OBJETIVOS}

Em meio a um cenário no qual se mesclam manifestações populares de grande porte (como as Paradas), decisões judiciais favoráveis e desfavoráveis às demandas dos LGBTs e reações de grupos como o CPPC, famílias se constituem e as que já existiam reivindicam direitos e ganham visibilidade social, como se aprendeu no campo do enfrentamento da epidemia do HIV/Aids, as pessoas que assumem sua orientação sexual e afirmam sua cidadania têm sido "parte da solução" e não "o problema" (PAIVA, 2007).

Levando-se em conta que as famílias homoparentais constituem-se como mais um dentre outros arranjos familiares característicos de nosso tempo (Castells, 2000) e que a união civil entre pessoas do mesmo sexo é controversa em vários países, optamos por estudar os discursos acerca do tema família articulados por membros dessas famílias. Um estudo nesse sentido poderia ser de grande valor para todos aqueles que se interessam pelas questões relacionadas ao desenvolvimento e às mudanças no âmbito das organizações familiares na contemporaneidade, como: psicólogos, cientistas sociais, membros do Judiciário, pedagogos, religiosos, médicos, dentre outros.

Nosso objetivo principal no presente trabalho será o de analisar o discurso sobre a família articulado por membros de famílias homoparentais nos moldes propostos por Guirado (1995, 2000, 2007), como veremos a seguir.

A análise abordará questões como: 
a) de que forma se organizam os discursos desses entrevistados sobre a família ${ }^{24}$ ?

b) de que modo os sujeitos descrevem suas famílias atual e de origem?

c) como descrevem as relações entre sua família e a sociedade?

d) qual o lugar que os sujeitos se atribuem ao discorrerem sobre o tema família?

e) como se posicionam a respeito da possibilidade de terem filhos e da adoção?

${ }^{24}$ Citada de forma genérica e abrangente: o que é família para você? 


\section{MÉTODO}

Utilizamos dois instrumentos para colher os dados utilizados nesse trabalho: o questionário sócio econômico (disponível no anexo 8.1) e o roteiro de entrevista da pesquisa (disponível no anexo 8.2). O roteiro de entrevista teve uma função norteadora, permitindo que os entrevistados desenvolvessem seus discursos acerca do tema família da forma mais livre possível.

As entrevistas ocorreram em horários pré-acordados, em sua maioria na residência dos entrevistados. Duas delas foram realizadas utilizando o software Skype $e^{25}$, que permite o diálogo com áudio e imagem em tempo real entre dois usuários de computadores em cidades, estados ou países diferentes. O Skype funciona como um telefone comum, com a vantagem de também transmitir imagens, além dos sons. Esse recurso foi utilizado porque dois dos entrevistados residiam em cidades distantes, o que poderia inviabilizar a sua participação na pesquisa.

Antes do início das entrevistas, todos os participantes receberam consentimentos informados (disponível no anexo 8.3) e o entrevistador pediu que estes fossem lidos com atenção, antes da assinatura. O tempo das entrevistas oscilou entre vinte e oito minutos e uma hora e quinze minutos. Todas as entrevistas foram gravadas e transcritas integralmente. As análises foram realizadas a partir do material transcrito.

\footnotetext{
${ }^{25}$ As duas entrevistas realizadas com Skype foram as de Aloísio e Rogério.
} 
O roteiro utilizado abarcava temas como: definições e conceitos de família, família de origem e família atual, relatos de experiências vividas com os membros da família atual e aspectos do relacionamento entre os familiares.

A definição desse roteiro ocorreu após um período prévio de revisão bibliográfica sobre o tema e de reuniões com o grupo de orientandos da orientadora da pesquisa, Prof. Dra. Vera Paiva, e com a Profa. Dra. Marlene Guirado, especialista em análise de discurso e criadora do método adotado para analisar os dados colhidos na pesquisa.

Utilizamos quatro critérios básicos para a escolha final de nossos entrevistados: que fossem homens, que residissem no interior paulista, que se declarassem membros de um casal ou família homoparental e que concordassem em ser entrevistados por este pesquisador. Não utilizamos dados como faixa etária ou renda familiar para excluir ou incluir entrevistados.

Iniciávamos o contato com os familiares informando que a pesquisa era parte de nosso doutorado e que estávamos procurando aprofundar os conhecimentos sobre as famílias homoparentais brasileiras. Alguns entrevistados mostraram-se satisfeitos com essas informações sobre a pesquisa, outros requisitaram uma conversa prévia para conhecer o entrevistador e questionar sobre seus objetivos, formação e orientação sexual antes de confirmarem sua participação no estudo.

O grupo estudado foi composto por dez homens, oito residentes em cidades situadas na região de Ribeirão Preto e dois moradores de outras cidades do interior paulista, com idades variando entre 23 e 44 anos (média de 
35,4 anos), que viviam com companheiros ou se declaravam casados. Contamos com dois grupos distintos de entrevistados: os casais sem filhos (seis entrevistados) e os com filhos ${ }^{26}$ (quatro entrevistados). A idade dos filhos variou de cinco a dezoito anos. Consideramos que a inclusão dos dois grupos seria importante, pois poderia enriquecer as discussões e conclusões.

A renda mensal dos entrevistados variou entre 2,9 e 10,9 salários mínimos, com média de 6,26 salários mínimos. Todos se encontravam trabalhando na época em que as entrevistas aconteceram.

Todos afirmaram ser "não negros" e apenas um havia incluído seu parceiro como dependente em seu plano de saúde. Cinco dos entrevistados afirmaram que gostariam de fazê-lo, mas por motivos variados (receio de se expor no local de trabalho, descrença em relação às leis a respeito do tema, dentre outros) não haviam tentado fazê-lo.

Nove dos entrevistados se declararam religiosos. Entre eles haviam dois católicos (um deles freqüentava a igreja e o outro não), quatro espíritas (apenas um confirmou que costumava freqüentar centros espíritas), dois adeptos da Igreja Messiânica e um que afirmou sua crença em Deus e sua descrença em religiões organizadas. Havia, ainda, um não religioso no grupo.

No que diz respeito à escolaridade, dois possuíam segundo grau incompleto, cinco estavam fazendo a formação superior e um havia

\footnotetext{
${ }^{26}$ Uziel (2007) afirma que, a grosso modo, existem atualmente três modos de um homossexual ser pai ou mãe: filhos de uma relação heterossexual anterior, adoção ou pelo uso de tecnologia. Nossos entrevistados que tinham filhos se encontravam nas duas primeiras categorias. Pesquisas como a de Zambrano (2006) sugerem que a adoção, dentre todas, seria a forma preferida entre os homossexuais. Por esse motivo adicionamos uma pergunta específica sobre adoção ao nosso roteiro.
} 
abandonado a Universidade antes de concluir sua graduação. Outros dois entrevistados haviam concluído seus cursos superiores.

\section{1 - O processo de contato e seleção de entrevistados.}

Uma das principais dificuldades enfrentadas por aqueles que realizam pesquisas com grupos de excluídos ou marginalizados refere-se à dificuldade de encontrar membros destes grupos que se disponham a participar e prestar depoimentos gravados. Não é incomum que os sujeitos dessas pesquisas considerem arriscado falar a um desconhecido. Trata-se de uma dificuldade compreensível, especialmente para pessoas identificadas com grupos que foram historicamente discriminados socialmente. Também sabemos que foram descritos como portadores de desvios ou doenças durante muitos anos.

Uma análise da bibliografia a respeito das famílias homoparentais indica que parte considerável dos primeiros artigos escritos sobre essas famílias (por pesquisadores de vários países) centrava-se na pressuposição de que seus filhos poderiam apresentar algum tipo de dificuldade quando comparados aos filhos de famílias heterossexuais. A expectativa de vários pesquisadores parecia ser a de que seus trabalhos evidenciariam déficits - e não a diversidade - nessas famílias.

A desconfiança dos candidatos a entrevistados em relação à comunidade científica não é, portanto, gratuita e constitui-se como uma barreira que deve ser considerada por quem se interessa em pesquisar nesse 
campo. Essa dificuldade é agravada se o pesquisador não pode ser identificado ao grupo.

Cientes disso, buscamos estabelecer contatos com pessoas e entidades que pudessem auxiliar a encontrar e nos apresentar aos nossos futuros entrevistados. Membros de ONGs e núcleos de estudos universitários sobre a diversidade sexual foram informados sobre nosso estudo. Também entramos em contato com outros pesquisadores de São Paulo e da região de Ribeirão Preto que já haviam realizado pesquisas ou intervenções junto a casais e famílias homoparentais para pedir indicações. Inicialmente, entramos em contato com trinta e quatro pessoas que consideramos serem candidatos em potencial ou informantes que poderiam nos levar aos nossos entrevistados.

Dentre os grupos com os quais estabelecemos contatos, os membros da ONG Rosa Vermelha e do Grupo Vide-Verso da FFCLRP-USP foram os que se mostraram mais interessados e disponíveis para auxiliar. Os coordenadores de ambos os grupos contribuíram de forma decisiva para a viabilização de várias de nossas entrevistas.

O Grupo Vide-Verso foi criado em fevereiro de 2005 na USP de Ribeirão Preto por um grupo de professores, alunos e pesquisadores interessados em desenvolver pesquisas que teriam como foco principal a diversidade sexual em suas múltiplas manifestações. O grupo mantinha, na época, três projetos de intervenção: um grupo de casais homoparentais, um grupo de pais e mães de filhos LGBTs e um grupo chamado de "Diversidade 
Sexual". Os membros do Grupo foram muito solícitos indicando candidatos a entrevistados e recomendando textos e livros sobre a temática.

Alguns membros da Rosa Vermelha, uma ONG ligada à Associação Diversidade, que congrega várias outras ONGs do Estado de São Paulo e completou treze anos de existência em 2008, também nos auxiliaram com afinco na busca por entrevistados. A Rosa Vermelha desenvolve trabalhos de prevenção às DSTs, direitos humanos, exposições e atividades culturais além de ações políticas voltadas à defesa dos direitos dos homossexuais. Trata-se de uma organização que, dentre outros, também congrega membros de famílias homoparentais que residem em Ribeirão Preto e arredores.

Durante as reuniões com os membros da ONG, da comunidade homossexual e lideranças comunitárias que atuam em projetos ligados à diversidade sexual, apresentamos detalhadamente o projeto da pesquisa em andamento, expusemos nossos objetivos em linhas gerais e a metodologia que pretendíamos utilizar. Seguiram-se debates sobre as melhores formas de realizar o trabalho e os empecilhos que poderiam ser encontrados durante a tarefa. Deixamos esses encontros com idéias mais claras sobre os vários aspectos que poderiam favorecer ou dificultar a realização do trabalho, tais como: a acentuada desconfiança dos sujeitos quanto aos propósitos de um pesquisador que não fosse um membro da comunidade, a aparente "instabilidade" (termo utilizado pelos membros da ONG) dos laços familiares dos prováveis entrevistados, os resultados e dificuldades encontrados pelos pesquisadores que haviam se proposto a pesquisar temas próximos 
anteriormente, como Moschetta (2004) e Santos (2005), as formas mais adequadas de obter acesso aos casais e aos filhos destes, dentre outros.

\section{2 - A análise dos resultados}

Escolhemos a análise de discurso ${ }^{27}$ proposta por Guirado (1995, 2000, 2007) por considerarmos que ela seria mais adequada para proceder às análises das entrevistas realizadas para essa pesquisa. Pretendemos sustentar os motivos que conduziram a esta escolha a seguir.

Guirado (2007), inspirada em Foucault, compreende método como "uma estratégia de pensamento que se organiza em torno de um conceito, ou de conceitos" que se articulam. Alguns dos principais conceitos utilizados por Guirado na construção de sua estratégia de pensamento foram formulados por autores como: Albuquerque, Foucault e Maingueneau. Discorreremos sucintamente a seguir sobre os mesmos e sobre a sua pertinência aos nossos propósitos nesse trabalho.

\section{3 - As instituições}

Um dos conceitos fundamentais para a construção da estratégia de pensamento de Guirado é o de instituição, tal como formulado por Guilhon de Albuquerque. Para esse autor, "a instituição (é considerada) como um 
conjunto de práticas ou de relações sociais que se repetem e legitimam-se enquanto se repetem" (ALBUQUERQUE apud GUIRADO, 1986, p. 39). Essa conceituação extrapola a noção de instituição como sinônimo de espaço físico ou de estabelecimento. Albuquerque nos permite identificar a instituição muito além dos mesmos. Para esse autor, as instituições estão presentes o tempo todo no cotidiano por serem práticas e relações que se repetem. Essas práticas e relações ganham legitimidade e mantém as instituições através da repetição.

Para os que operam com esse conceito de instituição, as famílias, a Medicina e o Direito (por exemplo), com suas relações, práticas e discursos característicos, são instituições. Mencionamos também o discurso, pois, como afirma Lerner, "há um nível no qual a instituição é o discurso; ou seja, no discurso, instituem-se lugares e práticas” (1999, p. 22).

Torna-se relevante, portanto, esmiuçar também a concepção de discurso com o qual a autora opera, retomando conceitos de Foucault e Maingueneau. A priori, podemos asseverar que trabalharemos com uma concepção de discurso que não admite a transparência das palavras, pois "o que se diz é opaco, isto é, qualquer sentido que possa ter será visível como uma construção a partir da análise que se faz do contexto em que a interlocução se dá" (GUIRADO, 2007, p.199).

${ }^{27}$ Escrevemos análise de discurso com minúsculas para diferenciá-la da Análise do Discurso da 


\section{4 - O discurso}

A noção de formação discursiva, tal como formulada por Michel Foucault, é fundamental para a proposta de análise de discurso desenvolvida por Guirado. Foucault conceitua o que chama de formação discursiva como se segue:

(...) um conjunto de regras anônimas, históricas, sempre determinadas no tempo e no espaço, que definiram em uma época e para uma área social, econômica, geográfica ou lingüística, as condições de exercício da função enunciativa (FOUCAULT apud MAINGUENEAU, 1989, p. 14).

Para o autor, as formações discursivas são sempre produções/construções sujeitas a regramentos históricos, à condições que lhe precedem e que estão relacionadas à épocas e contextos específicos. Esses regramentos condicionariam, para Foucault, o que seria possível e o que não seria possível dizer sobre qualquer temática em momentos históricos e sociais diferentes, conferindo ao discurso as condições de sua existência. O discurso é compreendido, então, como uma construção que carregaria consigo as marcas de sua edificação, o que nos permitiria identificar a gama de regramentos que condicionaram o exercício de sua enunciação.

Para Foucault importaria, portanto, buscar as condições em que as produções discursivas se dariam, sabendo de antemão que essas estariam intimamente relacionadas ao contexto social e institucional no qual o discurso surgiu. 
Nesse sentido, o âmbito discursivo é também caracterizado por uma relação indissociável entre saber e poder. Os discursos que veiculam saberes também criam, regulam e mantém relações de poder. Isso ocorre pois o discurso verdadeiro (ou as construções discursivas consideras verdadeiras em uma época e sociedade determinadas) confere poder aos seus detentores, em detrimento dos que não lhe tem acesso. Atualmente, dispor de discursos como o jurídico ou científico, por exemplo, significa ter acesso não apenas ao que eles veiculam, mas também ao poder que emana dos mesmos. Depreende-se então que o discurso verdadeiro de uma época não é acessível a todos indistintamente, muito pelo contrário. Dessa forma, compreendemos com Foucault que o discurso não é apenas um instrumento, ele é o motivo de lutas que foram e seguem sendo travadas. Por isso a produção e utilização do discurso verdadeiro é organizada e controlada por uma série de procedimentos específicos. Em uma aula magistral no Collége de France no início da década de setenta, Foucault (1999) enumerou os procedimentos de controle (internos e externos) e os de utilização dos discursos, como veremos a seguir:

Separação e Recusa: enquanto alguns discursos são aceitos e valorizados, outros são postos de lado, recusados.

Proibição: o acesso aos discursos, principalmente os considerados verdadeiros, é restrito. Algumas "regiões discursivas" seriam mais acessíveis do que outras e determinados discursos só seriam permitidos a grupos privilegiados. 
Exclusão fundamental: estabelece oposições demarcadas entre verdadeiro e falso. Como já afirmamos, para o autor, o que é considerado verdadeiro é sempre uma construção histórica provisória, no entanto seu caráter de produção institucional e historicidade é, via de regra, escamoteado. Para Foucault, a verdade de uma época, que norteia e subsidia discursos, é "naturalizada" 28 de diversas formas.

Foucault também descreveu uma série de procedimentos internos de controle destinados a ordenar, classificar e distribuir socialmente o discurso. Sucintamente podemos afirmar que esses procedimentos são:

Autoria: o que se escreve está prescrito em função das condições que o momento histórico e o contexto permitem e oferecem à função do autor.

Comentário: aqui Foucault tratou da repetição ou reaparição do discurso. Os comentários são comuns em textos científicos e religiosos. A repetição e reaparição tem como efeito o nivelamento ou achatamento discursivo. Neles, o autor só faz reiterar um discurso pré-existente.

Disciplina: diz respeito a todo o conjunto de regras de produção, métodos e objetos que caracterizam um discurso. O Direito, a Medicina e a Psicologia também podem ser consideradas disciplinas.

O autor menciona ainda na Ordem do discurso (1999), um terceiro grupo de procedimentos: os de utilização. Já afirmamos que, para ele, nem todas as "regiões discursivas" são acessíveis e algumas são marcadamente restritas. Alguns procedimentos garantem esse privilégio a grupos específicos.

\footnotetext{
${ }^{28}$ Como exemplos recentes podemos citar a questão da naturalização da família e da sexualidade,
} 
O autor enumerou os seguintes procedimentos de Utilização:

Sociedades de Discurso: produzem e mantém discursos de circulação restrita, definindo também quem serão os detentores e os distribuidores dos mesmos. Podemos tomar como exemplos as sociedades secretas.

Rituais: determinam a eficácia das palavras e seus efeitos em situações religiosas, por exemplo. Esse procedimento define comportamentos, gestos e todo um conjunto de signos que acompanham o discurso.

Educação: Forma de manter ou alterar a adequação dos discursos.

Doutrinas: Voltadas à difusão, vinculam pessoas (os portadores do discurso verdadeiro) a formas de enunciação mais valorizadas, em detrimento das demais.

Convém ressaltar que não realizaremos uma análise rigorosamente foucaultiana das entrevistas no presente trabalho, mas, como Guirado (2007), consideraremos alguns dos conceitos do autor como fundamentais para a estratégia de pensamento com a qual prosseguiremos trabalhando. Dentre esses, se encontram: o de formação discursiva, o de discurso verdadeiro e os que dizem respeito às relações entre saber e poder no âmbito discursivo.

\section{5 - As vozes no discurso}

No texto $O$ dizer e o dito, Drucot (apud GUIRADO, 1995) sustentou que várias vozes poderiam ser ouvidas no discurso de um mesmo falante, 
argumentando desse modo contra a noção de unidade e homogeneidade da fala. Essas múltiplas vozes seriam a do locutor e as dos enunciadores. A primeira (o locutor) seria o "eu" discursivo, aquela que se responsabiliza pelo que é dito. Os enunciadores seriam as vozes que diferem da do locutor, mas também se encontram presentes de forma clara ou escamoteada na enunciação. Os enunciadores permitem, por exemplo, que um mesmo falante emita enunciados que se contrariem, critiquem ou ironizem mutuamente. Desse modo se constitui a polifonia, que poderia ser identificada sempre que fosse possível discernir os locutores dos enunciadores (MAINGUENEAU, 1989).

Seria possível identificar as vozes dos enunciadores e o que elas dizem de formas variadas. Podemos distinguir, por exemplo, mais de uma voz no discurso sempre que se produz uma ironia, pois ela subverte o que é assumido pelo locutor e o que não é. Na ironia o enunciador pode negar o que é afirmado pelo locutor (o "eu" discursivo) em uma mesma enunciação.

Maingueneau (1989) descreve também outras marcas da heteogeneidade, tais como:

O discurso relatado (direto ou indireto): quando o locutor introduz a referência à fala de outra voz, dramatizando (no direto) ou literalmente (no indireto).

O discurso indireto livre: que preserva o caráter citatório, mas elimina (ou quase elimina) os indícios da entrada de uma outra voz. Cabe mencionar que o discurso indireto livre pode produzir um embaçamento, já que dificulta a identificação da voz que se responsabiliza pelo que está sendo dito. 
A imitação: o locutor remete aquele que o escuta ao discurso de outrem, falando a partir da lógica discursiva daquele.

As palavras entre aspas: que suspendem o sentido habitual de uma palavra ou um trecho.

O metadiscurso do locutor: indica a presença de um enunciador que, via de regra, se apresenta para defender o locutor marcando as diferenças entre níveis discursivos (Ex. eu, como membro de uma família, considero...), indicando autocorreção (melhor dizendo...) ou inadequação de termos (se é que se pode considerar).

Portanto, cabe àquele que empreende uma análise como a proposta por Guirado a tarefa de manter uma atenção redobrada às ambigüidades da palavra, às várias vozes que podem se fazer presentes em um mesmo enunciado e aos lugares que o sujeito do discurso reserva para si e para aos outros nas cenas que constrói ao falar. Nesse sentido, o discurso é compreendido como ato dispositivo, o "que implica em pensar que ele supõe posição em relação a um alvo, posição a partir de que ele (o discurso) se exerce, ou seja, supõe relações entre posições" (GUIRADO, 2000, p. 33).

\section{6 - O sujeito-dobradiça}

A concepção de sujeito utilizada por Guirado em sua estratégia de pensamento difere de forma marcante das concepções de sujeito de Foucault e Maingueneau. Para o primeiro, o sujeito é sempre rarefeito e evanescente, 
enunciador de um discurso perpassado por uma gama ampla de regramentos que organizam e, sobretudo, cerceiam as possibilidades do dizer. Já o segundo se utiliza do conceito de sujeito da enunciação, inspirado na teoria da enunciação e na pragmática.

Guirado trabalha com outro conceito, o de sujeito-dobradiça. Esse extrapolaria "o âmbito das competências individuais (o indivíduo da psicologia)" mas não se confundiria com o "sujeito-discurso" (GUIRADO, 1995). Para a autora, o sujeito-dobradiça é "dividido enquanto fala, fundado nas posições que exerce e no discurso, sempre (GUIRADO, 1995, p. 87)". Guirado propõe, desse modo, um sujeito psíquico institucionalmente fundado. Ou, como afirma Travieso, um sujeito que seja:

... fonte e efeito de discursos que o atravessam. Não indiferenciado posto manter-se (ao menos em parte) ao longo dos gêneros que o instituem, mas tampouco delimitado como "indivíduo" fechado em si e constante. Um sujeito que não é uno, que não domina seu discurso, não somente por ser sujeito do inconsciente (dimensão essencial), mas por ser enunciador/locutor de discursos que se fundamentam em estratégias fora de seu alcance... Um sujeito que alcança dimensões de identidade nos discursos, no lugar onde é situado, lugares esses que se legitimam no dizer e que podem até ser modificados, porém vivenciados como "verdadeiros", "naturais" (2001. p. 82).

Portanto, considerando o discurso em sua opacidade como um espaço que veicula saberes e distribui poderes, a polifonia discursiva e a família homoparental como uma instituição que, como outras, produz discursos sobre a família contemporânea, procuraremos descrever as cenas que os entrevistados constroem ao responder às nossas questões, identificando saberes e poderes, e utilizando a vontade de verdade, o discurso como ato e as 
marcas da heterogeneidade como os principais norteadores de nossa estratégia de pensamento.

\section{7 - O material das entrevistas}

O material com a transcrição de todas as entrevistas encontra-se na seção de anexos desta tese. Várias modificações foram feitas nas transcrições originais visando preservar o sigilo de nossos entrevistados. Nesse processo, datas, locais de acontecimentos, nomes de entrevistados, de pessoas próximas a eles e vários outros dados foram alterados. Em alguns casos suprimimos trechos de respostas que, no nosso entender, poderiam expor os entrevistados. Por outro lado mantivemos as transcrições preservando a linguagem coloquial utilizada nas entrevistas com a intenção de sermos fiéis, na medida do possível, ao que disseram nossos entrevistados, bem como ao modo como construíram suas falas.

Entretanto, mesmo que as transcrições tenham passado por esse processo de mudança, que inevitavelmente implicou em perdas, acreditamos que seria imprescindível disponibilizá-las para os leitores. Pois sempre que nos dispusemos a retornar às transcrições e o fizemos inúmeras vezes, nos deparamos com novas possibilidades de análises e "amarrações", como sugere Guirado (2007). Gostaríamos de estender o acesso à riqueza desse material aos leitores. 
Além disso, consideramos que disponibilizar as entrevistas na íntegra seria uma boa forma de conter a nossa vontade de verdade (na acepção foucaultiana), concedendo espaço para que outras análises pudessem surgir a partir daquele material.

Por isso recomendamos a leitura das mesmas. Todas as alterações e cortes não foram capazes de tornar-lhes dispensáveis. O leitor que se dispuser a lê-las certamente não se arrependerá. 


\section{A ANÁLISE DE ENTREVISTAS}

Iniciamos as entrevistas desta pesquisa pedindo a nossos interlocutores que nos contassem sobre suas histórias com seus parceiros e que o fizessem do modo que preferissem, destacando os pontos que desejassem.

\section{1 - Rapidez}

Ao rememorarem o início de suas relações, os entrevistados mencionaram, dentre outros, um aspecto que se repetiu em quase todas as entrevistas: a velocidade com que tomaram uma decisão importante.

André: Ah, eu acho que não teve uma decisão, foi, foi bem tudo no impulso, assim, tudo no sup... no, no impulso assim, no supetão.

Alexandre: É, nós tamos juntos já faz dois anos e, acho que dois, dois ou três meses, do dia que a gente se conheceu. E aí, como eu $\underline{\log o}$ comecei a ficar com ele, tal, a gente foi morar junto, tal...

Flávio: Bom, eu vou falar do início, nós nos conhecemos através de amigos e... nos gostamos muito, foi muito forte, desde o primeiro dia que nós ficamos juntos, a primeira vez, não passamos mais nenhum dia longe um do outro. Tanto que vinte dias depois a gente já tava morando junto, né? ... No vigésimo primeiro dia a gente já tava... a gente já tinha alugado um imóvel pra gente viver junto, né?

Dirceu: E era vizinho e tão pertinho. Aí ele falou assim: ah, vamos sair hoje? E desse dia pra cá a gente... nossa... sentimos uma loucura mesmo e acabamos indo morar juntos. Foi uma decisão de louco... que ninguém segurou... não sabia o que tava acontecendo, eu só me separei, né? Que eu morava com a outra menina. Mas eu só falei que não dá mais e que ia morar com ele, cheguei e contei a verdade porque foi dentro de um mês, rapidinho, porque ela descobriu mesmo também. E eu disse que eu falava: eu não sei, eu amo ele. Nossa, você ama ele? Eu falei: amo, eu falei na frente dela, bem sincero. 
André: Aí um dia a gente acabou ficando, ficando junto e... foi muito rápido, assim... a gente... é... ficou junto dia primeiro de janeiro, no aniversário dele e... em vinte dias já estávamos morando junto, já tínhamos construído tudo e no começo foi difícil, não... pela nossa relação, embora a gente não se conhecia muito, mas sim porque a gente não tinha nada, era um colchão e só, numa quitinete.

Aloísio: A gente se conheceu e... e o Jorge me encantou, tal, foi recíproco e... a gente já foi... fomos morar juntos e foi aí quando eu assumi a minha homossexualidade. Até aí então eu nunca tinha tido nenhum relacionamento homossexual é... o... aí logo eu já falei com os meus pais, que eu era... que... que eu queria, que eu tinha conhecido uma pessoa, que era outro homem, e me assumi perante minha família, né? (...) Foi amor a primeira vista... A gente se olhou, se apaixonou... a gente... se conheceu, e é... o Jorge morava sozinho e eu também já tava querendo, acho, mesmo sair do armário, tudo. $\underline{\text { Já }}$ decidimos ir morar juntos, tudo.

Nos trechos anteriores, os locutores das cenas comentaram sobre a velocidade com que decidiram ir morar com os parceiros remetendo essa decisão a um "impulso", a uma "loucura" e à força do que sentiram no início das relações. As menções à intensidade dos sentimentos - gostar, amar, apaixonar, se encantar - repetiram-se em todas as entrevistas realizadas e a esses sentimentos foram atribuídos papéis destacados no modo como os entrevistados tomaram decisões no período inicial de suas relações amorosas.

Alguns enunciados sugerem que tanto a velocidade quanto a intensidade teriam causado surpresa e algum desnorteamento aos próprios entrevistados.

Dirceu: Foi uma decisão de louco... que ninguém segurou... não sabia o que tava acontecendo, eu só me separei, né?

Flávio: É óbvio, por que a gente se ama bastante, eu... demais, é... meio inexplicável. 
Os entrevistados sustentaram que se sentiram levados, impelidos a agir por sentimentos avassaladores e inexplicáveis. Nesse contexto, a decisão de ir morar com seus parceiros amorosos assemelhou-se, em boa parte das entrevistas, menos a uma escolha (algo pelo qual o locutor das cenas se responsabilizaria) e mais a um impulso intenso e irresistível (algo que conduziria à ação). Quase como se alguns dos locutores das cenas descritas não tivessem controle sobre seus atos, tendo sido levados nesse período de suas vidas por sentimentos imperiosos e, em alguns casos, surpreendentes.

\section{2 - Companheirismo, apoio e ajuda}

Ao abordarem de modo mais detido as relações amorosas com seus parceiros, via de regra quando responderam a um questionamento sobre quais seriam as melhores características de suas relações com os mesmos, os entrevistados fizeram uso reiterado de palavras, como: companheirismo, cumplicidade, ajuda, suporte e apoio.

Mauro: Eu acho que é o companheirismo... eu acho que eu já... eu já passei por alguns problemas sérios e ele esteve do meu lado e me ajudou bastante e ele... E vice-versa também... entendeu? Problemas diferentes mas eu acho que... o... quando houve os problemas, o outro tava ali pra apoiar... então meu problema sério seria quando eu fiquei desempregado. Ele teve do meu lado pra apoiar e o meu segundo problema sério foi o de saúde que eu tive e ele também teve do meu lado.

Alexandre: Mas, assim, ele sempre me dando muito apoio, né? Sempre me apoiando muito, ele me ajuda muito, meu ritmo é muito puxado, então, se não fosse ele, eu nem saía de casa, né? Porque, tem todas as coisas, assim, que a gente precisa de casa. Suporte, tal, 
cuidar da casa, enfim (...) Eu acho que é o nosso companheirismo assim, nós somos muito companheiros. A gente praticamente não briga, nós tivemos poucas discussões assim, sabe? A gente sempre se acerta depois. A gente não é de ficar brigando, aquele casal que sai, vai no supermercado e fica brigando (...) Ele me mostrou algumas coisas. E... tudo a dois é mais fácil. Você tem um suporte, você tem um suporte financeiro, você tem um suporte emocional. Pra tudo, entendeu? Acho que essa sensação é a melhor, assim, pro relacionamento é isso daí.

Aloísio: Eu acho que nós somos companheiros, nós somos cúmplices, a gente se respeita, a gente, ao mesmo tempo que... você conviver com uma outra pessoa você tem que abrir mão de algumas coisas tuas pra poder atender as... vontades da outra pessoa e... mas isso dentro de um equilíbrio, entendeu?

Flávio: ... e eu acho que é o, é... preponderante para um relacionamento dar certo, nós somos muito cúmplices, ninguém num... num sai sem o outro, não vai pra um bar, a gente não vai pra lugar nenhum, somos muito cúmplices, a gente é muito é... é um dos pontos mais fortes que eu digo do nosso relacionamento.

Fábio: Que for importante para o nosso relacionamento? Eu acho que foi... o companheirismo muito grande de ambas as partes mas, é... ele é muito presente na minha vida, nos momentos mais difíceis, ... teve uma época que fiquei muito doente ele cuidou muito bem de mim, ele se preocupava muito. É... a gente troca muito... muitas idéias, compartilha muita coisa, ... se eu sair com alguns amigos, eu faço questão que ele esteja presente e vice-versa, então é... são coisas assim... pra mim são importantes, é... o quê mais? Acho que companheirismo me... mesmo, né? Da parte dele, pra mim foi muito importante.

Marcos: Eu acho que é o companheirismo mesmo... como o Paulo mesmo diz... é... eu acho assim... eu ajudo... eu pelo menos acho que eu ajudo e ele sempre me ajuda. Eu acho que assim ele sempre tá mais disposto em fazer algumas coisas às vezes até do que eu...

André: ...a gente é parceiro em tudo, a gente convive todos os dias juntos, a gente não consegue ficar longe um do outro em nenhum momento. Já trabalhou junto, ficamos vinte e quatro horas junto durante meses...

Seja ajudando quando surgiram problemas de saúde, apoiando nos afazeres domésticos, resolvendo conflitos do casal sem recorrer a brigas, 
provendo amparo emocional e financeiro ou estabelecendo uma parceria na divisão das tarefas e nos momentos de diversão, os entrevistados mencionaram reiteradamente a presença constante dos parceiros e a segurança de poder contar com seu auxílio e solidariedade, tanto em momentos bons quanto nos difíceis, como aspectos fundamentais de suas relações.

\section{3 - Família}

A presença, o apoio e os sentimentos amorosos também foram citados por vários entrevistados quando esses responderam a uma questão ampla sobre o que seria família, sem que especificássemos sobre qual família estávamos perguntando (“O que é família para você?”).

Flávio: Então, a família pra mim é... você tá estressado do trabalho, você tem que chegar em casa e poder conversar, esquecer aquele assunto, poder tá ali num ambiente gostoso, sabe, aquela coisa de fazer coisas junto? Que nem hoje, a gente, é... vamos ali na esquina, vamos junto, vamos no shopping, vamos fazer compra, é... o, família pra mim é... é... um ajudar o outro e ter um ambiente de felicidade, né? Amor, sempre, que nem, a família que a gente, de origem, fala (...) a melhor coisa é o amor, acho que é o sentimento, não dá pra... viver num ambiente onde não existe amor, o que existe muito por aí, então isso não é família. (...) Constituir família é morar junto com a pessoa que você realmente ama.

Dirceu: ...então eu acho que a família é aquele amor, é aquela união, você entendeu? Tem aquelas partes, é um compreender o outro, é muito diálogo... é... é isso aí, entendeu? Eu acho que o amor é a base total, o amor é a base, assim, a primeira, o primeiro alicerce da família vem o amor, depois a gente vai, o resto a gente dá jeito pra tudo, pra isso, pra aquilo, pra aquilo...

Rogério: Eu acho que família é união... família é amor... família é diálogo... família é educação... só que eu acho que tudo isso... eu acho 
que, independente de qualquer coisa, é... você cria vínculos e laços familiares pelos exemplos que você dá pro seu filho, entendeu?

Rodrigo: Família? A família não importa se é duas mulher, não importa se são dois homens, não importa se é um homem que separou da mulher pra viver com uma outra mulher, sabe? Eu acho que a família é quando vivem a dois, com respeito, caráter, dignidade... A família é quando você faz ela prosperar também... a crescer, a conseguir todas as conquistas e a família faz parte também de crise financeira que existe muito, de crise amorosa, de altos e baixos, então a família é pra um ajudar o outro, né? No que precisar, então eu acho que a família tem que vencer todas as batalhas, sempre com amor.

Portanto, seja discorrendo genericamente sobre o que seria a família, ou respondendo à questão sobre o que seria o melhor em suas relações amorosas atuais, os entrevistados referiram-se com grande freqüência aos sentimentos amorosos pelo parceiro, ao apoio (emocional, financeiro, dentre outros) e à presença constante do outro em suas respostas.

O mesmo não se verificou, entretanto, nos relatos nos quais os entrevistados discorreram sobre suas famílias de origem. Pelo contrário, estes diferiram significativamente dos relatos sobre a família (genérica) e os enunciados sobre a relação amorosa com o parceiro.

\section{4 - Família de origem}

Apesar de também mencionarem a ajuda e os sentimentos (amor, carinho, dentre outros) quando responderam à questão sobre suas famílias de origem $^{29}$, os entrevistados construíram cenas enunciativas que não se confundem com as anteriores. Estas cenas foram marcadas principalmente por 
menções a diálogos entre os entrevistados e seus familiares sobre a homossexualidade ou o envolvimento amoroso com o parceiro (e as conseqüências dessas conversas), à morte ou a problemas de saúde, à separações, à rejeição (ou à possibilidade de que ela ocorresse) e a perdas.

Fábio: É meio delicado (risos), porque, eu vivi algumas situações delicadíssimas, é... eu perdi minha mãe muito nova, minha mãe tinha, trinta e poucos anos quando ela faleceu, eu tinha doze anos de idade. Era uma barra. Antes de eu nascer... se separaram, meus pais se separaram, depois que minha mãe faleceu eu fiquei na casa de um irmão, fiquei na casa duma tia, fui morar com minha madrinha... a $\underline{\text { os }}$ quinze descobri que meu pai não era meu pai e, aí já fiquei naquela, aquela coisa revoltada, né? Aos dezesseis anos fui morar sozinho já... e sempre, assim, nunca tive apoio nem, nem de um, nem do biológico nem do... do outro. Então sempre ralei, então minha vida não foi tão fácil, não. Teve uma fase que eu entrei nas drogas, né? Pra variar... mas coisa leve, macoinha ... mas também... caí na real logo que não era aquilo que eu queria e consegui me livrar, rápido. É... meus irmãos eu tive, na época, tive pouco contato com eles... Nós viemos realmente ter é... uma vida um pouco mais assim, unida, depois dos meus trinta anos, porque hoje nós somos bem unidos, né? Apesar da distância, eles não moram aqui... Então é isso, mas, foi um pouco tumultuada e... sem grandes... é... trocas de carinho, afeto, aquela fase que eu acho muito importante para a adolescência, é... Porque na verdade... eu pulei do, tipo, dos oito anos até os doze quando minha mãe faleceu, eu já fui para fase adulta, eu acho.

Mauro: Minha família de origem é... eu e meu pai somos bastante problemáticos... a gente... pra você ter uma noção, hoje a gente não tem relação alguma... mesmo... meus pais se separaram quando eu era adolescente... mesmo quando ele era casado, eu já não me comunicava com ele. Já havia, assim, uma certa problemática entre eu e ele (...) Eu não me refiro ele como meu pai, se eu estou falando com minhas irmãs, é o seu pai. Ou, se eu tô falando com minha mãe, é seu ex-marido. É assim que é a referência... mas tirando isso... Eu me dou bem com minhas irmãs, graças a Deus, me dou muito bem com minha mãe. Minha mãe, minha irmãs e os meus cunhados, todos aceitam, tratam... é... a família dele me trata melhor... mas a minha família trata melhor ele.

André: Ah... meu pai faleceu quando eu tinha 17 anos (...) É... e... meu pai e minha mãe já era di... divor... já não tavam mais juntos, já

${ }^{29}$ Como era sua família de origem? 
não tavam mais casados. É, minha irmã casou no final da adolescência, é, teve um filho jovem e... tem dois filhinhos hoje, duas sobrinhas, uma de... completou, vai completar dois anos... Minha mãe, ela é... ela é muito nova também, então ela consegue me entender bastante, muito. Ela tem problemas com depressão, então ela é uma pessoa muito carente, então é ela é... se apegou muito a mim (...) Então, quando minha irmã casou é... eu saí de casa com 18 anos, então foi muito chocante quando eu quis sair de casa, minha mãe sofreu muito, mas eu precisava sair de casa.

Flávio:A minha família de origem? Ó... é... muito, por ser muito humilde, ser criado assim, é... não na cidade, eu mesmo nasci, é... minha... minha família não morava na cidade, morava na área rural, então a... postura que eles tinham sempre foi muito machista, então, era... um homossexual era pra eles a... aquela bichinha, era alguém que... eu cresci pensando que um gay era um cara que queria ser mulher, não era a... apenas um cara que sentia atração por um outro homem, não. Era porque queria ser mulher, né? E... foi super complicado quando minha família ficou sabendo... principalmente pelo meu pai, meu pai é muito machista, ele é machista, a família inteira, digamos assim, acredito que hoje ainda tem, saia algumas conversas entre meus primos, os parentes não tão próximos, que hoje não me interessa né?... O que me interessa são aqueles que cresceram mais ligados, minhas primas, que me ligam. Eu vou na casa da minha tia, hoje minha mãe vem em casa, depois de passados muitos problemas, a gente tem enfrentado muita coisa, né? Hoje é muito melhor (...) bom, quando ele (pai) ficou sabendo, ele me ligou, nós ficamos quase duas horas no telefone trocando ofensas né? Porque, inicialmente as coisas que ele me dizia: que ele deveria me matar, que eu deveria morrer, que eu tou envergonhando ele, coisas nesse sentido... só que nós nunca tivemos um bom relacionamento, meu pai foi meio, tem... um certo comportamento não... muito aprovado (fala rindo), digamos assim. Então eu me senti forte também pra responder, e pra poder é... bater de frente com ele, mas, graças a Deus, logo ele, depois ele se arrependeu... hoje ele... então, não comenta sobre, eu sinto que ele respeita, até o relacionamento entre a gente melhorou muito do que era há anos, hoje pelo menos ele conversa, que nem, o Cláudio ele conversa, ele olha, ele cumprimenta, ele dá a mão, ele... trata o Cláudio até melhor as vezes que... eu mesmo, a gente tinha mesmo um relacionamento difícil já antes disso, para ele é inaceitável, né?

Rodrigo: O que valeu muito a pena foi que todos os preconceitos que eu tive foi baseado, é... imaginando também que minha família jamais ia me aceitar sendo homossexual. Tanto é que minha família, quando veio a descobrir que eu era homossexual, já faziam anos que eu vivia junto com o Décio. E... e a minha mãe já tinha, nos filhos biológicos do Décio, que os filhos dele já sabiam de mim e do Décio, meus pais ainda não sabiam, não tinha... porque nós morávamos em cidades 
separadas, né? Meu pai e minha mãe achavam que o Décio era sócio meu e só, né? E... anos depois descobriram. Minha mãe, igual todas as mães, teve depressão, teve muita angústia... o meu pai olhou pra minha mãe e falou: olha, ele é filho meu do mesmo jeito e... todos os irmãos, é todos os meus filhos, os meus filhos, aquele que rejeitar, não precisa nem pisar os pés em casa. Aí a minha mãe pegou, né? Olhou pro meu pai, falou assim: ai, e agora o que eu vou fazer? E chorando, naquele desespero, tudo, e, nessa choração, meu pai falou: ó véia, que ele chama minha mãe de véia, ó véia, se você não aceitar ele, então você procura um psicólogo, procura vê direitinho, que, se você rejeitar ele, daqui a pouco, pelo menos, ele vive com alguém, dali a pouco ele vai tá ali na rua, vai tá se prostituindo, vai tá se drogando, vai tá se dopando... você tem que vê que ele é trabalhador, você tem que ver que ele próprio segurou essa história todinha com ele, todo esses longo anos... longos anos aí, e pronto. Então, graças a Deus, graças a Deus, meus familiares aceitaram tudo.

As cenas enunciativas construídas pelos entrevistados ao responderem à questão sobre suas famílias de origem diferiram significativamente das respostas dos mesmos sobre a família (citada de forma não específica) e das descrições sobre as relações com os parceiros. Se naquelas a intensidade dos sentimentos amorosos, a presença do parceiro e a rapidez da decisão de unirse aos mesmos caracterizavam as cenas, nestas as dificuldades, as perdas, o sofrimento e a violência predominaram.

Fábio mencionou a perda da mãe, a separação dos pais, a descoberta de que seu pai não era quem ele de fato pensava, a falta de apoio e a falta de carinho nas relações com a família de origem. Mauro descreveu a ausência de diálogo e de proximidade entre ele e seu pai.

André e Flávio mencionaram a morte (do pai no primeiro e a possibilidade de homicídio ou suicídio no segundo), o divórcio dos pais e a não aceitação da homossexualidade (“...para ele (pai) é inaceitável, né?”). A 
rejeição ou a expectativa de que ela ocorresse ("Então, graças a Deus, graças a Deus, meus familiares aceitaram tudo") também foi mencionada por Rodrigo.

Retomaremos uma dessas regularidades - a expectativa de não aceitação (rejeição) - de forma mais detida adiante. Por ora, basta indicar a diferença marcante entre as cenas enunciativas.

\section{5 - Segredo e medo}

Ao discorrerem sobre suas famílias de origem vários entrevistados também mencionaram episódios nos quais sentiram receio de verem expostas a sua vida amorosa e sua homossexualidade ${ }^{30}$. Discorrendo sobre os relacionamentos com membros de suas famílias de origem (pais, mães, irmãos, tios, dentre outros), alguns entrevistados afirmaram que haviam mantido sigilo a respeito desses temas por longos anos, revelando-os apenas em momentos nos quais não suportaram o "peso" de guardar segredo ou quando se sentiram obrigados a fazê-lo.

Dirceu: Minha mãe morreu já tava com uns sete anos e aí que eu fui contar pro meu pai. Na morte, depois que minha mãe morreu, que eu achei que eu tinha que contar, não agüentava mais aquele peso. Depois que minha mãe morreu, dali a uma semana, duas, eu cheguei no meu pai e falei que eu tinha que contar uma coisa pra ele muito séria.

Alexandre: Então, é... eu tive uma infância bacana, né? Eu não contei pra minha mãe que eu era gay. Só contei, fui contar pra ela mais velho, quando eu tive um... um relacionamento, eu precisei contar,

\footnotetext{
${ }^{30}$ Os entrevistados utilizaram com maior freqüência a palavra "homossexual" do que a palavra "gay" em suas respostas. Encontramos as discrepâncias numéricas mais significativas no uso das mesmas nas entrevistas de Mauro (que utilizou "homossexual" de modo muito mais freqüente) e na de Alexandre (na qual deu-se o inverso). O termo "homoafetivo" raramente foi mencionado e nenhum entrevistado mencionou a palavra "homoparental".
} 
porque a situação precisou que eu falasse pra ela, que ela não tava entendendo o que tava acontecendo (...) É, comecei a namorar um rapaz, e comecei a ficar fora de casa todo dia, às vezes dormia fora, chegava tarde. Minha mãe não entendia o que tava acontecendo, achava que eu tava namorando uma menina e... e o fato de eu já tá dormindo na casa dele logo no começo, sem apresentar pra ela, deixou ela... Minha mãe é muito encanada com esse negócio de: ah!, porque é biscate. Sabe? Ah! Porque é vulgar (...) E acho que o fato dela achar que eu tava namorando uma menina, que já tava transando, já tava dormindo com ela e nem tinha apresentado pra ela, no pensamento dela era um absurdo. E eu não contava pra ela o que tava acontecendo, né? Não podia contar. E ela começou a achar que era uma coisa errada, ou que sei lá, que eu tava envolvido com drogas, sei lá o que ela achava...

Dirceu caracterizou o ato de contar a seu pai a respeito de sua homossexualidade como uma necessidade ("eu tinha que contar...”), como se carregar aquela informação consigo tivesse se tornado um fardo insuportável.

Alexandre conferiu ao ato de conversar com sua mãe o caráter de uma obrigação ou de uma necessidade incontornável. Em ambos os casos o ato de contar parece ter sido adiado por um longo período, tornando-se possível (ou necessário) apenas em momentos especiais, após a morte da mãe ou diante de uma situação em que a mãe se encontrava desconfiada de que o entrevistado estaria fazendo algo de condenável.

Mesmo para aqueles que não guardaram segredo por tanto tempo, a preocupação e os cuidados com a exposição da relação, dos sentimentos que uniram o casal e da homossexualidade se fizeram presentes, ainda que de forma sutil. 
Nos trechos nos quais abordaram essas preocupações, eles utilizaram palavras que poderíamos associar à linguagem policial, como: desconfiar, suspeitar e policiar.

Rodrigo: .... partir do momento que a Clara (filha adotiva) conheceu bem o Décio, enquanto eu tava dando atenção pros meninos, quan... ela conheceu bem o Décio lá no abrigo, ela mandou uma carta pro juiz falando que gostou muito de mim e do Décio e que, se fosse pra separar (dos irmãos, que também aguardavam a adoção), ela já desconfiada que eu e o Décio era um casal de gay, tava lá no abrigo, se fosse pra separar ela aceitava separar dos irmãos, mando... mandando a carta pro juiz, só se fosse pra morar comigo e com o Décio, poderiam vir as duas maiores.

Mauro: No começo a gente tinha muita preocupação justam... principalmente assim por se tratar de uma cidade pequena e pela família dele, que até então não sabia...e... e realmente até hoje a gente nunca sentou e conversou com ninguém abertamente sobre isso... mas havia uma certa preocupação numa... no tratamento um com... um com o outro... a maneira como... como chamar... como conversar... porque de repente a gente tava... era Geraldo... era Gê... e houve várias situações. Eu me policiava tanto justamente por ser a... a parte da família dele que um dia aconteceu naturalmente e foram... foi em seguida assim... parece que naquela semana foi acontecendo... todo dia foi acontecendo uma. Teve um dia... a gente... ele tava na... fazendo alguma coisa na tia dele... e ele tava em cima da escada... eu tava no chão... aí ele virou: amor, pega isso pra mim. E tava todo mundo na casa da tia dele perto... e ele falou tão naturalmente que ele... ele percebeu bem depois que ele falou. Eu percebi na hora e fiquei um pouco sem reação. A tia dele, pra não deixar constrangida, saiu meio que da sala... e, acho que passou alguns segundos, ele... ele caiu na real que ele tinha falado.

Alexandre: E eu não contava pra ela o que tava acontecendo, né? Não podia contar. E ela (mãe) começou a achar que era uma coisa errada, ou que sei lá, que eu tava envolvido com drogas, sei lá o que ela achava... E a gente teve um fecha assim, feio mesmo, foi uma discussão muito feia, ela falou que era pra eu sair de casa se eu, se eu tivesse fazendo alguma coisa errada, que ela não ia me aceitar. Aí, senti necessi... senti que eu t... senti que tinha que contar, né? Senti que tinha chegado o momento extremo.

Rodrigo: E eu naquela duvida, já suspeitava que o Décio era homossexual e eu num queria mas... nem pensar em ser homossexual... 
Marcos: Não digo velho, mas assim.. um pessoal de uma cultura mais arraigada...um pessoal mais... mais... conservador... e deixar isso muito claro sem que se chocasse ninguém... muito embora isso já tinha acontecido com a minha irmã... porque ela também é... é (lésbica)... e pra eles foi um choque porque eu vivenciei isso.

Depreende-se desses trechos que a união do casal teria o potencial de causar choques, constrangimento ou abalos intensos, dentre outros, nas relações com a família de origem. Talvez essas sejam algumas das razões pelas quais vários de nossos entrevistados tenham mencionado a preocupação de manter em segredo a relação amorosa e seus sentimentos amorosos, tornando-os públicos paulatinamente ou (ao contrário) repentinamente, apenas em momentos de grande tensão, como em um desabafo.

Em boa parte dos trechos anteriores parece haver um enunciado de fundo, em relação ao qual os entrevistados se referiram, com maior freqüência, de modo indireto. Esse enunciado afirmaria que a relação amorosa deveria permanecer na surdina, como um segredo, um erro ou (talvez) um crime (daí viria a necessidade de policiamento à qual o entrevistado se referiu). Mas não seria possível, no entanto, manter o segredo sem levantar desconfianças e suspeitas.

Portanto, a possibilidade de tornar público o relacionamento foi marcada pelos cuidados e pela preocupação com as reações de choque que a notícia poderia causar entre os familiares e amigos. Em alguns casos, os entrevistados utilizaram a palavra medo ao discorrerem sobre os riscos envolvidos na exposição pública de si e de suas relações amorosas. 
Alexandre: Esses, esses termos que ela (mãe do entrevistado) ouvia, né? Como que era isso, o que acontecia, aí aquele medo de mãe de, de que alguém ia me destruir, porque eu era gay. Aí comecei a explicar, explicar... (...) De perseguição e tal. Tem, mas hoje é a partir da postura que a pessoa se coloca... não estou julgando, mas, assim, se você tem... seja um gay, seja um negro, ou seja, sei lá, um baixinho, um gordinho, alguém que tem alguma diferença, qualquer um desses diferentes do... padrão, se comportar de uma maneira... se permitir se colocar na... mas eu acho que já tem quem consegue superar isso e ter uma postura de... de querer ter seu espaço. De... não ter medo, acho que já consegue não sofrer esse tanto. Eu acho que já consegue impor o seu respeito. Nem que tiver que impor mesmo. Eu acho que já dá pra fazer isso... porque antes não, você não conseguia, né? Por mais que você gritasse, você ia levar pedrada mesmo e... acho que já dá.

Marcos: Entrar mais na questão do debate em sala de aula... porque na área em que eu trabalho isso está muito em voga (a união de pessoas do mesmo sexo e a adoção por parte de casais homoparentais)... então isso é assunto de quase de todo dia. Às vezes eu quero discutir e eu tenho medo de segurar a situação, porque eu não posso entrar muito no mérito porque... como é que você sabe tanto? $\mathrm{E}$ as pessoas sempre querem saber, não que eu não tenha, que eu tenha medo de virar pra pessoa e falar que eu sou homossexual. Qual o problema?

Rodrigo: Ela sempre jogava que os filhos biológicos do Décio iam ter muito preconceito... do pai ser gay. Mas foi correndo o ano, até mesmo eu às vezes ficava com medo se... com todo o preconceito que ela (ex-mulher do parceiro) jogava em cima de nós, eu tinha medo. Achava que poderia realmente a gente passar por barreiras.

Em alguns desses enunciados, o medo foi citado como um sentimento do entrevistado ou de um parente próximo, em outros foi negado e afirmado em seguida (“...não que eu não tenha, que eu tenha medo de virar pra pessoa e falar que eu sou homossexual"). Vários entrevistados construíram enunciados nos quais o medo e a descoberta da homossexualidade e da relação do casal estiveram reiteradamente associados. Seja em menções à mãe (que temeria que o entrevistado fosse destruído por ser gay), pelo medo de falar sobre a adoção ou o casamento homoparental com colegas e de ser questionado pelos 
mesmos (“... como é que você sabe tanto?”), ou ainda na expectativa de levar pedradas e das barreiras (citadas genericamente) a serem enfrentadas pelo casal ou pelo receio de que os filhos biológicos de seu parceiro se mostrassem preconceituosos ao descobrirem a homossexualidade do pai.

É importante salientar que esse medo das reações não se restringiu aos amigos e familiares, ele estendeu-se aos colegas de trabalho, aos religiosos, dentre outros, como veremos no correr deste capítulo. Fundada ou infundada, já que alguns entrevistados não tiveram seus temores confirmados, a preocupação em torno das conseqüências da exposição da orientação sexual e do relacionamento amoroso com o parceiro fez presente em boa parte dos discursos analisados.

\section{6 - Aceitação e rejeição}

Já afirmamos que os enunciados sobre aceitação/não aceitação, tanto da homossexualidade quanto da união homoparental foram freqüentes entre nossos entrevistados. Os sujeitos desses enunciados ${ }^{31}$ nem sempre foram os mesmos, dentre eles (com maior freqüência) se encontravam os membros das famílias de origem e, citada de forma genérica, a sociedade. Convém mencionar que nenhuma de nossas questões mencionava a palavra aceitar, sua aparição nos discursos analisados foi espontânea, o que torna a freqüência de seu uso ainda mais relevante.

${ }^{31}$ Aqueles dos quais não se esperava aceitação. 
Rodrigo: O bom exemplo, assim, da minha mãe, com toda essa descoberta que... que teve aí, né? Desses quase vinte anos aí que eu me assumi, né? A minha família, graças a Deus, aceitou assim... aceitou... muito bem, né? E minha mãe... minha mãe, na casa dos outros meus irmãos, ela vai rapidinho, já volta embora logo e tal, ela se sente muito bem mesmo na nossa casa, ela... fica assim, por exemplo, meio mês, uma semana, fica... e depois que vieram as crianças também, ela vem mais ainda visitar, com mais freqüência. Ela aceitou muito bem mesmo, sabe? A minha mãe, quando o Décio perdeu a mãe dele, ela fala que... ela adotou ele também como filho.

Alexandre: Oh, fulano é, fulano é. Pessoas que tinham referência assim, né? E aí ela começou a entender isso daí. E aí contei pro meu irmão, mas demorou. Eu percebi que demorou muito pra ela aceitar. Ela compreendeu, ela aceitou pra todo mundo, ela aceitou, ela me defendia mas eu percebi que, dentro dela, ela ainda tinha assim co... mesmo que passou um ano, assim, ela ainda tinha uma coisa assim, que eu ainda ia conhecer uma menina. E aquilo ia acabar.

Alexandre: E quando meu irmão nasceu... eu vou lá toda semana, né? Então a gente tá muito mais próximo. Então me aceitaram, gente que eu achei que nem, nunca imaginei que eles poderiam ter um fato desse na família e aceitaram tão, tão de boa, assim, naturalmente, meus priminhos, assim, tenho um afilhado que tem um priminho meu, que é meu afilhado... eles sabem, foi natural. As minhas tias, assim, receberam ele de braços abertos. Mas não tenho muito contato, não tenho, não vejo minha família, né? Pra não dar tempo de dá algum problema. (...) sabe essas brincadeiras assim? Dando a entender totalmente, abertamente que... que aceita, né? Então, normal. Não sei se sentiu tão bem recebido, mas eu vejo que ninguém... falou nada, né? Meu vô uma vez falou... falou pra minha mãe, mas minha mãe já... deu três medida nele. (risos)

Dirceu: eu tenho quatro irmãs, todas são bem casadas, eles nunca aceitaram minha vida, minha opção sexual, minha vida sexual. Depois, por eu ter sido casado, tido meus filhos... então meu pai, minhas irmãs nunca aceitaram, não por ser o Emílio, por ser um outro homem. Porque eu teria que ter uma mulher, não um homem, entendeu? Então minha família sempre teve preconceito sobre isso, $\underline{\text { nunca aceitou mas eu demorei pra contar pra eles, depois de sete, oito }}$ $\underline{\operatorname{anos}} .$.

Rodrigo afirmou ter sido aceito após ter se "assumido" perante sua família e prosseguiu mencionando que a aceitação familiar se estendeu aos filhos adotivos e ao parceiro. Ao discorrer a respeito, ele agradeceu a Deus por 
essa aceitação (“A minha família, graças a Deus, aceitou assim... aceitou... muito bem, né?”). A menção a uma força divina, que teria intercedido a seu favor, sugere um grande alívio, como se ele não estivesse esperando a aceitação.

Alexandre discorreu a respeito da dificuldade de sua mãe em aceitá-lo, mesmo que essa tivesse recebido bem sua homossexualidade, se dispondo inclusive a defendê-lo (o nos permite supor que houve quem o atacasse). Ainda assim, ela teria mantido uma esperança íntima de que ele viria a se apaixonar por uma mulher. Adiante, o mesmo entrevistado mencionou sua surpresa agradável com a reação da família de origem, o que também nos permite supor que essa não era sua expectativa. Mas o alívio externado não escondeu a preocupação com a fragilidade da aceitação, pois ele também mencionou, mesmo que de forma breve, que procurava evitar o contato próximo com seus familiares por receio de que, se houvesse uma aproximação maior, pudessem surgir problemas.

Dirceu mencionou a franca rejeição de sua opção sexual e de sua vida sexual por parte de sua família de origem, citando também o longo tempo que teria levado para contar aos parentes a esse respeito, o que sugere que a decisão de fazê-lo pode ter sido difícil.

Portanto, seja nos relatos de episódios nos quais foram ou não foram aceitos, podemos afirmar que as possibilidades de não aceitação/rejeição se fizeram presentes reiteradamente nos relatos dos entrevistados. Os que mencionaram episódios de aceitação se mostraram, via de regra, surpresos. E, 
como já afirmamos, a surpresa sugere que a aceitação não era esperada. De modo geral, podemos afirmar que, confirmada ou não, a preocupação com relação à aceitação ou à rejeição de sua opção sexual, de si mesmos e de seus parceiros foi um dos aspectos mais freqüentes nas entrevistas realizadas.

Alguns relatos sobre a primeira vez em que conversaram com os parentes mais próximos sobre suas preferências sexuais também foram marcados pela temática da aceitação/rejeição.

André: Podia até dá uma dica assim, é, fazer uma pesquisa também voltada a como e a reação dos pais quando descobrem que o filho é homossexual. Acho que é o pior momento da vida do... da... quando você tá se aceitando, você tá percebendo o que você realmente é, é... você abre isso pras pessoas que você mais confia, que são seus pais, acho que é o pior momento da sua vida, que você fica numa fase muito complicada e tem muito casos engraçados, casos... até tristes, mas acho muito interessante, porque é muito difícil essa época (...) Foi muito difícil, fiquei um ano assim, é, tentei me matar duas vezes, não aceitava em hipótese alguma, não queria, não... eu não acreditava que eu poderia ser gay ou que isso, é... fosse uma coisa válida, é, eu não acreditava que dois homens podiam casar ou que podiam construir uma família.

Alexandre: A minha mãe saiu contando pra família inteira, no sentido assim, de: meu filho é gay e se alguém falar alguma coisa, vai se ver comigo, não quero ninguém destratando e tal. E foi bacana que, as minhas tias me ligavam, pra me falar que minha mãe tinha comentado, que me amavam do mesmo jeito, todo mundo me falou isso, sabe? Ah, eu te amo, você continua sendo a mesma pessoa pra

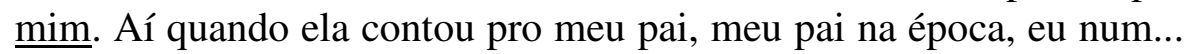
num tinha o vínculo que eu tenho com ele hoje, eu tenho um vínculo maior com ele, talvez seja até isso que nos aproximou. Ele me ligou e falou: ah, é, eu ...entendo, eu te... gosto de você.

Dirceu: Depois que minha mãe morreu, dali a uma semana, duas, $\underline{\mathrm{eu}}$ cheguei no meu pai e falei que eu tinha que contar uma coisa pra ele muito séria. Cheguei e contei que eu vivia com o Emílio, que ele não era só sócio, que eu vivia com ele, que eu amava ele e se meu pai quisesse me amar assim mesmo ou não... eu sei que depois disso podia mudar e lá no quarto ele me abraçou e chorou... e falou: nossa filho, eu te amo, eu sei que você mais agora precisa de mim. E me 
deu todo o amor do mundo, entendeu? Mas ele, no fundo, não deixou de ter um preconceito... (risos)

Nos trechos anteriores os entrevistados referiram-se à possibilidade de suicídio, de serem destratados, de não serem mais considerados as mesmas pessoas e de perderem o amor de seus familiares como riscos enfrentados no período em que revelaram aos pais sua homossexualidade e suas relações amorosas.

No primeiro trecho, após afirmar que "o pior momento de sua vida" teria sido aquele em que seus pais souberam que ele era gay, André mencionou suas duas tentativas de suicídio por não acreditar e não aceitar sua homossexualidade. Configurou-se aqui uma rejeição radical, pois, ao se definir como gay, ele deveria morrer. Cabe ressaltar que nesse trecho a rejeição não foi atribuída a um familiar ou a qualquer outra pessoa, mas ao próprio entrevistado.

No segundo trecho, Alexandre dispôs um enunciador em cena, sua mãe. Esse enunciador teria dito: "meu filho é gay e se alguém falar alguma coisa, vai se ver comigo, não quero ninguém destratando e tal". Essa frase teria sido proferida logo após ambos (mãe e filho) terem conversado sobre a orientação sexual do entrevistado. Nessa frase, o enunciador/mãe parece se antecipar para defender o locutor/filho, pressupondo que, ao saberem de sua homossexualidade (e em conseqüência disso), os outros familiares poderiam dizer coisas provavelmente indesejáveis e destratá-lo. Logo em seguida, o entrevistado mencionou frases atribuídas, dentre outros, às suas tias: "E foi 
bacana que minhas tias me ligavam, pra me falar que minha mãe tinha comentado, que me amavam do mesmo jeito, todo mundo me falou isso, sabe? Ah, eu te amo, você continua sendo a mesma pessoa pra mim”. Além do apoio das tias (que diferencia esse trecho do trecho anterior, no qual predominava a rejeição), as enunciações reafirmaram o amor daquelas e o fato das mesmas verem o entrevistado da mesma forma mesmo após saberem de sua homossexualidade, sugerindo que essa revelação poderia ter colocado em risco ou em dúvida tanto o afeto quanto o modo como o entrevistado era visto pelos familiares até então. Portanto, nesse trecho, a rejeição e a hostilidade não foram explícitas, mas ela se fizeram presentes às cenas como possibilidades as quais os enunciadores (mãe e tias) se anteciparam para proteger e reassegurar o entrevistado.

Dirceu discorreu sobre o dia em que teria contado a seu pai a respeito da relação com seu parceiro: "eu amava ele (o parceiro) e se meu pai quisesse me amar assim mesmo ou não..." Nesse trecho, a possibilidade de perder o amor do pai surge diretamente associada ao fato de assumir seu amor por outro homem, como se o fato de mencionar esse amor pudesse colocar em risco a relação entre pai e filho.

Nesses trechos, os entrevistados afirmaram ou sugeriram que, ao falar com seus familiares sobre sua homossexualidade ou a relação com seus parceiros, eles estariam se colocando em condições inevitavelmente arriscadas, sob a ameaça de serem hostilizados, rejeitados ou excluídos. Dessa forma, a revelação da escolha amorosa constituiu-se, em vários discursos, 
como uma atitude temerária, caracterizada pelos riscos variados (perda do amor, do respeito, rejeição, dentre outros) nos quais ela implicaria.

\section{7 - Vozes religiosas}

Como afirmamos, alguns dos enunciados sobre aceitação/rejeição tiveram outros sujeitos além das famílias de origem. A entrada em cena dessas outras vozes alteraram as cenas enunciativas, pois nelas as menções à rejeição e à exclusão foram mais claras. Quando as vozes religiosas entraram em cena, via de regra os enunciados referiram-se explicitamente à afirmação de modelos de família e de sexualidade que excluíam a família homoparental e os membros do casal.

Dirceu: Infelizmente, por parte da Igreja, que o certo é a família, é papai, mamãe e filhinho. Eu sou excomungado pela igreja católica. Cheguei a falar isso com um padre num debate ao vivo numa TV que eu tava... a... o cara depois veio me pedir desculpa, né? Aí eu falei assim: bom, eu não entendo porque vocês se contradizem, né? A igreja se contradiz porque ela vai contra o preceito maior do... do... do Cristianismo, que é amar ao próximo como a si mesmo.

Rodrigo: Aí eu resolvi... ir a uma igreja de crente. Cheguei lá, me abri com o pastor (sobre a homossexualidade), tudo, o pastor chegou a falar pra mim que era obra do Satanás. Não sei o quê e tal, tinha como eu mudar. Aí eu peguei e falei pro pastor: mas como que eu vou mudar, se eu não sinto nada por mulher? Aí ele falou assim: olha, se você entrar lá na Bíblia, olhar a... tem muitos que... num sentiram nada por mulher e eles dedicaram a vida pra Cristo, então ele falou que eu deveria ser missionário e tal, né? Aí eu peguei e comecei a pensar... mas como que eu vou ser missionário, como que eu vou trabalhar, como é que... eu vou ficar só pregando a palavra, do que que eu vou viver? Comecei a pensar comigo mesmo, né? Aí eu... foi... tive uma conversa com o pastor também, ele falou que a primeira coisa que eu tinha que fazer era largar também a minha 
profissão. Aí eu comecei a ficar desesperado, entre a cruz e a espada, né?

No primeiro trecho um enunciador religioso afirmou que: "o certo é a família, papai, mamãe e filhinho", um modelo que excluiria a família homoparental ou a associaria ao erro, já que a nuclear seria "o certo". O entrevistado prosseguiu afirmando que seria excomungado, portanto excluído, pela Igreja.

No trecho seguinte o entrevistador mencionou diálogos entre ele (locutor) e um pastor (enunciador religioso). Nesses, o enunciador teria associado a homossexualidade à "obra do Satanás", complementando que, apesar disso, o entrevistado poderia mudar, tornando-se missionário, dedicando a vida a Cristo, pregando a palavra e, por fim, deixando sua profissão. Criou-se dessa forma uma lógica segundo a qual não seguir os conselhos do pastor, deixando de lado a homossexualidade, seria o mesmo que dar prosseguimento à obra do demônio.

Assim, a excomunhão e a obra de Satanás foram mencionadas nos enunciados anteriores quando os enunciadores religiosos se dispuseram a afirmar um modelo ideal de família e a explicar a causa da homossexualidade. Nesses trechos, a homossexualidade ou a família homoparental foram associadas a uma escolha: renunciar às preferências sexuais, à família homoparental e ao trabalho atual ou ser excluído da igreja por contrariar preceitos bíblicos ou seguir o demônio. Desse modo, nesses trechos a escolha 
pela religiosidade implicaria na negação do desejo homossexual ou da família homoparental.

O segundo trecho selecionado também foi marcado por um aspecto que se mostraria presente em outras cenas enunciativas: a assimetria nas relações entre o locutor e o enunciador. O locutor da cena (o "eu" discursivo) angustiado e dividido procurou um enunciador/pastor que detinha um saber e era taxativo em suas recomendações. O primeiro perguntou e pediu auxílio, enquanto o segundo explicou a causa e estabeleceu o que era preciso fazer. Essa assimetria (um que detém o poder e o saber em detrimento de outro que não detém) se repetiu quando outras vozes entraram em cena, como nos próximos trechos.

Alexandre: ... Sei que tá mais fácil hoje em dia, aqui tem o juiz da vara da infância e da juventude... ele é bem aberto, ele não é um juiz preconceituoso, né? E... conheço as psicólogas que trabalham lá, a Cibele e a outra lá, que eu esqueci o nome agora, e elas são muito assim, abertas, né? Não tem uma lei específica ainda. Mas já é possível, assim... Já... já... dependendo de... do juiz que você pegar, né? Aqui mesmo já é possível, porque já teve um caso, né? Se já teve um caso, daqui a um tempo tem mais, né? A partir do momento que teve um, abre uma, abriu um caminho, mesmo que não tem na lei. $\mathrm{E}$ infelizmente tem que ser assim, não tem outro caminho. Acho que não precisava ter tudo isso se fosse uma sociedade, assim, que aceitasse, mas a gente tem que lutar, né?

Rodrigo: Muito bom, uma pessoa com um coração assim muito grande que viu o desespero, né? Numa criança que queria ir pra adoção, não importava se era homossexual ou não, e o juiz que não teve preconceito por eu viver com um outro homem e aceitou $\mathrm{o}$ pedido da menina. Porque se fosse um juiz fechado, um juiz com preconceito jamais ia liberar, né? E ele acreditou em mim e no Décio...

Rodrigo: ...por exemplo, quando a gente foi comprar nossa casa eu... foi, aí cheguei no banco, tal, tinha que incluir o nome lá no financiamento. Só que não tinha tido essa situação, eu acho que nosso caso foi o primeiro que teve. Se não foi um dos primeiros. $\underline{\mathrm{E} \text { eu }}$ 
coloquei o nome dele e quando a gente chegou lá, eu sentei com o gerente e ele questionou qual era a nossa ligação, né? E aí eu fui com uma historinha de que nós éramos sócios, que a gente queria é... construir uma coisa, assim, tal, uma casa como estabelecimento, nós éramos sócios, mas o gerente percebeu... lógico, né? Eu também não sou assim o exemplo de masculinidade, né (risos)? E ele percebeu, só que ele foi muito bacana, então acho que eu tive sorte com... nas situações que eu precisei, né? Ele... ele perguntou. Ele falou assim: olha, vou te fazer uma pergunta, vocês tem relacionamento estável, relacionamento afetivo estável?... Eu fiquei assim, né? Falei: não preciso de responder isso. Falei pra ele. Ele falou: precisa sim, quem vai aprovar sua renda sou eu. E eu não vou aprovar sua renda se você... pelo que você é, eu quero saber se você tem dinheiro pra pagar, só que eu quero a verdade... Vocês tem dinheiro, né? Ele falou. Aí ele falou pra mim: e pra mim é mais fácil conseguir liberar esse financiamento se vocês forem um casal do que se vocês forem sócios, porque como sócios vocês não têm vínculo nenhum. E eu fiquei assim, né? Totalmente sem reação. Porque já ti... já tinha tido o caso do outro banco, que eu fiquei sabendo no movimento, que, negou e entraram com um processo... e eu não queira passar por aquilo. E eu falei pra ele, assim, né? Totalmente sem com... sem controle da situação, coisa que eu não gosto (risos), já falei. Falei, e ele falou: olha, é assim... me explicou e depois ele falou: eu acho um absurdo pessoas como vocês terem que passar por isso e eu não vou barrar vocês por causa disso, eu vou cuidar disso pessoalmente. Quer dizer, não é todo homossexual que consegue isso, né? Encontrar uma pessoa assim. Se fosse alguma pessoa preconceituosa, eu não conseguiria. É igual uma ordem judicial ou processo. Se você pegar um juiz bacana, você vai conseguir o que você quer, se o cara for preconceituoso, você não vai conseguir. Entendeu?

Aqui os entrevistados contaram sobre situações nas quais dependeram da aceitação de juízes e psicólogas para prosseguir com um pedido de adoção e de um gerente de banco para obter verba para construção de uma casa. Nas situações relatadas, ao contrário do que ocorreu quando os enunciadores das cenas foram religiosos, os entrevistados obtiveram sucesso em suas demandas e a temida rejeição não ocorreu. Entretanto, em todas as três cenas os locutores dependiam de outrem (de sua "abertura" ou seu preconceito) para obter o que necessitavam. Essas também foram cenas marcadas por uma 
assimetria de poderes acentuada entre os locutores e os enunciadores, pois ao tomarem conhecimento da demanda do casal ou da "verdade" sobre o vínculo de ambos, os enunciadores deteriam o poder de emitir decisões cruciais, enquanto aos entrevistados restaria requisitar, lutar, escolher entre omitir ou revelar e contar com a sorte.

Portanto, mesmo quando as expectativas de rejeição foram revertidas e os entrevistados discorreram sobre situações nas quais se sentiram aceitos, respeitados ou apoiados, foi possível identificar o temor da rejeição (de si mesmos ou de suas requisições) e uma assimetria de poderes marcante entre os locutores das cenas e os enunciadores (juízes, psicólogas e o gerente de banco).

\section{8 - Trabalho}

A expectativa quanto à aceitação ou, nesse caso, predominantemente a rejeição também se estendeu (e de forma acentuada) ao ambiente profissional. Vários entrevistados mencionaram que seria preciso ter cuidado, não deixar claro, ficar "meio às escondidas", não comentando ou omitindo a orientação sexual e a relação com o parceiro em seus locais de trabalho.

Mauro: Então, desde que eu tô com o Geraldo, todos... ou melhor quando eu conheci o Geraldo... daquele... daquele emprego em diante... todos os meus empregos que eu tive... todos souberam que ele existia, da existência dele e quando eu fiquei desempregado desse emprego... todo mundo conhecia, gostava muito dele. Hoje, no meu atual, também tem o pessoal que adora ele.... tem uma... eu chamo ela de paraguaia, mas ela é chilena (risos). Eu falo que ela é falsificada. 
Nossa, ela tem um quê com ele. Ela adora ele, até mesmo porque ele tá ajudando ela a resolver algumas coisas... mas ela tem uma paixão por ele enorme. Então, assim, a única coisa que a gente não entrou especificamente foi em relação a isso, né? O profissional... na parte profissional como lidaria com isso, né? Mas é porque não tenho nenhum problema, não tenho esse tipo de problema... então por isso que eu acho que eu nem me importei em entrar no assunto... mas, assim, só colocando... porque, talvez, não sei se... se... isso vai te ajudar na sua pesquisa, né? No profissional tem que ficar assim... meio que... meio às escondidas... porque talvez a empresa não aceite... alguma coisa assim... eu uso brinco em todos os empregos que eu vou e nunca fui questionado... já o dele... já não pode... cabelo comprido nem brinco... Uma dureza. Mas é isso.

Marcos: Então não acho que... o grande problema hoje também da sociedade é no seu âmbito de trabalho... ter muito cuidado com relação a isso porque ainda tem muitas empresas que não admitem, né? De repente você não deixa isso claro e isso passa a ser percebido e, de repente, você tá demitido... e tem empresas que realmente não aceitam...

Flávio: se a gente vai adotar, ... a gente não queria... ver a nossa imagem aí, é, na TV, porque ia ser prejudicial pra gente no trabalho. Hoje, eu digo. Não digo daqui a três ou quatro anos, que as coisas podem estar melhor, né...?

Marcos: É... meu trabalho sempre foi uma preocupação muito grande...

André: $\mathrm{O}$ mais difícil é... acho que é... é a vida mais social, parte de... trabalho, às vezes a gente tem que, não mentir, mas omitir, pra não sofrer preconceito explícito ou... é omitir ou... é, não ser totalmente verdadeiro com as pessoas, fugir de determinados assuntos, pra não ter preconceitos, pra não ter que sofrer nenhum preconceito ou evitá-

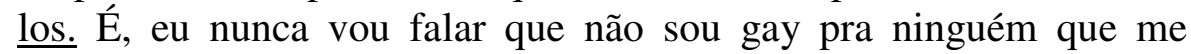
pergunta: você é homossexual? Vou falar: sou. Mas é... até chegar a esse ponto acho que... é, muito, muito diferente, assim, a pessoa quando pergunta isso é porque tem um grau de intimidade maior, às vezes eu até procuro não ter esse grau de intimidade pra não é... pra não atrapalhar no trabalho.

Flávio: Porque no trabalho às vezes a gente não pode fazer alguns comentários, sabe? (...) Eu tenho um plano médico e ele vai... na empresa, mandou chegar na empresa e dizer assim ó: ele não tem plano médico e eu quero que ele seja meu dependente, entendeu? (...) porque seria mais fácil se pudesse, se as pessoas não fossem... $\underline{\text { eu }}$ poderia chegar no meu trabalho e incluir ele no meu plano médico, ele teria a mesma cobertura que eu, a mesma segurança, então isso é muito, muito difícil, muito difícil... 
Além da preocupação com as conseqüências da exposição no ambiente profissional de suas preferências amorosas ou da constituição de suas famílias, os entrevistados mencionaram nos trechos selecionados o receio de usar brincos ou cabelos compridos, aparecer na TV e de fazer comentários sobre temas relacionados à homossexualidade. Fazê-lo seria o mesmo que se expor ao risco de um julgamento, já que a empresa poderia reagir questionando, prejudicando, não aceitando, não admitindo ou demitindo.

Os entrevistados afirmaram, dessa forma, diversos riscos ligados ao fato de se declararem (ou de aparentarem ser) homossexuais e de serem membros de famílias homoparentais. Além do trabalho, o receio afetaria também as relações com os colegas, pois aproximar-se em demasia e criar intimidade com os mesmos poderia colocar em evidência o que se pretendia omitir. Quando afirmaram que os colegas de trabalho gostavam ou perguntavam carinhosamente sobre o parceiro amoroso, alguns entrevistados se mostraram surpresos.

Nesse contexto, tornar-se membro de uma família homoparental parece ser o suficiente para colocar em perigo, dentre outros, a vida profissional e as relações interpessoais, já que seria preciso precaver-se contra os riscos da intimidade. Assim, os entrevistados afirmaram a necessidade de manter segredo a respeito da relação amorosa ou de agir de forma cuidadosa ao mencioná-la, sempre correndo riscos ao fazê-lo. Um dos entrevistados abordou essa preocupação como se segue: 
Rodrigo: Essa época pra nós foi muito difícil, a sociedade muito cheia de preconceito, falava: Décio, você é um homem, tão lindo, tão bonito, você tem três filhos. O Rodrigo não vai ter família, nunca vai ter família, então porque que, Décio? Vai, vai curtir seus filhos, volta com a sua mulher, seja homem, tal... sempre o povo colocou um ponto de interrogação na nossa vida. Sempre... e a gente querendo ou não, a gente acaba... quando você tem a sua vida mal definida, mesmo que você tá resolvido, mas... às vezes você acaba... a gente acaba sendo mal... definido, a gente acaba pondo assim uma parte nossa da mente dentro do guarda roupa, deixa lá, né?

O enunciado acima pode nos remeter à expressão "sair do armário", fartamente utilizada como sinônimo de assumir publicamente as preferências homossexuais. No entanto, a expressão ganhou um outro sentido nesse enunciado, pois para lidar com o que chamou de preconceito da sociedade, o entrevistado sustentou que, ao invés de sair do armário, seria necessário permanecer dentro do guarda roupa, escondido, longe das vistas de quem quer que seja. Cabe ressaltar que ele não estava se referindo estritamente a sua vida amorosa, pois mencionou que uma parte de sua mente precisaria permanecer longe das vistas de outrem.

\section{9 - Normal}

Em várias entrevistas também constatamos a utilização freqüente da palavra normal. Essa palavra foi utilizada em comparações entre as famílias dos entrevistados e outras, quando eles discorreram sobre seus parentes próximos e quando se referiam a si mesmos. 
Alexandre: Mas agora, assim, hoje em dia depois que eu conheci ele, no que ela (mãe do entrevistado) viu que, que tava sério, ela aprendeu. Hoje é normal. Ela me aceita, normal.

Marcos: Acho que a sociedade... ela é... ela ainda é preconceituosa pela... pelo começo dos homossexuais... eu acho que tudo teve que ser muito... era...era... tem muito tabu ainda na sociedade... e as pessoas, de repente, elas gritam, né? Pra todo mundo: olha, eu sou gay e aceite se quiser. Não é assim... eu acho que você pode mostrar pra todo mundo que o gay é uma pessoa normal, né?

André: ...tem a imagem de gay... aquele homem que se veste de mulher e fica na esquina fazendo ponto, então, então, até explicar, acho que não convém a mim ficar explicando a todo mundo (...) Também sô normal, não preciso ficar me justificando a tudo que faço.

Rogério: (discorrendo sobre sua família de origem) Uma família super simpática, eu definiria assim. Meu pai super... uma pessoa... meu pai era muito caseiro, muito amoroso. Minha mãe muito dedicada, muito trabalhadora também, eu acho que minha família é praticamente normal. Eu acho, sem problemas, sem problemas.

Aloísio: Ah, eu acho... entendi... é um relacionamento (dele com o parceiro) normal... é um relacionamento normal. Pode-se dizer que o mais difícil é acordar de manhã, um baita frio, chovendo, você ter que sair pra trabalhar. Tocar o dia-a-dia (...) A nossa relação é igual a qualquer outra relação de duas pessoas que moram juntas Se for dois pais, se foi... se são... aliás, se for um pai com o filho, se for dois irmãos, se for uma avó com uma filha, é... somos duas pessoas normais, é... a única coisa, a única diferença, é que nós somos homossexuais e isso, essa diferença, só é constatada sexualmente, e nisso, ninguém mais participa. É dentro de um quarto, em cima de uma cama, com a porta fechada. Então, nós não temos nada de diferente de outras pessoas. Nós não somos bichos, nós não somos anormais. Nós não somos extraterrestres. Nós somos normais como qualquer um... qualquer outra pessoa. As pessoas acham que a gente... num sei se todo mundo acha que a gente é dif... esses conceitos. Acordo de manhã, eu faço cocô, eu tomo café... (risos)

Seja em relação à normalidade de suas relações amorosas, de suas famílias de origem e do gay (citado pelo entrevistado de forma genérica), o que se repetiu nos trechos acima foi a defesa do caráter normal dos 
entrevistados, de suas vidas e de suas famílias. Em todos esses trechos os entrevistados afirmaram reiteradamente a sua normalidade.

No segundo trecho, por exemplo, Marcos mencionou que seria possível mostrar "para todo mundo que o gay é uma pessoa normal". Essa afirmação implica em uma suposição: a de que existam pessoas ("todo mundo") às quais seria possível (e talvez necessário) mostrar que os gays não seriam anormais.

No último trecho, Aloísio afirmou a normalidade de seu relacionamento amoroso e prosseguiu sustentando que ambos (ele e seu parceiro) não seriam diferentes de qualquer outro casal: "Então, nós não temos nada de diferente de outras pessoas". Aqui o locutor da cena construiu um enunciado aparentemente dirigido a responder a um enunciador oculto (mas, ainda assim, presente à cena), que sustentaria o inverso, ou seja, que o entrevistado e seu parceiro poderiam ser diferentes de outras pessoas.

Nesses e em outros enunciados, a afirmação da própria normalidade, bem como da normalidade de suas famílias e de suas relações amorosas sugeriram a presença velada de enunciadores aos quais seria preciso se opor ou convencer. A reiterada afirmação da normalidade só faz sentido se supusermos a existência daqueles que poderiam duvidar dela, ou que poderiam supor a sua anormalidade. Desse modo, respondendo aos enunciadores ocultos e contradizendo-os, os entrevistados afirmaram reiteradamente sua normalidade, como se fosse necessário fazê-lo. 


\subsection{0 - Promiscuidade}

Vários entrevistados mencionaram a promiscuidade, de forma direta ou sugerida, como algo que caracterizaria o (ou como um aspecto importante do) "âmbito homossexual" ou as relações homossexuais. Os entrevistados abordaram a promiscuidade majoritariamente de modo crítico, criando, dessa forma, uma distinção entre o comportamento dos promíscuos e o próprio. Mesmo quando discorreram sobre momentos de suas vidas nos quais tiveram comportamentos próximos aos descritos como promíscuos, os entrevistados se referiram ao passado, a épocas anteriores ao início da relação atual (ou a sua fase inicial), demarcando diferenças claras entre o que ocorria ontem e o que acontece atualmente em suas vidas.

Alexandre: Eu lembro que logo no começo do, da minha relação com ele, eu falei pra minha mãe: mãe, se ele for isso tudo que eu tou vendo que ele é, eu não vou perder, porque eu nunca conheci alguém assim e olha que eu conheci muita gente, que sempre fui vassourinha (risos), sabe? Sempre saía e... conheci um monte de gente, ficava mesmo, sabe? Se queria beijar o cara, beijava mesmo e nem perguntava o nome. E ia embora pra minha casa. Nunca tive pudor nenhum, assim. Pra essas coisas de: ah, vou ficar, não vou ficar, porque, sei lá, vou pegar bichinho. De, de, sabe, vai me dar sapinho. E... quer dizer, de, de todo mundo que eu conhecia e acabei fazendo um, uma amizade muito grande com essas pessoas que conhecia, a gente ficava e depois ficava amigo, assim, amizade geralmente, muito forte, muito sincera... Mas ninguém era igual ele, assim, não, não teve o encaixe.

Marcos:....eu percebi que no... no âmbito homossexual isso é mais complicado... as pessoas traem muito mais facilmente... e aí... pra mim isso era muito complicado admitir esse tipo de situação... porque eu não acreditava que as pessoas tivessem tal facilidade pra tal coisa... 
Rodrigo: A minha história no começo com o Décio é... antes de eu conhecer o Décio eu tinha tido dois outros relacionamentos, né? E... eu sempre fui, assim, em busca de um relacionamento sério, de um relacionamento... nunca entrou na minha cabeça esse negócio de ficar. Ficar pra mim nunca entrou, e achei dificuldades nos dois primeiros relacionamentos, porque imaginava que fosse ser uma coisa séria o primeiro, não foi. O segundo também não foi.... embora eu mal tava me assumindo, já me senti perdido, né? Tava complicado o relacionamento.

Alexandre: Depois daquele ano que teve aquele Jean, no Big Brother, né? Acho que ele foi uma personalidade muito importante na sociedade do Brasil pra... pro povo ter uma referência de um gay que é inteligente, centrado é... sabe? Com um pouco assim de moral, deixar um pouco aquela imagem de... de promiscuidade de lado, né? Que não sejam promíscuos, a grande maioria é... Mas acho que isso é uma consequiência da... da marginalização mesmo, né? Que ocorre. É... mas acho que tá mudando sim, eu vejo com bons olhos assim... da maneira que tá acontecendo, se tem que ser assim, acho que... de uns tempos pra cá não tem tanta violência, não tinha, não fico sabendo tanto, igual tinha antes. Igual tinha antes casos de morte assim, né? De perseguição e tal. Tem, mas hoje é a partir da postura que a pessoa se coloca... não estou julgando, mas, assim, se você tem... seja um gay, seja um negro, ou seja, sei lá, um baixinho, um gordinho, alguém que tem alguma diferença, qualquer um desses diferentes do... padrão, se comportar de uma maneira... se permitir se colocar na... mas eu acho que já tem quem consegue superar isso e ter uma postura de... de querer ter seu espaço.

No primeiro trecho Alexandre conferiu o adjetivo de "vassourinha" ao seu comportamento antes do relacionamento atual, como um sinônimo daquele que saía e beijava quem tinha vontade, com liberdade. Mas, ao conferir esse adjetivo a si mesmo, o entrevistado também sugeriu uma distinção temporal, referindo-se ao "vassourinha" como algo referente ao seu passado, à época que antecedeu o início de seu envolvimento amoroso atual ("fui vassourinha”).

Marcos estabeleceu a diferença de forma mais clara ao afirmar que nunca havia admitido a traição, situando, desse modo, os que traíam de um lado e os que não traíam de outro, e posicionando-se dentre esses últimos. No 
terceiro trecho outra dicotomia se construiu à partir da afirmação de Rodrigo de que, ao contrário de outros com os quais havia namorado, ele procurava relacionamentos sérios. Ao fazer essa afirmação, o entrevistado se diferenciou dos não sérios, afirmando a sua diferença em relação àqueles.

Alexandre mencionou elogiosamente aqueles que contribuíram para criar uma imagem do gay centrado e inteligente, em detrimento da imagem de promíscuo. Dessa forma, também criou categorias distintas - a dos gays promíscuos de um lado e a dos inteligentes, centrados, com moral e não promíscuos de outro - e posicionou-se favoravelmente apenas em relação ao últimos.

Além dessa distinção - promíscuos de um lado, entrevistados de outro alguns entrevistados também citaram os casais heterossexuais, os usuários de drogas, a prostituição, os negros, os transexuais, os transformistas e os travestis, estabelecendo comparações (positivas ou não) entre o comportamento e o respeito que a sociedade (citada de forma ampla) reservaria a estes e contrastando-os com o modo como são tratadas as famílias homoparentais.

Flávio: Mais difícil é... hoje ainda o mais difícil é... poder viver normalmente, tipo, se a gente estiver num bar, a gente não pode sentar de mão dadas, a gente não pode é... se de repente a gente ta ali, a gente não tem o... mesmo é... respeito se fosse um casal mesmo, de héteros, que estariam ali, todo mundo olharia: não, são casados. Então eu acho que isso é muito difícil.

Marcos: Não é assim... eu acho que você pode mostrar pra todo mundo que o gay é uma pessoa normal, né? Não precisa ser um travesti... nem todo mundo é um travesti, nem todo mundo é um 
transformista, nem todo mundo é um transexual, então você pode trazer isso pra sociedade com muito mais naturalidade...

André: ...não entendem, não sabem o que é isso, é, não acreditam, não acreditam que exista, tem a imagem de gay... aquele homem que

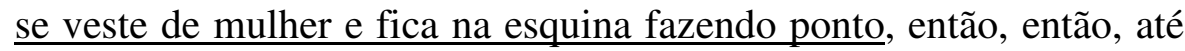
explicar, acho que não convém a mim ficar explicando a todo mundo.

Dirceu: Não, porque o pai dele não, não tinha... Como é que eu posso te dizer? Não tinha convivido com ninguém homossexual na época. Então era aquele tipo de preconceito que existe, que acha que o homossexual põe vestido, salto alto, batom na boca e fica na esquina, entendeu? Generaliza a coisa, né? Por não conhecer então no começo eu sofri um certo, assim, é... um certo preconceito da família em relação a isso.

Dirceu: Agora, se eu tô querendo pegar uma pessoa que eu não tenho laço sanguíneo nenhum... eu pretendo pegar essa pessoa, dar casa, comida, carinho, atenção, afeto, escola... é... tentar formar uma personalidade de uma pessoa decente que, se ficasse numa instituição, possivelmente deveria virar prostituta, drogado, alguma coisa assim...

Rodrigo: Então você passa a desrespeitar você mesmo, porque você vai... um exemplo... processar porque se alguém falou mal que você é homossexual? A lei não vai punir a pessoa, a lei é lenta, ou a pessoa se... se falar que uma negra é preta, é preconceito, tem pena pra isso, né? Tem anos de cadeia, não sei, de cadeia. Mas se falar: ah, o fulano é um bichinha, um gayzinho... né? Se agir com... com desrespeito, a lei é... cesta básica, num sabe nem quanto, não sei nem quanto... cesta básica, a punição é cesta básica, então isso pra mim não é punir também uma pessoa que age com preconceito...

Rodrigo: Olhou pro meu pai, falou assim: ai, e agora o que eu vou fazer? E chorando, naquele desespero, tudo, e, nessa choração, meu pai falou: ó véia, que ele chama minha mãe de véia, ó véia, se você não aceitar ele, então você procura um psicólogo, procura vê direitinho, que, se você rejeitar ele, daqui a pouco, pelo menos, ele vive com alguém, dali a pouco ele vai tá ali na rua, vai tá se prostituindo, vai tá se drogando, vai tá se dopando... você tem que vê que ele é trabalhador, você tem que ver que ele próprio segurou essa história todinha com ele, todo esses longo anos... longos anos aí, e pronto.

Ao estabelecerem comparações entre si mesmos/seus filhos/suas

famílias atuais e outros/famílias heterossexuais, os locutores e enunciadores 
das cenas construíram uma hierarquia. Nessa, o respeito, as benesses da lei e a aceitação social seriam distribuídos de forma desigual entre grupos variados. Os casais heterossexuais e os negros disporiam de um tratamento mais respeitoso por parte da sociedade do que os casais homoparentais. O mesmo não se daria com os transformistas, os transexuais, os travestis, os drogados, os michês e os moradores de rua, menos valorizados socialmente. Esses últimos seriam exemplos daqueles com os quais vários entrevistados não gostariam de ser confundidos, bem como do que poderia ocorrer de indesejável com suas crianças caso eles não as tivessem adotado.

Desse modo, diferenciando-se, por exemplo, dos promíscuos, daqueles que se prostituem e dos drogados por um lado, mas também dos negros e das famílias heterossexuais por outro, os entrevistados construíram um lugar hierárquico intermediário para si e para as famílias homoparentais, lugar que seria distinto do reservado aos "indecentes", mas que não se confundiria (por ser menos valorizado socialmente) com aquele reservado aos "negros",32 e famílias heterossexuais.

\subsection{1 - Atributos}

Em resposta à desvalorização e talvez ao risco de serem confundidos com os promíscuos, alguns entrevistados mencionaram atributos seus e de

\footnotetext{
${ }^{32}$ Como afirmou um entrevistado mais conservador.
} 
seus parceiros aparentemente destinados à obtenção da valorização (ou à normalização) de si mesmos do parceiro e do casal.

Flávio: Ó... a minha família sempre me respeitou muito e... sempre tiveram uma admiração muito grande, eu sempre batalhei, eu sempre fui, é... comecei a trabalhar, fui pagar minha faculdade, meu pai tinha os problemas dele então eu supria em casa todas a... a... as dificuldades, eu que passava por cima, eu que emendava, então minha família sempre me viu assim de uma forma de uma pessoa mesmo, é... Honesto, trabalhador, que batalha, que vai atrás daquilo que quer, e sempre muito comunicativo, sempre muito, muita afeição pela, por todo mundo, eu pude sentar e conversar, proximidade com a maioria...

Marcos: Eu sempre ia pra cidade então eu sempre falava dele na minha família... sempre assim com muito... com requisitos muito fortes... da personalidade dele, sabe? Uma pessoa culta, uma pessoa sincera, uma pessoa que sabe se comportar nos lugares, inteligente... então, assim, são quesitos de um ser humano que eu...que eu primo por isso... sabe... então eu gosto de pessoas assim...

Fala: você deveria ter uma mulher, né filho? Não é o caminho certo, né? Mas tudo bem, tudo bem, mas só que depois de ado... de adotar essas crianças, faz um ano e pouco, mudou muito pra melhor, né? Minha família, minhas irmãs não gostavam dele, nem ia na casa do pai quando ele tava, hoje elas vão, hoje elas amam e elas dizem assim que o que nós dois fizemos, nós já ganhamos o caminho do céu, já tem o pedacinho reservado (risos). E elas se emocionaram, choraram muito quando a gente chegou e contou que nós tínhamos adotado e que elas diziam assim que jamais achavam que a gente tinha, assim, essa capacidade, entendeu? De ir tão longe, então isso também uniu mais, então hoje, nossa, elas gostam muito mais dele e... entendeu? Ele entrou melhor na família nossa depois dessa ação que nós fizemos, ninguém imaginou que ia ser assim. Não foi feito por isso mas melhorou, entendeu?

Alexandre: Hoje eu sou o que sou e eu sou agradável, não porque eu sou gay ou porque eu sou hetero. Eu sou agradável porque eu tenho outras coisas na minha personalidade que me faz ter amigos, que me faz me dá bem com as pessoas, que me faz ser aceito. E essas outras características que eu tenho fazem com que as outras pessoas aceitem a minha orientação sexual melhor. A única coisa que me preocupa é que elas vejam primeiro a minha personalidade e com ela o meu mundo... gay, né? 
Nos trechos anteriores, e em outros, os entrevistados mencionaram capacidades e qualidades pessoais como a de pagar a própria faculdade, a de trabalhar, a de superar dificuldades, a de ser honesto, a de ser comunicativo e a de ter se disposto a adotar como atributos capazes de inspirar respeito, de conquistar a aceitação e de inspirar amor (e, talvez, capazes também de diminuir o impacto de outros atributos menos valorizados ou desvalorizados).

Alexandre mencionou que outros aspectos de sua personalidade (excluindo o aspecto sexual) e suas qualidades lhe permitiram conquistar amigos e aceitação, incluindo-se aí a aceitação da própria orientação sexual. De certa forma, é como se as qualidades fossem capazes de amenizar os riscos e valorizá-lo, protegendo contra a rejeição. No caso específico desse entrevistado, as qualidades e atributos teriam a função de evitar que as pessoas vissem "primeiro" a sua personalidade e seu "mundo gay" antes de terem acesso aos outros aspectos de sua personalidade. $\mathrm{O}$ risco aqui parece ser que a personalidade e o mundo gay pudessem ofuscar ou levar à desconsideração de outros aspectos do entrevistado que poderiam valorizá-lo socialmente. A personalidade e o mundo gay poderiam se sobrepor aos seus outros atributos, definindo-o, como se fossem os aspectos mais relevantes de sua personalidade aos olhos de outras pessoas. Uma experiência comum aos estigmatizados e "desacreditados", como definiu Goffman (1980).

De fato, alguns entrevistados discorreram sobre sua orientação sexual como se essa fosse mais do que um dentre outros aspectos de suas vidas, 
sugerindo que a homossexalidade seria um ponto fundamental que, de certo modo, os definiria.

André: Podia até dá uma dica assim, é, fazer uma pesquisa também voltada a como e a reação dos pais quando descobrem que o filho é homossexual (...) Acho que é o pior momento da vida do... da... quando você tá se aceitando, você tá percebendo o que você realmente é, é... você abre isso pras pessoas que você mais confia, que são seus pais, acho que é o pior momento da sua vida, que você fica numa fase muito complicada e tem muito casos engraçados, casos... até tristes, mas acho muito interessante, porque é muito difícil essa época (...) Foi assim, meu pai ficou sabendo da minha homo, homossexualidade, porque eu também não sabia na época... é, sabia que eu não era normal, que eu não era igual a todo mundo, mas não sabia exatamente o quê eu era.

Dirceu: Então...primeiramente eu fui casado... com mulher... né? Me casei... eu era uma pessoa assim... nova...com dezoito anos... e não conhecia nem homens nem mulheres... e me casei assim... porque antigamente casava virgem...né? Casei, vivi seis anos, aqueles seis anos, assim, né? Sei lá, num, num, num sabia o que eu era... sabe, assim? Sabia o que eu sentia mas eu não sabia se... se eu ia...eu não sabia nada sobre o homossexualismo e no entanto tive a minha primeira filha, tive o meu segundo filho e depois me separei da minha mulher achando que era ela que não... não... achando que em outra mulher eu ia encontrar, às vezes, o que eu procurava (...) Eu não sabia se eu queria viver com uma mulher. Não sabia quem eu era, não sabia, passei muito mal, procurei até uma psicóloga.

No primeiro trecho André se referiu a época em que decidiu conversar com os pais sobre sua homossexualidade. Ao discorrer sobre o tema mencionou que não se tratava somente de descobrir e revelar suas preferências sexuais, tratava-se de perceber aquilo que ele "realmente" era.

Dirceu se referiu ao período em que esteve casado com uma mulher, uma época em que ele não sabia sobre o "homossexualismo". Ao fazê-lo, afirmou que tratava-se de um período em que não sabia "o que eu era" e não sabia "quem eu era", de forma ampla e abrangente. 
Dessa forma, alguns entrevistados se referiram à homossexualidade não apenas como mais uma dentre outras características de suas personalidades, mas como um aspecto privilegiado, como um atributo capaz de revelar algo de fundamental a respeito de si mesmos. Uma característica capaz de ofuscar outros atributos quando exposta publicamente, arriscando aquilo (respeito, amor) que suas outras qualidades lhes haviam permitido conquistar.

\subsection{2 - Filhos}

Respondendo a uma pergunta sobre seus eventuais critérios para escolha de uma criança para adoção ou abordando o assunto por iniciativa própria, alguns entrevistados referiram-se à possibilidade de ter filhos ou ao fato de já serem pais utilizando palavras como: precisar, necessitar e completar.

Flávio: ....acho que pode-se sim criar umas regras (para adoção), um trabalho de entrevista, pra conhecer, pra saber o intuito a, das pessoas que tão adotando, a necessidade, pra gente... a gente adora criança, a gente gosta muito de criança, tanto eu quanto o, quanto ele, então, é

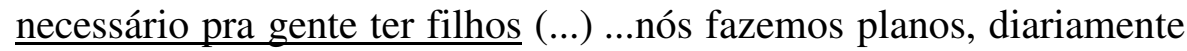
é... constituir família, é... ter filhos... é comprar um imóvel, então, a gente tá num processo de crescimento mesmo, assim profissional e pessoal, e junto, um ajuda o outro tanto na forma profissional como pessoal.

Rodrigo: Eu acho que foi tudo de bom pra minha vida, pra vida do Décio, pra completar a nossa família, pra mim acreditar mais nas leis brasileiras, porque eu acho que aqui no Brasil isso, com certeza, vai ter mais coisas boas à frente. Eu ainda não posso assim saber o quê... porque eu também não sei nem como vai finalizar o meu processo, se vai ser no nome de um ou no nome dos dois. Eu não sei.

Marcos: Mas eu tenho vontade de adotar uma criança... da gente constituir assim, digamos, uma família, né? Que eu acho que é a continuidade de um casal. Eu acho que vem daí... eu acho que a 
família... é.... o significado de família é a continuidade da vida. Eu acho que é isso... o significado de uma família, eu acho que é continuidade de vida.

Dirceu: Não, não, nunca pensei isso aqui vai ser importante. Eu só sei te dizer uma coisa, pode ter certeza, depois que nós adotamos essas crianças a nossa vida mudou, mudou pra melhor, mudou totalmente, mudou, mudou muito, mudou muito, até eu e o Emílio, você entendeu? Acho que ele precisava mesmo ter um filho porque agora eu acho, mesmo ele amando meus filhos, porque ele ama, porque meus filhos desde pequeno moraram com a gente... Ele defende meus filhos, tudo... então eu acho que, mesmo ele amando meus filhos... mas ele agora se sente... ouvir: pai, né? Me leva no dentista, ele vai em reuniões, eu deixei tudo pra ele fazer porque eu já fiz isso e eu deixei tudo para ele, ele que vai... ele que vai em tudo. Mas ele tá sendo aquele pai, assim, exemplar... entendeu? E ele vai... ele defende, vai na escola, ele é... ele é membro, ele é presidente do não sei o quê da merenda escolar... ele...ele... ele participa de tudo. Todos os dias ele pega caderno, todos os dias ele corrige, ajuda, todos os dias escova os dentes das criança, quatro, cinco vezes no dia. Ele mudou, acabou, agora não tem tempo pra nada, entendeu? Então foi só pra melhor...

Os filhos foram citados nesses e em outros trechos como mais do que uma possibilidade dentre outras. Aqui, eles foram mencionados como um dos aspectos essenciais da família (ou como o aspecto essencial da mesma) seja porque um ou os dois membros do casal sentiam não apenas uma vontade, mas uma necessidade imperiosa de ser pais, porque uma família sem filhos seria incompleta ou porque estes confeririam significado à existência da mesma.

Apenas um dentre todos os entrevistados (Fábio) afirmou que não pretendia adotar uma criança. Mas complementou fazendo a ressalva de que lhe faltaria coragem para adotar nesse momento de sua vida, já que não se sentia preparado financeiramente e emocionalmente para fazê-lo, o que não excluiria a possibilidade de uma futura adoção. 
Fábio: Eu particularmente... eu, eu... pra mim, hoje, eu, eu não, não, não teria, essa coragem... uma por que eu acho...

Entrevistador: Coragem de quê?

Fábio: De adotar (...) Eu acho que o casal tem que ter uma boa estabilidade assim, não só financeira, mas emocional. Realmente é isso que vamos querer, tal, vamos atrás e tal. Eu já te falei, eu adoro criança, gosto muito, mas pra mim, assim, não, ho... hoje não estaria preparado (...) Eu admiro que tem coragem de assumir esse, esse compromisso.

Quando questionados sobre se teriam critérios para adoção (e sobre quais seriam esses), nossos entrevistados responderam com menções ao sexo biológico (meninas foram citadas com mais freqüência), à faixa etária, às características físicas, à saúde e, destacadamente, aos sentimentos.

Rogério: Eu queria uma menina de dois a quatro anos... é... não importava cor, nem cabelo, isso pra mim não importava mas a única especif... a única coisa específica foi isso.

Marcos: ...então já tive relacionamentos com negro, já tive relacionamentos com branco, então não tenho nenhum preconceito em relação a isso... isso pra mim não é nenhum problema... mas que eu queria que fosse um recém-nascido ou uma criança de poucos meses de idade. Isso sim.

Aloísio: A gente queria uma... era só... a gente queria uma menina, porque a gente... iria se identificar mais, assim, porque pode enfeitar, aquela coisa de... de pôr roupinha, cabelo, então a gente... acredito que a gente ia curtir mais uma menina do que um menino. E... a gente sabia também que se a gente pedisse bebê ia demorar mais pra chegar, então nós escolhemos uma criança acima de dois anos de idade. Ah, o único critério assim que eu procurei... que eu falei, que eu não queria uma criança doente, com problemas físicos, é... assim... ou com AIDS, uma soropositiva, alguma coisa assim, porque... é como se fosse uma... quando a nossa filha tava pra chegar, se eu tinha opção pra essa escolha, eu não poderia escolher uma criança nessa situação porque... talvez ela seria a única filha, entendeu, então... essa criança talvez seria a única filha, então era... a filha que eu espero viver o resto da minha vida, com ela pra sempre, e não uma criança que fosse morrer logo. 
Fábio: Eu quero uma criança, eu quero cuidar de uma criança. Eu... sabe, não é... é aquela que te toca mais o coração, entendeu? (...) acho que é uma coisa mais... sentimento, aquela coisa de... né? Pelo coração.

Rodrigo: Oh, quando eu resolvi adotar... eu fui, eu fui... saí desesperado pra escolher quem eu ia adotar, né? O que mais me surpreendeu é que eu não esperava que eu ia ser adotado, você entendeu? Eu fui adotado por uma menina acima da idade que eu queria adotar, só que... eu abri o... deixei o meu coração abrir sem olhar idade, né?

André: ...vai ser a criança que tiver, assim, na nossa, na nossa mão, que a gente puder olhar pro rostinho dela, acho que vai ser aquela, num, num, independente da cor dela, se tiver algum problema ou não, vai ser a criança que a gente olhar e ver, sentir, é... que abraçar aquela criança que a gente vai ser, que nós seremos os pais daquela criança.

No primeiro trecho Rogério mencionou o sexo biológico e a idade (aspecto também citado pelo entrevistado do segundo trecho) como critérios de escolha para adoção de uma criança.

Aloísio também afirmou que desejaria adotar uma menina e fez a ressalva de que preferiria que sua primeira filha não tivesse problemas de saúde capazes de levar à morte.

Nos três últimos trechos, Fábio, Rodrigo e André destacaram os sentimentos (tocar o coração, abrir o coração) como seus principais critérios de escolha para adoção. Essas menções ao sentimento, que se repetiram nas falas de outros entrevistados, nos remeteram ao início desse capítulo, quando afirmamos que os entrevistados destacaram a intensidade dos sentimentos ao discorrerem sobre o início das relações amorosas com seus parceiros. Aqui, mesmo que alguns entrevistados tenham mencionado as características físicas, de saúde e de faixa etária, novamente os sentimentos ganharam destaque, constituindo-se como o principal critério de escolha para adoção. 
Entretanto, se os entrevistados se referiram à possibilidade de terem filhos ou ao fato de já serem pais como desejos ou necessidades, eles também abordaram essa temática como fonte de grandes preocupações.

Alexandre: Mas eu não sei como é que vai ser, nunca tive controle, eu vivi na família da minha mãe, do meu pai lá, tal, mas agora vou construir minha família. Eu chamo de desafio, assim, é... tentar não... não fazer, por exemplo, minha filha, nossa filha, né? Sofrer com isso. Tentar dar suporte pra ela conviver com isso e tentar fazer com que ela conviva com isso e supere isso na nossa cidade mesmo. Eu não sei o que vai acontecer, como vai ser a personalidade da criança, né?

Rodrigo: Com eles dois aí... no... a molecada, né? Que eu falo que criança não tem preconceito mas os pais passam, então... outras crianças falavam: ah, seu pai é gay, tal lugar eu num vou lá porque ele é gay, coisas que ferem uma criança, né?

André: Então eu acho que posso dar uma educação pro meu filho, posso educar uma criança perfeitamente... eu, com certeza ele vai ter o amor e o respeito possível, ele vai entender tudo, vou ensinar tudo o que eu puder a respeito disso, ele vai ser uma criança com certeza sem preconceito e sem... é... como fala, sem vergonha dos pais.

Marcos: ... então nós teríamos que tá presente nessa criança pra fazer a base estrutural pra ela crescer, independente se mais pra frente ela vai ter uma sexualidade diversa, isso não me importa, de jeito nenhum mas também não... não... não primo pelo sexo... se vai ser menino ou menina... não primo pela raça, de jeito nenhum... até mesmo porque eu tenho um sobrinho loiríssimo, como nós éramos quando criança, e tenho uma fi... uma sobrinha negra... que é a filha da minha irmã... então já tive relacionamentos com negro, já tive relacionamentos com branco, então não tenho nenhum preconceito em relação a isso... isso pra mim não é nenhum problema... mas que eu queria que fosse um recém-nascido ou uma criança de poucos meses de idade. Isso sim.

No primeiro trecho, Alexandre mencionou um desafio: o de tentar evitar o sofrimento da filha, dando suporte para que ela convivesse com isso (que poderia se referir à homossexualidade dos pais, ao fato de serem um casal ou à reação de outras pessoas). Além disso, mencionou sua dúvida sobre o que 
poderia acontecer à personalidade da criança. $\mathrm{O}$ entrevistado parecia antecipar a possibilidade de sofrimento e a necessidade de prover amparo à filha. Em ambos os casos essas possibilidades estariam diretamente relacionadas ao fato dela ser filha de um casal homoparental. O entrevistado também parecia preocupado com possíveis riscos à formação da personalidade da criança.

No segundo trecho, extraído da fala de Rodrigo, que já é pai adotivo, o locutor mencionou o preconceito e a hostilidade não como uma possibilidade a ser evitada, mas como uma experiência já vivida pela criança, um fato indesejável que teria ocorrido no contato com outras crianças. Aqui, os riscos de exclusão e rejeição que atingem os pais se estenderiam à filha.

André mencionou sua preocupação com a possibilidade de que o filho se tornasse preconceituoso ou de que sentisse vergonha dos pais. Seguindo a lógica do discurso do entrevistado, isso talvez pudesse ser evitado se a criança fosse criada com amor e respeito. Aqui o temor da rejeição não se restringiu à sociedade, mas estendeu-se ao que a criança poderia fazer ou sentir em relação aos pais quando crescesse.

No último trecho, Marcos mencionou a possibilidade de que seu filho desenvolvesse o que chamou de "sexualidade diversa". Antes de prosseguir, ele fez uma ressalva, como se respondesse à voz de um enunciador oculto que apontaria seu incômodo caso isso ocorresse ("independente se mais pra frente

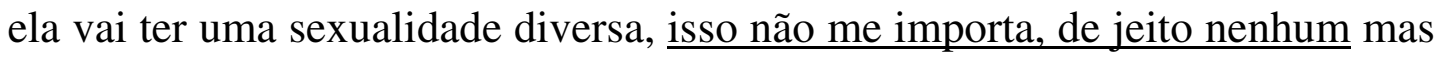
também não...”). 
Portanto, nessas e em outras passagens, os entrevistados mencionaram de forma direta ou indireta o receio de que seus filhos sofressem e fossem magoados, ou de que se tornassem preconceituosos e envergonhados em decorrência de serem membros de famílias homoparentais. Também mencionaram a possibilidade de que os filhos desenvolvessem sexualidades diversas (ou indesejáveis) e de que essas fossem consequiências do fato de serem filhos de casais homoparentais. Portanto, desejados e necessários, os filhos também foram mencionados em enunciados nos quais os entrevistados discorreram sobre suas preocupações, associando a paternidade ao temor das consequiências da sua união e à possibilidade de rejeição social de sua prole. 


\section{DE VOLTA ÀS NOSSAS QUESTÕES}

Analisadas as entrevistas, apontadas as expectativas, as regularidades, o embate entre vozes e as relações entre elas; resta retornar às nossas questões iniciais para respondê-las à partir do material analisado. Nossa intenção nesse capítulo será a de apontar como os entrevistados construíram seus discursos, que posições atribuíram a si mesmos e aos outros ao fazê-lo e identificar quais expectativas e jogos de poderes permearam as cenas enunciativas.

\section{1 - De que forma se organizam os discursos desses entrevistados sobre a família?}

Sustentei anteriormente que os discursos sobre a família, quando essa foi citada de forma inespecífica pelos entrevistados, foram marcados por menções à importância da presença dos familiares, do apoio emocional e financeiro entre os membros do casal e dos sentimentos amorosos. Nesse sentido, podemos afirmar que, ao responderem à nossa questão sobre o que seria a família, os entrevistados ressaltaram aspectos positivos que também haviam sido destacados quando discorreram sobre a relação com seus parceiros. Nos enunciados sobre a relação com os parceiros, a intensidade dos sentimentos de amor, paixão e encantamento que teriam surgido logo que os membros do casal se conheceram, o apoio mútuo, a presença e o 
companheirismo (principalmente dos membros da dupla, mas eventualmente de outros familiares) também foram destacados.

Entretanto, essas cenas discursivas ganharam outras tonalidades quando os entrevistados responderam à questão sobre suas famílias de origem. Nas respostas a respeito dessas últimas, além do apoio, da presença e dos sentimentos (citados de forma, via de regra, mais breve ou não citados), foram mencionados vários problemas de saúde, bem como a morte ou a possibilidade de que ela viesse a acontecer (por menções a pensamentos suicidas e ameaças de assassinato), separações, perdas de tipos variados e, de forma mais freqüente, rejeições.

Alguns entrevistados afirmaram que haviam mantido segredo sobre suas preferências sexuais e/ou relações amorosas, resguardando-se de revelálas às suas famílias de origem por algum ou por um longo tempo (dependendo do caso) e rompendo o sigilo a esse respeito somente em momentos nos quais se sentiram obrigados ou impelidos ao fazê-lo. As menções a preocupações e ao medo das conseqüências dessas revelações foram freqüentes quando os entrevistados contaram a respeito dessas conversas.

\section{2 - De que modo os sujeitos descrevem suas famílias atual e de origem?}

Ao contarem sobre o início dos relacionamentos que levariam à constituição de suas famílias atuais, quase todos os entrevistados mencionaram 
o tempo exíguo transcorrido entre os primeiros encontros com seus parceiros amorosos e a decisão de morarem juntos. Essa rapidez, surpreendente para alguns deles, foi atribuída a impulsos, à uma "loucura" e, principalmente à intensidade desnorteadora dos sentimentos de amor, encantamento e paixão surgidos durante ou logo após os primeiros encontros com os parceiros.

Os entrevistados também utilizaram reiteradamente palavras como "companheirismo", "apoio", "cumplicidade" e "ajuda" ao se referirem aos parceiros amorosos, conferindo uma grande importância à presença dos mesmos em suas vidas e à segurança de saber ser possível contar com seu auxílio e solidariedade nos bons e maus momentos.

Os enunciados sobre as famílias de origem apresentaram, desse modo, diferenças significativas quando comparados aos enunciados sobre as famílias atuais. Se o apoio e os sentimentos também se fizeram presentes esporadicamente em algumas das falas sobre as famílias de origem, essas mesmas falas foram marcadas de forma muito mais freqüente por menções aos diálogos entre os entrevistados e seus familiares sobre a homossexualidade (e ao medo e a expectativa de rejeição que acompanharam esses diálogos) ou sobre o envolvimento amoroso com o parceiro, bem como por relatos sobre problemas, mortes, violência, perdas e rejeição, configurando cenas enunciativas nas quais o sofrimento, as dificuldades (ou as expectativas de que estes se dessem) predominaram.

Mencionamos anteriormente que alguns entrevistados relataram ter mantido segredo durante parte de suas vidas a respeito de suas relações 
amorosas e preferências sexuais, não as mencionando principalmente (mas não apenas, como destacaremos a seguir) para os membros de suas famílias de origem. O discurso de vários entrevistados também indicou que esse segredo era acompanhado por medo e não poderia ser mantido sem acarretar em riscos. Em alguns casos, os entrevistados utilizaram palavras que nos remeteram à linguagem policial ao abordarem suas preocupações a esse respeito, como se fosse preciso redobrar as atenções para não revelar, sem as devidas precauções, segredos que poderiam acarretar em conseqüências graves.

Nossos entrevistados também discorreram sobre diversos episódios nos quais foram rejeitados, se sentiram rejeitados ou temeram a rejeição por parte de membros de suas famílias de origem. Dessa forma, afirmaram ou sugeriram que, ao conversarem com os membros de suas famílias de origem sobre suas preferências sexuais ou sobre a relação com seus parceiros amorosos, estariam se colocando em condições precárias e arriscadas, principalmente, de serem rejeitados ou excluídos.

\section{3 - Como descrevem as relações entre sua família e a sociedade?}

Afirmamos que foi recorrente a utilização da palavra medo por parte de nossos entrevistados quando esses se referiram aos riscos envolvidos ante a possibilidade de exposição pública de si, de suas preferências sexuais ou de suas relações amorosas. Dessa forma, algumas de suas falas pareceram responder a enunciadores ocultos nas cenas enunciativas, que afirmariam que 
suas relações deveriam permanecer em segredo, como se as mesmas se constituíssem em erros ou crimes.

Também sustentamos que a rejeição ou a possibilidade de rejeição permearam os discursos, se fazendo presentes nos relatos sobre fatos (passados e presentes) ou como expectativas que, mesmo quando não se cumpriram, não deixaram de causar preocupações e angústia. Além dos membros das famílias de origem, vários outros enunciadores também foram citados nessas cenas enunciativas.

Quando, por exemplo, as vozes religiosas entraram em cena, via de regra, os enunciados atribuídos a essas foram afirmativos. Neles, os enunciadores/religiosos elegeram modelos de família e de sexualidade que excluiriam a família homoparental ou os membros do casal. Desse modo, em algumas das cenas nas quais as vozes religiosas se fizeram presentes, a rejeição e a exclusão foram intensas (quando comparadas a alguns dos relatos sobre membros da família de origem), já que essas vozes afirmaram que os entrevistados deveriam escolher entre suas preferências sexuais/suas famílias homoparentais (de um lado) ou a excomunhão/o demônio (de outro). Além dessa possibilidade de exclusão radical, essas cenas enunciativas também nos permitiram identificar uma acentuada assimetria de poder nas relações entre os enunciadores/religiosos e os locutores/entrevistados, já que esses últimos perguntariam e pediriam ajuda aos primeiros, enquanto os religiosos deteriam o saber sobre as causas e sobre o que seria necessário fazer. Assim, uns 
possuiriam o conhecimento e o poder de fazer algo a respeito, enquanto outros não possuiriam.

Além dos enunciadores religiosos, outros enunciadores também foram dispostos nas cenas em lugares distintos daquele reservado aos locutores entrevistados. Os juízes, as psicólogas e o gerente de banco também dispunham do poder de emitir decisões crucias para a vida dos entrevistados. Já aos entrevistados restaria, na relação com aqueles, requisitar, escolher entre revelar ou não seus relacionamentos amorosos e contar com a sorte (ou a boa vontade dos que ouviriam suas demandas). Portanto, mesmo quando as expectativas de rejeição de si mesmos ou de seus anseios não se concretizaram (já que os enunciadores juízes, psicólogas e gerente de banco citados pelos entrevistados não se negaram a atendê-los), foi possível inferir o temor da rejeição e a assimetria marcante de poderes entre os locutores/entrevistados e os enunciadores das cenas.

A expectativa de rejeição foi ainda mais presente nos relatos a respeito dos colegas de trabalho e de suas vidas profissionais. Boa parte de nossos entrevistados afirmaram que seria prudente ou necessário ter cuidado, não deixar claro, permanecer "às escondidas" ou simplesmente omitir a homossexualidade e a relação com seus parceiros nas conversas com colegas e chefes. Esses cuidados precisariam ser redobrados já que mesmo usar brincos, ter cabelos compridos ou fazer comentários a respeito de quaisquer temas relacionados à homossexualidade poderiam ser suficientes para expor aos riscos de julgamento e demissão. Um dos entrevistados mencionou que, mais 
do que a omissão de aspectos de sua vida amorosa, ele deveria resguardar uma parte "de sua mente" das vistas de outrem para não correr riscos.

Também apontamos a grande frequiência do uso da palavra "normal" em nossas das entrevistas, sem que nenhuma das questões a mencionasse. Essa palavra foi utilizada em comparações entre as famílias dos entrevistados e outras famílias (afirmando a normalidade das primeiras em relação às segundas), quando eles discorreram sobre seus parentes próximos ou ainda quando versaram sobre si mesmos. A afirmação reiterada da normalidade nos discursos de vários entrevistados nos permitiu inferir a presença de enunciadores ocultos nas cenas aos quais seria preciso convencer ou se opor, como se estes pudessem supor o contrário, ou seja: a anormalidade dos entrevistados, de suas famílias ou de seus parentes próximos. Afinal, a afirmação insistente da normalidade só faz sentido em um contexto no qual pairam dúvidas a respeito da mesma ou no qual se supõe o inverso.

\section{4 - Qual o lugar que os sujeitos se atribuíram ao discorrerem sobre o tema família?}

Já afirmamos que foi possível identificar uma assimetria de poderes marcante nos enunciados de alguns de nossos entrevistados quando estes construíram cenas enunciativas às quais se fizeram presentes enunciadores/religiosos, juízes, psicólogas, colegas de trabalho dentre outros. Naqueles, os entrevistados construíram enunciados nos quais os 
locutores/entrevistados recorriam ou se referiram a outros que detinham saberes e poderes, temendo ou encontrando a exclusão e a rejeição ao fazê-lo.

Essa assimetria também foi marcante em vários dos enunciados sobre a família de origem, configurando cenas nas quais os locutores/entrevistados foram os portadores de segredos (sobre suas preferências sexuais e sua relação com os parceiros) que, se revelados, poderiam desencadear graves conseqüências. Uma vez revelados esses segredos, restaria aos entrevistados aguardar e desejar que seus familiares reagissem positivamente, temendo que o oposto ocorresse.

Também afirmamos que os entrevistados utilizaram a palavra "normal" com uma notável frequiência, via de regra, para afirmarem a normalidade de suas famílias atuais, de si mesmos e de suas relações amorosas, o que nos sugeriu um contexto no qual seria possível duvidar dessa normalidade. Portanto, ao discorrerem sobre a família, principalmente sobre suas famílias homoparentais em comparações com outras, os entrevistados se atribuíram lugares marcados pela suposição da anormalidade ou, ao menos, pela necessidade de defender a sua normalidade ante enunciadores que poderiam duvidar dela.

Ao discorrerem sobre si mesmos, ou ao estabelecerem comparações entre suas famílias e outras, alguns entrevistados construíram o que poderia ser compreendido como uma hierarquia própria. Nessa, aos casais heterossexuais e aos "negros" ${ }^{33}$ estaria reservado um lugar mais valorizado do que às famílias

\footnotetext{
${ }^{33}$ Citação textual de entrevistados.
} 
homoparentais. O mesmo não se daria em relação aos transformistas, transexuais, travestis, drogados, michês, moradores de rua, dentre outros. Esses últimos seriam aqueles com os quais parte de nossos entrevistados não gostariam de ser confundidos ou, ainda, representariam o que poderia ocorrer de ruim com as crianças caso elas não tivessem sido adotadas por eles. Dessa forma, os entrevistados construíram para si e suas famílias homoparentais um lugar intermediário, distinto do reservado às famílias heterossexuais e aos negros (mais valorizados e respeitados, de um lado, tendo acesso aos benefícios da lei e a aceitação social) mas também daqueles que foram chamados de promíscuos/indecentes por outro (em relação aos quais seria preciso se diferenciar).

Por outro lado, e talvez em resposta aos riscos de rejeição já mencionados e ao medo de serem confundidos com os "promíscuos", alguns entrevistados discorreram sobre vários atributos seus e de seus parceiros, como: a capacidade de pagar a faculdade, de trabalhar, de superar dificuldades, de se relacionar bem com membros da família de origem e de adotar. Para alguns entrevistados, esses atributos seriam aspectos que contribuiriam de forma decisiva para a sua valorização como pessoa, bem como para a valorização de suas famílias atuais perante os olhos das famílias de origem e, de forma mais ampla, inspirando respeito, amor e possibilitando a conquista da aceitação social.

Entretanto, os entrevistados também se referiram à sua homossexualidade e à sua família homoparental como aspectos fundamentais 
de sua identidade pessoal e de suas vida social, capazes de ofuscar atributos que os valorizariam. Nesse sentido, a exposição da orientação sexual e da sua condição familiar homoparental poderiam por a perder todos os ganhos que os outros atributos valorizados haviam permitido conquistar.

\section{5 - Como se posicionam quando discorrem sobre filhos e sobre adoção?}

Todos os entrevistados manifestaram desejo ou a necessidade de terem filhos. Apenas um se mostrou reticente a respeito desse tema e fez a ressalva de que, nesse momento de sua vida, lhe faltaria coragem para adotar uma criança. Em seguida prosseguiu afirmando que pretendia fazê-lo no futuro.

Vários de nossos entrevistados referiram-se à possibilidade de ter filhos ou ao fato de já serem pais como um dos aspectos mais importantes (ou $\underline{\mathrm{o}}$ aspecto essencial) da família e de suas vidas. Essa necessidade de ter filhos foi associada ao fato de sentirem uma vontade imperiosa de serem pais, ou porque uma família sem filhos seria incompleta ou porque os filhos confeririam significado à existência de suas famílias.

Quando questionados sobre se estabeleceriam critérios ou pré-requisitos para a escolha da(s) criança(s) a ser(em) adotada(s) e quais seriam estes, os entrevistados fizeram menções ao sexo biológico (manifestando, via de regra uma preferência por meninas), à faixa etária, às características físicas, à saúde e, de forma marcante, aos sentimentos decorrentes do encontro com a criança, 
afirmando que adotariam crianças que tocassem seus corações ou que pretendiam abrir o coração para sentir quem deveriam adotar, etc.

Entretanto, se a necessidade de ser pais e as menções aos sentimentos e desejos predominaram nos enunciados sobre filhos, alguns entrevistados também se referiram à essa temática demonstrando preocupações e dúvidas. Preocupavam-se com a possibilidade de que seus filhos viessem a sofrer ou se tornar vítimas de preconceitos e rejeição, que suas personalidades fossem afetadas de uma forma indesejável, que desenvolvessem sexualidades diversas ou, ainda, de que os mesmos filhos viessem a se envergonhar dos entrevistados/pais se tornando preconceituosos ou hostis em relação aos mesmos no futuro. Em todos esses casos, as preocupações se refeririam às consequiências destes serem filhos de famílias homoparentais, como se os entrevistados temessem as consequiências de sua união e as possíveis repercussões negativas dessa em sua prole. 


\section{DISCUSSÃO}

\section{1 - Do nascimento do homossexual à homoparentalidade}

A partir de 1869 o termo criado pelo médico húngaro Karl Kertbeny homossexualidade - foi adotado por psiquiatras e sexólogos (como: KraftEbing, Magnus Hirschfield e Havelock Ellis) para, em seguida, ser transfigurado. Se Kertbeny pretendia somente posicionar-se em relação às leis anti-sodomitas da Alemanha quando criou o termo, como afirma Weeks (2001), talvez se surpreendesse ao tomar conhecimento da fama mundial que este viria a adquirir e das amplas conseqüências de seu uso.

A psiquiatria e a sexologia fariam do homossexual um personagem muito diferente do sodomita nas décadas seguintes. O sodomita era visto como um libertino, um pecador eventual ou uma aberração temporária. Já o homossexual seria descrito posteriormente como uma classe diferenciada (e menos valorizada) de pessoas, um degenerado, o praticante de uma sexualidade anti-natural e/ou um doente mental com uma estrutura psíquica que tenderia à paranóia, à promiscuidade ${ }^{34}$ e à esquizofrenia (PARKER, 2002; FRY, 1982). Sucintamente, ele tornar-se-ia um anormal, uma outra "espécie", segundo Foucault (2001).

A temática da normalidade/anormalidade foi abordada por todos os nossos entrevistados. Como afirmamos no capítulo de análises, nenhuma de 
nossas questões mencionava de forma expressa, ou mesmo sugerida, essas palavras. A freqüência de seu uso ocorreu de forma espontânea, o que conferiu uma importância ainda maior a sua repetição. Ao discorrerem sobre si mesmos, sobre suas famílias homoparentais e sobre seus filhos, nossos entrevistados defenderam reiteradamente a sua normalidade, como se estivessem dirigindo-se àqueles que poderiam duvidar dela. Possivelmente àqueles que anteriormente haviam contribuído para criar a espécie homossexual, associando-a à anormalidade.

Muitos anos se passaram até que autores como Michel Foucault (2001) dispuseram-se a inventariar e desconstruir o que foi escrito a respeito do homossexual, ressaltando os jogos de poder envolvidos na construção desse personagem, e o caráter plural das experiências, desejos e práticas sexuais humanas.

No início da década de 70, a homossexualidade deixou de ser considerada uma categoria diagnóstica pela Associação Norte-Americana de Psiquiatria (KAPLAN, SADOCK \& GREBB, 1997), tendo sido removida do Diagnostic and Statistical Manual of Mental Disorders, sob protestos ${ }^{35}$. Nos anos seguintes as associações médicas, de psiquiatras e de psicólogos brasileiros fariam o mesmo.

Nos âmbitos social e político, grupos organizaram-se em vários países e passaram a lutar contra a opressão das minorias sexuais, iniciando um

\footnotetext{
${ }^{34}$ A promiscuidade também foi associada por nossos entrevistados aos homossexuais, como uma característica da qual eles procuraram se distanciar.

${ }^{35}$ Por parte de clínicos importantes como Socarides e Chasseguet-Smirgel, citados na introdução dessa tese.
} 
movimento que chegaria aos nossos dias com uma força notável. Atualmente os grupos LGBTs mostram-se capazes de arregimentar milhares de pessoas em suas manifestações, obtendo paulatinamente sucesso em suas demandas, questionando e alterando tanto a terminologia quanto as práticas das ciências jurídicas, médicas e psicológicas (PARKER, 2002, RAUPP, 2008; COSTA, 1999, NICHOLS \& SCHWARTZ, 1998).

Cem anos se passaram, portanto, entre o nascimento da "espécie" homossexual e o início de sua desconstrução. Nesse período foi-nos dito reiteradamente que no sexo estaria o segredo de nossa verdade (FOUCALT, 1998).

Alguns de nossos entrevistados também referiram-se às suas relações amorosas e orientação sexual como um segredo necessário e uma verdade fundamental sobre si mesmos. Ao fazê-lo, demonstraram preocupação quando mencionaram a possibilidade de (ou o momento no qual resolveram) tornar públicos seus relacionamentos amorosos e sua orientação sexual, antevendo reações indesejáveis. Ainda assim, afirmaram que teriam sentido uma vontade imperiosa ou uma necessidade de contar a outros a respeito desses temas, mas essa necessidade esteve sempre acompanhada pelo receio das conseqüências de tomar essa atitude. Um receio compreensível se considerarmos a virulência com que a homossexualidade foi descrita e tratada historicamente e a forma como a homoparentalidade foi recebida ao ganhar visibilidade social.

Roudinesco (2003) e Castells (2000) consideraram que as experiências de homoparentalidade teriam se tornado mais freqüentes em vários países no 
mesmo período em que o movimento gay se organizava "no seio de um vasto movimento de emancipação dos negros e das minorias étnicas" (ROUDINESCO, 2003), a partir da metade da década dos anos setenta do século passado.

Essas experiências e as demandas das famílias homoparentais por legitimidade jurídica e visibilidade social geraram vigorosas reações contrárias por parte de instituições religiosas e foram acompanhadas por debates políticos e jurídicos em vários países, como mencionamos anteriormente. Debates que continuam em curso, inclusive no Brasil, onde ainda não dispomos de leis que a regulamentem. A ausência de leis a esse respeito concentra o poder de decisão e a responsabilidade de acatar ou rejeitar as demandas por união estável, adoção, direito à herança, dentre outras, nas mãos dos juízes, que têm liberdade para recorrer (ou não) às jurisprudências já estabelecidas sobre o tema, ou criar novas jurisprudências. Dessa forma, essas famílias permanecem em uma condição de precariedade social e jurídica, pois elas não dispõem dos mesmos direitos garantidos por lei às outras configurações familiares.

Cabe mencionar, ainda, que a expectativa de rejeição generalizada e a assimetria de poderes (já que outros deteriam poderes de decidir sobre a aceitação ou rejeição em processos sobre união estável ou adoção, na concessão de empréstimos bancários, dentre outros) também se fizeram presentes em diversos trechos das entrevistas aqui analisadas quando as vozes religiosas, jurídicas e de psicólogos foram dispostas por nossos entrevistados 
em suas cenas enunciativas. Nesses trechos, os discursos reeditaram sentidos e expectativas que podem nos remeter ao contexto de precariedade de direitos e de cidadania no qual se encontram as famílias homoparentais brasileiras.

Quando os estudos sobre essas famílias se tornaram mais frequentes, após a capitulação oficial das sociedades de médicos e de psicólogos nas questões dos diagnósticos e tratamentos da homossexualidade, os norteamericanos preferiram referir-se a elas como gay families, para não utilizar termos vinculados à história da construção da homossexualidade como doença. Em 1997, os franceses decidiram chamá-las de famílias homoparentais. No Brasil, convém mencionar, existem autores que preferem utilizar o termo homoparentalidade, enquanto outros se referem às mesmas como famílias homossexuais ou famílias gays (UZIEL, 2007; MELLO, 2005; SANTOS, 2005; MOSCHETA, 2004).

A respeito dessa nomeação, Uziel (2007) criticou com veemência a naturalidade com que se uniram a parentalidade e a sexualidade no termo homoparentalidade. A autora argumentou, de modo convincente, que a parentalidade independeria da sexualidade dos pais e que as outras denominações utilizadas quando nos referimos às famílias - monoparental, pluriparental e recomposta, por exemplo - não confeririam destaque a orientação sexual dos membros do casal, mas a quantidade de parentes e a composição das mesmas. Cabe então perguntar: porque ressaltar a orientação sexual dos pais quando nos referimos às famílias homoparentais ou gay families? E quais as consequiências de fazê-lo? 


\section{2 - Os aspectos estratégicos}

A criação e a utilização de uma terminologia específica para se referir às famílias homoparentais ou gay families envolvem, ao menos, dois aspectos estratégicos. O primeiro, mencionado por Uziel (2007), seria o ganho de visibilidade social por parte dessas famílias, que por muito tempo foram ignoradas, como mencionado no início dessa tese.

O segundo aspecto estratégico foi descrito por Foucault, que tratou desse tema quando discorreu a respeito daqueles que chamou de movimentos de "liberação sexual". Foucault (1998), afirmou que esses deveriam ser considerados como:

...movimentos de afirmação "a partir" da sexualidade. Isto quer dizer duas coisas: são movimentos que partem da sexualidade, do dispositivo de sexualidade no interior do qual nós estamos presos, que fazem com que ele funcione até seu limite; mas, ao mesmo tempo, eles se deslocam em relação a ele, se livram dele e o ultrapassam (pág. 233, grifo nosso).

Foucault chamou de dispositivo da sexualidade o conjunto heterogêneo

de discursos, instituições, decisões regulamentares, enunciados científicos, proposições filosóficas e morais que confeririam um lugar especial à sexualidade, como se nela pudéssemos encontrar algo de fundamental acerca da verdade sobre nós mesmos (FOUCAULT, 1998). O mesmo autor prosseguiu, agora encarnando a voz do homossexual:

...está certo, nós somos o que vocês dizem, por natureza, perversão ou doença, como quiserem. E, se somos assim, sejamos assim e se vocês quiserem saber o que nós somos, nós mesmos diremos, melhor que vocês (...) é a inversão estratégica de uma mesma vontade de verdade (pág. 234, grifo nosso). 
Para Foucault, a vontade de verdade é o mais universalizante dos procedimentos de produção e utilização dos discursos. A verdade (científica, por exemplo), que é sempre uma produção de época passível de revisão, norteia outros discursos se tornando paulatinamente naturalizada e inquestionável (TRAVIESO, 2001).

No que chamou de "inversão estratégica", Foucault sustentou que seria possível partir do dispositivo da sexualidade para, dali, iniciar um movimento, lutar por direitos e reinventar a própria existência. Partir de uma característica - a orientação sexual - que teria sido historicamente destacada e alçada à condição de verdade fundamental sobre o sujeito para construir as bases de um movimento social de afirmação. A "inversão estratégica” mencionada por Foucault não teria ocorrido apenas na gênese dos "movimentos de liberação" homossexuais, ela também teria se dado, por exemplo, nos primeiros tempos dos movimentos feministas:

“...os movimentos feministas aceitaram o desafio. Somos sexo por natureza? Muito bem, sejamos sexo em sua singularidade e especificidade irredutíveis. Tiremos disto as consequiências e reinventemos nosso próprio tipo de existência, política, econômica, cultural... (pág. 233, 1998).

Ou seja, a partir de uma "inversão estratégica" de uma mesma "vontade de verdade", o sexo e a orientação sexual (que já haviam sido utilizados para "colonizar" 36 " mulheres e homossexuais) tornar-se-iam bandeiras ao redor das quais os "movimentos de liberação" sexual se constituiriam para, então,

\footnotetext{
${ }^{36}$ Termo utilizado pelo autor (FOUCAULT, 1998).
} 
combater a normatividade, reivindicar direitos e, finalmente, desconstruir suas personagens.

Sempre o mesmo movimento: partir desta sexualidade na qual se procura colonizá-la(o)s e atravessá-la para ir em direção a outras afirmações" (pág. 233, FOUCAULT, 1998).

Entretanto, também podemos considerar que, ao estabelecer esse ponto de partida, os movimentos mencionados por Foucault reiteraram a importância conferida ao sexo, assim como havia sido feito pelos que anteriormente construíram a espécie homossexual. Desse modo, os "movimentos de liberação" homossexual referendaram o lugar central conferido ao sexo, pelo dispositivo da sexualidade, ao fazer da orientação sexual seu marco zero.

Portanto, de forma semelhante ao que ocorreu na construção da espécie homossexual, concordamos com Uziel (2007) que a criação de termos como gays families e famílias homoparentais (que uniram sexualidade e parentalidade em uma mesma expressão) conferiram visibilidade social a essas famílias e mostraram-se úteis para viabilizar a constituição de uma bandeira comum de luta por direitos. Entretanto, também deve-se considerar que adotar uma dessas denominações para se referir a esses arranjos familiares é uma escolha que exige cuidados. 


\section{3 - Uma outra "espécie" de família}

Um dos cuidados a serem adotados relaciona-se ao fato de que, ao utilizarmos termos como gay families ou famílias homoparentais em estudos no campo da saúde, destacamos e valorizamos um aspecto - o sexual - em detrimento de outros ao referirmo-nos à elas. Dessa forma, arriscamo-nos a contribuir inadvertidamente para a criação de uma outra "espécie" de família, com características distintivas relacionadas à orientação sexual do casal parental, de forma análoga ao que ocorreu na construção da "espécie" homossexual (FOUCAULT, 2001), que contou com a participação direta de médicos e psicólogos. Uma espécie de família, convém mencionar, que seria desvalorizada e deficitária quando comparada à outras configurações familiares.

Alguns de nossos entrevistados, de fato, esboçaram a construção de uma hierarquia ${ }^{37}$ ao compararem as suas famílias com outras. Nessa hierarquia, foram concedidos lugares menos valorizados às famílias homoparentais do que às famílias heterossexuais e aos "negros", por um lado; e mais valorizados do que os que transformistas, transexuais, travestis, drogados, michês, por outro.

Creio que a construção de teorias que descrevam a homoparentalidade como uma outra espécie de família, marcada pela desvalorização, a

\footnotetext{
${ }^{37}$ A construção de uma hierarquia das famílias (que valoriza determinadas configurações em detrimento de outras) não se restringe ao que disseram nossos entrevistados, pois também se verifica no discurso religioso, por exemplo, que enaltece e naturaliza um modelo específico de configuração familiar.
} 
doença/perversão do casal parental, pelo déficit ou pela incapacidade de cuidar adequadamente de uma prole, não seja uma possibilidade remota quando referimo-nos especificamente ao campo da Psicologia ou à área da saúde. Basta lembrar que vários dos primeiros estudos conduzidos por psicólogos a respeito dessas famílias investigavam a possibilidade de que seus filhos pudessem apresentar déficits, quando comparados aos filhos de famílias heterossexuais, justamente por serem filhos de casais gays ou de lésbicas. Por ora não nos importa analisar os resultados daqueles estudos (uma boa revisão da literatura a esse respeito pode ser encontrada em Patterson, 1992), o que se deseja é somente destacar a hipótese que a temática dos mesmos permitiu-nos inferir, ou seja: que a orientação sexual dos pais pudesse ser o suficiente para gerar uma prole com problemas, como se essas fossem, de fato, uma espécie de famílias à parte.

Cabe mencionar também que alguns de nossos entrevistados referiramse aos seus filhos demonstrando uma preocupação semelhante, como se eles pudessem apresentar algum tipo de diferença (via de regra indesejável) em relação aos filhos de casais heterossexuais. Dessa forma, seus discursos reeditaram uma expectativa que, de fato, já se fazia presente nas hipóteses de trabalho dos psicólogos de décadas passadas.

Alguns autores afirmam que parte da comunidade psicanalítica teria contribuído para associar o homossexual à doença e à perversão (ROUDINESCO, 2003; COSTA, 1998; MELLO, 2005; GRAÑA, 1998), o que teria redundado em debates acalorados sobre a sua aceitação ou rejeição 
quando estes se candidatavam à formação psicanalítica inclusive no Brasil (ZIMERMAN, 1999), na criação e difusão de técnicas terapêuticas “conversivas"38, na crítica à concessão do status jurídico de família aos homossexuais $^{39}$, e na defesa de que o direito à adoção fosse judicialmente vedado aos membros de famílias homoparentais, como fez o psiquiatra e psicanalista Cláudio Pérsio Carvalho Leite na Comissão Especial que avaliou o Projeto de Lei 1.151/95 na Câmara dos Deputados (MELLO, 2005).

Vários médicos também participaram ativamente da invenção do homossexual como uma espécie anormal, bem como das diversas tentativas de transformar sua orientação sexual. Clínicos criaram estratégias de trabalho com o objetivo declarado de reconduzir os homossexuais à "normalidade" heterossexual e o leitor que se dispuser a ler a respeito dessas estratégias choques, lobotomias, terapias de aversão, terapias de conversão, dentre outras - irá deparar-se com relatos que mostram que o discurso científico já serviu para justificar a tortura física e psicológica, bem como para estigmatizar os que não aceitaram submeter-se às regras de uma moral sexual restritiva (FOUCAULT, 2001; GRAÑA, 1998; ROUDINESCO, 2003 e 2008).

Parte dos terapeutas familiares teria ignorado por anos essas famílias em seus estudos até meados da década passada ou, quando isso não se deu, teriam se mostrado críticos em relação às propostas de revisões conceituais acerca da eleição de um modelo específico - o nuclear patriarcal - em

\footnotetext{
${ }^{38}$ Apesar dos protestos de figuras ilustres, como Freud, Ferenczi, Stoller e outros (GRAÑA, 1998).

${ }^{39}$ Como no caso, entre outros psicanalistas franceses, de Pierre Legendre, psicanalista, antigo membro da EFP e diretor de estudos honorário da École Pratique des Hautes Études, seção V, na França (ROUDINESCO, 2003)
} 
detrimento de outros, como sinônimo da família que seria capaz de gerar e criar filhos autônomos e emocionalmente estáveis (CLARK E SEROVICH, 2007; MALLEYA E TASKERB, 1999; NICHOLS \& SCHWARTZ, 1998).

Tendo em vista esse histórico e o lugar o ocupado por parte das teorias psicológicas e médicas na construção da espécie homossexual, bem como o risco de que o presente estudo também possa ser utilizado ${ }^{40}$ para referendar a idéia de que essas sejam, de fato, uma outra espécie de famílias, entendo ser imprescindível destacar alguns aspectos relativos às condições da produção discursiva de nossos entrevistados. Afinal, como afirmei em um trabalho anterior, inspirado em Foucault:

As condições que possibilitam a produção das formações discursivas relacionam-se intimamente a tempos e espaços específicos, datados e circunscritos (geográfica e socialmente). Conceber as formações discursivas, do modo como o faz Foucault, significa entender ser possível buscar no âmbito discursivo as condições de sua possibilidade e admitir que essas referem-se sempre a uma ampla gama de regramentos que, em certa medida, condicionam e estabelecem o que é possível e o que não é possível dizer (TOLEDO, 2003).

Ou seja, os discursos tem uma história, uma origem e um contexto social e geográfico, e esses aspectos condicionam o que é ou não é possível dizer sobre quaisquer temas. Portanto, com o intuito de discorrer sobre as condições dessa produção discursiva, retomaremos brevemente as nossas análises para, então, prosseguir destacando algumas marcas de sua construção. 


\section{4 - A trajetória dos entrevistados}

Nossos entrevistados discorreram sobre suas famílias atuais e sobre a família (citada de forma abrangente ${ }^{41}$ ) mencionando a intensidade dos sentimentos amorosos que marcaram o início das relações com seus parceiros (que por vezes causaram surpresa e desnorteamento) e a rapidez com que decidiram morar junto com aqueles. Essa decisão de morar com os parceiros foi descrita menos como um ato de vontade e mais como um impulso irrefreável capaz de conduzir à ação. Um impulso que, convém mencionar, a história de luta política permitiu transformar em ato.

No que diz respeito aos aspectos mais valorizados de seus relacionamentos amorosos, destacaram a presença constante dos parceiros em diversos momentos de suas vidas e a segurança de poderem contar com sua solidariedade e auxílio emocional e financeiro, tanto nos bons quanto nos maus momentos.

Todos afirmaram que desejam ou desejaram (alguns já haviam realizado esse desejo) ser pais e que os filhos seriam uma necessidade ou um aspecto fundamental da família, pois conferiria um sentido à existência da mesma. Questionados sobre os aspectos que levariam em conta para nortear suas escolhas em eventuais processos de adoção, citaram predominantemente os sentimentos (de carinho, amor, afeição) despertados no encontro com a criança ou o jovem a ser adotado e, eventualmente, o sexo biológico (a

\footnotetext{
${ }^{40}$ À revelia do seu autor.

${ }^{41}$ Em resposta à questão: o que é família para você?
} 
preferência recaiu sobre as meninas), a faixa etária, características físicas e o estado de saúde.

No entanto, o discurso de nossos entrevistados sobre a família, a parceria amorosa e os filhos também foi acompanhado, de forma marcante, pela defesa da normalidade de si mesmos (bem como de suas famílias atuais e de seus filhos), pelo temor e a expectativa de que a exposição de sua orientação sexual e/ou de sua parceria amorosa pudessem redundar em rejeição, em hostilidades ou na sua exclusão por parte da (ou por toda a) sociedade. Essas expectativas de exclusão e rejeição (e as menções às ocasiões nas quais a mesma expectativa confirmou-se) se fizeram presentes quando os entrevistados referiram-se a suas famílias de origem, aos colegas de trabalho e as suas relações com líderes religiosos. O temor da rejeição mostrou-se ainda mais abrangente e generalizado, estendendo-se também às relações com juízes, psicólogas, gerente de banco, dentre outros.

No que diz respeito aos filhos, os entrevistados mostraram-se preocupados de que esses sofressem conseqüências indesejáveis, como hostilidades, preconceito e rejeição em decorrência do fato de serem filhos de famílias homoparentais. Também manifestaram o receio de que os filhos se voltassem contra eles - os pais - no futuro.

Nesse sentido, estabeleceu-se uma lógica nos discursos analisados segundo a qual estabelecer uma família homoparental e/ou falar abertamente sobre sua orientação sexual os colocaria em risco de formas variadas. Esses riscos se refeririam à possibilidade de perder o respeito, o amor e a 
consideração dos membros de suas famílias de origem, o emprego e a filiação a uma instituição religiosa. Ou seja, formar ou fazer parte de uma família homoparental poderia acarretar em exclusão e rejeição social. A exclusão e a rejeição nem sempre se confirmaram. Entretanto, quando nossos entrevistados mencionaram situações nas quais elas não ocorreram, eles se mostraram surpresos, o que nos permitiu inferir que essa não seria a expectativa predominante.

Entretanto, como já afirmamos, uma análise de discurso não se restringe ao que disseram os entrevistados, pois os discursos são produções e as condições que permitem que essas se façam referem-se a momentos históricos, contextos sociais e institucionais específicos. Ou seja, os discursos carregam marcas de sua época e das condições de enunciação oferecidas pela mesma. Nesse sentido, entendemos que se faz necessário considerar as condições de enunciação na qual nossos entrevistados construíram seus discursos ressaltando que, no que se refere à temática aqui debatida, essas condições tem se modificado significativamente nos últimos anos.

Feitas essas considerações, o que se pode afirmar é que esses discursos sobre as famílias homoparentais brasileiras foram construídos em um contexto social, jurídico, político e científico que, em parte, finalmente reconhece sua existência e lhes proporciona visibilidade e (em alguns casos) legitimidade. Dentre outros aspectos, sua existência é reconhecida porque já existem jurisprudências e processos judiciais nos quais suas demandas foram avaliadas e (por vezes) deferidas. Também já foram realizadas pesquisas científicas no 
Brasil acerca dessas famílias (como as de UZIEL, 2007; MOSCHETA, 2004; MELLO, 2005) e o IBGE as mencionou recentemente no contexto de uma ampla pesquisa populacional. Algumas instituições religiosas se opuseram publicamente ao reconhecimento oficial das mesmas por parte do governo (e, ao fazê-lo, reconheceram sua existência). As famílias homoparentais foram, ainda, tema de uma Parada Gay em 2004 que reuniu milhares de pessoas na principal capital do país exigindo reconhecimento social e a garantia de seus direitos, conferindo visibilidade ao tema. Em meio a um cenário social marcado por embates com aqueles que, de fato, a rejeitaram, os defensores dos direitos à homoparentalidade vêm obtendo algumas vitórias no Brasil e no mundo.

Entretanto, parte dos discursos sobre a homoparentalidade proferidos por religiosos, políticos, membros do judiciário e profissionais de saúde, incluindo os psicólogos, não lhes foi (nem é) favorável. Além disso, o reconhecimento formal dessas famílias por parte do Estado brasileiro não está consolidado, e, quando se dá, segue sendo precário. Basta afirmar que não existem leis que lhes garantam o status de família no país, apenas algumas decisões favoráveis em tribunais superiores.

Assim, nossos entrevistados discorreram sobre as suas famílias em oposição a outras vozes que freqüentemente foram hostis à sua existência e reconhecimento social, que afirmam (afirmaram) sua anormalidade e que supõe (supuseram) déficits em seus filhos em conseqüência da homoparentalidade do casal parental. 
É preciso considerar que esse cenário, marcado pelo embate entre vozes, não se restringe ao que foi possível depreender dos discursos aqui analisados, pois ele se verifica nos âmbitos social e político no Brasil. Ou seja, atravessamos um momento histórico no qual, se por um lado elas finalmente dispõem de algumas condições de existência e visibilidade, por outro seguem sem garantias definitivas quanto aos seus direitos, desaprovadas por várias instituições, bem como por aqueles que se apegam à idéia de uma família e de uma sexualidade natural, como sustentado por Mello (2002).

Assim, o cenário discursivo descrito no capítulo de análises desse trabalho, marcado, dentre outros aspectos: pela expectativa de rejeição e exclusão, pela necessidade de afirmar a normalidade de si mesmos, de suas famílias e de seus filhos, pela acentuada assimetria de poderes $^{42}$, pela descrição da orientação sexual como um aspecto fundamental da verdade de si mesmos, pela associação entre homossexualidade e promiscuidade, pela construção de uma hierarquia familiar, pelo receio de que os filhos sofressem consequiências em decorrência da orientação sexual dos pais, dentre outros, encontram as bases de sua fundação e organização em um cenário social de embates, luta por direitos e organização política que inclui as vozes dos religiosos, políticos, médicos, psicanalistas e psicólogos que se dispuseram a tratar da temática da homossexualidade e homoparentalidade no Brasil e em outros países.

${ }^{42}$ Entre os membros de famílias homoparentais e os juízes, psicólogos, gerentes de banco, etc. 
No discurso se constroem e reproduzem lugares, sentidos e expectativas. Como afirmaram Maingueneau e Ducrot, várias vozes podem ser distinguidas no discurso de um mesmo falante e, como afirmou Guirado, as amarrações ou as reconstruções a que se chega realizando uma análise de discurso:

...acabam falando ao mesmo tempo dos autores das cenas enunciativas e das condições de enunciação. Aí, a metáfora da "dobradiça"; ou melhor, de um "conceito-dobradiça" de sujeito (pág. 89, 1995).

Creio que a Psicologia e suas ramificações tiveram e seguirão tendo papéis destacados no que se refere à configuração das condições de enunciação a respeito dessa temática. O discurso jurídico se serve da psicologia, dentre outros, para embasar suas decisões sobre adoção por casais homoparentais e, como vimos no início dessa tese, a psicanálise e o psicodrama foram chamados a participar diretamente dos debates sobre o projeto de Lei 1.151 na Comissão Especial na Câmara dos Deputados, em Brasília.

Por isso não seria prudente encerrar essa discussão sem discorrer (mesmo que de modo breve) a respeito da psicologia e dos profissionais da área, ressaltando a necessidade premente de se produzir e trabalhar nesse campo, bem como destacando os perigos de fazê-lo. 


\section{5 - A Psicologia diante da homoparentalidade}

Sabemos que o discurso científico já foi utilizado para justificar ou recomendar a exclusão, a rejeição, o encarceramento e a dominação, não apenas daqueles cuja orientação sexual não seguiram os parâmetros de uma normalidade restritiva, mas também dos loucos, das prostitutas, dos judeus, dos portadores de doenças sexualmente transmissíveis, dentre outros (FOUCAULT, 2001; ROUDINESCO \& PLON; 1998, COSTA, 1976). Assim, para os que pretendem realizar pesquisas ou trabalhar com essas famílias no campo da Psicologia e não tem a intenção de contribuir para a construção de uma outra espécie de família (colaborando para exclusão e a discriminação), colocam-se algumas questões: Como construir pesquisas a respeito dessas famílias sem estigmatizá-las? Como criar práticas psicoterapêuticas que atendam às suas demandas e não se pautem por noções normativas de família? Ou que não contribuam para torná-las uma outra espécie? Ou que não reiterem a crença de que no sexo do casal parental reside uma verdade fundamental (e indesejável) capaz de obscurecer outros aspectos dessas famílias?

Não creio que as respostas a essa perguntas estejam dadas de antemão, mas entendo que alguns cuidados possam ser adotados no que diz respeito às pesquisas acadêmicas e às práticas terapêuticas voltadas às famílias homoparentais. Sucintamente compreendo que seria recomendável: assumir e pressupor a diversidade dessas famílias, considerar e descrever as adversidades enfrentadas por elas e compreender os vários aspectos do 
contexto social no qual elas vem ganhando visibilidade. Também creio ser indispensável considerar as repercussões sociais, políticas e psíquicas desse contexto histórico ao produzir pesquisas e práticas sobre essas famílias.

Esse último requisito - o contexto histórico da produção discursiva parece particularmente relevante, pois um autor que não o considere detidamente correria o risco (por exemplo) de apontar no intenso temor de rejeição e exclusão, tão marcante nos discursos analisados, os sinais de um discurso paranóico. De fato, a paranóia já foi mencionada anteriormente por psiquiatras brasileiros como um traço distintivo dos homossexuais, como mencionado por Fry (1982). Alijado de sua história e do contexto social que o cerca, o excluído corre o risco de ser descrito como paranóico pela vontade de verdade $^{43}$ psicopatológica. Entendo, portanto, que descrever e considerar o contexto social e histórico é fundamental para, dentre outros, diferenciar sintomas de relatos sobre exclusão e perseguição social.

No que se refere às terapias, entendo que abordagens que partam de concepções essencialistas sobre como deve ser a configuração e organização de uma família, ou sobre como deve ser a distribuição de atribuições e poderes no âmbito familiar, provavelmente serão pouco úteis ou pouco éticas. Nesse sentido, os terapeutas que estiverem atentos a esses aspectos poderão construir abordagens mais respeitosas, menos normativas e capazes de acolher as diferenças.

${ }^{43}$ No sentido foucaultiano (1999). 
Assim como Roudinesco (2003), também considero necessário destacar que os filhos dessas famílias provavelmente enfrentarão dificuldades no correr de suas vidas, não por serem filhos daqueles que tantas vezes foram descritos como doentes, pecadores ou criminosos, mas por terem nascido em sociedades (como a brasileira) nas quais a relação de seus pais é controversa ${ }^{44}$ e a legitimidade de suas uniões e de sua filiação não está plenamente garantida por lei.

No que diz respeito ao uso de uma terminologia específica para designá-las, talvez seja conveniente, do ponto de vista daqueles que lutam pela conquista de direitos, seguir se referindo à elas como homoparentais ou gay families, já que algumas das conquistas sociais no campo ocorreram após o (e também em função do) surgimento e do adensamento daqueles que Parker chamou de movimentos da política de identidade gay (2002). Ou seja, talvez seja inevitável correr alguns dos riscos já descritos nesse capítulo (ao menos durante algum tempo), já que fazê-lo parece ter sido fundamental para possibilitar tanto a "inversão estratégica" descrita por Foucault (1998), quanto a formação dos movimentos de política de identidade mencionados por Parker $^{45}$. Mas isso não implica em afirmar que essas denominações não possam ou não devam ser abandonadas posteriormente. Foucault considerava, como mencionado no início desse capítulo, que chegaria o momento no qual seria possível e desejável que os participantes dos "movimentos de liberação

\footnotetext{
${ }_{44}^{44}$ Como ocorria na década de setenta com as famílias divorciadas (MELLO, 2005).

45 Nas quais o destacamento do aspecto sexual foi relevante para aglutinar indivíduos que se dispuseram a lutar juntos por mudanças sociais e legislativas que poderiam beneficiar a todos.
} 
sexual" atravessassem e (acrescento) ultrapassassem o dispositivo da sexualidade para seguir adiante, em direção a outras afirmações (1998). A afirmação social da homoparentalidade talvez seja uma das etapas desse processo.

Pode ser mais prudente, portanto, prosseguir referindo-se a elas como homoparentais, utilizando o plural, destacando desse modo a diversidade dessas famílias, mas tendo o cuidado de ressaltar que algo as une atualmente: um contexto social e histórico que lhes é, sob vários aspectos, desfavorável. Mas que, convém ressaltar, está se transformando rapidamente.

Finalmente, concordando com Sylvia Leser de Mello (2002), admito que:

...as idéias de uma sexualidade natural, de um parentesco natural e de uma família natural fazem parte de nossa imaginação e estão há longo tempo fixadas pela socialização e pela educação familiares... (pág. 17)

Suponho, ainda, que essa naturalização das idéias de sexualidade, parentesco e família também se fizeram (e fazem) presentes de formas variadas na história de teorias e práticas do campo da psicologia, colaborando para justificar a estigmatização e a patologização dos que não se enquadram nos padrões de uma sexualidade normativa. Por isso, entendo que caberia aos profissionais de saúde, psicólogos incluídos, rever as teorias já formuladas a respeito das temáticas que se relacionam à homossexualidade e à homoparentalidade, bem como as práticas terapêuticas destinadas a atenção à essas famílias, considerando que as teorias psicológicas também são formações discursivas que carregam as marcas de sua época e do contexto no qual foram 
criadas, sendo, portanto, passíveis de revisão e reformulação. Essa revisão, bem como a criação de novas práticas e teorias poderia se inspirar na crítica ao essencialismo, contribuindo para a desconstrução da idéia de uma família e de uma sexualidade naturais, bem como concedendo uma atenção redobrada à normatividade que por vezes caracteriza a vontade de verdade científica, tal como formulada por Foucault (1999).

Dessa forma, talvez possamos contribuir para a criação de uma história diferente e melhor, não apenas para as famílias homoparentais, mas para a própria Psicologia. 


\section{CONSIDERACÕES FINAIS}

Afirmamos, no capítulo de discussão, que o homossexual foi transformado em uma "espécie" doente, desvalorizada, promíscua e deficitária pela psiquiatria e a sexologia após 1870 . No sexo se encontraria a verdade dessa espécie, pois nada daquilo que ele - homossexual - é escaparia à sua sexualidade. Cem anos se passaram até que, nos anos setenta do século passado, alguns autores, dentre eles Foucault (2001), iniciaram a desconstrução dos discursos sobre o homossexual, evidenciando os jogos de poder envolvidos em sua conceituação.

Nos anos seguintes a homossexualidade deixou de ser considerada uma doença nos manuais de psicopatologia e as associações de psicólogos e médicos em várias partes do mundo firmaram posições contra a discriminação da diversidade sexual.

No final da década de noventa do século passado os franceses criaram o termo homoparentalidade para designar as famílias e as futuras famílias homossexuais. Nos Estados Unidos, os estudiosos preferiram utilizar o termo gay families para se referir às mesmas. A homoparentalidade se tornou uma bandeira de luta, sendo escolhida como tema de uma Parada Gay que reuniu milhares de pessoas em São Paulo em 2004. Essas famílias ganharam visibilidade mundial e obtiveram vitórias importantes em vários países na conquista de direitos à união estável, adoção, transmissão de heranças, dentre outros. 
No que diz respeito à Psicologia, ressaltamos que referir-se à elas utilizando termos que destacam a orientação sexual do casal parental é uma escolha que implica em riscos. Um desses riscos seria o de contribuir para a construção de uma outra espécie de família (doente, menos valorizada, deficitária), como ocorreu anteriormente com a criação da espécie homossexual.

Também sustentamos que, ao nos debruçarmos sobre o que haveria de comum nos discursos sobre a família proferido por nossos entrevistados, seria possível indicar que a construção discursiva desses se deu em oposição a outros discursos (religiosos, jurídicos, médicos, psicológicos) que questionam sua normalidade, temendo a rejeição, a exclusão social e a discriminação decorrentes da exposição pública da homoparentalidade, bem como receosos de que sua prole sofresse conseqüências indesejáveis em decorrência da orientação sexual dos pais.

Também afirmamos que o discurso de nossos entrevistados foi construído em um momento social, histórico e político que, se por um lado lhes concede visibilidade e (eventualmente) reconhecimento estatal, por outro lhes é abertamente desfavorável.

Apesar da cautela, afirmamos que talvez seja importante prosseguir nos referindo à elas (ao menos temporariamente) como homoparentais, afirmando sua diversidade e escrevendo a seu respeito, pois a visibilidade conferida pela nomeação dessas famílias tem tido um papel importante na luta por direitos, 
bem como na consolidação e no adensamento de movimentos de liberação sexual.

Será prudente, entretanto, redobrar as atenções para o modo como nos referiremos à homoparentalidade para que não façamos dela um diagnóstico ou um sinônimo de família disfuncional. Nesse sentido, faz-se imprescindível ressaltar as condições sociais, históricas, políticas e científicas nas quais os membros dessas se encontram imersos, considerando que o discurso dos mesmos carregará inevitavelmente as marcas das condições de enunciação oferecidas por sua época. 


\section{REFERÊNCIAS BIBLIOGRÁFICAS:}

ANDERSSEN, N.; AMLIE, C.; YTTERØY, E. A. Outcomes for children with lesbian or gay parents: a review of studies from 1978 to 2000. Scandinavian Journal of Psychology, 43, 335-351, 2002. em:

ASSOCIAÇÃO da Parada do Orgulho GLBT de São Paulo. Disponível $<$ http://www.paradasp.org.br/modules/news/article.php?storyid=463>. Acesso em: 07 out. 2003.

A UNICAMP e Campinas. Disponível em:

http://www.unicamp.br/unicamp/a_unicamp/a_unicamp_cidades_campinas.ht ml. Acesso em: 10, mai, 2008.

BERQUÓ, E. Arranjos familiares no Brasil: uma visão demográfica. In SCHWARCZ, L. M. (org..) História da vida privada no Brasil: contrastes da intimidade contemporânea. Vol. 4. São Paulo: Cia das Letras, 1998.

BOSWELL, J. Christianity, Social Tolerance, and Homosexuality: Gay People in Western Europe from the Beginning of the Christian Era to the Fourteenth Century. Chicago: University of Chicago Press, 2005.

BRASIL. Instituto Brasileiro de Geografia e Estatística. Pesquisa nacional por amostra de domicílios - 2001. Tabela 6.3. Rio de Janeiro, 2002. Disponível em:

<http://www.ibge.gov.br>. Acesso em: 07 out. 2003.

BRASILÍA. Secretaria de Imprensa da Presidência da República. Discurso do presidente da República, Luiz Inácio Lula da Silva, na solenidade de abertura da I Conferência Nacional de Gays, Lésbicas, Bissexuais, Travestis e Transexuais - GLBT. Disponível em:

$<$ http://imprensa.planalto.gov.br/download/discursos/pr714-2@.doc>. Acesso em: 14 jul. 2008.

CASTELLS, M. O poder da identidade: Volume 2 (A era da informação: economia, sociedade e cultura). São Paulo: Paz e Terra, 2000.

CHASSEGUET-SMIRGEL, J. Ética e estética da perversão. Porto Alegre: Artes Médicas, 1991.

CÍRIO de Nazaré leva 2 milhões de fiéis para as ruas de Belém, 2007. Disponível em: 
<http://www1.folha.uol.com.br/folha/brasil/ult96u336654.shtml> Acesso em: 14 out. 2007.

CLARCK, W; SEROVICH, M. Twenty years and still in the dark? Content analysis of articles pertaining to gay, lesbian, and bisexual issues in marriage and family therapy journals. Journal of Marital and Family Therapy. Vol 23, Issue 3, 2007.

COMISSÕES, 2008. Disponível em: <http://www.crp06.org.br/a_comis/set_glbtt.htm> Acesso em: 24 mai. 2008.

CONFERÊNCIA, 2008. Sobre a conferência: a Conferência. Disponível em:

$<$ http http://www.conferencianacionalglbt.com.br/sobreConferencia.php $>$ Acesso em: 13 jul. 2008.

CONGREGAÇÃO, 2003. Considerações sobre os projectos de reconhecimento legal das uniões entre pessoas homossexuais. Disponível em: $<$ http://www.vatican.va/roman_curia/congregations/cfaith/documents/rc_con_ cfaith_doc_20030731_homosexual-unions_po.html> Acesso em: 13 jul. 2008.

CONTAGEM, 2007. Disponível em:

$<$ http://www.ibge.gov.br/home/estatistica/populacao/contagem2007/default.sh tm> Acesso em: 06 jun 2008.

COSTA, J. F. História da Psiquiatria no Brasil: um corte ideológico. Rio de Janeiro: editora Documenta, 1976.

COSTA, J. F. A inocência e o vício: estudos sobre o homoerotismo. Rio de Janeiro: Relume-Dumará, 1992.

COSTA, J. F. A questão psicanalítica da identidade sexual. In GRAÑA, R. Homossexualidade: formulações psicanalíticas atuais. Porto Alegre: Artes Médicas, 1998.

COSTA, J. F. Ordem médica e norma familiar. Rio de Janeiro: Edições Graal, 1999.

DIMENSTEIN, G. Decisões judiciais favorecem homossexuais, 2003. Disponível em:

<http://www1.folha.uol.com.br/folha/dimenstein/imprescindivel/semana/gd14 0102a200102.htm>. Acesso em: 07 out. 2003.

DINIZ, M. H. Dicionário Jurídico.Vol. 4. São Paulo: Saraiva, 1998. 
ESPÍNDOLA, R. E. Famílias Homoparentais: (pré) conceitos dos (as) alunos(as)-professores(as) de educação infantil e séries iniciais do ensino fundamental. Santa Catarina, 2005. Mestrado (Dissertação). Universidade do Vale do Itajaí.

FOLHA, Cotidiano. Justiça autoriza casal gay a adotar criança no interior de SP, 2006. Disponível em:

$<$ http://www1.folha.uol.com.br/folha/cotidiano/ult95u128520.shtml>. Acesso em: 25 mai. 2008.

FOLHA, Religião. Vaticano faz ofensiva contra "cultura gay", 2006. Disponível em:

< http://www1.folha.uol.com.br/fsp/mundo/ft2102200605.htm>. Acesso em: 13 jul. 2008.

FOLHA, Mundo. Colômbia reconhece direitos de casais gays, 2007. Disponível em:

< http://www1.folha.uol.com.br/folha/mundo/ult94u304924.shtml>. Acesso em: 07 jun. 2008. 1998.

FOUCAULT, M. Microfísica do poder. Rio de Janeiro, Edições Graal,

FOUCAULT, M. A Ordem do Discurso. São Paulo, Edições Loyola, 1999.

FOUCAULT, M. História da sexualidade: a vontade de saber. Rio de Janeiro: Edições Graal, 2001.

FREUD, S. Três ensaios sobre a teoria da sexualidade. (1905). In: Obras Completas. Rio de Janeiro, Imago, 1980, vol. VII.

FRY, P. Para inglês ver: identidade e política na cultura brasileira. Rio de Janeiro: Zahar Editores, 1982.

G1, Arquivo: Comício das 'Diretas Já' em SP. Disponível em: $<$ http://g1.globo.com/Noticias/Politica/0,,MUL22424-5601,00.html>. Acesso em: 22 mai. 2008.

G1, Edição São Paulo.Casal gay consegue paternidade de criança no interior de São Paulo, 2006. Disponível em:

< http://g1.globo.com/Noticias/SaoPaulo/0,,AA1358986-5605,00.html>. Acesso em: 08 jun. 2008. 
G1, Edição São Paulo.São Paulo terá primeiro casamento gay do Brasil, $2006 . \quad$ Disponível em: < http://g1.globo.com/Noticias/SaoPaulo/0,,MUL364239-5605,00.html>. Acesso em: 08 jun. 2008.

GOFFMAN, E. Estigma: notas sobre a manipulação da identidade determinada. Rio de Janeiro: Zahar Editores, 1980.

GRAÑA, R. Violência e sexuação: sobre algumas possíveis impropriedades da clínica psicanalítica In GRAÑA, R. Homossexualidade: formulações psicanalíticas atuais. Porto Alegre: Artes Médicas, 1998.

GRODDECK, G. O livro Disso. São Paulo: Editora Perspectiva, 1997.

GUIRADO, M. Instituição e relações afetivas: o vínculo com o abandono. São Paulo: Summus, 1986.

GUIRADO, M. Psicanálise e análise de discurso. São Paulo: Summus, 1995.

GUIRADO, M. A clínica psicanalítica na sombra do discurso: diálogos com aulas de Dominique Maingueneau. São Paulo: Casa do Psicólogo, 2000.

GUIRADO, M.; LERNER, R. (orgs.) Psicologia, pesquisa e clínica: por uma análise institucional do discurso. São Paulo: Fapesp/Annablume, 2007.

HEILBORN, M. L.; BRANDÃO, E. R. Ciências sociais e sexualidade. In: HEILBORN, M. L. (Org.). Sexualidade: o olhar das ciências sociais. Rio de Janeiro, Jorge Zahar Ed., 1999.

HEILBORN, M. L. Dois é par: conjugalidade, gênero e identidade sexual em contexto igualitário. Rio de Janeiro: UFRJ/Museu Nacional, 1992.

HISTÓRICO das Paradas em São Paulo. Disponível em: $<$ http://www.paradasp.org.br>. Acesso em 24 jan. 2007.

IBDFAM, Projeto garante psicólogo para quem deixar homossexualismo, 2005. Disponível em: $<$ http://www.ibdfam.org.br/?noticias\&noticia=546>. Acesso em 07 set. 2008.

KAPLAN, H. I.; SADOCK, B. J.; GREBB, J. A. Compêndio de psiquiatria: ciências do comportamento e psiquiatria clínica. Porto Alegre: Artes Médicas, 1997. 
LERNER, R. Instituições: da psicanálise na ordem do discurso de agentes de saúde mental. São Paulo, 1999. Dissertação (Mestrado) - Instituto de Psicologia, Universidade de São Paulo.

MAINGUENEAU, D. Novas Tendências em Análise do discurso. Campinas, Pontes, 1989.

MALLEYA, M. TASKERB, F. Lesbian, gay men and family therapy: a contradiction in terms? Journal of Family Therapy. Volume 21. Issue 1. Pages 3-29, 16 dez., 2002.

MELLO, S. L. Família, uma incógnita familiar. In AGOSTINHO, M. L.; SANCHEZ, T. M. (Orgs), Família: conflitos, reflexões e intervenções. São Paulo: Casa do Psicólogo, 2002

MOORE, H. Understanding sex and gender in Companyon Encyclopedia of Anthropology. Londres, Routledge, 1997. Tradução de Júlio Simões.

MOSCHETA, M. S. Construindo a diferença : a intimidade conjugal em casais homens homossexuais. Ribeirão Preto, 2004. Dissertação (Mestrado) - Faculdade de Filosofia, Ciências e Letras, Universidade de São Paulo.

MOTT, L. Sexo proibido: virgens, gays e escravos nas garras da inquisição. Campinas: Papirus, 1989.

NATIVIDADE, M. T.; LOPES, P. V. L. Os direitos das pessoas GLBT e as respostas religiosas: da parceria civil à criminalização da homofobia. In Duarte et al. Entre o público e o privado. A influência dos valores religiosos na tramitação de Projetos de Lei no Brasil. Relatório de Pesquisa. São Paulo: PROSARE/CCR/MacArthur, mimeo, 2007.

NATIVIDADE, M. T. Acima dos direitos sexuais está a Bíblia? Respostas de segmentos conservadores à diversidade sexual. Disponível em: $<$ http://www.clam.org.br>. Acesso em 12 ago. 2008.

NICHOLS, M. P.; SCHWARTZ, R. C. Terapia familiar: conceitos $e$ métodos. Porto Alegre: Artes Médicas, 1998.

O GLOBO. Casal gay ganha guarda de quatro irmãos em Ribeirão Preto, 2007. Disponível em: <http://oglobo.globo.com/sp/mat/2007/05/13/295738390.asp>. Acesso em 24 mai. 2008. 
O GLOBO. Papa reforça posição sobre casamento gay, liberado na Califórnia, 2008. Disponível em:

<http://oglobo.globo.com/mundo/mat/2008/05/16/papa_reforca_posicao_sobre _casamento_gay_liberado_na_california-427412834.asp >. Acesso em 08 jun. 2008.

PAIVA, V. S. F. Sobre o direito ao amor: a sexualidade e a vontade de ter filhos entre pessoas vivendo com HIV. São Paulo, 2007. Tese (Livre Docência) - Instituto de Psicologia, Universidade de São Paulo.

PARKER, R. G. Na contramão da AIDS: sexualidade, intervenção, política. São Paulo: ed. 34, 2000.

PARKER, R. G. Abaixo do equador. Rio de Janeiro: Record, 2002.

PATTERSON, C. J. (1992) Children of lesbian and gay parents. Child Development, 63, 1025-1042; 1992.

PAULO, B M. Novas configurações familiares e seus vínculos sócioafetivos. Rio de Janeiro, 2006. Dissertação (Mestrado). Pontifícia Universidade Católica.

PERLONGHER, N. O negócio do michê: prostituição viril em São Paulo. São Paulo: Brasiliense, 1987.

PONCIANO, E. L. T.; FÉRES-CARNEIRO, T. Modelos de família $e$ intervenção terapêutica. São Paulo: Interações, vol. 8, 2003

PROPOSTAS em tramitação. Disponível em: <http://www.ggb.org.br/brasil.html>. Acesso em 07 out. 2003.

RAUPP, R. Para um direito democrático da sexualidade. Disponível em:

<http://www.clam.org.br>. Acesso em 25 fev. 2008.

RESOLUÇÃO, 1999. Disponível em:

<http://www.pol.org.br/legislacao/doc/resolucao1999_1.doc>. Acesso em 10 mai. 2008.

ROCK in Rio. Disponível em: < pt.wikipedia.org/wiki/Rock_in_Rio>. Acesso em 10 mai. 2008.

ROUDINESCO, E. A parte obscura de nós mesmos: uma história dos perversos. Rio de Janeiro: Jorge Zahar Ed., 2008. 
ROUDINESCO, E. A família em desordem. Rio de Janeiro: Jorge Zahar Ed., 2003.

ROUDINESCO, E.; PLON, M. Dicionário de Psicanálise. Rio de Janeiro, Jorge Zahar Ed., 1998.

SAMARA, E. M. O que mudou na família brasileira? (da colônia à atualidade). In Psicologia USP, 13 (2), 27-48; 2002.

SANTOS, C. A parentalidade em famílias homossexuais com filhos: um estudo fenomenológico da vivência de gays e lésbicas. Ribeirão Preto, 2005. Tese (Doutorado) - Faculdade de Filosofia, Ciências e Letras, Universidade de São Paulo.

SCOTT, J. Gênero: uma categoria útil de análise histórica in LOPES, E. M. T., LOURO, G. L. Educação e realidade. Número especial Mulher e educação. Porto Alegre, vol. 15, n. 2 jul/dez,1990.

STRAUSS, L. As estruturas elementares do parentesco. Rio de Janeiro: Editora Vozes, 2003.

TARNOVSKY, F. L. Pais assumidos: adoção e parentalidade homossexual no Brasil contemporâneo. Santa Catarina, 2002. Dissertação (Mestrado) UFSC.

TOLEDO, L. C. C. Diálogos familiares sobre a loucura. São Paulo: Vetor, 2006.

TRAVIESO, P. O sujeito no discurso jurídico das varas de infância e juventude. Dissertação (Mestrado), Instituto de Psicologia, Universidade de São Paulo, 2001.

UZIEL, A. P. Reflexões sobre a parceria civil registrada no Brasil. Sexualidade, Gênero e Sociedade, IMS/UERJ, no. 11, julho, pp.1, 8-11.

UZIEL, A. P.; GROSSI, M.; MELLO, L. (orgs.) Conjugalidades, parentalidades e identidades lésbicas, gays e travestis. Rio de Janeiro: Garamond, 2006.

UZIEL, A. P.Homossexualidade e adoção. Rio de Janeiro: Garamond, 2007.

VANCE, C. Anthropology Rediscovers Sexuality: A Theoretical Comment. Social Science and Medicine 33 (8) 875-884, 1991. 
ZAMBRANO, E. Parentalidades “impensáveis": pais/mães homossexuais, travestis $e$ transexuais. Horizontes antropológicos. vol.12 no.26. Porto Alegre, July/Dec, 2006.

ZIMERMAN, D. E. Fundamentos psicanalíticos:teoria, técnica e clínica - uma abordagem didática. Porto Alegre: Artmed, 1999.

WEEKS, J. in LOURO, J. L. O corpo educado. Belo Horizonte: Editora Autêntica, 2001. 


\section{ANEXOS}

\section{1 - Questionário sócio-econômico}

1. Data: I_ I

2. Idade:

3. Estado civil atual:

4. Tem filhos?

5. (em caso de resposta afirmativa na questão anterior) Quantos? Qual é a idade e o sexo deles?
6. É religioso? ( ) Sim
( ) Não

7. (em caso de resposta afirmativa na questão anterior) Qual é a sua religião? Você freqüenta alguma instituição religiosa?

8. Assinale abaixo a alternativa que melhor representa o seu nível de escolaridade:

( ) sem escolaridade

( ) $1^{\circ}$. grau incompleto 
( ) $1^{\circ}$. grau completo

( ) $2^{\circ}$. grau incompleto

( ) $2^{\circ}$. grau completo

( ) superior incompleto

( ) superior completo

( ) pós-graduação incompleta

( ) pós-graduação completa

Observações:

9. Qual é a renda média mensal de sua família?

10. Como define sua cor: ( ) negro ( ) não negro

111. Você incluiu o seu parceiro no seu plano de previdência e seguro de vida?

( ) $\operatorname{sim}$ ( ) não 


\section{2 - Roteiro de entrevista semi-estruturada}

1 - Vamos falar um pouco sobre a sua história com seu parceiro. Comece por onde quiser, faça os destaques que quiser.

2- a) O que você diria ser o melhor dessa relação? Por que?

b) E o mais difícil? Por que?

c) Tem alguma situação que você poderia contar que melhor mostraria como é essa relação?

3 - Como era sua família de origem?

4- Há quanto tempo você está casado com esse parceiro?

5- Como foi a decisão de ficarem juntos?

6- Como os membros de sua família de origem se relacionam com o seu parceiro? Conte uma situação, a título de exemplo.

9- Você tem acompanhado o debate sobre a adoção por casais gays?

10- Há algum aspecto neste debate que mais lhe chama a atenção? Por que?

11- O que é família para você?

12 - Você teve critérios específicos quando resolveu adotar seu filho (a)? 


\title{
8.3 - Consentimento informado
}

\author{
Caro colaborador (a),
}

Sua participação é muito importante nesse estudo. Seja bem vindo (a). Neste projeto pretendemos entender melhor como se sentem e o que pensam os membros de famílias gays. Não existem em nosso país muitos estudos que nos orientem a respeito dessas famílias. Portanto, com a sua ajuda, estaremos participando de um esforço no sentido de gerar conhecimento científico sobre o assunto.

A participarão nesta pesquisa será, como você sabe, voluntária. Sinta-se livre para acolher ou rejeitar a proposta que este pesquisador lhe apresenta. Sabemos que algumas das perguntas que faremos referir-se-ão a assuntos íntimos e poderão causar vergonha ou embaraço. Não usaremos meias palavras durante as entrevistas. Buscar aprofundar o conhecimento de forma clara e direta será nosso propósito, sinta-se a vontade para não responder a qualquer pergunta.

As entrevistas terão duração média de uma hora (sessenta minutos). Lembre-se de que suas respostas serão estritamente confidenciais. Haverá somente um número de questionário como identificação de cada participante. Não haverá nenhum nome colado ao questionário e apenas eu (Luiz Celso Castro de Toledo), terei acesso direto aos mesmos. Como psicólogo e pesquisador a lei me permite guardar segredo sob requisição da justiça. Os dados obtidos com a sua colaboração serão usados apenas em porcentagens, números, comentários gerais e trechos de respostas dos entrevistados, sem nunca identificar quem fala, identificando-os com um nome fictício. O nome e a identidade dos entrevistados nunca serão mencionados nos resultados da pesquisa.

\footnotetext{
A sua sinceridade nas respostas será muito importante. A nós não interessará julgar nem dar quaisquer opiniões sobre o que as pessoas pensam e fazem ou deixam de fazer. Lembre-se: não se preocupe em dar a resposta socialmente correta, o que acha que seria bom responder ou deveria pensar. Responda o que acredita. Queremos conhecer o que você de fato sente e pensa!
}

Muito obrigado,

Luiz Celso Castro de Toledo

$E u$ concordo em me submeter a essa pesquisa de acordo com os propósitos e procedimentos anteriormente explicitados.

Obs: Para resolver dúvidas ou pedir esclarecimento adicionais, mesmo depois de terminada a entrevista, por favor procure a mim ou à ouvidora desta pesquisa (Professora Doutora Vera Sílvia Facciolla Paiva) na USP, (Universidade de São Paulo) no Departamento de Psicologia Social, telefone 3818-4361. Endereço: Avenida Professor Mello Moraes, 1721 - Caixa Postal 66.261 - CEP 05508900 - São Paulo - SP. 


\section{4 - ALEXANDRE}

Alexandre: entrevistado.

Nélson: companheiro de Alexandre.

Entrevistador: Pronto... vamos falar um pouco da sua história, sobre a sua história com seu parceiro, é... eu queria que você começasse contando por onde você quisesse, que você fizesse os destaques que você quisesse, o que você pode contar sobre essa história?

Alexandre: Bom, nós nos conhecemos, numa, numa balada assim... num dia que eu não achei que ia conhecer alguém, assim, tô numa fase bem desanimado de conhecer pessoas e não dá certo, né? Ele também, e aí a gente se conheceu e foi bacana, uma pessoa legal... e aí nós fomos ficando junto, nos apaixonamos, né? Tanto que a gente começou a dormir junto sempre, tal... e aí, assim, batiam as idéias, assim, os conceitos de vida. Tem coisas que nós somos muito diferentes, mas tem coisas que nós somos, assim, muito iguais também, como qualquer casal, né?

\section{Entrevistador: Hum.}

Alexandre: E aí a gente, depois de um tempo, depois de uns meses, a gente resolveu viver junto... só que eu vivia com minha mãe na época, né? Morava com ela. Minha relação com minha mãe é uma relação muito forte, né? Assim, é de muito apego, tal. E aí, eu tinha assumido o compromisso com minha mãe de ficar com ela, numa casa que a gente alugou, uma casa grande, tal. Tinha um compromisso financeiro muito grande com ela.

Entrevistador: Então você ajudava em casa?

Alexandre: Ajudava, é ajudava muito, sempre ajudei em casa né? Sempre ajudei ela, desde de... eu trabalho desde os 14 anos, sempre dei meu dinheiro pra ela... Aí o que aconteceu? Eu queria viver com ele, mas não podia deixar minha mãe. E a gente também... sem muitos recursos, assim, começo de vida. A gente decidiu que seria melhor, pelos menos por um tempo, ír mora com ela, né? Aí a gente pegou, foi pra lá, mudou pra lá, morar com a gente. E foi assim, uma fase muito boa, assim, foi muito bacana, a experiência, eu acho que, ele com a minha mãe, um relacionamento legal. E aí no meio disso aí, porque foi um ano assim, mui... de reviravolta pra mim, assim, foi uma fase foi uma fase doida.

\section{Entrevistador: Foi?}

Alexandre: É, nós tamos juntos já faz dois anos e, acho que dois, dois ou três meses, do dia que a gente se conheceu. E aí, como eu logo comecei a ficar com ele, tal, a gente foi morar junto, tal, logo me surgiu a oportunidade de trabalhar na $\mathrm{H}$, que era, uma coisa assim, que eu tava buscando sem sucesso já fazia anos, né? Sempre ia lá, fazia entrevista e não dava certo, já tinha desencanado, assim. Aí, quando eu desencanei, que eu tava trabalhando noutro lugar, já tava começando a montar um negócio pra mim aí deu certo lá, é.

Entrevistador: Acontece...

Alexandre: Quando eu tava assim, tipo, até ganhando bem no que eu tava fazendo, tava trabalhando num salão de beleza... aí fui contratado lá.

Entrevistador: Hum. 
Alexandre: Aí fui, né? Me adaptei totalmente. Novo salário, super pouco, perto do que eu tava ganhando, né? Mas, assim, tinha, eu tinha lá a oportunidade de estudar, que era o que, o que eu sempre quis, né? E aí fui. E, e, tudo mudou assim, meu ritmo mudou totalmente. Aí, a gente, já faz dois anos que eu tou lá, tou indo pro segundo ano de faculdade.

\section{Entrevistador: Hum.}

Alexandre: E... com o tempo, assim, acho que com todo esse processo que aconteceu comigo, eu comecei a ver que eu queria me desvincular da minha mãe, entendeu? Que eu queria ter uma vida com ele, que eu precisava do meu espaço. Do meu espaço com ele, mas do meu espaço, principalmente. Eu já tava com mais idade, tal. E aí comecei a ter uma crise aí, comecei a fazer terapia, tal, e com isso descobri que eu precisava me desvincular da minha mãe. E aí foi um processo, assim, consciente, eu comecei a, a gente começou a não se topar, né? Começou a não conseguir ocupar o mesmo espaço lá dentro. Né? E, de uma forma que eu vim, que a gente, veio pra cá, assim. Tava comprando uma casa, né?

\section{Entrevistador: Hum.}

Alexandre: Tá construindo lá, tá previsto pra entregar agora daqui uns meses, já faz um ano que a gente comprou. Só que aí eu precisava, não dava mais pra esperar sair a nossa casa, né? Precisava sair de casa. Aí foi onde eu consegui aqui, através do meu pai, consegui aqui pra gente ficar até ficar pronto lá e a gente sair de casa. Né? Mas, assim, ele sempre me dando muito apoio, né? Sempre me apoiando muito, ele me ajuda muito, meu ritmo é muito puxado, então, se não fosse ele, eu nem saía de casa, né? Porque, tem todas as coisas assim que a gente precisa de casa. Suporte, tal, cuidar da casa, enfim. E, é isso assim, a gente tem muitos sonhos juntos, né? A gente... pensa em adotar uma criança, né? Que era uma coisa que eu sempre quis, sempre, desde quando eu não tinha ninguém, há muitos anos eu sempre falei que queria adotar. Esses dias eu contei pra ele e ele falou que tinha, essa mesma vontade também, sabe? E aí a gente, conseguiu viver junto aí, fazer nossas conquistas juntos, tá dando certo, graças à Deus, tá dando certo.

Entrevistador: O que você diria que é o melhor dessa relação? E porquê.

Alexandre: Eu acho que é o nosso companheirismo assim, nós somos muito companheiros. A gente praticamente não briga, nós tivemos poucas discussões assim, sabe? A gente sempre se acerta depois. A gente não é de ficar brigando, aquele casal que sai, vai no supermercado e fica brigando. Fica discutindo. Sabe? O Nélson é muito tranqüilo, eu também... Eu sou uma pessoa mais estourada assim, sou oito ou oitenta, ou tou calmo ou tou muito estressado, ele já sabe meio me segurar, sabe? Ele me mostrou algumas coisas. E... tudo a dois é mais fácil. Você tem um suporte, você tem um suporte financeiro, você tem um suporte emocional. Pra tudo, entendeu? Acho que essa sensação é a melhor, assim, pro relacionamento é isso daí.

Entrevistador: Esse... quando você fala nesse suporte, né? Quando é que você sentiu que esse suporte, quando é que você sente que esse suporte é mais importante pra você, em que tipo de circunstância, de situação?

Alexandre: Ó, difícil dizer, porque ao mesmo tempo que eu gosto, eu tenho minha individualidade muito forte, né? Acho que é uma característica da minha personalidade mesmo, né? Individualidade, até às vezes, posso ser egoísta às vezes, né? Mas, é difícil de falar, acho que tem momentos que sente que precisa ter alguém do seu lado, é bom, né? Eu passo muito tempo fora de casa, eu passo a semana toda fora de casa, então eu tenho... outra vida assim, na faculdade, com meus amigos, é, coisas que ele não tem participação, né? Que ele é mais na dele. Mas, no momento que venho pra casa, ele tá aqui, né? Então, acho que é isso assim, na hora de, de recolher, de descansar, é melhor cê ter alguém mesmo, tá 
acompanhado, querer desabafar alguma coisa, conversar... Trocar uma idéia né? Pensar a dois. Com o tempo, assim, é muito legal, eu percebi que ele cresceu, porque eu tenho muita iniciativa, sou muito prático, gosto das coisas pra já, e ele não, com o tempo ele foi pegando um pouco disso, antes só eu falava, pra tomar uma decisão só eu falava, assim. Ele era mais pacato, tal, e agora eu percebo que ele me ajuda a pensar, sabe? E isso é muito legal. Ele...

Entrevistador: Quê tipo de decisão?

Alexandre: Ah, de todos os tipos... Profissional, familiar, pessoal, é... de relacionamento, sei lá, interpessoal, né? Eu percebo que ele, eu dava muita cabeçada. E eu acho que ele me ajuda a ficar um poço mais centrado. A ver algumas coisas que eu não enxergava... sozinho. Tem algumas coisas pra melhorar, como todo mundo, né? Mas tá, eu acho que, o que eu sinto que é mais gostoso, é isso daí, é essa troca, assim.

Entrevistador: E o que é o mais difícil na relação de vocês?

Alexandre: O que é o mais difícil?

Entrevistador: É, o quê é o difícil na relação de vocês, e porque?

Alexandre: Tá, eu vou falá pra mim, né? Eu não sei pra ele (fala rindo). Pra mim ao mesmo tempo que essa dependência é boa, né? É ruim. É ruim a... partir do momento que eu não controlei mais os... a dependência, né? Começa a me rasgar no sentido da minha individualidade e essa dependência, quando eu consigo manter harmonia entre essas duas coisas eu tô bem. Agora, quando eu preciso dele... Por exemplo, eu preciso da presença dele pra ficar bem, eu começo a sentir uma coisa assim... mais de insegurança. Eu não sei não demonstrar, eu demonstro. Acabo gerando situações que, às vezes nem tinham porque, não tinha necessidade... E... é isso assim, essa sensação de depender do outro ao mesmo tempo que é bom, ao mesmo tempo não é. Porque não se, eu queria ser assim, eu nunca tive uma individualidade, na minha vida, de sair de casa e fui morar sozinho. Eu não tive isso, eu já fui direto morando com alguém e construindo uma vida juntos, tal. $\mathrm{O}$ fato de eu ter saído e não tido, porque eu sempre quis sair, teve uma época que eu recebi proposta de trabalhar fora da cidade, né? Não sei se ia ser bom ou se não ia, mas eu tinha vontade de ir, e eu não pude ir por causa da minha mãe. Eu queria fazer intercâmbio, todos os meus amigos conseguiam, e minha mãe não deixava eu ir, né? Então, eu acho que vai ser uma frustração que eu sempre vou ter. Assim, de eu não ter tido minha fase minha. Sozinho, né? Mas nada que eu não consegui, assim, superar, que eu não consigo pensar que: não aconteceu, foi de outra maneira, né? Uma coisa que eu não tive, assim. Não é o fim do mundo. Não tive isso, tive vontade de ter, e não tive. Mas tou gostando, tou vivendo, e tá sendo super bacana.

Entrevistador: E me conta uma coisa, tem alguma situação específica, alguma situação de vivência concreta entre vocês, que possa contar sobre como é que é a relação de vocês?

Alexandre: Ah, eu acho que... de repente, uma situação que acontece bastante... que pode de repente desenhar aí bacana como é que é a troca entre eu e ele, às vezes eu tou lá muito encanado com alguma coisa... um... ou que eu acho, ou que eu quero saber, ou que eu quero conversar, discutir a relação. Ou com algum problema, tal, às vezes aí a gente vai deitar, vai dormir e aí eu sento, tiro minha botina, aí eu, a gente começa a conversar e eu disparo a falar, falo, falo, falo, falo, falo, falo, falo (risos), falo, argumento, penso, repenso... e ele fica ouvindo. E aí, quando eu termino, quando eu tou mais calmo: você já terminou? (risos) Ah, eu terminei. Tá mais calmo? Tô. Tá, então amanhã a gente conversa, ele fala. E ele deita e dorme (risos), né? E eu fico indignado, como ele consegue deitar e dormir, eu num, eu ainda fico ali pensando um pouco, mesmo estando um pouco mais calmo, tal, eu ainda demoro a dormir pra desligar. Acho que é isso, assim, sabe? E depois amanhã a gente realmente volta a 
conversar, no momento que ele quer, que ele acha... mais conveniente. Às vezes eu nem estou mais tão preocupado. E a gente acaba se entendendo melhor. Mas isso daí é... eu acho que foi da vida que eu tive mesmo, desde pequeno eu sempre tive que ser muito responsável, né? Minha mãe não teve um bom relacionamento com meu pai e eu sou o filho mais velho. A minha irmã sempre teve muito problema de saúde, graças à Deus hoje ela tá bem. Mas ela... assim, quase morreu muitas vezes por causa de falta de ar, né? Ao ponto da gente tá a caminho do hospital e não saber se ia chegar.

Entrevistador: O que ela tinha?

Alexandre: Asma. Hoje ela não tem mais, só de vez em quando dá uma, eu tive também, mas o meu foi bem mais fraco que o dela e garoto eu não tive mais. A minha irmã foi mais, foi mais sério. E, eu acho, o meu pai traía muito minha mãe, né? E sempre teve outros relacionamentos, minha mãe sofria muito com isso. Meu pai saiu de casa várias vezes, eu via isso, né? E eu comecei a trabalhar muito cedo porque o relacionamento da minha mãe com ele não deu muito certo. Então acho que essa responsabilidade é forte em mim, né? Eu me cobro muito. Antes disso, antes deu começar a trabalhar eu já cuidava da minha irmã, desde que ela é pequenininha, eu ainda era um pouco maior, eu cuidava dela, a minha mãe trabalhava. Eu ficava lá o dia inteiro em casa, ela, os dois estudavam, mas meio período a gente ficava em casa, eu ficava cuidando dela. Então acho que eu fiquei muito responsável, né? E talvez tenha chegado uma época que eu não queria ser tanto, né? $\mathrm{E}$ eu acho que isso daí desenvolveu isso em mim assim, às vezes eu não consigo controlar essa coisa de... de querer tá controlando mesmo a situação, de querer que esteja tudo sob controle. De querer resolver, né? É difícil pra mim, assim, ter uma situação que eu não controlo, né? Graças à Deus, hoje, assim, não tem nenhuma (risos), hoje tá tudo sob controle, né? A gente precisa, assim, se a gente vai fazer uma dívida, levantar financiamento, precisa tá com aquilo desenhado, exatamente como é que vai sê... dali até quando terminar. Tudo assim, assim, bem sistemático, é por aí.

Entrevistador: E você começou a contar como é que era tua família de origem... Eu queria que você contasse mais, o que você pode contar sobre sua família de origem?

Alexandre: Então, é... eu tive uma infância bacana, né? Eu não contei pra minha mãe que eu era gay. Só contei, fui contar pra ela mais velho, quando eu tive um... um relacionamento, eu precisei contar, porque a situação precisou que eu falasse pra ela, que ela não tava entendendo o que tava acontecendo. Uma coisa, assim, meu pai sempre foi muito amoroso comigo, né? Ele sempre me deu muito carinho, nunca me deu um tapa, acho que uma vez só, sempre foi muito compreensivo, tal. Sempre falava umas coisas meio filosofia pra gente... A lei! (mostra a mão como se estivesse segurando um sapato), a lei aqui, ó! Vai deitar! E... só que meu pai não era responsável, né? Ele tinha esses outros relacionamentos, eu cheguei a ver alguns... mas quando eu era pequeno ele me levava na casa, na casa da das amantes dele como se fosse amiga. Eu entendia como criança, né? Entendia mas não percebia. Quer dizer, sei lá, como é esse processo aí, quando a gente tá vivendo é difícil de explicar. A minha mãe sempre foi muito mais parecida comigo, assim, esse jeito da minha mãe, esse jeito de, de ser, só que minha mãe tem os extremos muito mais elevados que o meu, né? Esse negócio de ser controlador, agitado, é, eu tenho muito da personalidade da minha mãe, aliás, quando a gente não começou a não dar certo, eu acho que foi por causa disso. Né? É, por exemplo, se eu tenho um ponto de vista...

Entrevistador: Quando você fala que "a gente começou a não dar certo", você tá se referindo à sua relação com ela?

Alexandre: É. Se eu tenho um ponto de vista e ela também tem, é difícil a gente entrar num consenso, entendeu? Porque eu sou muito determinado e ela também. Né? E se eu quero co... 
administrar a coisa de uma maneira, ela tem outra maneira, eu não aceito a maneira dela e ela não aceita a minha, né? E é difícil assim, né? Porque eu tava na casa dela. E, e só que minha mãe, assim, sempre me passou assim muita responsabilidade, acho que foi minha mãe que me educou assim, que falava as coisas né? Assim, meu pai sempre foi mais... calmo, mais... tranqüilo. É... aí veio minha irmã, meu rela... meu relacionamento com minha irmã é bem bacana, assim... a gente teve, tive uma infância legal, meu pai tinha um bom emprego, minha mãe também trabalhava, tinha um bom emprego. E aí, depois, aí a gente teve uma crise, assim, financeira bem difícil, até que, eu acho que foi naquela época que o Brasil entrou naquela crise, tal, e a gente, assim, ficou financeiramente muito, muito pobre mesmo, né? Minha mãe tava construindo uma casa lá, onde a gente, numa construção no fundo, numa casa de esquina e parou no meio. Não deu pra terminar, teve uns desvios lá de.. de dinheiro. E aí meu pai não arrumava emprego, não arrumava emprego, e a situação ficou mui... ficou muito delicada. Ficou com condições muito precárias de... de vida mesmo, pra poder manter alguma coisa, né? A gente acabou indo morar naquela construção, pra deixar aquela casa que tava pronta pra alugar, pra ter algum subsídio, tal. Isso tudo minha mãe, né? E aí meu pai saiu de casa, já tinha saído várias vezes, mas teve a última vez, fui eu que pedi pra ele sair. Minha mãe tava muito mal, assim, tava com uma depressão muito grave, tava bebendo e tal. Aí eu falei pro meu pai sair e ele saiu e não voltou mais. E aí eu comecei a trabalhar... E, aos pouquinhos, bem aos pouquinhos mesmo a gente foi se se reestruturando, né? Eu... tenho uma personalidade simples, assim, eu gosto de... conforto material, tal, mas, eu não tenho tantas, é... vontade de ter muita coisa, assim, quero ter minhas coisinhas. Minha casinha ajeitada, do jeitinho que eu quero, tudo bonitinho. Mas não penso mais em ter aquela mansão. Ter uma vida, assim, sabe? É... sei lá.

Entrevistador: Você comentou de quando contou pra ela que era gay. Como é que foi?

Alexandre: Ah, foi muito difícil... foi muito difícil. É, comecei a namorar um rapaz, e comecei a ficar fora de casa todo dia, às vezes dormia fora, chegava tarde. Minha mãe não entendia o que tava acontecendo, achava que eu tava namorando uma menina e... e o fato de eu já tá dormindo na casa dele logo no começo, sem apresentar pra ela, deixou ela... Minha mãe é muito encanada com esse negócio de: ah!, porque é biscate. Sabe? Ah! Porque é vulgar. Ela é meio... é... acho que até ela é meio quadrada demais, largou do meu pai, nunca... arrumou outro namorado firme... porque acha que... tem que manter a... tem filhos, uma mulher com filhos, sabe assim? Podia ter um pouco de vulgaridade, um pouco de sensualidade, ela não tem. Então tudo o que é relacionado à sensualidade, deixa ela muito... sabe? Não fica nada a vontade, ela não fica. A minha irmã sempre viveu brigando, sempre, não deixando ela sair com roupa mostrando um pouquinho mais a barriga. É uma morte pra ela. E acho que o fato dela achar que eu tava namorando uma menina, que já tava transando, já tava dormindo com ela e nem tinha apresentado pra ela, no pensamento dela era um absurdo. E eu não contava pra ela o que tava acontecendo, né? Não podia contar. E ela começou a achar que era uma coisa errada, ou que sei lá, que eu tava envolvido com drogas, sei lá o que ela achava... E a gente teve um fecha assim, feio mesmo, foi uma discussão muito feia, ela falou que era pra eu sair de casa se eu, se eu tivesse fazendo alguma coisa errada, que ela não ia me aceitar. Aí, senti necessi... senti que eu t... senti que tinha que contar, né? Senti que tinha chegado o momento extremo. Que várias, dessas encanações, assim, né? Acho que extremas com a minha mãe, assim de, minha mãe faz um pouco, ela potencializa um pouco as coisas, entendeu? Não precisava ser tão sofrida as coisas como foram, na vida dela até, né? Acho que ela potencializa, mas ela tem depressão tal, agora que ela fez tratamento tá melhorando. E aí fui contei, assim. Peguei ela no trabalho, levei ela pra uma pracinha, que eu não queria contar em casa... prá não ficar aquela coisa mãe e filho né? (risos). Levei ela pra uma pracinha lá perto do trabalho dela e falei pra ela, contei pra ela. Fui dando a entender, dando a entender, jogando indireta, né? Ela f... ela falou, não lembro como foi a conversa, ela falou: porque? Que ela já conhecia o menino, ela falou: porque, vocês estão namorando? Eu fui dando indireta pra ela perguntar, aí eu falei: E se for? Ah, eu vou te 
amar do mesmo jeito. Aí foi aquela choradeira, né? Aí, tal, só que eu tive que explicar tudo pra minha mãe, sabe? Assim, desde o que é ativo, o que é passivo, ela achava assim, que, tinha diferença de bicha, gay, é... viado. Esses, esses termos que ela ouvia, né? Como que era isso, o que acontecia, aí aquele medo de mãe de, de que alguém ia me, destruir, porque eu era gay. Aí comecei a explicar, explicar... Eu não tenho muita paciência com minha mãe. Não sei porquê. Eu tenho paciência com ela, assim, até um ponto, mas eu tenho é... passou dali não tenho mais. E é difícil pra mim sentar e explicar uma coisa detalhada pra minha mãe, não sei porque (risos). Sabe? O Nélson tem muita paciência com ela ... é, apesar que é dif... minha mãe é uma pessoa difícil, mas eu não tenho. Mas tudo bem, consegui viver esse processo, expliquei pra ela, comecei a falar dos meus amigos que, se eram amigos, assim, de muitos anos, que ela conhecia e que não tinham estereótipo nenhum. Sabe? Oh, fulano é, fulano é. Pessoas que tinham referência assim, né? E aí ela começou a entender isso daí. E aí contei pro meu irmão, mas demorou. Eu percebi que demorou muito pra ela aceitar. Ela compreendeu, ela aceitou pra todo mundo, ela aceitou, ela me defendia mas eu percebi que, dentro dela, ela ainda tinha assim co... mesmo que passou um ano, assim, ela ainda tinha uma coisa assim, que eu ainda ia conhecer uma menina. E aquilo ia acabar. Aí eu fui trabalhar no mesmo salão que ela, né? Eu acho que aquilo, ao mesmo tempo que foi bom pra nós, é... por essa questão da sensualidade que ela não trabalha bem, eu sou uma personalidade ... assim sensu... sensualizada, assim, vamos dizer assim, né? É... sexualizada pelas pessoas. As pessoas olham pra mim: ah, ele é gay, né? Ainda mais no salão, assim, que eu, que eu tava... tava sempre assim, chhhiiii, assim, de cabelo arrumado, sabe? Cliente... Você precisa tá legal... Eu não escondo. Não saio falando, mas não escondo... E aquilo, não sei como é que foi aquilo pra ela, né? Ela me defendia bem mas acho que, dentro dela, não sei se até que ponto, acho que foi bom pra ela vencer um pouco essas, essas besteiras. Mas agora, assim, hoje em dia depois que eu conheci ele, no que ela viu que, que tava sério, ela aprendeu. Hoje é normal. Ela me aceita, normal. Mas eu ter saído de casa fez muito bem pra nós dois, assim... pra ela também fez bem. Ela tá se cuidando. Ela já tá deixando os remédios dela sem o psiquiatra saber, porque o psiquiatra falou que agora ela vai tomar muito tempo e eu expliquei pra ela, né? Os efeitos, tal, que talvez ela não consiga mais parar, então ela mesmo falou: não, eu vou parar, eu vou tirar isso de mim, não vou ter mais depressão, tá fazendo natação, emagreceu. Tudo depois de eu saí de casa, né? Então eu não, não sei porque ela não fez isso antes. Pra mim achei que não ia me adaptar nunca. Sem minha mãe, sem a estrutura lá de casa. Mas, me adaptei, assim. Aliás, me adapto muito bem a qualquer situação. Ele tá trabalhando, tem dia que ele trabalha de madrugada, tem dia que ele trabalha de dia... muda de emprego, me adaptei aos horários dele e aprendi a adaptar isso com meus horários, que já são tumultuados, assim, e sou muito flexível, né? E acho que foi isso assim.

Entrevistador: E me conta o seguinte, vocês tão casados há, dois anos e meio?

Alexandre: Não, desde o dia que nós nos conhecemos... Então, é, dali a uns 4 meses ele mudou pra casa da minha mãe, mas desde de muito, assim, no início, acho que de... depois do primeiro mês, a gente sempre dormiu juntos, eu dormia na casa dele. Ele morava com uns amigos. Acho que na... ... Ah, sei lá! Foi logo no começo, a gente começou a dormir junto e logo a gente tava dormindo todo dia. Então eu considero que não houve um namoro (risos).

Entrevistador: (risos) Foi direto.

Alexandre: Foi direto, né? Mas faz uns dois anos e dois meses aí.

Entrevistador: E como é que foi essa decisão de vocês ficarem juntos, como vocês resolveram isso?

Alexandre: Ah, não foi muito pensado, assim, foi pensado, mas foi bastante no... na impulsividade, né? Acho que a vontade de querer ter alguém sempre foi muito forte, enfim... 
Resolvemos e foi sentimento, né? Aquela coisa, assim, de amor mesmo. E a vontade de ficar junto e boa. Eu sou assim, né? Sou muito de fazer logo. E ver as consequiências depois. Quero me arrepender só das coisas que não eu fiz na vida. Então foi, logo ele tava lá e foi dando certo porque eu acho que as personalidades se encaixaram, né? É, no fundo, é lógico, conheci ele, vi que ele era a pessoa que queria, tive outras pessoas que não aconteceu isso, acho que tudo encaixou ali. Eu lembro que logo no começo do, da minha relação com ele, eu falei pra minha mãe: mãe, se ele for isso tudo que eu tou vendo que ele é, eu não vou perder, porque eu nunca conheci alguém assim e olha que eu conheci muita gente, que sempre fui vassourinha (risos), sabe? Sempre saía e... conheci um monte de gente, ficava mesmo, sabe? Se queria beijar o cara, beijava mesmo e nem perguntava o nome. E ia embora pra minha casa. Nunca tive pudor nenhum, assim. Pra essas coisas de: ah, vou ficar, não vou ficar, porque, sei lá, vou pegar bichinho. De, de, sabe, vai me dar sapinho. E... quer dizer, de, de todo mundo que eu conhecia e acabei fazendo um, uma amizade muito grande com essas pessoas que conhecia, a gente ficava e depois ficava amigo, assim, amizade geralmente, muito forte, muito sincera... Mas ninguém era igual ele, assim, não, não teve o encaixe. De... força de vontade, de personalidade. Então eu resolvi lutar por isso, né? E tô lutando, a gente tá lutando junto e... por mim tá dando certo assim.

Entrevistador: Então você me diria que foi uma mais decisão impulsiva do que uma decisão planejada?

Alexandre: Foi uma decisão impulsiva. Lógico que a gente planejava, mas já junto, né? Nós... eu falei já, sempre insisti com ele que a gente ia conseguir comprar uma casa, em vez de alugar uma casa, foi por isso que a gente foi pra minha mãe, pra ter condições pra isso, mas assim, já junto, começando a planejar nossa vida à dois, né? Não foi assim. Ah, ele morava na casa dele, eu na minha, a gente foi planejando, começando a juntar dinheiro... não! (risos)

Entrevistador: Já estava acontecendo.

Alexandre: É, e começamos nossa vida aí, do zero, né? Estamos no início ainda, temos muita coisa pra ser conquistada, né? Mas estamos no caminho.

Entrevistador: E, bom, a próxima você também já me respondeu um pouco, mas talvez você possa me contar mais à respeito. A pergunta é: como é que os membros da sua família de origem se relacionam com seu parceiro?

Alexandre: Bem, assim, pra você entender de como me aceitaram, né? Foi super tranquilo, né? Foi super de boa. A minha mãe saiu contando pra família inteira, no sentido assim, de: meu filho é gay e se alguém falar alguma coisa, vai se ver comigo, não quero ninguém destratando e tal. E foi bacana que, as minhas tias me ligavam, pra me falar que minha mãe tinha comentado que me amavam do mesmo jeito, todo mundo me falou isso, sabe? Ah, eu te amo, você continua sendo a mesma pessoa pra mim. Aí quando ela contou pro meu pai, meu pai na época, eu num... num tinha o vínculo que eu tenho com ele hoje, eu tenho um vínculo maior com ele, talvez seja até isso que nos aproximou. Ele me ligou e falou: ah, é, eu ...entendo, eu te... gosto de você. $\mathrm{E}$ ainda ele falou: não, não acho que... não precisava se afastar do jeito que se afastou, né? Foi, assim, que eu pequei o papel dele em casa, não tinha mais tempo pro meu pai mais, né? E eu era adolescente, jovem, eu queria ter meu final de semana saindo por aí. Mas hoje a gente se uniu muito e meu pai teve um bebê com a mulher dele, né? E quando meu irmão nasceu... eu vou lá toda semana, né? Então a gente tá muito mais próximo. Então me aceitaram, gente que eu achei que nem, nunca imaginei que eles poderiam ter um fato desse na família e aceitaram tão, tão de boa, assim, naturalmente, meus priminhos, assim, tenho um afilhado que tem um priminho meu, que é meu afilhado... eles sabem, foi natural. As minhas tias, assim, receberam ele de braços abertos. Mas não tenho 
muito contato, não tenho, não vejo minha família, né? Pra não dar tempo de dá algum problema. A família da minha mãe é a que eu tenho mais contato, a família do meu pai eu não tenho contato... A família da minha mãe, eles nunca se deram bem, eles brigaram muito, né? Quando eles moravam todo mundo na mesma casa era uma loucura, parecia um ringue, né?

\section{Entrevistador: Como era?}

Alexandre: Brigava mesmo, de se pegar. Então acho que conforme foi cada um pra um canto, não se reúnem muito, assim, passam semanas, às vezes passo meses sem ver alguém. Mas na, assim, na hora da dificuldade é uma coisa muito unida. A gente perdeu uma tia minha faz uns três anos, morreu uma irmã da minha mãe e foi uma coisa muito legal essa união da família naquele momento. Mas só naquele momento, não tem mais momento nenhum que tem aquela união, né? E todos eles me aceitaram, meus primos, eu tenho um primo que é maior e hoje ele chega e me dá um beijo no rosto... ele é hetero, né? Mas ele chega e me dá um beijo no rosto quando ele me vê. E eu fico... fico, sabe, assim mas num constrangimento porque, eles me aceitaram muito, né? E a mesma coisa foi com ele, assim, quando alguém vê, quando alguém encontra, trata normal. É, então assim, né? O meu tio, tenho um tio, irmão da minha mãe, que ele é totalmente, fechado, né? Ele é muito, até depois que a irmã dele morreu, ele ficou mais aberto, com mais vontade de fazer as coisas por nós. Porque ele se arrependeu muito de não ter feito nada pela irmã dele e a irmã dele morreu... e ele é muito fechado, muita dificuldade. E ele brinca muito comigo, às vezes eu ligo, às vezes ele me liga: vem almoçar aqui, traz seu maridinho, ele fala. Traz, traz aí seu, seu menino, ele fica fazendo essas brincadeiras. A gente vai lá, ele fica, ... às vezes assim... é, às vezes eu falo: pega alguma coisa lá pra mim. Ele fala assim: tou vendo quem é que manda lá. Sabe essas brincadeiras assim? Dando a entender totalmente, abertamente que... que aceita, né? Então, normal. Não sei se sentiu tão bem recebido, mas eu vejo que ninguém... falou nada, né? Meu vô uma vez falou... falou pra minha mãe, mas minha mãe já... deu três medida nele. (risos)

\section{Entrevistador: E encerrou o assunto?}

Alexandre: É, encerrou o assunto. Assim.

Entrevistador: E me conta o seguinte, você tem acompanhado o debate sobre a adoção por casal gays?

Alexandre: Hoje nem tanto, mas eu tenho acompanhado sim. Conheci o... os meninos lá de Catanduva, quando eles vieram aqui na cidade pro encontro na faculdade, né? Fui lá ver. Sempre que sai alguma coisa, assim, procuro ficar interado. Aliás, na época que eu tava militando, a gente teve o primeiro caso de união estável registrado em cartório. Foram dois amigos meus, eu que consegui, né?

\section{Entrevistador: É?}

Alexandre: Eu era bem assim, atuante. Sei que tá mais fácil hoje em dia, aqui tem o juiz da vara da infância e da juventude... ele é bem aberto, ele não é um juiz preconceituoso, né? E... conheço as psicólogas que trabalham lá, a Cibele e a outra lá, que eu esqueci o nome agora, e elas são muito assim, abertas né? Não tem uma lei específica ainda. Mas já é possível, assim... Já... já... dependendo de... do juiz que você pegar, né? Aqui mesmo já é possível, porque já teve um caso, né? Se já teve um caso, daqui a um tempo tem mais, né? À partir do momento que teve um, abre uma, abriu um caminho, mesmo que não tem na lei. $\mathrm{E}$ infelizmente tem que ser assim, não tem outro caminho. Acho que não precisava ter tudo isso se fosse uma sociedade, assim, que aceitasse, mas a gente tem que lutar, né? Não tem o 
direito, tem que lutar. E eu acho que, de uns tempos pra cá a coisa tá fluindo... tem muitas dificuldades, ainda tem, mas tá fluindo muito bem. Depois daquele ano que teve aquele Jean, no Big Brother, né? Acho que ele foi uma personalidade muito importante na sociedade do Brasil pra... pro povo ter uma referência de um gay que é inteligente, centrado é... sabe? Com um pouco assim de moral, deixar um pouco aquela imagem de... de promiscuidade de lado, né? Que não sejam promíscuos, a grande maioria é... Mas acho que isso é uma conseqüência da... da marginalização mesmo, né? Que ocorre. É... mas acho que tá mudando sim, eu vejo com bons olhos assim... da maneira que tá acontecendo, se tem que ser assim, acho que... de uns tempos pra cá não tem tanta violência, não tinha, não fico sabendo tanto, igual tinha antes. Igual tinha antes casos de morte assim, né? De perseguição e tal. Tem, mas hoje é a partir da postura que a pessoa se coloca... não estou julgando, mas, assim, se você tem... seja um gay, seja um negro, ou seja, sei lá, um baixinho, um gordinho, alguém que tem alguma diferença, qualquer um desses diferentes do... padrão, se comportar de uma maneira... se permitir se colocar na... mas eu acho que já tem quem consegue superar isso e ter uma postura de... de querer ter seu espaço. De... não ter medo, acho que já consegue não sofrer esse tanto. Eu acho que já consegue impor o seu respeito. Nem que tiver que impor mesmo. Eu acho que já dá pra fazer isso... porque antes não, você não conseguia, né? Por mais que você gritasse, você ia levar pedrada mesmo e... acho que já dá. É por aí.

Entrevistador: E me conta o seguinte, o que é família pra você, Alexandre?

Alexandre: Ah, eu acho que a família é uma, uma base, né? Pra ficar com definições, assim, que já existem (risos), vou fazer pra mim: o que é...? Sei lá, acho que é de onde a gente vem, né? A formação mesmo de tudo tá inserida ali na família, não tem outro jeito. Hoje já, quando eu penso em família, eu já não consigo pensar tanto... na família que eu tive, na família da minha formação, mas na família que eu quero construir.

\section{Entrevistador: E como é isso?}

Alexandre: Aí... um, eu quero construir uma família, assim, super bonita, super normal, né? E... é um desafio pra mim, né...? Acho que, construir uma família assim. A gente quer ter uma menina, né? Eu falo em ter outro... Mas eu não sei como é que vai ser, nunca tive controle, eu vivi na família da minha mãe, do meu pai lá, tal, mas agora vou construir minha família. Eu chamo de desafio, assim, é... tentar não... não fazer, por exemplo, minha filha, nossa filha, né? Sofrer com isso. Tentar dar suporte pra ela conviver com isso e tentar fazer com que ela conviva com isso e supere isso na nossa cidade mesmo. Eu não sei o que vai acontecer, como vai ser a personalidade da criança, né? Eu tenho muita curiosidade e muita vontade de vivenciar isso mesmo, né? De conseguir educar, de consegui ensinar, né? Daquela coisa de ter um filho, né? E, mas assim, não tá na hora ainda... Acho que a gente só não pegou ainda, só não fomos atrás porque nós não estamos no nosso momento, se dependesse da vontade, da impulsividade (risos), iria, mas acho que a impulsividade já... já passou a época, agora a gente tem que pensar, né? Mas acho que é nesse sentido, assim.

Entrevistador: E, bom, essa você também já começou a responder. Você falou que quer adotar uma menina, minha pergunta é: você teria critérios específicos pra adotar uma criança?

Alexandre: Nós temos assim, né? A gente só pensa em um critério, a gente quer uma menina negra. E o fato, assim, de ela... da gente querer uma menina negra, eu não sei te explicar porquê que é... mas a gente visualiza uma criança negra. A gente não quer uma criança branca. Até tem uma bonequinha ali que eu dei pra ele, eu dei uma boneca de pano pra ele quando a gente fez um ano de... de.. de... de relacionamento. Uma bonequinha preta. E quando eu fui pedir pra menina que trabalha comigo pra fazer a boneca, ela só queria fazer branquinha, branquinha, branquinha, branquinha (risos). Eu falei: você faz uma preta pra 
mim?. Ai, mas uma boneca uma preta? Sabe aquela coisa? Então, eu não se é vontade de... de... de querer ter alguém, num sei, que tenha alguma diferença, mesmo que vá sofrer... ou não sei se é uma identificação... Com o preconceito racial, de ajudar alguém a superar, não sei te explicar o que é, se é gosto mesmo...Se é consciência de que lá as crianças negras não conseguem oportunidade. É, acho que é tudo. É tudo um pouco. Antes a gente queria recém nascido, agora a gente já tá mudando de idéia. Pegar um pouquinho mais crescidinho pra num... assim, pela dificuldade que eles tem de ser adotados depois de um tempo e pelo trabalho que dá. Já que Deus me deu a oportunidade de ser gay, acho que eu não preciso encarar aquela fase de recém nascido (risos).

Entrevistador: (risos) Tá bom. E, bom, acho que o básico do que eu queria perguntar já perguntei. Tem mais alguma coisa que eu não perguntei e que você gostaria de acrescentar na sua entrevista?

Alexandre: É, eu... eu acho, assim, que é... eu acho assim que... de acordo com aquela postura que eu falei agora pouco, eu não tenho dificuldade em ser gay, eu já tive, é, quando eu queria me auto afirmar perante às pessoas, mas eu não tenho mais essa necessidade. Hoje eu sou o que sou e eu sou agradável, não porque eu sou gay ou porque eu sou hetero. Eu sou agradável porque eu tenho outras coisas na minha personalidade que me faz ter amigos, que me faz me dá bem com as pessoas, que me faz ser aceito. E essas outras características que eu tenho fazem com que as outras pessoas aceitem a minha orientação sexual melhor. A única coisa que me preocupa é que elas vejam primeiro a minha personalidade e com ela o meu mundo... gay, né? Eu tive muita sorte, tá? Com relação, assim, a política, a... por exemplo, quando a gente foi comprar nossa casa eu... foi, aí cheguei no banco, tal, tinha que incluí o nome lá no financiamento. Só que não tinha tido essa situação, eu acho que nosso caso foi o primeiro que teve. Se não foi um dos primeiros. E eu coloquei o nome dele e quando a gente chegou lá, eu sentei com o gerente e ele questionou qual era a nossa ligação, né? E aí eu fui com uma historinha de que nós éramos sócios, que a gente queria é... construir uma coisa, assim, tal, uma casa como estabelecimento, nós éramos sócios, mas o gerente percebeu... lógico, né? Eu também não sou assim o exemplo de masculinidade, né (risos)? E ele percebeu, só que ele foi muito bacana, então acho que eu tive sorte com... nas situações que eu precisei, né? Ele... ele perguntou. Ele falou assim: olha, vou te fazer uma pergunta, vocês tem relacionamento estável, relacionamento afetivo estável?... Eu fiquei assim, né? Falei: não preciso de responder isso. Falei pra ele. Ele falou: precisa sim, quem vai aprovar sua renda sou eu. E eu não vou aprovar sua renda se você... pelo que você é, eu quero saber se você tem dinheiro pra pagar, só que eu quero a verdade... Vocês tem dinheiro, né? Ele falou. Aí ele falou pra mim: e pra mim é mais fácil conseguir liberar esse financiamento se vocês forem um casal do que se vocês forem sócios, porque como sócios vocês não tem vínculo nenhum. E eu fiquei assim, né? Totalmente sem reação. Porque já ti... já tinha tido o caso do outro banco, que eu fiquei sabendo no movimento, que, negou e entraram com um processo... e eu não queira passar por aquilo. E eu falei pra ele, assim, né? Totalmente sem com... sem controle da situação, coisa que eu não gosto (risos), já falei. Falei, e ele falou: olha, é assim... me explicou e depois ele falou: eu acho um absurdo pessoas como vocês terem que passar por isso e eu não vou barrar vocês por causa disso, eu vou cuidar disso pessoalmente. Quer dizer, não é todo homossexual que consegue isso, né? Encontrar uma pessoa assim. Se fosse alguma pessoa preconceituosa, eu não conseguiria. É igual uma ordem judicial ou processo. Se você pegar um juiz bacana, você vai conseguir o que você quer, se o cara for preconceituoso, você não vai conseguir. Entendeu? Então, eu acho que o momento histórico depende disso daí, um pouco, né? De você conseguir, assim, as pessoas certas no seu caminho, de repente você tem o merecimento daquilo, ou não tá no momento de você conseguir, também não sei bem como é que isso funciona, né? Mas eu acho que não tem muito controle, acho que a parte política, parte de legislação dá pra dar as voltas, entendeu? Lá nos artigos e nos parágrafos... Eu acho que tem como... fazer a coisa acontecer mesmo sendo explícito, né? Mas depende muito... é isso daí. 


\section{5 - MARCOS}

Marcos: entrevistado.

Paulo: companheiro de Marcos.

Entrevistador: Então vamos falar um pouco da sua história com o teu parceiro... queria que você contasse a história de vocês dois do jeito que você quiser, fazendo os destaques que você quiser.

Marcos: É... eu acho assim... o mundo homossexual... o casal homossexual... eu acho que... principalmente homens é muito mais complexo...muito mais complicado você acreditar em fidelidade...eu tive algum... algumas experiências assim de ficar com algumas pessoas antes do Paulo... na verdade eu tive um relacionamento de sete meses com uma pessoa extremamente complicada que me fez amadurecer muito... com relação a isso e eu nunca fui uma pessoa de ter muitos relacionamentos... eu sempre fui... mesmo quando tinha relacionamento com mulheres antes de definir minha sexualidade... eu nunca fui de ficar tendo várias namoradas... geralmente pessoas muito fixas dentro da minha vida.... eu percebi que no... no âmbito homossexual isso é mais complicado... as pessoas traem muito mais facilmente... e aí... pra mim isso era muito complicado admitir esse tipo de situação... porque eu não acreditava que as pessoas tivessem tal facilidade pra tal coisa... quando... conheci o Paulo...na verdade... realmente... o que me chamou a atenção em... em procurá-lo depois... até mesmo porque naquele dia a gente nem se conheceu... a gente se falou um oi... foi...foi apresentado um pro outro...foi a atitude dele... porque eu acho que realmente ele tinha gostado mesmo de mim...porque eu estava ficando com uma outra pessoa... e mesmo assim ele quis me conhecer até depois... ele deixou com uma amiga minha que tava na boate nesse dia... que na verdade foi o primeiro dia que eu tinha ido na boate na minha vida... uma boate homossexual... e... ele deixou o telefone... e todos os telefones possíveis... até do trabalho dele... que era mais difícil de falar... é... pra que eu entrasse em contato de qualquer jeito... email... telefones... até telefones dos amigos que moravam com ele... eu falei... é... realmente deve ter um interesse muito grande em me conhecer... né? Eu até voltei pra casa no sábado de madrugada... passou o domingo... eu falei... ah, eu não vou ligar não...acho que... sei lá... acho que não tem nada a haver... depois passou um tempo, quando foi na segunda à tarde eu resolvi ligar depois que eu cheguei do trabalho... e foi aí que tudo começou ... né...mas a... o que mais me chamou a atenção foi essa atitude dele... porque eu acho que nesse meio é muito difícil as pessoas terem esse tipo de atitude ... as pessoas chegam... querem te conhecer... se você tá com outro é problema seu... no dia que a gente se encontrar a gente conversa de novo... é bem mais ou menos assim, pelo menos assim... o que a gente presencia é mais isso. E conhcer pessoas que realmente estão dispostas a conhecer mesmo... é claro que depois você vai ver as intenções muito mais depois... mas o que mais chamou a atenção foi isso... é uma relação que tem seus desgastes... é... eu acho que como qualquer relacionamento... principalmente quando ele cai em uma rotina... então é uma coisa que você tem que mudar sempre.. que você tem que tá fazendo algumas coisas diferentes pra que as coisas mudem e você não se estresse no dia a dia... e que você não passe a desrespeitar e você tenha as suas fraquezas e você tem que controlar tudo isso, você tem que cada dia conquistar de um jeito diferente e você tem seus desgastes, você briga muito... como eu acho que em qualquer relacionamento, é muito difícil você não ter discussões... Isso acontece...mas, assim, no todo é um relacionamento muito bom... Pelo menos é minha opinião.

Entrevistador: E se você fosse fazer destaques sobre o que você acha que é o melhor da relação, o que você destacaria?

Marcos: Eu acho que é o companheirismo mesmo...como o Paulo mesmo diz... é... eu acho assim... eu ajudo... eu pelo menos acho que eu ajudo e ele sempre me ajuda. Eu acho que, 
assim, ele sempre tá mais disposto em fazer algumas coisas às vezes até do que eu... é... eu não sei se é porque ele... ele tem uma rotina de trabalho mais desgas... não uma rotina de trabalho mais desgastante... mas eu acho assim... a rotina do dia dele é mais desgastante porque ele tem que acordar muito mais cedo do que eu. Viajar. Eu também viajo todos os dias porque estudo fora... mas ele viaja... Ele sai do trabalho, ele tem que ficar esperando pra gente ter um...um custo menor com essa ida dele pra cidade X pro trabalho dele lá... e ele acaba tendo que esperar o ônibus pra voltar, então, ou seja... ele tem que ficar uma parte do tempo dele sem fazer nada... pra poder voltar pra casa. Onde ele poderia de repente tá voltando mais cedo mas, por questões financeiras, ele acaba não voltando... e eu vou pro meu trabalho... mas, assim, eu tô dentro da cidade onde eu moro... então é mais fácil se eu quiser vir em casa... eu posso vir... se eu quiser ficar na rua eu vou ficar... se eu quiser passar o dia todo no trabalho eu vou tra... depois eu saio daqui eu vou pra faculdade. Então, assim, a rotina... Ela é com... a minha, ela é mais completa que a dele. Então assim... a gente não percebe essa... essa falta, alguma coisa assim que acaba te cansando mais... eu acho que a dele é muito mais cansativa que a minha... muito embora a gente tenha mais ou menos a mesma rotina de vida, né? A gente chega... e praticamente sai quase os mesmos horários de casa... chega quase os mesmos horários... a gente praticamente chega junto. Mas, assim, acho que a rotina dele é mais desgastante que a minha... por mais que a gente... que os dois viajem... e tudo mais.

Entrevistador: E você comentou do companheirismo...

Marcos: É, o aspecto positivo que eu acho maior é esse... porque ele me ajuda bastante... ele... tudo o que eu tenho pra fazer, ele tá sempre me ajudando. Ou tudo o que ele tá fazendo, a gente vai e divide as tarefas... então se eu tenho que limpar a casa ele vai fazendo uma coisa eu vou fazendo outra. A gente acaba, ah, vou fazer um negócio... mesmo que eu não esteja a fim... ele adora cachorros e eu já não gos... eu gosto de bichos. Mas eu não teria tantos quanto ele gosta de ter... como você viu a gente tem um gato, mais vários cachorros, mais os passarinhos lá no fundo e por ele teria mais coisa. É que a gente acaba chegando... olha... ou pára ou então não vai dar muito certo não... acho que já tá no limite... então, por exemplo, acaba que mesmo que seja tarde ele quer dar banho nos cachorros... porque ele gosta de cuidar... ele não quer mandar pro pet pra fazer... ele quer fazer, mesmo que eu não goste. É uma coisa que eu não gosto mesmo, entendeu? Eu acho que o companheirismo enca... encaixa realmente aí... de repente é algo que você menos gosta de fazer e você faz...até mesmo pra auxiliar nas tarefas do dia a dia, mesmo estando cansado, sabe? Chega sexta-feira... ele às vezes... bem mais cedo mesmo... ele... independente de esperar o ônibus,chega mais cedo pra deixar a casa mais ou menos organizada, pra no outro dia a gente tá fazendo outras coisas... ter mais tempo... quando ele poderia muito bem ficar em Ribeirão... chegar no mesmo horário que eu e no outro dia a gente fazer junto mas ele faz isso. Então é um companheirismo muito grande. Eu acho que isso é a base.

Entrevistador: E o que você me diria que é o mais difícil da relação de vocês? E por quê?

Marcos: O mais difícil eu acho que são os nossos gênios.

Entrevistador: Como assim?

Marcos: Eu sou muito mais genioso que ele. Eu sou muito mais estourado que ele, eu acho que o Paulo é muito mais equilibrado... pra conversar... na hora de discutir. Eu não vejo o Paulo, mesmo que eu esteja gritando, esbravejando... que é... é... da minha personalidade. Ele tá calmo... ele tá falando baixo... ele tá segurando a relação... mas assim... o que é mais difícil na nossa relação, o que é mais complicado é o gênio dos dois, sabe? É a incompatibilidade de gênios e é você ter que dispensar... abrir mão de certas coisas pra poder levar o relacionamento adiante e eu sou mais difícil de abrir mão. Ele é muito mais fácil... 
eu, o meu gênio é muito mais difícil de lidar na verdade... eu sou muito mais genioso... eu não abro a mão fácil, se a gente discute é muito mais difícil eu procurá-lo pra gente fazer as amizades... fazer as pazes e conversar e tudo o mais. E ele sempre vai mais atrás do que eu. Então eu acho que o mais difícil é a minha... é o meu gênio no nosso relacionamento. Eu acho que eu sou mais complicado.

Entrevistador: Você já me contou situações que talvez mostrem um pouco sobre como é a relação de vocês... tem mais alguma outra que você gostaria de contar? Uma situação que melhor mostraria como é a relação de vocês?

Marcos: Eu acho que o nosso relacionamento ele foi acontecendo assim... muito naturalmente... sabe? Sem nada... vamos ter que fazer alguma coisa muito além... eu acho que assim, a gente... a gente se conheceu, eu acho que foi muito natural, foi assim com o tempo o nosso relacionamento. Eu acho que ele teve que ter mais calma do que eu... porque eu tinha um problema maior familiar do que ele. Ele já era uma pessoa mais esclarecida, como se dizer, com relação a homossexualidade. E pra mim isso era tudo muito novo. Eu me, eu resolvi minha sexualidade muito mais tarde do que ele. Aos meus vinte e quatro anos que eu resolvi realmente que eu queria que... que... quem era eu... né? Eu acho que é você se descobrir... então isso pra mim foi mais complicado administrar até mesmo pela minha família. Eu tenho uma família muito grande onde todo mundo já é muito velho. Não digo velho, mas assim.. um pessoal de uma cultura mais arraigada... um pessoal mais... mais... conservador... e deixar isso muito claro sem que se chocasse ninguém... muito embora isso já tinha acontecido com a minha irmã... porque ela também é... é..... e pra eles foi um choque porque eu vivenciei isso. Ela fez isso aos dezesseis anos. Eu acho que eu gostaria até de ter um pouco de coragem como ela tem... mas eu não tenho, eu acho que eu sou muito mais tranquiilo, levo as coisas muito mais... deixo as coisas acontecerem muito mais naturalmente. Acho que isso choca menos... eu acho que você consegue conquistar o mesmo ah... conquistar mais facilmente... sem que tenha que ter maiores proporções... então o nosso relacionamento foi acontecendo muito naturalmente. Eu conheci aos poucos... todo mundo foi tendo conhecimento do Paulo. Eu sempre ia pra cidade então eu sempre falava dele na minha família... sempre assim com muito... com requisitos muito fortes... da personalidade dele, sabe? Uma pessoa culta, uma pessoa sincera, uma pessoa que sabe se comportar nos lugares, inteligente... então, assim, são quesitos de um ser humano que eu...que eu primo por isso... sabe... então eu gosto de pessoas assim... então ele era uma pessoa super falada dentro da minha família sem que as pessoas até o conhecessem... ou as poucas que conheciam... e as poucas que a conheciam tinham realmente certeza disso quando ele... eu tive a oportunidade de apresentar.... então ele veio como um amigo e aos poucos todo mundo foi respeitando ele. Era exatamente isso que eu queria. Então, assim, ele soube...é... na verdade administrar essa situação e isso foi muito bom. Eu, assim, até... é...acho que ele nota que... que não precisou eu chegar e falar: olha, esse é o meu namorado. É... que ninguém sabia até... aliás eu nunca fui de sentar e conversar nada disso. Mas hoje todo mundo... todo mundo pergunta. Se eu chego, cadê o Paulo? Onde ele tá? Que que ele tá fazendo? Então todo mundo se preocupa e hoje todo mundo sabe, tanto é que os meus primos... eles conversam, chamam, já chamam ele junto... os convites de casamento já vêm no meu nome e no nome dele, sabe? As festas que têm, sempre no meu nome e no nome dele... sempre estendido a ele... e da família dele pra mim. Então, assim, foi tudo muito naturalmente mas ele teve muito mais paciência de ter que administrar isso. Porque pra ele isso já era muito natural e não tinha que fazer nenhuma cara... ou nenhuma situação pra poder vivenciar isso. E ele teve paciência de tolerar tudo isso... então isso foi muito bom.

Entrevistador: E, Marcos, o que você poderia contar sobre a sua família de origem?

Marcos: É... a minha família de origem... na verdade, a minha famí... a família que eu considero realmente a minha família são os meus pais e meus irmãos. Tem os familiares, né? 
Os... os próximos e... mas eu vivi muito mais com os próximos do que realmente a minha família em si... meus pais se divorciaram... eu era muito novo, né? Quando os meus pais se divorciaram eu era um menino, minha irmã era criança. Meu irmão tinha um...e... na atual circunstância minha mãe se casou muito cedo. E logo depois de nós três nascidos eles acabaram se divorciando por questões próprias dele... então, assim, uma família... como eu vejo família... pai, mãe e filhos... Não que hoje eu vejo isso dessa forma... até mesmo porque pode existir dois casais homo... um casal homossexual que vai ter sua família, seus filhos e tudo mais. Então não falo que é a presença de um pai homem de uma mãe mulher que é a família. Mas eu falo que a família é feita disso e então isso foi desmembrado muito... muito cedo. E isso pra mim... nós fomos criados da mesma forma, todos os três, e eu acho que eu fui o mais maduro de toda... de todos os três. Não por ser o mais velho, mas eu sempre vi com outros olhos toda a situação de uma vida... e, assim, meu pai sempre foi muito doente... e sempre foi doente, sempre precisou de tratamentos muito sérios. Foi transplantado e nesse meio tempo e quase o decorrer da vida inteira dele... enquanto ainda vivo, nós moramos com uma tia, que é uma irmã dele, que não é casada, e essa tia cuidava dos meus avós... do pai e da mãe. Então nós vivemos nesse âmbito familiar: minha avó, o meu avô, minha tia, meu pai e os meus três... meus outros dois irmãos... a família foi constituída nisso. Mas nesse tempo eu acho que eu passei por um amadurecimento precoce... até mesmo por... por pre... por... é... por vontade minhas mesmo. Por querer crescer mais cedo, por querer ter a minha individualidade, o meu espaço, e não ter que ouvir certos tipos de coisa. Até mesmo porque, quando eu morei com a minha tia, realmente, ela foi meio mãe. Mas ao mesmo tempo ela foi meia mão de ferro, então a gente não precisava de repente ter passado por algumas situações... ouvido algumas coisas, assim, são mágoas, de repente... que a gente traz... mas que eu... eu... mesmo assim eu gosto muito dela. Ela fez muita coisa, mas também disse muita coisa que não tinha necessidade. Então o meu âmbito familiar... eu acho que eu cresci assim... dentro de uma família mas eu vivi muito mais isoladamente nessa família... até mesmo porque o que... eu queria as minhas coisas, tive sempre próximo do meu pai. Meu pai na verdade é um espelho de vida pra mim... por mais que ele foi doente...teve... teve os problemas dele de saúde... mas ele foi um pai muito presente, ele sempre teve junto, ele sempre auxiliou, ele sempre foi pai e mãe ao mesmo tempo e era uma pessoa que... tudo pra ele tava bom por mais que algumas coisas acontecessem ou magoassem. Ele ficava na dele. Então ele agüentou muita coisa sozinho... e... sei lá... a honestidade... a força de vontade... mesmo chegando doente, ele trabalhava... é... não era problema pra ele. Eu sei que a pessoa chega destruída de uma sessão dessa de quimio... e... nem isso derrubava, sabe? Então ele é, assim, eu tenho nele uma base de vida, um espelho de pessoa. Meus irmãos já não são tão assim... Eu tenho meu irmão, ele é extremamente trabalhador, tem a família dele hoje, tem os defeitos dele e algumas coisas até eu critico pra ver se de repente ele cresce... na verdade meu irmão foi sempre muito paparicado. Aos treze anos, quando o meu pai faleceu, que ele tinha na época... ele não sabia o que era tomar banho sozinho, dormir sozinho ou comer sozinho... ele sempre teve ao lado do meu pai... junto com meu pai... ele foi muito mais o meu pai, ele viveu muito mais a vida do meu pai...e... e isso pra ele acho que foi uma perda muito maior do que assim... pra nós, pra minha irmã e pra mim que a gente era mais desligadão... Lógico, é uma perda, é uma perda muito grande...mas a gente consegue administrar acho que com mais facilidade do que na cabeça dele isso...e... é... assim... eles não têm, assim, muito pé no chão e às vezes a gente precisa dar uma sacudida... e o meu irmão, às vezes, eles entravam em atrito por causa disso... porque eu queria paparicar... eu queria fazer... é... como se o meu pai estivesse, como se ele estivesse presente na vida dele fazendo as mesmas coisas... claro... É certo? Errado? Não sei... mas eu queria suprir essa falta, sabe? O meu irmão sempre foi muito... quase um...como se dizer? Um bibelô de louça... que se caísse no chão, quebrava e eu continuei com tudo isso... eu não conseguia desvincular essa imagem... ou esses feitos do meu pai pra ele. A minha irmã ela sempre foi muito... eu falo... muito rebelde...né? Ela, adolescente, ela chegou pra família inteira e falou que ia morar com uma menina. É isso que eu quero, quer vocês aceitem ou não, é essa a situação. Todo mundo ficou muito.... ficou todo mundo estarrecido porque ninguém 
imaginou essa atitude dela... porque era uma menina tratada também como um bibelô e ela era uma coisa que ninguém podia muito tocar que quebrava... sabe? E de repente ela fez assim... e hoje você vê ela... você não acredita que foi uma menina que foi criada dessa forma, nessa modalidade, mas, assim, o teor da família acho que é isso... sabe? Você viver um pelo outro... né? Dentro da família... como isso aconteceu na minha vida inteira... e a minha vontade era que realmente toda aquela estrutura familiar fosse o pai, a mãe, os filhos... todos juntos e isso crescesse junto... infelizmente, em algumas situações, isso não é possível... eu sempre quis ter a minha mãe perto de mim... sabe... eu nunca me afastei dela por mais que... de todas as situações da família o que aconteceu... era de que ela se tivesse... ela fizesse com que ela estivesse sempre longe e pra mim não era assim, pra mim era que ela estivesse sempre perto... a gente tem os nossos atritos, sabe? Eu sei que às vezes eu sou estúpido mas é o meu jeito de ser. E eu sou muito mais estourado. Eu às vezes vou agüentando, vou agüentando, quando eu vejo, eu explodo. E aí eu não sei conversar, eu vou explodir mesmo... e.... mas assim... eu sempre quis ela perto... tanto é que quando ela, eu pude trazer ela pra minha casa... quando eu separei da casa, ela veio... e eu acho que ela gostou de tudo isso, que ela pediu pra vir pra cá... e veio... claro... e isso não era problema nenhum... Vem, claro, pode vir. Veio e mora com a gente até hoje, já fez quatro anos que ela tá aqui com a gente.

\section{Entrevistador: Hum.}

Marcos: Ela e o Paulo se dão super bem... um fica cutucando o outro o dia inteiro... então isso até é às vezes motivo da gente ficar bri... brincando... porque eles brincam o dia inteiro e às vezes ele tem, tem semana que ele tem que ficar fora da cidade a semana inteira... aí ela fala, nossa, mas é muito ruim aqui sem ele... então, assim, e... e ela percebeu tudo isso. A gente sentou e conversou... ela sempre me respeitou muito, a gen... eu sempre respeitei ela... é... e a gente vive assim... numa harmonia bem legal... sabe? Meu irmão respeita muito ele... então, assim, a minha vida familiar que hoje é a real que é a minha mãe, os meus irmãos e os meus sobrinhos que eu primo realmente...é..é... o familiar pra mim é isso e a família dele que são os irmãos dele e a mãe dele... é muito tranqüilo, eu acho que é assim, é de muito amor um pelo outro, de muita dedicação um pelo outro, de muita preocupação um pelo outro... sabe... é muito assim.

Entrevistador: E como é que... como é que foi pra você a decisão de morar juntos?

Marcos: Pra mim foi complicado... porque eu sempre achei... é... administrar essa situação muito difícil. Eu convidei ele pra vir pra cá. Eu acho que não teria nenhum problema ele vir pra cá. Mas a... tinha o problema do meu irmão que morava comigo na época e eu nunca tinha conversado nada com ele sobre isso, como nunca sentei pra conversar até hoje... mas claro que ele já sabe de toda a situação e tem algumas coisas que são muito claras e você não precisa ficar dando satisfações... e vir pra cá... pra mim era uma complicação muito grande, assim, eu via como uma complicação muito grande de ter que tomar cuidado com algumas situações pra que não desres... ou não desrespeitasse ou que eu não ficasse constrangido e muitas vezes, muito menos ele... e até mesmo não precisava... mas aí conversei com meu irmão. Expliquei a situação dele como amigo na época e se ele se opunha dele vir pra cá... em momento algum ele falou... Claro, manda ele vir pra cá, ele fica o tempo que for preciso, a gente tenta arrumar um serviço para ele... Então, quer dizer, ele ajudou nessa situação... e aos poucos ele foi percebendo e ele nã... acho que nunca entrou em nenhum conflito, sabe? O problema do... da... dele vir pra cá, na verdade o meu irmão ficou com muito ciúmes... porque toda a atenção quando a gente estava junto era voltada pra ele... até mesmo, como eu te disse, pra suprir a falta do meu pai... e... ele tinha muito... ele é muito ciumento com as coisas dele. Então ele via como se fosse... que eu tivesse que dividir a minha atenção com ele também... Então toda a atenção já não tava mais voltada pra ele. Então o grande problema do meu irmão com o Paulo era a questão de ciúmes... Então eles brigavam, acho que muito mais por causa disso, então eu tirava algumas coisas, não fazia mais,.então isso acabou criando 
alguma confusão assim... eles tinham as ranhetices deles mas nada muito maior não... mas é... foi tranqüilo... meu problema era a minha insegurança em ter que trazer o Paulo pra cá e tomar cuidado com algumas atitudes minhas e dele. Acho que... eu acho que eu segurava muito mais tranqüilo... eu tinha mais medo dele (risos). Pra ele era muito natural e pra mim não... e... mas depois isso foi muito sossegado. Isso foi muito tranqüilo ele vir pra cá... eu fui amadurecendo mais essa situação... isso foi sendo digerido com mais facilidade e hoje eu encaro isso muito tranquilamente... até tem algumas coisas que ele fala: calma, não é assim, eu não tô nem preocupado com isso. Então eu sou mais tranqüilo hoje do que ele, às vezes ele quer tomar mais cuidado do que eu... então eu não ligo mais. (risos)

Entrevistador: E você tem acompanhado esse debate sobre adoção por casais gays?

Marcos: Eu tenho lido algumas reportagens de algumas situações que têm acontecido. A gente tem acho que um... um caso perto aqui... acho que é. Que tem um casal homossexual que casou... uma cri... é... teve a adoção de uma criança... passou até no jornal, foi... então, assim, algumas situações eu tô... é... essas reportagens sempre quando eu tenho acesso, eu sempre leio... sempre tô inteirado, que às vezes tem algum debate até em sala de aula que me... eu quero conversar... mas é meio complicado isso... sabe? Entrar mais na questão do debate em sala de aula... porque na área em que eu trabalho isso está muito em voga... então isso é assunto de quase de todo dia. Às vezes eu quero discutir e eu tenho medo de segurar a situação, porque eu não posso entrar muito no mérito porque... como é que você sabe tanto? $\mathrm{E}$ as pessoas sempre querem saber, não que eu não tenha, que eu tenha medo de virar pra pessoa e falar que eu sou homossexual. Qual o problema? Não... não é esse o problema... até mesmo porque eu já tive amigos meus da sala de aula que perguntaram e eu falei, muito embora eles dizem que não acreditam mas problema deles, isso foi esclarecido. Então, assim, eu entro... como eu te disse, eu queria focar a... o meu trabalho de curso voltado pra essa área... a parte de adoção, a parte de... hoje a gente tem a adequação de sexo... que é um assunto que tá muito em voga, né? Então... não tem lei específica pra isso... hoje a gente tem... é... o contrato entre homo... é... entre casais homossexuais, né? Mas é tratado como um casal de... como se fosse uma empresa. E não é, na verdade... é uma relação... né? Como qualquer outra. Até mesmo porque a gente tem na cúpula ministerial pessoas muito velhas, de conceitos muito antigos e de... de uma base quase que não se dá pra fazer nada... então isso acho que tá muito... a mudança das leis tão muito pautadas nisso... então... acredito, assim, que precisa ter uma... um rejuvenescimento na área jurídica pra que algumas coisas pudessem começar a acontecer.

Entrevistador: E, me conta, quais aspectos te chamam mais a atenção nesse debate?

Marcos: Olha... o aspecto que chama mais atenção é que... é como eu te disse... como quando você não chega até o... até os ministros do Supremo Tribunal Fed... de justiça... o STF... eu acho que o assunto é mais tranqüilo... tudo é mais, é tratado com... tem uma disci... a disciplina é tratada com mais flexibilidade... tanto é que hoje a gente já tem alguma jurisprudência voltada com... com relação a isso... eu até acredito... eu acho que o casal homossexual, ele tá muito evidente... a sociedade por mais preconceituosa que ainda seja e resistente com relação ao assunto... eu acho que ela ainda, mesmo assim, ela tá muito mais flexível e muito mais fácil de se.... de se adaptar com a situação do que há tempos atrás... então eu acho que o nosso judiciário... a questão homossexual... a relação homossexual... o casamento homossexual... a união homossexual... eu acho que ela vai ser muito mais... eu acho que, juridicamente, leis vão começar a surgir muito mais rapidamente do que o próprio judiciário acredita... até mesmo por ser uma questão muito presente, muito mais atual... é... você não precisa... Quando você se depara com uma pessoa que você tem... que acredita que seja gay... hoje você vê isso na sociedade muito mais aflorado que antigamente... as pessoas eram muito mais enrustidas. Elas tinham muito mais medo do que a sociedade fosse pensar, do que a sociedade fosse tratar o gay... e hoje não mais. Hoje as pessoas são muito mais 
tranqüilas com... claro... tem pessoas de família muito mais... como se diz... de conceitos muito mais arraigados mas hoje as pessoas tão muito mais abertas à situação do dia a dia.. a... a... ao cotidiano... então isso eu acho que tem sido muito mais... tratado muito mais facilmente... eu acho que a questão homossexual ela vai ser muito melhor... vamos dizer... digerida na sociedade... do que... acho que as pessoas que tão lá em cima acham... acreditam que vão... que vá se... Eu acho que leis vão surgir muito mais facilmente, o casal homossexual vai ter muito mais sua liberdade na sociedade do que... eu acho que a aceitação do homossexual... aceita na... perante à sociedade... você ter mais liberdade... eu acho que isso não... mas os seus direitos, eu acho que sim... eu acho que isso vai acontecer muito mais ra... muito mais presente.

\section{Entrevistador: E o que é família pra você?}

Marcos: É aquilo que eu te disse anteriormente... eu vejo família: um pai, uma mãe e os seus filhos... isso é uma... pra mim é família... e... e o laço afetivo entre esses seres... claro... claro que, como sendo homossexual, eu não vejo que o... a família é criado por um pai, uma mãe e seus filhos... mas eu vejo que a família é formada por dois seres que administram um filho ou seus filhos dentro de um laço afetivo... eu tenho a intenção de adotar... eu sempre tive... sempre tive vontade de ser pai... não... por vir de mim mesmo... até poderia ser mas eu falo que se eu quis realmente... quisesse um filho meu mesmo já teria feito há muito tempo atrás, não faltaram oportunidades... é... eu acho que eu nunca fui maduro pra ser pai. A minha sobrinha morou comigo algum tempo... e... e isso me provou que eu ainda não estou maduro pra um filho... pra ter uma criança, pra poder administrar isso... Mas eu tenho vontade de adotar uma criança... da gente constituir assim, digamos, uma família, né? Que eu acho que é a continuidade de um casal. Eu acho que vem daí... eu acho que a família... é.... o significado de família é a continuidade da vida. Eu acho que é isso... o significado de uma família, eu acho que é continuidade de vida. Do mesmo jeito... do mesmo jeito que eu respeito algumas atitudes ou algumas... alguns pensamentos do Paulo... ele até... ele reluta um pouco com... com relação a essa... a esse meu pensamento... mas eu acredito que a longo prazo isso pode acontecer, até mesmo porque hoje a gente não tem tempo pra ter... pra dispensar pra uma criança... uma criança, ela tem que ter atenção, ela tem que ter carinho... ela tem que ter as pessoas que... que, vamos dizer, que cuidam dela ou que a puseram no mundo mais próximas dela... até mesmo pra ela criar conceitos, crescer e você mostrar pra ela... não é de repente... Ah, tudo bem, eu posso ter um filho... eu contrato uma babá e deixo ela com uma babá, chego de noite, ela tá dormindo, saio de manhã, dou um beijinho. Não é assim... não vejo por esse prisma... então acho que hoje eu não tenho tempo pra isso... e como eu acredito que nos meus próximos anos não vou ter também... e eu já... eu tenho assim pensamento de... de ser... minha carreira... eu vou ter alguns pela frente comprometidos com os meus estudos... então eu acho que isso é alguma coisa pra mais pra frente... mas eu penso em adotar uma criança e dar continuidade na nossa família.

Entrevistador: E você teria algum tipo de critério para escolher uma criança para adoção?

Marcos: Não... eu não tenho... de repente as pessoas falam... porque to... o casal quer uma criança branca, outro quer uma criança negra, outro quer uma menina, outro quer um menino. Eu não tenho esse preceito... não sei se é essa a sua pergunta mas eu não tenho... é... se tem que ser recém-nascido... se tem que tá com cinco anos... mas eu acho que, assim, eu queria uma criança independente da raça, da cor, do sexo, isso não me importa... mas que fosse criancinha, um recém-nascido de poucos meses... isso sim, eu gostaria... porque eu acho que a... a.... não sei, posso tá enganado... não conheço muito de psicologia... mas eu acho que a formação da criança está nos seus primeiros anos. Ele é mais flexível... eu acho que eu sou mais mão de ferro na criação de uma criança... não que uma criança não possa fazer isso... não pode fazer aquilo... se você tem que deix... restringir a criança... não... mas ela tem que ter seus limites e eu acho que o pai e a mãe ou as pessoas que criam essa criança 
é que dão isso... é! Então, por isso que eu te digo, não tenho que pegar uma criança e dar pra uma babá criar. Não é assim... ela não é a mãe da criança. Ela é uma pessoa que eu contratei pra cuidar mas eu tenho que tá mais presente e o Paulo, no caso, se fosse a situação, teria que estar mais presente... então nós teríamos que tá presente nessa criança pra fazer a base estrutural pra ela crescer, independente se mais pra frente ela vai ter uma sexualidade diversa, isso não me importa, de jeito nenhum mas também não... não... não primo pelo sexo... se vai ser menino ou menina... não primo pela raça, de jeito nenhum... até mesmo porque eu tenho um sobrinho loiríssimo, como nós éramos quando criança, e tenho uma fi... uma sobrinha negra... que é a filha da minha irmã... então já tive relacionamentos com negro, já tive relacionamentos com branco, então não tenho nenhum preconceito em relação a isso... isso pra mim não é nenhum problema... mas que eu queria que fosse um recém-nascido ou uma criança de poucos meses de idade. Isso sim.

Entrevistador: Ok, e tem algo que eu não perguntei que você gostaria de acrescentar ao que a gente conversou?

Marcos: Talvez o trabalho É... meu trabalho sempre foi uma preocupação muito grande por isso que eu te disse... eu acho que as coisas acontecem muito naturalmente... por isso, que eu falo, não precisa você chegar pra todo mundo e gritar eu sou homossexual. Cada um... eu respeito a atitude de cada pessoa... eu acho que cada um tem a sua individualidade... trata ela como bem entender mas eu tenho os meus preceitos e eu acho que, eu penso dessa forma, eu acho que você não tem que de repente agredir as pessoas. Acho que a sociedade... ela é... ela ainda é preconceituosa pela... pelo começo dos homossexuais... eu acho que tudo teve que ser muito... era...era... tem muito tabu ainda na sociedade... e as pessoas, de repente, elas gritam, né? Pra todo mundo: olha, eu sou gay e aceite se quiser. Não é assim... eu acho que você pode mostrar pra todo mundo que o gay é uma pessoa normal, né? Não precisa ser um travesti... nem todo mundo é um travesti, nem todo mundo é um transformista, nem todo mundo é um transexual, então você pode trazer isso pra sociedade com muito mais naturalidade... como aconteceu comigo e com o Paulo, pra minha família, pros meus amigos e dentro do meu trabalho. Hoje eu acho que, eu acredito, que toda a parte administrativa de onde eu trabalho... inclusive até as... as... saibam de mim como homossexual... e me respeitam como tal... é! Porque eles tratam... por exemplo, o Paulo, como a minha família trata. Se eu chego pra uma festa ou um churrasco, por mais que seja restrito à administração, ou a uma sala onde eu trabalho, todo mundo pergunta como ele está. Tem pessoas, profissionais do cargo de gerência ou de diretoria que perguntam sempre dele. Ah, e o Paulo? Ainda tá trabalhando fora da cidade? O que ele tá fazendo? Então eu não sei se pra eles o critério é de amigo... Acredito que não, mas a grande maioria dos que são mais próximos de mim, sabem... que perguntam dele, se a gente tá bem. Então, se a gente tá bem, inclui ele dentro da minha vida... não como um amigo, né? Eu acredito. Então eu acredito que assim... como muita naturalidade eu deixei isso muito claro que eu sou um homossexual e que eu não preciso... não preciso dizer e chegar pra todo mundo e dizer que sou homossexual e, se vocês quiserem engolir, é assim... Não, e todo mundo me respeita. Tanto que é que algumas brincadeiras com relação a isso deixaram de acontecer. Acho que quando eles tiveram certeza disso... e daí eles passaram... eu acho que... acredito que eles... passaram a respeitar isso. E perguntam dele com muita frequiência, quase praticamente que todo dia, a secretária executiva da empresa é uma pessoa que me pergunta todo... quase todos os dias dele... a copeira também... acho que ele nem conhece... mas ela sabe e ela pergunta com muita frequiência... sabe... e ela até às vezes... ela até chega no âmbito de falar: eu acho interessante como você tratou tudo isso porque eu sei de você, mas não porque você chegou e falou, mas porque as coisas foram acontecendo e a gente foi percebendo... e não precisou você falar. Eu... e tanto é que ela...é... ela é casada, tem seus filhos e ela até tem esse mesmo pensamento que eu...é... não sei porque as pessoas chegam e já chegam agredindo... porque pra eles é uma agressão... não sei se visual ou da sociedade ou de precon... de preconceitos... mas ela acredita que poderia acontecer com muita naturalidade, chegar e deixar as coisas 
acontecerem. As pessoas vão perceber, isso acaba sendo percebido. E não precisa você chegar e falar que eu sou homossexual, se quiser aceitar ou não, se quiser continuar meu amigo, você continua. Então no meu âmbito de trabalho isso também foi assimilado dessa mesma forma... da forma que eu gostaria que realmente fosse e que foi... então... é... No trabalho é complicado... no meu trabalho ainda é uma empresa, muito embora grande, mas muito familiar... então, onde o dono... por mais que nós tenhamos mais de mil empregados hoje, o dono consegue conhecer praticamente todo mundo até pelo nome... então, assim... é... ele fez muita parte da minha família também. Quando meu pai faleceu, ele teve muito presente, me ajudou muito...e...e acho que também ele sabe... também me respeita com relação a isso...e... e sou muito próximo até mesmo dele... Então não acho que... o grande problema hoje também da sociedade é no seu âmbito de trabalho... ter muito cuidado com relação a isso porque ainda tem muitas empresas que não admitem, né? De repente você não deixa isso claro e isso passa a ser percebido e, de repente, você tá demitido... e tem empresas que realmente não aceitam... e tem empresas que podem passar a aceitar como a minha, que eu não conheço nenhum caso lá dentro sem ser o meu, entende? E não fui demitido por isso. Entendeu? Deixei claro que o meu ambiente profissional é o meu ambiente profissional... e a minha vida pessoal é a minha vida pessoal... e as coisas não fo... não foram misturadas... é... e nem por isso fui demitido... muito embora não conheço nenhum caso... e isso era meio que um tabu lá dentro... sabe? É... mas eu acho que âmbito de trabalho também é uma coisa muito complicada. É isso.

Entrevistador: Ok, muito obrigado pela entrevista e por me receber. 


\section{6 - RODRIGO}

Rodrigo: entrevistado.

Décio: companheiro do Rodrigo.

Entrevistador: Então vamos começar falando um pouco sobre a tua história com teu parceiro. Se você fosse contar um pouco da tua história, eu queria que você contasse um pouco dela começando por onde você quiser, e fazendo os destaques que você quiser sobre essa história.

Rodrigo: A minha história no começo com o Décio é... antes de eu conhecer o Décio eu tinha tido dois outros relacionamentos, né? E... eu sempre fui, assim, em busca de um relacionamento sério, de um relacionamento... nunca entrou na minha cabeça esse negocio de ficar. Ficar pra mim nunca entrou, e achei dificuldades nos dois primeiros relacionamentos, porque imaginava que fosse ser uma coisa séria o primeiro, não foi. $\mathrm{O}$ segundo também não foi. Aí foi que eu me vi... desesperado, que eu comecei assim a imaginar que era muito complicado, assim, esse mundo homoafetivo, homossexual, é... embora eu mal tava me assumindo, já me senti perdido, né? Tava complicado relacionamento sério e todo mundo falava que era difícil mesmo alguém ficar com alguém sério. Aí eu resolvi... ir a uma igreja de crente, Cheguei lá, me abri com o pastor, tudo, o pastor chegou a falar pra mim que era obra do Satanás. Não sei o quê e tal, tinha como eu mudar. Aí eu peguei e falei pro pastor: mas como que eu vou mudar, se eu não sinto nada por mulher? Aí ele falou assim: olha, se você entrar lá na Bíblia, olhar a... tem muitos que... num sentiram nada por mulher e eles dedicaram a vida pra Cristo, então ele falou que eu deveria ser missionário e tal, né? Aí eu peguei e comecei a pensar... mas como que eu vou ser missionário, como que eu vou trabalhar, como é que... eu vou ficar só pregando a palavra, do que que eu vou viver? Comecei a pensar comigo mesmo, né? Aí eu... foi... tive uma conversa com o pastor também, ele falou que a primeira coisa que eu tinha que fazer era largar também a minha profissão. Aí eu comecei a ficar desesperado, entre a cruz e a espada, né? Aí comecei pensar, pensar, num sabia... e isso foi, assim, uns quatro meses mais ou menos, e eu já quase abandonando mesmo a minha profissão, aí foi quando o Décio... Várias vezes ele mandava recado pra mim, mandava recado que era pra mim trabalhar com ele. E eu naquela duvida, já suspeitava que o Décio era homossexual e eu num queria mas... nem pensar em ser homossexual, porque os meus primeiros relacionamentos já tinham... estava desiludido já, não queria mais nada, né? Da vida de homossexual.

Entrevistador: Vocês se conheciam há quanto tempo?

Rodrigo: Conhecia o Décio só de vista... até essa época. Aí foi eu conheci, no desespero, na hora que bateu o desespero mesmo, necessidade de trabalhar, ganhar dinheiro, né? Minhas contas foram chegando, não teve jeito. Aí eu fui conhecer o Décio, passei a ser empregado do Décio, foi aí que o Décio simpatizou comigo. me falou que empregado ele não queria mais. Todo mundo entrava, ninguém parava trabalhando com ele... virei sócio do Décio. E foi muito complicado pra mim esse começo de relacionamento porque o Décio tinha uma namorada, né? E essa namorada já tinha vários anos que tava com ele, e eu e o Décio não teve jeito, a gente passou a se gostar mesmo. E o Décio começou a cuidar de mim, assim, de uma maneira muito especial. Ele saia com a namorada, ele fazia questão que eu estivesse sempre perto. E o amor foi surgindo, né? E nisso ele... eu e o Décio começou a ter o... nosso relacionamento, começou a levar a frente. Ele se abriu com a namorada, a namorada cheia de preconceito, jamais aceitava a história, e num queria largar dele de jeito nenhum. Então sofremos muito nessa parte da nossa vida. E a namorada... sempre jogava... até aí o Décio não tinha uma terceira filha biológica com ela né? Não tinha. Ela sempre jogava que os filhos biológicos do Décio iam ter muito preconceito... do pai ser gay. Mas. Foi correndo o ano, até mesmo eu às vezes ficava com medo se... com todo o preconceito que ela jogava em 
cima de nós, eu tinha medo. Achava que poderia realmente a gente passar por barreiras. Hoje a gente já tá bem adiante dessa história tudo... e foram passando os anos, passando os anos e ela mesmo assim não desistia do Décio e... acabou até engravidando. E os filhos biológicos do Décio sempre moraram com a gente. E sempre aceitaram muito bem... que a gente vivia junto. Ela era menina na época. Eu e o Décio começamos o relacionamento assim, vivendo uma família. Essa época pra nós foi muito difícil, a sociedade muito cheia de preconceito, falava: Décio, você é um homem, tão lindo, tão bonito, você tem 3 filhos. O Rodrigo não vai ter família, nunca vai ter família, então porque que, Décio? Vai, vai curtir seus filhos, volta com a sua mulher, seja homem, tal... sempre o povo colocou um ponto de interrogação na nossa vida. Sempre... e a gente querendo ou não, a gente acaba... quando você tem a sua vida mal definida, mesmo que você tá resolvido, mas... às vezes você acaba... a gente acaba sendo mal... definido, a gente acaba pondo assim uma parte nossa da mente dentro do guarda roupa, deixa lá, né? A gente acaba vindo daqueles preconceitos que a sociedade... passa pra nós e a gente passa a sofrer com isso também. Sempre teve muito dúvida no relacionamento meu e do Décio, mas por causa da sociedade que jogava tudo isso pra nós, né? E foi passando o tempo, a filha dele foi crescendo, graças a Deus, sem preconceito mas sofrendo preconceito na escola. $\mathrm{O}$ filho também...

\section{Entrevistador: Que tipo de preconceito? Como era com eles?}

Rodrigo: Com eles dois aí... no... a molecada, né? Que eu falo que criança não tem preconceito mas os pais passam, então... outras crianças falavam: ah, seu pai é gay, tal lugar eu num vou lá porque ele é gay, coisas que ferem uma criança, né? E os anos foram passando, o preconceito que eu fui notando... da... de lá pra cá, graças a Deus, assim, melhorou bastante. Melhorou também por causa de quê? Os anos foram, assim, ajudando a evoluir, a evoluir, mas eu sei que muita gente... aqui mesmo, dentro do Brasil é... nas sociedades, existe sim ainda muito preconceito, tem muito ainda... muita coisa pra ser vencida, né? Porque... tem muita coisa, porque o preconceito ainda não acabou, não acabou, ainda tem muito. Vai por aí.

Entrevistador: E se você fosse destacar o que é o melhor da relação de vocês dois, o que você destacaria?

Rodrigo: É... eu acho, assim, o que destaco muito na relação minha e do Décio, assim, foram os cuidado um com o outro, né? O Décio, o que destacou... que realmente se assumiu só homossexual, e não bissexual. Eu sempre soube que eu fui homossexual e o que ajudou no nosso relacionamento, que nós próprio se ajudou bastante. Nós, olhando... pra nós, não pelo preconceito da sociedade, porque enquanto eu vivi ouvindo o que a sociedade achava, eu vivi sofrendo. E hoje eu posso dizer que eu consegui... a minha alegria, a minha felicidade, felicidade do Décio, consegui viver uma família, deixando o preconceito que as pessoas tem de lado e... olhando pra mim, que eu num tava fazendo nada de mal pra ninguém, eu num tava atingindo ninguém... ninguém tava sendo prejudicado porque eu sou homossexual. E o maior destaque é... meu e do Décio... acho que foi, em primeiro lugar, a gente se amar pra superar todo tipo de preconceito das pessoas, né? Mas é difícil. É difícil porque... por mais que você não quer... por mais que você não quer ser uma pessoa grosseira, por mais que você não quer ser uma pessoa agressiva, por mais que você não quer... sofrer com isso, você acaba sendo grosseiro com você mesmo, de ser obrigado a ouvir umas coisas, calado, pra você... Então você passa a desrespeitar você mesmo, porque você vai... um exemplo... processar porque se alguém falou mal que você é homossexual? A lei não vai punir a pessoa, a lei é lenta, ou a pessoa se... se falar que uma negra é preta, é preconceito, tem pena pra isso, né? Tem anos de cadeia, não sei de cadeia. Mas se falar: ah, o fulano é um bichinha, um gayzinho... né? Se agir com... com desrespeito, a lei é... cesta básica, num sabe nem quanto, não sei nem quanto... cesta básica, a punição é cesta básica, então isso pra mim não é punir também uma pessoa que age com preconceito... 
Entrevistador: Eu acho que talvez você já esteja respondendo à minha próxima pergunta. $\mathrm{O}$ que é o mais difícil na relação de vocês é... e por que é mais difícil?

Rodrigo: O mais difícil na nossa relação? Não, a nossa relação assim... é... eu acho que é igual todas as relações, né? A gente tem os altos, tem os baixos, tem... os sofrimentos pelos preconceito, tem as crises, então... é igual... todos os casais mesmo, né?

Entrevistador: E tem alguma situação que você poderia me contar que mostra como é a relação de vocês?

Rodrigo: Eu acho assim... a relação minha e do Décio foi uma relação muito legal porque... é... nossa, a gente conversa muito. Se eu quero fazer uma coisa, ele fala não, não faz, porque agora não é o momento. Então eu não vou pegar isso como... ele tá me dando uma ordem, não. Eu vou entender, né? O motivo, então nossa relação foi sempre de muito conversar, é... mesmo depois quando fui adotar também as crianças, né? Eu fui a adotar na realidade eram três, a ex mulher do Décio, ela foi pra adotar um também, então acho... eu e o Décio íamos ficar com três, e um ia ficar com ela, mas... como a gente é igual uma família íamos estar sempre próximos, né? E nisso, o juiz, quando foi começar a audiência, começou pela exmulher do Décio. Ele sabia, também, que ela era próxima nossa, amiga, que ela... os filhos foram criados com ela sempre na mesma cidade por perto, e tal, né? Sempre a mãe foi presente. E o juiz começou a audiência por ela, né? Ela falou pro juiz que só queria uma criança, o juiz falou que um não, eram dois pra cada lado, ou eram os quatro... comigo e com o Décio ou com ela, ou nenhum. Aí eu falei, bom, eu ia ficar com três, fico com quatro, né? Então isso foi uma coisa boa que o Décio ajudou me ajudou bastante porque... o meu sonho de ser chamado de pai, o meu sonho de ter uma família, ele foi muito compreensivo, não passei por cima dele também, então é... Eu acho que o relacionamento é isso, é a estabilidade, é conversar, dialogar. Crise tem mesmo, rotina tem e... e é viver mesmo uma família.

Entrevistador: E como vocês chegaram à decisão de adotar?

Rodrigo: Eu sempre tive um sonho de... ter filhos mas não precisavam ser biológicos, num precisavam ser meus mesmo. Eu sempre imaginava que eu teria alguém que ia trabalhar em casa, ou eu ia... que ia aparecer alguém desesperada que tava grávida e eu ia falar: ah, não, vamos lá em casa e tal, eu vou cuidar da criança que vai nascer depois você dá pra mim. Mas não é fácil assim, né? Então... eu comecei a sentir a necessidade de ser pai, eu comecei a procurar, mas eu não esperava que fossem tantos. Eu tava procurando dois, já tinha até escolhido... a realidade nossa é que a gente foi escolhido por eles, não por todos, pela Clara, que respondia pelos outros. As crianças se mantiveram no abrigo porque a Clara não queria separar os irmãos, e nisso os irmãos ficaram todos juntos esses anos lá, mas os dois pequenininhos tinham, assim, muitos familiares... em cima do muro, esperando separar pra pegar. E as duas grandes nunca tinha aparecido nenhuma família pra elas, então... a partir do momento que a Clara conheceu bem o Décio, enquanto eu tava dando atenção pros meninos, quan... ela conheceu bem o Décio lá no abrigo, ela mandou uma carta pro juiz falando que gostou muito de mim e do Décio e que, se fosse pra separar, ela já desconfiada que eu e o Décio era um casal de gay, tava lá no abrigo, se fosse pra separar, ela aceitava separar dos irmãos, mando... mandando a carta pro juiz, só se fosse pra morar comigo e com o Décio, poderiam vir as duas maiores. Aí o trabalho do juiz é agregar os irmãos, não separar, o juiz chamou nós pra adotar todos, mas, ali... se caso, naquele dia também, eu falasse, não, só quero dois, com toda certeza o juiz ia dar as duas mais velha pra mim e os dois pequenininho já tinha família pra encaminhar. E aí é onde que eu escolhi ficar mesmo com todos. O Décio também... ajudou bastante, né? É, o Décio ajudou bastante, porque, pra quem já tem filhos biológicos, vim mais adotivos, né? Então... então, graças a Deus, estamos muito felizes, muito contentes mesmo e... como eu já vivi muito preconceito homossexual, como a minha 
família também era grande, eu num me acho ainda numa família grande, sabe? Porque eu vim duma família grande, vivi uma família grande, vivo uma família grande, então...

Entrevistado: Então me conta a esse respeito, como é a tua família de origem?

Rodrigo: O que valeu muito a pena foi que todos os preconceitos que eu tive foi baseado, é... imaginando também que minha família jamais ia me aceitar sendo homossexual. Tanto é que minha família, quando veio a descobrir que eu era homossexual, já faziam anos que eu vivia junto com o Décio. E... e a minha mãe já tinha, nos filhos biológicos do Décio, que os filhos dele já sabiam de mim e do Décio, meus pais ainda não sabiam, não tinha... porque nós morávamos em cidades separadas, né? Meu pai e minha mãe achavam que o Décio era sócio meu e só, né? E... anos depois descobriram. Minha mãe, igual todas as mães, teve depressão, teve muita angústia... o meu pai olhou pra minha mãe e falou: olha, ele é filho meu do mesmo jeito e... todos os irmãos, é todos os meus filhos, os meus filhos, aquele que rejeitar, não precisa nem pisar os pés em casa. Aí a minha mãe pegou, né? Olhou pro meu pai, falou assim: ai, e agora o que eu vou fazer? E chorando, naquele desespero, tudo, e, nessa choração, meu pai falou: ó véia, que ele chama minha mãe de véia, ó véia, se você não aceitar ele, então você procura um psicólogo, procura vê direitinho, que, se você rejeitar ele, daqui a pouco, pelo menos ele vive com alguém, dali a pouco ele vai tá ali na rua, vai tá se prostituindo, vai tá se drogando, vai tá se dopando... você tem que vê que ele é trabalhador, você tem que ver que ele próprio segurou essa história todinha com ele, todo esses longo anos... longos anos aí e pronto. Então, graças a Deus, graças a Deus, meus familiares aceitaram tudo, mas a minha mãe, a... ela descobriu de mim... ser homossexual... de uma forma muito injusta. A minha irmã tava grávida, a minha mãe aquele sistema antigo, né? E ela começou a entrar em desespero porque minha irmã tava grávida e minha irmã olhou pra minha mãe e falou, mãe: eu estou dando um neto pra senhora, não é motivo da senhora se desesperar, a senhora tem problema pior dentro de casa, como eu fosse um problema, aí minha mãe quis saber o que era. Ah, então vou contar logo, que a senhora tá achando que eu sô o problema já vô falar qual é o problema a senhora tem um filho gay aqui é embaixo dos olhos da senhora, a senhora tem um genro aqui embaixo do olho da senhora, a senhora tem dois netinho que tão dentro de casa direto, embaixo do olho da senhora, que quase todo final de semana tá aqui dentro da casa da senhora e a senhora nunca procuro enxergar isso. O Rodrigo é gay, a senhora nunca percebeu? Falou pra minha mãe, né? E isso... foram dois problemas duplos pra minha mãe, a gravidez da minha irmã, que tava se casando... tava assim, se casando não... tava grávida de um homem, pai de três filhos, como diz o povo antigo... pai solteiro, né? Pra minha mãe, minha irmã ia ficar abandonada, ia ser mãe solteira e tal. Graças a Deus minha irmã também tá bem e vive com esse pai do filho... primeiro filho dela até hoje, sabe? Então, mas consegui superar todos os problema da minha família e eu acho que... eu escondi da minha família à toa, eu poderia ter me aberto mais cedo isso, ter feito tudo diferente. Não precisava ter esperado a minha mãe, tantos anos depois que eu tava vivendo com o Décio, pra ela descobrir a verdade de nós.

Entrevistador: E hoje vocês estão há quanto tempo juntos?

Rodrigo: Quase vinte anos.

Entrevistador: E como é que foi a decisão de vocês de ficarem juntos?

Rodrigo: O povo, muita gente fala que não acredita em amor à primeira vista e... eu... eu acho que o amor à primeira vista, minha e do Décio, foi assim... no primeiro momento que eu fui trabalhar pra ele porque ele num tinha porque ser meu sócio, se ele era o dono do negócio e eu tinha uma pequena reserva só. Não tinha porque ser sócio dele e ele fez questão que eu fosse sócio. A primeira semana a gente já começou a nos... trocadas de olhares, ele fazia muita questão deu acompanhar ele em todo lugar que ele ia com a namorada. Ele ia 
dançar, dança de salão, forró, ele fazia muita questão que eu fosse junto. Minha mãe falava que eu tava indo, segurando vela e tal, né? Mas eu tava sempre, eu ia junto também... e nisso veio mesmo o nosso amor, veio o nosso carinho, veio a nossa atração e veio tudo com muita dificuldade. Deu mais força pro nosso relacionamento, com toda a dificuldade que teve, com o preconceito da família, esconder da família, uma namorada que ele tinha que teve que falar a verdade pra ela e, mesmo falando a verdade, ela não desistia de jeito nenhum do relacionamento. Mesmo dizendo que ele era gay e ela naquele desespero de engravidar. Eu cheguei num ponto, que essa namorada que ele teve, até... eu tinha até dó dela, do jeito que ela chegava até em mim, falando que amava ele, chorava, desesperava, todo esse drama... Então foi complicado. Foi um relacionamento complicado, mas eu e o Décio começamos, assim, muito firme... com toda essa firmeza que teve no início. A gente teve muitas incertezas, como eu já falei, de preconceito que chegou a vir pra nós até várias separações mas foi tudo separação só de boca, de corpo não, de coração e mente também não. E nem de casa também, porque eu cheguei a arrumar minha mudança uma vez pra me mudar, pra separar do Décio. E fui pra casa duma irmã minha, no mesmo dia ele apareceu lá e foi me buscar... Acabou rápido, então, eu via mesmo que a gente tinha que ficar junto, tinha que lutar junto, mesmo ramo, a mesma profissão e cada briga que eu tinha com o Décio no passado era mais por causa dessa namorada que ele tinha, que ele já tinha... da época que ele era casado ainda, né? Então, o problema era esse, agora eu tinha dó dos filhos dele, porque nossa separação os filho acabam é... acabou voltando pra casa da mãe umas duas vezes, aí eu falava assim: não, vou voltar mesmo porque eu acabo com a minha vida, acabo com a vida do Décio, acabo com a vida das crianças, as crianças não gostam de morar com a mãe biológica e vão ter que morar, então... Foi uma decisão daquelas.

Entrevistador: E me conta como é que os membros da tua família de origem se relacionam com o Décio?

Rodrigo: O bom exemplo, assim, da minha mãe, com toda essa descoberta que... que teve aí, né? Desses quase vinte anos aí que eu me assumi, né? A minha família graças a Deus aceito assim... aceitou... muito bem, né? E minha mãe... minha mãe, na casa dos outros meus irmãos, ela vai rapidinho, já volta embora logo e tal, ela se sente muito bem mesmo na nossa casa, ela... fica assim, por exemplo, meio mês, uma semana, fica... e depois que vieram as crianças também, ela vem mais ainda visitar, com mais freqüência. Ela aceitou muito bem mesmo, sabe? A minha mãe, quando o Décio perdeu a mãe dele, ela fala que... ela adotou ele também como filho. Então eu acho que foi um grande exemplo que a minha mãe teve... (entra um familiar na sala, a entrevista é brevemente interrompida e retomada alguns minutos depois).

Entrevistador: Vamos retomar, me conta uma coisa, você tem acompanhado o debate sobre adoção por casais homossexuais e sobre a união estável?

Rodrigo: Eu não cheguei... não... fora do país eu sei que já tá existindo o casamento... fora do país, nos países mais desenvolvidos, né? E dentro do Brasil nós encontramos ainda, assim, as dificuldades. É diferente, lá os países são mais desenvolvidos... o preconceito é menos, é bem menos, eu sei que existe o casamento, agora a parte da adoção, eu não sei se já é liberado... né? Não sei, mas eu acredito que... já deve ter muitos casos lá que já foi liberado para casais gays adotar filhos e aqui no Brasil o que eu tenho a dizer é, assim, que eu vi um...um juiz...né? Muito bom, uma pessoa com um coração assim muito grande que viu o desespero, né? Numa criança que queria ir pra adoção, não importava se era homossexual ou não, e o juiz que não teve preconceito por eu viver com um outro homem e aceitou o pedido da menina. Porque se fosse um juiz fechado, um juiz com preconceito jamais ia liberar, né? E ele acreditou em mim e no Décio e acreditou, assim, numa empreitada boa de várias crianças. Eu acho que foi tudo de bom pra minha vida, pra vida do Décio, pra completar a nossa família, pra mim acreditar mais nas leis brasileiras, porque eu acho que aqui no Brasil 
isso, com certeza, vai ter mais coisas boas à frente. Eu ainda não posso assim saber o quê... porque eu também não sei nem como vai finalizar o meu processo, se vai ser no nome de um ou no nome dos dois. Eu não sei.

\section{Entrevistador: Como é isso?}

Rodrigo: O processo tá correndo ainda em segredo de justiça, né? Vamos esperar.

Entrevistador: E o que é família pra você?

Rodrigo: Família? A família não importa se é duas mulher, não importa se são dois homens, não importa se é um homem que separou da mulher pra viver com uma outra mulher, sabe? Eu acho que a família é quando vivem a dois, com respeito, caráter, dignidade... A família é quando você faz ela prosperar também... a crescer, a conseguir todas as conquistas e a família faz parte também de crise financeira que existe muito, de crise amorosa, de altos e baixos, então a família é pra um ajudar o outro, né? No que precisar, então eu acho que a família tem que vencer todas as batalhas, sempre com amor.

Entrevistador: Mais alguma coisa sobre isso? Não? Então me conte, você teve algum critério específico que você usou quando vocês resolveram adotar filhos?

Rodrigo: Oh, quando eu resolvi adotar... eu fui, eu fui... saí desesperado pra escolher quem eu ia adotar, né? O que mais me surpreendeu é que eu não esperava que eu ia ser adotado, você entendeu? Eu fui adotado por uma menina acima da idade que eu queria adotar, só que... eu abri o... deixei o meu coração abrir sem olhar idade, né? Que ela era uma mocinha já acima do tamanho padrão das crianças da idade dela. Já uma mocinha e eu deixei meu coração aberto, eu fui pra escolher, eu fui de abrigo em abrigo escolhendo, tanto é que eu não tinha nem a minha inscrição em Fórum. Não tinha e, quando eu fui escolhido, eu falei: vou ficar com todos, depende da resposta do juiz, depende do que o juiz resolver, eu já fui decidido, sabe? E quando eu li o histórico de cada uma das crianças lá dentro do Fórum eu já sai, assim, amando todas elas... vontade de chorar e aquele desespero todo e não via a hora de pegar eles e proteger.

Entrevistador: O que te chamou a atenção quando você leu o histórico?

Rodrigo: Maus tratos, Luiz, uma criança desistindo da mãe biológica que teve ela... né? Uma mãe que não deu amor, que não deu atenção, não deu carinho... Muito triste.

Entrevistador: ... acho que o básico que eu tinha que perguntar, já perguntei. Tem alguma coisa que você gostaria de contar para a sua entrevista que eu não tenha te perguntado?

Rodrigo: Não, você me perguntou tudo e o que eu queria falar mais uma vez é que eu acho, eu não sei pra onde que vai, eu acho que o homossexual... a gente tem que se amar, tem que se respeitar, cada um faz da sua vida o que quiser, eu acho que todos nós temos que dizer não às drogas e à prostituição porque se droga e a prostituição fosse tão boa não tinha acabado com tanto lar. E, se eu tenho hoje uma família dentro de casa e tô muito feliz com ela... mas a gente tem que fazer um reparo, essa família foi destruída por causa da droga, por causa de destruição, por causa da agressão, então eu acho que todo mundo tem que fazer um reparo em si próprio, todo alcoólatra: ai, hoje eu vou beber só mais um pouco, o fumante fala que vai fumar só mais um pouco...

Entrevistador: Vocês tiveram um caso de alguém que usava drogas? 
Rodrigo: Na minha família não, mas na família de quase todas as crianças que tão no abrigo geralmente é por causa disso. Então eu acho que o reparo de ter que fazer isso... toda pessoa jovem hoje, né? Aproveite viver a vida sem drogas, sem se dopar, sem cachaça demais, sem exagero, né? Se respeite. Quem é homossexual, que vive junto com alguém, adote uma criança e vão saber o quanto vocês vão amar a criança, o quanto vai ser amado e essas crianças que eu tenho... eu não... eu nunca vou ter necessidade de querer ter o meu biológico, isso aí eu passo pra todo mundo porque eu conheço o amor pra eles... eles, pra mim, já são filhos meus como fossem biológicos. 


\section{7 - FLÁVIO}

Flávio: entrevistado.

Cláudio: companheiro de Flávio.

Entrevistador: Bom, Flávio,vamos falar um pouco sobre a sua história com seu parceiro, eu queria que você começasse a me contar a respeito dessa história por onde você quiser e que você fizesse os destaques que você acha que melhor representam essa história.

Flávio: Bom, eu vou falar do início, nós nos conhecemos através de amigos e... nos gostamos muito, foi muito forte, desde o primeiro dia que nós ficamos juntos, a primeira vez, não passamos mais nenhum dia longe um do outro. Tanto que vinte dias depois a gente já tava morando junto, né? ... No vigésimo primeiro dia a gente já tava... a gente já tinha alugado um imóvel pra gente viver junto, né? E isso já faz quatro anos e... no início é super difícil, a gente não tinha nada, não tinha móveis é... eu trabalhava... eu era recém formado, ganhava menos, ele também, então nós enfrentamos muita dificuldade, com a família é... mesmo assim a gente foi... fortalecendo, assim, fizemos um... uma... cerimônia de união, é, depois, quando surgiu uma oportunidade de fazer o... o contrato de união nós fizemos e hoje, até hoje nós temos assim, sempre... o que nós fizemos no dia-a-dia é... nós fazemos planos, diariamente é... constituir família, é... ter filhos... é comprar um imóvel, então, a gente tá num processo de crescimento mesmo, assim profissional e pessoal, e junto, um ajuda o outro tanto na forma profissional como pessoal.

Entrevistador: E, se você fosse fazer destaques dessa história, que momentos que você acha que poderiam ser destacados na história de vocês?

Flávio: Eu acho que, eu, como eu disse, né? Nós tem, tínhamos, vinte dias de namoro, então nós não nos conhecíamos o suficiente para ir morar junto...

Entrevistador: Hum.

Flávio: Então nós fomos nos conhecer morando junto, então eu acho que... o mais forte é isso...

Entrevistador: Hum.

Flávio: ... que fortaleceu... pra algumas pessoas, isso poderia ser... uma barreira, pra gente não que a... (barulhos de fundo) forma mais real de dizer que o amor ali existe porque, independente de como a pessoa acorda, se acorda com mau-humor, os problemas que ela vai enfrentar com a família particularmente, por que até um certo ponto, até um certo é... tempo, cada um tem a sua família, depois a gente até passa a ser... nessa família, até conhecer, aceitar a gente... mas antes não... cada um tem a sua família, é tudo muito complicado, então... o mais forte acho que foi ter certeza... do sentimento...

Entrevistador: Hum.

Flávio: Se isso é... ficou muito claro tanto um quanto pro outro, senão a gente não ia se arriscar.

Entrevistador: Hum.

Flávio: ...então o ponto forte é esse, nós... pouco tempo foi necessário pra gente saber o que a gente queria, tanto um como outro e hoje a gente fala a mesma língua, a gente tem isso, a gente fala a mesma língua, a gente tem os mesmos objetivos... e eu acho que é o, é... 
preponderante para um relacionamento dar certo, nós somos muito cúmplices, ninguém num... num sai sem o outro, não vai pra um bar, a gente não vai pra lugar nenhum, somos muito cúmplices, agente é muito é... é um dos pontos mais fortes que eu digo do nosso relacionamento

Entrevistador: E você falou... falou em se arriscar... é... quando você fala em se arriscar, que tipo de risco é esse?

Flávio: ...eu acho que... que eu digo, risco é pra qualquer casal, não é pra um casal de heteros ou de homossexuais... né? Eu acho que quando você vai morar com uma pessoa, você vai viver com uma pessoa, há grandes riscos, de você se decepcionar, de você às vezes colocar muito da sua vida e não ter um retorno... Então, quando a gente vai se entregar a um relacionamento, independente da opção sexual ou da condição sexual de cada um, é... há um risco. Eu disse, nós nos arriscamos por isso...

Entrevistador: Hum.

Flávio: Nós, é... acreditamos um no outro.

Entrevistador: E me conta uma coisa, você pode me dizer o quê que é o melhor nessa relação de vocês, o quê que você me diria que é o melhor e por quê.

Flávio: Melhor é o companheirismo mas... depois do amor, né? É óbvio, por que a gente se ama bastante, eu... demais, é... meio inexplicável. E... depois do amor é a cumplicidade, é... tá todos os dias vivendo coisas juntos... é... é gratificante isso, pra gente que se gosta.

Entrevistador: O que é o mais difícil na relação de vocês?

Fávio: Mais difícil é... hoje ainda o mais difícil é... poder viver normalmente, tipo, se a gente estiver num bar, a gente não pode sentar de mão dadas, a gente não pode é... se de repente a gente ta ali, a gente não tem o... mesmo é... respeito se fosse um casal mesmo, de heteros, que estariam ali, todo mundo olharia: não, são casados. Então eu acho que isso é muito difícil.

Entrevistador: Hum.

Flávio: Porque no trabalho às vezes a gente não pode fazer alguns comentários, sabe? Se a gente vai ao médico a gente tem que ter um pouco de cuidado... não tem aquela coisa de é... ... Eu tenho um plano médico e ele vai... na empresa, mandou chegar na empresa e dizer assim ó: ele não tem plano médico e eu quero que ele seja meu dependente, entendeu? A própria... a própria... a própria declaração do imposto de renda, né? Como a gente vivia há quatro anos juntos e somos um casal de homossexuais, ainda a legislação não deixa... não... não deixa eu declarar ele como meu dependente, então isso é mais difícil pra gente ter uma vida mais normal...

\section{Entrevistador: Hum.}

Flávio: ... porque seria mais fácil se pudesse, se as pessoas não fossem... eu poderia chegar no meu trabalho e incluir ele no meu plano médico, ele teria a mesma cobertura que eu, a mesma segurança, então isso é muito, muito difícil, muito difícil...

Entrevistador: Como, como é que vocês resolveram isso? Ou isso num, não está resolvido? Você falou de seguro... você falou de... trabalho, como é que isso ficou, como é que vocês estão?

Flávio: Não, isso é... a gente acha que... é o tempo, né? ... isso vai mudar, a gente tá vendo as... as mudanças tão acontecendo, o que a gente resolve no dia-a-dia é um apoiar o outro, como, se eu tenho uma cobertura e ele não tem, se ele precisar de um médico a gente vai pagar, então a gente tenta. A gente se ajuda assim. 
Entrevistador: Hum.

Flávio: É difícil por isso... é difícil, mas é assim que a gente tá convivendo, com a esperança de o dia, cada dia que passa ser melhor.

Entrevistador: Tá.

Flávio: É... que um dia a gente vai fazer as coisas muito mais fácil, a gente não vai precisar colocar nas entrelinhas.

Entrevistador: E... e tem alguma situação que você poderia contar que você acha que melhor mostra como é a relação de vocês?

Flávio: Uma situação? O que ela mostra... ah... é difícil falar de uma situação, nós somos... a gente gosta muito das mesmas coisas, ... muito das coisas mais, é... sérias, as coisas mais... supérfluas, vamos dizer, de coisas, de concurso de Miss (rindo)...

Entrevistador: Hum?

Flávio: Entendeu? Nós gostamos muito, a gente discute (fala rindo), diariamente, às vezes, acompanhamos isso, até... filmes, que a gente gosta também e até trabalho. Felizmente hoje a gente tá seguindo a mesma profissão, que é a área administriva de empresa, então é... tudo, então é..., acho que isso é... nosso papo, nossa conversa, a gente discute... bem... acho que mostra muito como que a gente vive.

Entrevistador: Você disse que vocês... que o concurso de Miss, vocês discutem...

Flávio: Isso.

Entrevistador: ...me conta, como, como é que são essas discussões?

Flávio: Porque desde que... às vezes, desde o início, eu sempre gostei e ele também, ah... antes, há muitos anos atrás, eu já desfilei e ele também, por isso nós acabamos gostando desse tipo de coisa, de concurso, então a gente sempre, antes... Quando nós começamos, a gente tava namorando, a gente viu que a gente conhecia alguma coisa, conhecia: ah!, a Miss do ano passado, do ano retrasado... ah! Eu também conheço. Aí a gente começa, começou a ver que, é... a... era assunto isso também, era um dos assuntos, então a gente chega em casa, então hoje às vezes a gente chega em casa: então, cê viu, cê entrou no site lá? Tem site que diariamente eles é, atualizam, falam, dão notícias, vencedoras por estado. Ah, eu vi, o que você achou dessa? Ah, eu não gostei. Ah, eu gostei. Ah, não, essa é bonita, eu gosto daquela, tal. E a Miss Brasil: ela deveria ganhar Miss Universo. Ela não deveria (fala rindo). Então, a gente não perde: a Miss São Paulo, a Miss Brasil, é muitas coisas, às vezes a gente fica bravo um com o outro (risos)...

Entrevistador: É?

Flávio: É, às vezes a gente discorda por, até por pouca coisa, e depois a gente ri, porque, que nem... teve uma vez que nós saímos do cinema, nós sentamos num bar, tomamos uma cerveja, começamos a falar de... é... celebridades e... da Adriane Galisteu. Perguntamos da altura da Adriane Galisteu. Um falava que tinha um e oitenta, outro falava que ela não tinha (risos), e afirmava aquilo horas (fala rindo). E até provar pro outro que não tinha (risos), mas hoje a gente... a... alguém começa a fazer alguma briga, alguma coisa assim perto, a gente fala: ah, não esquenta não, a gente já brigou até... por causa da altura da Adriane Galisteu (risos). Por coisas imbecis mesmo, muitas vezes. 
Entrevistador: ...tá bom, e como é, como era sua família de origem, o quê você pode me contar da sua família de origem?

Flávio:A minha família de origem? Ó... é... muito, por ser muito humilde, ser criado assim, é... não na cidade, eu mesmo nasci, é... minha... minha família não morava na cidade, morava na área rural, então a... postura que eles tinham sempre foi muito machista, então, era... um homossexual era pra eles a... aquela bichinha, era alguém que... eu cresci pensando que um gay era um cara que queria ser mulher, não era a... apenas um cara que sentia atração por um outro homem, não. Era porque queria ser mulher, né? E... foi super complicado quando minha família ficou sabendo... principalmente pelo meu pai, meu pai é muito machista, ele é machista, a família inteira, digamos assim, acredito que hoje ainda tem, saia algumas conversas entre meus primos, os parentes não tão próximos, que hoje não me interessa né?... $\mathrm{O}$ que me interessa são aqueles que cresceram mais ligados, minhas primas, que me ligam. Eu vou na casa da minha tia, hoje minha mãe vem em casa, depois de passados muitos problemas, a gente tem enfrentado muita coisa, né? Hoje é muito melhor. Então minha família de origem é... a... muito ma... era muito machista... hoje... não mais. A minha irmã mesmo, hoje, os amigos que freqüentam a casa da minha irmã, a maioria são homossexuais, né? Então é... tá a minha família hoje, eu digo que ela... aceita, minha mãe até esses dias ela vem em casa, ela comenta, fala de casos,... mas... passamos por um período difícil, por isso que eu digo que ela era uma família muito machista mais pela forma que foi criada, pelo costumes... pela orientação que teve, né?

Entrevistador: Hum.

Flávio: Até acesso as informações, não tinha tanto acesso as informações, hoje a TV tá dando até um pouco mais de... abertura pra isso e isso também ajuda.

Entrevistador: Hum. É... você falou da sua irmã, você tem quantos irmãos?

Flávio: Dois, tenho uma irmã e um irmão.

Entrevistador: Mais velhos, mais novos?

Flávio: São mais velhos os dois.

Entrevistador: E você falou do teu pai... teu pai especialmente, alguém que você diz: ele é um machista...

Flávio: É.

Entrevistador: O que você pode me contar a respeito?

Flávio: ... bom, quando ele (pai) ficou sabendo, ele me ligou, nós ficamos quase duas horas no telefone trocando ofensas né? Porque, inicialmente as coisas que ele me dizia: que ele deveria me matar, que eu deveria morrer, que eu tou envergonhando ele, coisas nesse sentido... só que nós nunca tivemos um bom relacionamento, meu pai foi meio, tem... um certo comportamento não... muito aprovado (fala rindo), digamos assim. Então eu me senti forte também pra responder, e pra poder é... bater de frente com ele, mas, graças a Deus, logo ele, depois ele se arrependeu... hoje ele... então, não comenta sobre, eu sinto que ele respeita, até o relacionamento entre a gente melhorou muito do que era há anos, hoje pelo menos ele conversa, que nem, o Cláudio ele conversa, ele olha, ele cumprimenta, ele dá a mão, ele... trata o Cláudio até melhor as vezes que... eu mesmo, a gente tinha mesmo um relacionamento difícil já antes disso, para ele é inaceitável, né? Um filho dele ser homossexual, meu pai sempre foi mais mulherengo ainda, então... né? 
Entrevistador: E há quanto tempo vocês estão juntos?

Flávio: Nós moramos juntos há quatro anos agora, no início, dia $\mathrm{X}$ faz quatro anos que moramos junto, né? Dia $\mathrm{X}$ do mês $\mathrm{Y}$ faz quatro anos que ficamos juntos.

Entrevistador: E como foi essa decisão, de vocês ficarem juntos?

Flávio: Nós começamos a ficar e no dia seguinte nós trocamos mensagem e resolvemos nos encontrar. Daí, dia a dia não conseguia ficar longe, então, às vezes, se eu não podia ficar na casa dele, era ele que ficava na minha, então tinha dia que minha mãe me ligava e falava: oh, você tem que vir pra casa hoje. Eu ia, mas à noite ele tava lá em casa, ele do... ele dormia lá em casa e, assim, no outro dia, eu não ficava em casa e ia na casa dele e nesses vinte dias de namoro a gente não conseguia ficar um longe do outro.E aí uma semana, quinze dias, logo depois, a gente tava conversando, aí ele disse: vou procurar. Ele morava com a... ele dividia o apartamento com um de nossos amigos, ele disse: vou procurar um imóvel pra... Eu falei com ele: procura um imóvel pra morar sozinho, né? Deve fi... fica complicado a gente com amigo, às vezes não é tão... morar com família é complicado, imagina com amigo. Aí ele... na hora ele falou: eu faria isso se você for... se você morasse comigo. E eu: vamos morar junto então. Aí fomos atrás de imóveis na mesma semana, na sexta-feira a gente tava morando junto.

Entrevistador: Então foi uma decisão repentina?

Flávio: É, uma porque a gente não conseguia mesmo ficar um sem o outro, então era a única saída, porque senão a minha mãe ia estressar (fala rindo) e o amigo dele também, né? Porque... não deixa de ser um inconveniente, né? Então...

Entrevistador: E como é que os membros de tua família de origem se relacionam com teu parceiro? Eu queria que, se você se lembrar, que você contasse uma situação à título de exemplo.

Flávio: Bom, no aniversário do Cláudio no ano passado minha mãe ligou pra ele no telefone e chorou, como ela faz comigo, e ela disse palavras muito bonitas... assim, até meu irmão mais velho, que é casado com uma mulher e ele não tem uma boa... convivência, um bom contato com a... com essa mulher, e ela disse, né? Ela falou: olha, eu te adoro, te amo, você também é como um filho, né? Eu considero muito mais você como da família do que a minha nora, que é casada com meu filho. Então, é assim hoje que minha família trata, se alguém liga, se minha tia me liga, se minha prima liga, se alguém me liga, sempre pergunta por ele, sempre pergunta, manda lembrança, abraço. Sempre, assim.

\section{Entrevistador: E foi desse jeito desde o começo?}

Flávio: Ó... a minha família sempre me respeitou muito e... sempre tiveram uma admiração muito grande, eu sempre batalhei, eu sempre fui, é... comecei a trabalhar, fui pagar minha faculdade, meu pai tinha os problemas dele então eu supria em casa todas a... a... as dificuldades, eu que passava por cima, eu que emendava, então minha família sempre me viu assim de uma forma de uma pessoa mesmo, é... Honesto, trabalhador, que batalha, que vai atrás daquilo que quer, e sempre muito comunicativo, sempre muito, muita afeição pela, por todo mundo, eu pude sentar e conversar, proximidade com a maioria... e... quando aconteceu que eles descobriram houve uma revolta, a princípio houve uma revolta, depois veio aquela... eu acho, não sei, por parte deles que realmente gostavam, me aceitavam. Então isso, logo depois eles já começavam a cobrar, a... você tá precisando vir em casa, precisa trazer o Cláudio aqui, aí eles começavam a cobrar, então, aí depois eles conheceram melhor o 
Cláudio, viram que era uma pessoa é... do bem, que me fazia bem, tava me fazendo bem, e assim que... que hoje, porque acredito que hoje eles tenham um sentimento por ele, entendeu? Então, foi gradativo, mas eu digo, mais rápido depois que passou aquela revolta, veio logo aquela cobrança: precisamos que... te conhecer, também, se... se é de quem você gosta nós também vamos gostar.

Entrevistador: E... me conta o seguinte, você tem acompanhado o debate sobre adoção por casais gays?

Flávio: É, acompanhamos, é... é... até agora recentemente foi um casal de Catanduva, né? De Catanduva? É, que adotou, foram os primeiros, né? A fazer a adoção, aqui em Ribeirão também um casal que adotou acho que, acho que foi três ou quatro crianças, a gente tem acompanhado, a gente tem até nomes por aí já (risos)...

Entrevistador: Já é um projeto?

Flávio: A gente já tem um nome, é um menino e uma menina, a gente quer... ... adotar daqui a uns três, quatro anos porque é o, é o, senão... passa muito tempo ele vão chamar me chamar de avô (risos). E também a gente precisa acertar algumas coisas antes, então a gente acompanha, a gente, te-tem um amigo nosso, ele trabalha em cartório...

Entrevistador: Você... precisa acertar umas coisas antes, deixa eu entender o quê. Que coisas são...?

Flávio: Ah, sim! Agente precisa ter um imóvel próprio, né? A gente precisa terminar a faculdade, então a gente precisa estar mais estável pra dar maior condição.

Entrevistador: Hum.

Flávio: E eu tava falando, a gente tem um amigo que trabalha em cartório, ele já até explicou pra gente como é que funciona, como é que é, na certidão, como vem, vem avós, não vem avós maternos, avós paternos, vem avós, vem o nome, então, achamos tudo interessante.

Entrevistador: Hum.

Flávio: A gente acompanha assim.

Entrevistador: E vocês tem contato com o casal que adotou?

Flávio: Não, nós não conhecemos, nós só vimos pela TV.

Entrevistador: Pela mídia.

Flávio: Só pela mídia.

Entrevistador: E me conta uma coisa, tem algum aspecto nesse debate específico, né? De adoção, que mais te chama atenção, e por quê?

Flávio: Olha, o que o... que eu acredito que a legislação precisa sim, é uma lei específica, com regras específicas, não é só pra homossexuais, é pra todo mundo, todo mundo que quer adotar. Então, é, o que me chama atenção não é o fato do, se o homossexual vai adotar, é o ser humano que vai adotar a criança, né? Então eu acho que a intenção, o como vai tratar, não é se é hetero, não tem distinção, acho que pode-se sim criar umas regras, um trabalho de entrevista, pra conhecer, pra saber o intuito a, das pessoas que tão adotando, a necessidade, 
pra gente... a gente adora criança, a gente gosta muito de criança, tanto eu quanto o, quanto ele, então, é necessário pra gente ter filhos.

Entrevistador: Hum.

Flávio: Então, o que chama atenção dessa dificuldade que ainda hoje impõe, que, eu acho que mais que, então até, até que acredito, acho bom a mídia trazer sim, mas deve trazer de uma forma até mais natural, e não de uma forma muito, é... explorar muito a imagem (batidas ao fundo), porque isso vai inibir muita gente também, acaba inibindo, então, não explorar tanto a imagem pra eles que, sim, estão, eu acredito que... seria bom pra todo mundo ver que eles adotaram, mas que nem a gente hoje, se a gente vai adotá, ... a gente não queria... ver a nossa imagem aí, é, na TV, porque ia ser prejudicial pra gente no trabalho. Hoje, eu digo. Não digo daqui a três ou quatro anos, que as coisas podem estar melhor, né...?

Entrevistador: Hum

Flávio: Então o que me chama atenção na adoção é isso.

Entrevistador: E te chamou atenção também então, você acha que... o que você acha da forma que a mídia cobriu a adoção?

Flávio: Não, foi bom, porque eles aceitaram. E é bom pra todo mundo conhecer. Isso é muito importante. Nossa, até pra gente, quando nós fizemos a união aqui em Y (cidade), nós fizemos reportagem, tiramos fotos, nós saímos em revista... só que a gente sabia também que era uma revista um pouco seletiva, não era pra todo público, porque... até aonde ia nos atrapalhar né? Porque infelizmente a gente tem que ter cuidado, porque senão a gente vai ser prejudicado. E... o que me chamou atenção mesmo é, é essas regras, não criar regras de adoção pra um casal de homossexuais, acho que tem que existir pra todo mundo, é igual, sê tratado igual, não é um casal de homossexuais, é igual, tem o mesmo tratamento.

Entrevistador: Bom, e me conta o seguinte, o que é a família pra você, o quê é a família?

Flávio: Sou muito apegado à família, nossa, sou demais, é... ligo pra minha mãe todos os dias, eu sinto falta às vezes de... da comida dela, eu sentia muito falta de um lar, porque, eu disse, eu tinha problemas em casa, hoje eu tenho esse lar. Então, a família pra mim é... você tá estressado do trabalho, você tem que chegar em casa e poder conversar, esquecer aquele assunto, poder tá ali num ambiente gostoso, sabe, aquela coisa de fazer coisas junto? Que nem hoje, a gente, é... vamos ali na esquina, vamos junto, vamos no shopping, vamos fazer compra, é... o, família pra mim é... é... um ajudar o outro e ter um ambiente de felicidade, né? Amor, sempre, que nem, a família que a gente, de origem, fala. A gente não escolhe essa família, né? A gente vem com ela, então a gente ama a família com todos os defeitos e quando a gente é... acha que a gente que escolhe, a gente não escolhe, mora com uma pessoa, eu não escolhi, eu também... me apaixonei, e... e... todas as famílias, por isso que eu digo, tanto a de origem quanto a família... tem a, essa... a... melhor coisa é o amor, acho que é o sentimento, não dá pra... viver num ambiente onde não existe amor, o que existe muito por aí, então isso não é família. Não é porque casou é... é... tem gente que prefere... tantos homens por aí resolveram, preferiram casar com... mulher por que era mais fácil pra família, mas são infelizes, então não há amor, então isso pra mim não é constituir uma família. Constituir família é morar junto com a pessoa que você realmente ama.

Entrevistador: Bom, a próxima seria uma pergunta se você tivesse um filho, mas eu vou fazer, né? Já que você disse que tem vontade de ter um filho.

Flávio: Tá. 
Entrevistador: Quando vocês forem adotar, vocês pretendem ou vocês gostariam de ter critérios específicos... pra escolher a criança que vão adotar?

Flávio: Não... a gente... quer um menino e uma menina, o único critério que a gente vai querer é esse (fala rindo), mas do resto nenhum.

Entrevistador: Bom, então, das perguntas básicas que eu tinha, você respondeu todas e eu ia te perguntar uma última coisa, então. Tem uma coisa que você acha que eu não te perguntei e que você acha que seria importante falar numa pesquisa como essa.

Flávio: Então, no momento eu não me lembro, porque eu falo também bastante, né? Então eu acho que falei tudo, e pode ser que eu tenha deixado de falar algumas coisas, talvez sobre... a falta de... ... filmes..., que nem, pra você ver: hoje assisti um romance gay na locadora. Tem dois na locadora, ou você não assiste...

Entrevistador: Hum.

Flávio: ...então, livros, né? Tudo tá tá ainda difícil, tá, ainda, ainda existe pouco, é, esses dias eu abri um site, existem mais de... trinta filmes, romances, num, não é pornografia... é romance, só que na locadora, se você for, só tem dois, três. Então, isso pra gente precisa de melhorar, né? Então, livros, a gente conhece o quê? É, se você vai falar da literatura brasileira, você tem diversos livros pra falar e de alguma coisa que fala de homossexualidade, temos aqui algumas obras, poucas, muita gente nem conhece.

Entrevistador: Hum.

Flávio: Então, acho que a parte cultural ainda... deixa a desejar.

Entrevistador: Ah, tá certo, então vamos combinar o seguinte, acho que foi muito boa a entrevista e eu queria te pedir: se te ocorrerem outras coisas e você quiser falar me procure, ok?

Flávio: Com certeza. 


\section{8 - DIRCEU}

Dirceu: Entrevistado.

Emílio: companheiro de Dirceu.

Entrevistador: Vamos começar falando um pouco da tua história... eu queria que você me contasse a tua história com o teu parceiro destacando aspectos que você achar que são importantes nessa história... da forma como você preferir contar...como é que vocês se encontraram... como é que vocês ficaram juntos... como é que começa sua história?

Dirceu: Então...primeiramente eu fui casado... com mulher... né? Me casei... eu era uma pessoa assim... nova... com dezoito anos... e não conhecia nem homens nem mulheres... e me casei assim... porque antigamente casava virgem... né? Casei, vivi seis anos, aqueles seis anos, assim, né? Sei lá, num, num, num sabia o que eu era... sabe, assim? Sabia o que eu sentia mas eu não sabia se... se eu ia... eu não sabia nada sobre o homossexualismo e no entanto tive a minha primeira filha, tive o meu segundo filho e depois me separei da minha mulher achando que era ela que não... não... achando que em outra mulher eu ia encontrar, às vezes, o que eu procurava... Me separei e fui morar com uma outra mulher... com quem eu tenho outra filha. Mas também não tava bem... aí o Emílio veio trabalhar... isso foi lá na (inaudível) aí ele foi trabalhar pra mim... e já no primeiro dia já de trabalho... como era difícil achar uma pessoa, assim, que fica firme no trabalho. Pra mim tava tão difícil e eu também fazia um curso à noite... à noite eu trabalhava, entendeu? E pra mim era pesado e eu precisava de alguém que ficasse trabalhando comigo de alguém que fosse, assim, firme. E ele demonstrou isso, entendeu? Quando ele chegou pra trabalhar pra mim e, até ele entrar, eu propus pra ele que ao invés de ele trabalhar... Uma sociedade que eu sabia que ele ia ficar mais firme ainda. Aí ele se tornou sócio meu e uma ou duas semanas, em menos de duas semanas, nós já estávamos assim. Sabe, assim? Tava, assim, apegado, se gostando, foi uma coisa de louco. E aí quando a gente se, foi se conhecendo melhor e eu já morava com essa outra mulher. Mas aí eu optei...

Entrevistador: Como que ficou a sua situação com essa mulher?

Dirceu: Nossa, ficou horrível, depois de um tempo, entendeu? Porque nós escondemos isso, escondemos e fomos escondendo. Mas aí teve uma hora que não teve mais jeito e aí a gente teve que abrir o jogo. E ela assim mesmo falou que me aceitava, mesmo com ele. Propôs de vivermos os três juntos porque ela não queria me perder. Eu morava com ela e era amante do Emílio, depois eu fui morar com o Emílio e ser amante dela. Até ela se desligar. E, nesse vai e vem, ela engravidou, aí eu tenho essa outra filha minha mas eu não sabia o que eu queria mais. Eu tava com a cabeça super fraca. Eu não sabia se eu queria viver com uma mulher. Não sabia mais quem eu era, não sabia, passei muito mal, procurei até uma psicóloga. Não sabia o que eu queria.

Entrevistador: Quanto tempo durou essa fase que você estava com ambos?

Dirceu: Uns quatro anos, foi muito tempo, foi tanto que minha menina hoje tá adolescente. Tou com ele há muitos anos.

Entrevistador: E se você fosse me contar o que é o melhor da relação de vocês, o que você destacaria como as melhores coisas da relação?

Dirceu: Eu acho que o que eu mais destacaria dessa relação do homossexual... é que não são todos iguais, como os casais heteros também não são todos iguais, eu acho que é mais, 
assim, o respeito que um dá pro outro, essa confiança, nós trabalhamos toda vida juntos, entendeu? Onde um tá, o outro está, nunca vê um sozinho, sempre estamos juntos, saímos do Brasil, moramos na Europa e junto, sempre junto. Eu acho que é isso que é o mais importante, é o respeito mesmo de um e outro, fidelidade, essas coisas. Então nisso é mais um alicerce, uma firmeza, você entendeu? Sem aquela desconfiança, e as mulheres sempre têm desconfiança de mim. Eu nunca tive tanta, mas elas tinham, de mulheres também, né? Não era de homem, de mulheres, achavam que sempre tava aprontando. Mulher é assim, essas coisas.

Entrevistador: E, se você fosse apontar o que acha que é mais difícil na relação, o que você apontaria?

Dirceu: (risos) É um ser humano aturar o outro porque todo mundo tem defeito. Pra você viver com uma pessoa, eu acho que você tem que primeiro se amar, entendeu? Se respeitar, se gostar muito, pra depois conviver e gostar da outra pessoa. Porque uma relação a duas pessoas hoje é muito difícil. Você quer uma coisa, eu quero outra mas às vezes eu tenho que abrir mão do que eu tô fazendo pra querer o que você quer e nisso não é todo mundo que abre mão, não. As pessoas... tipo agora, né? Eu tenho, eu fui casado, tive filhos, eu tava assim, não sou carente de filhos porque eu amo meus filhos. Eu tenho uma relação muito boa, os dois formaram comigo, trabalham, né? Uma trabalha já e a outra só que vive com a mãe porque ela é mais novinha. Mas é como eu tou te falando, então eu já não tinha mais essa precisão de ter um filho. Eu não precisava disso de jeito nenhum, nada espontâneo mas quem eu vivo estava carente de um filho, carente de ser chamado de pai. Eu vi o lado dele e falei: pode fazer o que você quiser que eu tô do seu lado, por que? Porque ele nunca teve filho mas eu já tive. Pra mim não precisava de filho, já tava muito feliz, ele sempre falava, mas ele tinha os meus que eram pequenos viviam comigo. Então ele tinha eles, a mim, então... mas ele não... ele ouvia eles falando: pai, pai! Ele queria que falassem pai pra ele mas não falavam porque tio e pai, né? E ele sentia que ele era carente pra ter um filho que chamasse pai. Aí nós fomos morar numa chácara e nós ficamos sozinhos, ele sentiu que ele queria um filho, queria adotar, aí eu falei: adota um, né? Ou até dois. Adotou quatro e é isso (risos), na falta de um...

Entrevistador: E eu acho que de alguma forma você já respondeu a próxima. Eu ia te perguntar se você podia me contar algum fato que mostra como é que é a relação de vocês. Mas acho que você já contou.

Dirceu: É.

Entrevistador: Então vamos em frente, como era a sua família de origem?

Dirceu: Então, eu sou de uma família de espanhol com italiano, né? São assim bem, bem grosso e meu pai não é gay, não tem parente gay e que eu tenha ouvido falar não tem ninguém que seja gay, entendeu? Todas irmãs do meu pai, os irmãos da minha mãe, tanto os irmãos e as irmãs... Todos são casados, têm filhos, não tem ninguém gay e minhas... eu tenho quatro irmãs, todas são bem casadas, eles nunca aceitaram minha vida, minha opção sexual, minha vida sexual. Depois, por eu ter sido casado, tido meus filhos... então meu pai, minhas irmãs nunca aceitaram, não por ser o Emílio, por ser um outro homem. Porque eu teria que ter uma mulher, não um homem, entendeu? Então minha família sempre teve preconceito sobre isso, nunca aceitou mas eu demorei pra contar pra eles, depois de sete, oito anos... já vivia com Emílio longe da cidade, por isso que a gente saiu da cidade, aí eu nunca contei. Ele era sócio, acabou. Tava junto mas era meu sócio, acabou e meus filhos também. Eu sempre... os meus filhos... eu sempre contei a verdade porque eles sempre me respeitaram muito, tem uma educação muito boa, então isso é importante. Mas meus pais eram assim, não aceitavam. Minha mãe morreu já tava com uns sete anos e aí que eu fui contar pro meu 
pai. Na morte, depois que minha mãe morreu, que eu achei que eu tinha que contar, não agüentava mais aquele peso. Depois que minha mãe morreu, dali a uma semana, duas, eu cheguei no meu pai e falei que eu tinha que contar uma coisa pra ele muito séria. Cheguei e contei que eu vivia com o Emílio, que ele não era só sócio, que eu vivia com ele, que eu amava ele e se meu pai quisesse me amar assim mesmo ou não... eu sei que depois disso podia mudar e lá no quarto ele me abraçou e chorou... e falou: nossa filho, eu te amo, eu sei que você mais agora precisa de mim. E me deu todo o amor do mundo, entendeu? Mas ele, no fundo, não deixou de ter um preconceito... (risos) que eu já ouvi várias vezes depois dele coisas que eu não comento com o Emílio, que eu acho que ele tem, que ele gosta muito do meu pai, meu pai gosta dele e não é por ele, é por ser um homem, tá entendendo o negócio? Que ele gosta muito dele, do meu pai mas que ele é uma pessoa maravilhosa, mas é por eu viver com um homem. Então, no fundo, eu sei que o meu pai não aceita, que ele chega em mim às vezes e fala: você deveria ter uma mulher, né filho? Sempre, dessa última vez, agora, pelo dia de ano novo.

\section{Entrevistador: Até hoje?}

Dirceu: Você deveria ter uma mulher, né filho? Não é o caminho certo, né? Mas tudo bem, tudo bem, mas só que depois de ado... de adotar essas crianças, faz um ano e pouco, mudou muito pra melhor, né? Minha família, minhas irmãs não gostavam dele, nem ia na casa do pai quando ele tava, hoje elas vão, hoje elas amam e elas dizem assim que o que nós dois fizemos, nós já ganhamos o caminho do céu, já tem o pedacinho reservado (risos). E elas se emocionaram, choraram muito quando a gente chegou e contou que nós tínhamos adotado e que elas diziam assim que jamais achavam que a gente tinha, assim, essa capacidade, entendeu? De ir tão longe, então isso também uniu mais, então hoje, nossa, elas gostam muito mais dele e... entendeu? Ele entrou melhor na família nossa depois dessa ação que nós fizemos, ninguém imaginou que ia ser assim. Não foi feito por isso, mas melhorou, entendeu?

Entrevistador:E me conta uma coisa, vocês estão casados há quantos anos?

\section{Dirceu: Dezessete...}

Entrevistador: E como é que foi a decisão de vocês ficarem juntos?

Dirceu: Então, ele tava trabalhando pra mim, ele virou sócio e depois disso a gente... Ele falou assim: onde você mora? Eu falei: eu moro em S. Aí ele falou: nossa! Então nós éramos vizinhos mas não sabíamos. E era vizinho e tão pertinho. Aí ele falou assim: ah, vamos sair hoje? E desse dia pra cá a gente... nossa... sentimos uma loucura mesmo e acabamos indo morar juntos. Foi uma decisão de louco... que ninguém segurou... não sabia o que tava acontecendo, eu só me separei, né? Que eu morava com a outra menina. Mas eu só falei que não dá mais e que ia morar com ele, cheguei e contei a verdade porque foi dentro de um mês, rapidinho, porque ela descobriu mesmo também. E eu disse que eu falava: eu não sei, eu amo ele. Nossa, você ama ele? Eu falei: amo, eu falei na frente dela, bem sincero.

Entrevistador: E você tem acompanhado toda a discussão que acontece sobre adoção por casais homossexuais e a discussão sobre a união estável? O que você pensa a respeito?

Dirceu: Eu tenho acompanhado mas, você quer saber? Cada um tem uma... eu tenho... eu ouço falar tanto, assim, eu acho assim, eu acho que ser humano não depende de união, não depende de bens um do outro. Eu acho que nada depende de nada, eu acho que o mundo inteiro... o mundo tá ali, o mundo é teu, o mundo é meu, você faz a sua parte, eu faço a minha parte, você tem a sua parte, eu tenho a minha parte, você é você, eu sou eu, você me entendeu? Se você precisar, eu tô aqui. Se eu precisar, você tá aí. Nós temos que ser, eu acho 
assim, numa harmonia total, entende? O Emílio mesmo, nossas coisas, ele tem as dele, eu tenho as minhas, embora seja tudo junto é isso que eu tô aqui dizendo. O que o papel manda? Um casal se casa no papel bonitinho, amanhã tá separando. Eu vivo há dezessete anos com ele, nós não somos casados em papel, tamos juntos até hoje e além de tudo isso conseguimos alguma coisa, essas coisas que a gente conseguiu, alguns bens, ele tem metade no nome dele, metade tá no meu e aí temos os filhos. Morrendo, vai ficar pra eles, se não vamos ter que trabalhar pra conseguir. O mundo tá aí inteiro e nós temos que lutar pelos nossos ideais, entendeu? Pelo que nós queremos. Eu acho que a maior herança de uma criança é a educação, é ensinar eles a trabalhar, é pôr eles no caminho, que o único caminho, é o caminho certo e acabou. Não tem dinheiro, não tem nada que pague, eu acho que primeiro mesmo é uma educação que eles tem que ter, entendeu? Saber viver, conseguir as coisas.

Entrevistador: Ok, e como foi o caminho para vocês conseguirem adotar?

Dirceu: Não foi um caminho difícil... difícil... porque na época que o Emílio queria adotar uma criança ou duas... nós saímos de abrigo em abrigo... abrigo em abrigo... conhecendo, levando alguma coisa, sabe assim? Sempre a gente ajudou, pegava de cliente, sempre ajudou, os abrigos, pegava no final de semana e o que nós... o que ele queria não estava disponível, eram dois irmãozinhos, não estava disponível. Porque uma criança pra estar disponível ela precisa estar destituída de pai e mãe, entendeu? Ela tá indo prum caminho de adoção e nós não escolhemos, nós fomos escolhidos pelas crianças, então foi um processo mais fácil mas do mesmo jeitinho de outros processos. Às vezes até com pouco mais de dificuldade porque foram quatro, entendeu? Mas não tivemos dificuldade porque eu acho que dificuldade você já sabe quando vai ter. É quando você não é... opta a fazer o que você vai fazer e se você tá pronto pra fazer o que vai fazer não tem porque você ter medo e nem achar que não vai dar certo, você entendeu? Você já tem a certeza na sua cabeça, eles são meus porque já deu certo, você sabe, você sabe, você sabe se eu tô te tratando bem, se eu tô te dando carinho, desde que você é adotado e adota não tem porque falar que tá errado, fica certo.

Entrevistador: E me conta o seguinte... qual são os aspectos dessa discussão sobre adoção e sobre união que mais te chamam a atenção?

Dirceu: Eu acho assim que o que mais me chamou atenção, eu acho assim, eu acho assim uma falta de... de, eu nem sei explicar... uma falta de moral, uma falta de uma coisa assim que eu nem sei explicar o que é, uma falta de consciência... sei lá, entendeu? Eu não sei explicar... é... das autoridades essa... uma criança tem um nome de um pai... eles acham que só é dado pra um... cê tá sabendo disso, né? Não é pra dois... tem um nome, tem dois pais na vida real, tem dois pais e ninguém vai tirar, tem dois que vivem junto porque os pais ali, a família se vira do amor, entendeu? Da convivência vem o amor, então a criança tem dois pais e esses dois pais, se uma criança... eu acho que ela deveria ter o nome também dos dois pais... porque eles acham que elas só tem direito do nome de um. Agora que defesa essa criança tem? Com um pai? Eu acho que ela teria muito mais defesa com dois pais porque um pai pode morrer... todos nós somos assim. Hoje tá vivo, amanhã tá morto. Um pai pode morrer... sobrou um... essa é a primeira hipótese, segunda hipótese:. você tem, você tem o... o pai ou a mãe... ou os dois pais... em vez de ter um... hoje uma criança tá... vamos supor, na escola... quebrou, caiu... e o outro... você tinha que levar no medico... porque ele não tá bom... aí você tinha que virar o que? Dois... não é verdade? Tem que socorrer... mas um deles não é pai mesmo... então eu acho, assim, que essas... que essa lei... eu acho... eu abomino... eu acho que eles deveriam ter o nome dos dois sem pensar... olha... tapar os olhos desses juizes... desse povo grande aí que eu não sei quem é... porque não existe... você concorda? Você tá entendendo o que eu tô dizendo... não pode... isso não existe. É a pior das coisa que tem é isso aí... embora a gente tem consciência, isso é pra quem tem consciência... um homem... o outro é dono dos filhos? Mas não é, por lei, não é... se tá só no teu nome você 
que é o pai, meu nome não tá na certidão de nascimento nova, eu posso até fazer isso aqui, ó. Dar as minhas costas e ir embora... e aí... e aí? Vai da minha consciência... não te conheço, não quero nem saber de vocês.... você não é pai da filha dele, você me entendeu? O que eu tô explicando? Depende da pessoa, do caráter, eu jamais faria isso mas eu tô falando, assim, uma situação, que pode acontecer.

Entrevistador: Pode.

Dirceu: A pessoa pode dizer assim: ah, não quero nem saber, tava no nome dele, não tava no meu... que responsabilidade eu tenho? Você entendeu? Eu acho assim... essa situação é a coisa mais... nesse processo todinho... jurídico... e não é tanto dar o nome pra ter uma herança, é dar o nome pra encaminhar, pra responsabilidade a dois, pra família ficar com mais segurança, pros filhos terem mais segurança... disso naquilo... naquilo... naquilo... se um tá com um problema lá, na delegacia, foi preso, pegou uma lata de leite condensado (risos) no mercado, o pai vai pra lá mas o outro tá no hospital. O outro pai é responsável no local, porque, na delegacia, só é responsável quem é no papel, você entendeu? Aí os dois, eu sou o responsável, depende da pessoa porque o outro está na escola ou no médico com o outro... para o bem estar da criança, é o que eu tô te falando, não é a herança, não é por nada disso, não é por nome de herança porque herança é o que eu te falei, é a educação, é colocar eles... é dar uma mão, é ensinar a pescar e não dar os peixes. É isso.

Entrevistador: E o que é família pra você?

Direu: Eu acho que família é aquela... é a... é a coisa... é uma coisa assim... é a coisa mais linda, entendeu? Embora eu, quando eu me separei, fiquei sem minha ex-mulher mas fiquei com meus filhos porque eles ficaram morando comigo então eu acho que a família é aquele amor, é aquela união, você entendeu? Tem aquelas partes, é um compreender o outro, é muito dialogo... é... é isso aí, entendeu? Eu acho que o amor é a base total, o amor é a base, assim, a primeira, o primeiro alicerce da família vem o amor, depois a gente vai o resto a gente dá jeito pra tudo, pra isso, pra aquilo, pra aquilo...

\section{Entrevistador: O resto resolve...}

Dirceu: Resolve tudo... mas, primeiro, eu acho que é o amor... a família... tem que ter muito amor, muita compreensão e muito dialogo...

Entrevistador: E você teve algum critério quando você adotou seus filhos?

Dirceu: Não, não, nunca pensei: isso aqui vai ser importante. Eu só sei te dizer uma coisa, pode ter certeza, depois que nós adotamos essas crianças a nossa vida mudou, mudou pra melhor, mudou totalmente, mudou, mudou muito, mudou muito, até eu e o Emílio, você entendeu? Acho que ele precisava mesmo ter um filho porque agora eu acho, mesmo ele amando meus filhos, porque ele ama, porque meus filhos desde pequeno moraram com a gente... Ele defende meus filhos, tudo... então eu acho que, mesmo ele amando meus filhos... mas ele agora se sente... ouvir: pai, né? Me leva no dentista, ele vai em reuniões, eu deixei tudo pra ele fazer, porque eu já fiz isso, e eu deixei tudo para ele, ele que vai... ele que vai em tudo. Mas ele tá sendo aquele pai, assim, exemplar... entendeu? E ele via... ele defende, vai na escola, ele é... ele é membro, ele é presidente do não sei o quê da merenda escolar... ele...ele... ele participa de tudo. Todos os dias ele pega caderno, todos os dias ele corrige, ajuda, todos os dias escova os dentes das criança, quatro, cinco vezes no dia. Ele mudou, acabou, agora não tem tempo pra nada, entendeu? Então foi só pra melhor... então é isso que eu falo: por que um homem não pode ter um filho adotado com outro homem? Ou uma mulher com outra mulher? Por que não? Se tá fazendo bem pro ego da pessoa e dos outros, entendeu? Eu acho isso. 
Entrevistador: Bom, minhas perguntas acabaram... tem alguma coisa a mais que você acha que vale a pena contar nessa pesquisa que eu não tenha te perguntado?

Dirceu: Não... eu acho que não... acho que nós falamos tudo... né?

E: Então muito obrigado por me receber. 


\section{9 - ANDRÉ}

André: entrevistado.

Maurício: companheiro de André.

Entrevistador: Então, André, eu queria que você começasse me contando um pouco da tua história com seu parceiro, e que começasse por onde quisesse e fizesse os destaques que você quisesse sobre essa história.

André: Nós nos conhecemos a um tempo maior, assim, antes da gente ficar junto mesmo, mas, bem... de vista, não tínhamos muito contato, tínhamos alguns amigos em comum e muita gente querendo que a gente não se encontrasse, uns amigos assim meio, meio, não gostariam, não queriam que a gente ficasse junto em nenhum momento.

Entrevistador: Por conta do quê, você sabe?

André: É, não sei, eu, talvez ou ciúme... não sei exatamente. Aí um dia a gente acabou ficando, ficando junto e... foi muito rápido, assim... a gente... é... ficou junto dia primeiro de janeiro, no aniversário dele e... em vinte dias já estávamos morando junto, já tínhamos construído tudo e no começo foi difícil, não... pela nossa relação, embora a gente não se conhecia muito, mas sim porque a gente não tinha nada, era um colchão e só, numa quitinete.

Entrevistador: Hum

André: E isso é muito prazeroso, porque a gente comprou tudo o que a gente tem hoje, é... foi comprado junto, foi conquistado junto, ao contrário de uma família hetero, quando se casa ou quando se une, é... ganha tudo, né?

\section{Entrevistador: Hum.}

André: Faz a festa de casamento, geladeira, fogão, cama, tudo é ganhado. A gente teve que conquistar tudo aos poucos e ainda tamos conquistando, ainda. E a gente tá junto há quatro anos, completados agora dia X ... e é uma relação bem assim... a gente é parceiro em tudo, a gente convive todos os dias juntos, a gente não consegue ficar longe um do outro em nenhum momento. Já trabalhou junto, ficamos vinte e quatro horas junto durante meses, só que o trabalho não deu muito certo...

Entrevistador: Hum. E como... como foi trabalhar juntos?

André: A gente é, é... na verdade eu era até auxiliar dele, então a gente trabalhava um... do lado do outro no computador e não era aqui na cidade.

\section{Entrevistador: Hum.}

André: Era numa cidade próxima, então a gente ia... é, ficava num hotel, ia de segunda-feira, ficava no hotel junto, então era vinte e quatro horas mesmo junto, desde o horário do almoço ao... o momento todo, era muito bom, a gente não briga, a gente não costuma brigar muito, mas lá, assim, o trabalho... a gente não tinha discussão nem... questão de trabalho nem... em algum outro aspecto, era um trabalho muito bom. É, mais ou menos isso assim, minha família já, na época não sabia... de mim e eu apresentei o Maurício já falando, já declarando que ele era meu parceiro, pra minha família inteira, então não deixei ninguém abrir brecha pra me criticar ou ter alguma desconfiança. 
Entrevistador: Hum.

André: Eu achei desnecessário porque eu vi que ele era realmente a pessoa que eu queria pra mim, então eu deixei tudo aberto.

Entrevistador: E como é que tua família reagiu, como é que foi da parte deles?

André: Eu acredito que minha mãe até já desconfiou em alguns momentos, mas nunca tinha certeza e eu tentava fazer de tudo pra não descobrir, assim, arranjava namoradas, tinha algumas namoradas, é... enganava muita menina, eu também me enganava mais ainda, que eu achava que eu era bissexual, ou até mesmo como... eu tinha falado antes, sem-vergonha, que não, que não era uma coisa certa etc. ... Então, minha mãe aceitou bem, minha mãe mora sozinha, em D, então ela aceitou bem, porque ela viu que a gente tava bem, é... que eu tava tentando buscar um outro... outro lado da vida, tava tentando crescer mais, ela viu, é... em mim uma pessoa melhor.

Entrevistador: Hum.

André: E se, com certeza se, se qualquer pessoa perguntar pra ela: você queria que seu filho fosse hetero hoje? Ela ia falar não, eu gosto do... Maurício, eu gosto do... do André, eu quero que os dois fiquem junto. Porque... ela me fala isso sempre.

Entrevistador: U-hum.

André: Os outros familiares não comentam, eles sabem, mas não comentam, respeitam muito, mas não comentam. Eu nem cheguei a falar diretamente pra nenhum deles, mas é, onde eu tô, quando eu vô pra D, eu vô ao lado do Maurício.

Entrevistador: Você tem irmãos...

André: Tenho uma irmã pouco mais velha.

Entrevistador: Hum.

André: Casada, tem dois filhos, ela também sabe, aliás a família inteira sabe, respeita bastante, trata o Má como um outro irmão.

Entrevistador: Hum.

André: Muito legal.

Entrevistador: E, me conta o seguinte, o que você me diria que é o melhor na relação de vocês?

André: A... cumplicidade.

Entrevistador: Hum?

André: A cumplicidade que a gente tem, o respeito..., é, o carinho, eu acho que tudo, o... o... a... a consideração e admiração que eu tenho por ele acho que é o ponto mais forte.

Entrevistador: E por quê? Me conta a respeito disso. 
André: Ah... ele é uma pessoa inteligente, é... uma pessoa carinhosa, determinada, ... me faz muito bem, me entende... ah... não tem muito o que falar assim, acho que, é, eu acredito que existe alma gêmea, ou algu... alguma coisa assim porque foi muito, muito rápido e não tem uma explicação.

Entrevistador: U-hum.

André: O que aconteceu entre a gente.

Entrevistador: Hum.

André: Foi muito bom.

Entrevistador: E o que você acha que é o mais difícil na relação de vocês? E porquê que seria o mais difícil?

André: $\mathrm{O}$ mais difícil é... acho que é... é a vida mais social, parte de... trabalho, às vezes a gente tem que, não mentir, mas omitir, pra não sofrer preconceito explícito ou... é omitir ou... é, não ser totalmente verdadeiro com as pessoas, fugir de determinados assuntos, pra não ter preconceitos, pra não ter que sofrer nenhum preconceito ou evitá-los. É, eu nunca vou falar que não sou gay pra ninguém que me pergunta: você é homossexual? Vou falar: sou. Mas é... até chegar a esse ponto acho que... é, muito, muito diferente, assim, a pessoa quando pergunta isso é porque tem um grau de intimidade maior, às vezes eu até procuro não ter esse grau de intimidade pra não é... pra não atrapalhar no trabalho.

Entrevistador: Hum.

André: Eu acho que tem pessoas que misturam muito.

Entrevistador: Tá, tá bom.

André: Eu vejo isso bastante, principalmente aqui em K.

Entrevistador: Hum.

André: Por aí.

Entrevistador: No trabalho de vocês dois?

André: Meu trabalho é mais sossegado, o do Má é mais complicado, por que é uma empresa um pouco maior, tem mais... é... eu trabalho também com W, nós dois trabalhamos, e as pessoas que trabalham com a gente são muito turrão, com cabeça muito fechada, não entendem, não sabem o que é isso, é, não acreditam, não acreditam que exista, tem a imagem de gay... aquele homem que se veste de mulher e fica na esquina fazendo ponto, então, então, até explicar, acho que não convém a mim ficar explicando a todo mundo.

Entrevistador: Tá.

André: ...Também sô normal, não preciso ficar me justificando a tudo que faço.

Entrevistador: Hum.

André: Pras pessoas... que eu convivo. 
Entrevistador: E me conta o seguinte, tem alguma situação que você poderia me contar que melhor mostra como que é a relação de vocês, que é exemplar, da forma como vocês se relacionam?

André: É... hum... a gente tá junto em todo, todo momento. É... acho que o que eu mais que eu sinto dizer é que isso, sim, é que eu não consigo dormir se ele não tiver do meu lado na cama.

Entrevistador: Hum.

André: Eu não tenho sono, eu não durmo. Então, acho que... tá por aí. Não consigo ficar... é... dormir sem ele do meu lado, eu não consigo me empolgar pra cozinhar ou até mesmo... é... é complicado (fala rindo), mas acho por aí, é, ele significa muito pra mim, eu acho que esse é... essa nossa história... essa agilidade que foi nosso relacionamento, já mostra o quanto que foi importante, o quanto ele simboliza pra mim.

Entrevistador: E como é que era tua família de origem, André? O que você pode me contar dela?

André: Ah... meu pai faleceu quando eu tinha 17 anos.

Entrevistador: Hum.

André: É... e... meu pai e minha mãe já era di... divor... já não tavam mais juntos, já não tavam mais casados. É, minha irmã casou no final da adolescência, é, teve um filho jovem e... tem dois filhinhos hoje, duas sobrinhas, uma de... completou, vai completar dois anos... Minha mãe, ela é... ela é muito nova também, então ela consegue me entender bastante, muito. Ela tem problemas com depressão, então ela é uma pessoa muito carente, então é ela é... se apegou muito a mim.

Entrevistador: Hum.

André: Então, quando minha irmã casou é... eu saí de casa com 18 anos, então foi muito chocante quando eu quis sair de casa, minha mãe sofreu muito, mas eu precisava sair de casa.

Entrevistador: Hum.

André: Pra ela viver mais, porque ela dependia de mim pra tudo.

Entrevistador: Hum.

André: Ela... ela... ela dependia de mim... pra... pra tudo assim, em casa ela... eu vou fazer a comida dela, eu cuidava dela, então eu mudei os papéis em casa, eu era o pai dela em casa e ela... era quase minha filha.

Entrevistador: U-hum.

André: E quando eu saí de casa, eu vi que ela melhorou muito, a depressão dela praticamente foi embora. Ela casou, ela tá, tá assim... tá se relacionando com uma outra pessoa, com um cara, muito bacana.

Entrevistador: Hum. 
André: Eu adoro ele e ele me respeita bastante, aceitou eu e o Má de boa, a gente vai em casa e trata ele com muito respeito, por que ele faz muito bem pra minha mãe, os meus os meus avós são pessoas muito simples, mas eles... são pessoas modernas, eles entendem é... o, que eu sinto, o que acontece com... comigo, eles sempre me apoiaram em tudo o que fiz. É, assim... quando eu morava em $\mathrm{D}$, eu até tinha muita briga com minha mãe, porque eu cuidava muito dela e eu via que ela não fazia nada se eu não determinasse.

Entrevistador: Hum.

André: E a gente tinha muito atrito e hoje eu vejo que a nossa convivência tá muito melhor.

Entrevistador: Hum

André: É, minha mãe sempre... liga, eu ligo pra ela e a gente conversa sobre tudo, inclusive sobre a minha ho... homossexualidade, é... sobre a vida dela. Então, eu tou... conheci muito mais minha mãe a partir do momento que eu também me abri pra ela.

Entrevistador: Hum.

André: E assim ficou mais fácil. Minha família é... é mu, muito boa, minha família, eu gosto muito de minha família, eu acho que minha família é um exemplo pra mim.

Entrevistador: Hum.

André: Tanto a relação do meu pai e da minha mãe, mesmo eles se separando, eu não tive, não tendo uma relação contínua assim, até... é, até meu pai falecer mas eu admiro muito a vida e que eles fizeram pra me criar assim, foi muito bacana, é, eles fizeram o que eles puderam. Eles casaram muitos novos por causa de uma gravidez, quando eu nasci minha mãe era moça ainda, meu pai era um rapaz, então era praticamente dois adolescentes, então eles erraram muito...

Entrevistador: Hum.

André: E acertaram muito. Então... eles, às vezes minha mãe se culpa, por alguma coisa que ela fez com, comigo quando eu era criança, dela ter me batido, dela ter me falado alguma coisa, mas eu vejo que era, que era porque ela era muito imatura, e é...

Entrevistador: U-hum.

André: E... é, deve ser muito difícil criar uma, duas crianças, né?

Entrevistador: É, deve ser...

André: Deve ser muito complicado sim, embora ela teve o apoio da família inteira também.

Entrevistador: Teu pai faleceu quando?

André: Meu pai faleceu quando eu tava no fim da adolescência, ele... morava em B ... ele tava, começando a fazer faculdade e ele, ele morreu... então ele tava... preparando a vida dele, um, ele tinha construído... o que ele podia construir.

Entrevistador: Hum. 
André: E tava tentando crescer. Mas ele, quando ele nasceu ele teve que fazer uma operação, uma operação no coração, e eu não sei direito o que é a doença que ele teve no coração. E ele tinha que operar um dia.

Entrevistador: U-hum.

André: ...só que os, poderia ser daqui a dez anos, ou poderia ser hoje. Então ele optou. Tou de férias e vou operar agora, quando eu voltar já consigo trabalhar de novo e voltar à faculdade, começar a faculdade tranqüilo. Só que ele não resistiu na segunda cirurgia, ... aí... porque ele acabou falecendo.

Entrevistador: U-hum.

André: Foi assim, meu pai não ficou sabendo da minha homo, homossexualidade, porque eu também não sabia na época... é, sabia que eu não era normal, que eu não era igual a todo mundo, mas não sabia exatamente o quê eu era. E nossa convivência, assim, comigo e com meu pai sempre foi meio distante, até o, os meus quinze anos, quando a gente ficou próximo, assim, a gente ficou amigos mesmo, a gente conversava diariamente. Ele faleceu...

Entrevistador: Hum.

André: E eu me senti mal na época, eu me senti culpado, me senti, eu pensava que... meu pai... morreu sem eu falar "eu... eu te amo" pra ele, então, foi muito difícil pra mim na época.

Entrevistador: U-hum.

André: Mas já passou e eu, quando eu busquei o Espiritismo, minha religião hoje, foi pra entender é... exatamente o que se passava comigo.

Entrevistador: U-hum.

André: Foi muito interessante também, acho legal.

Entrevistador: E como é que foi a decisão de vocês ficarem juntos?

André: Ah, eu acho que não teve uma decisão, foi, foi bem tudo no impulso, assim, tudo no sup... no, no impulso assim, no supetão.

Entrevistador: Hum.

André: Eu, eu dividia apartamento aqui em $\mathrm{K}$ com um colega e eu ia mudar pra uma, prum, prum outro lugar. E eu tava procurando na... a casa e ele tava tava me ajudando. Aí eu falei pra ele: ah, você não quer morar comigo? Eu num quero morar sozinho, eu ti... tinha que arrumar alguém pra dividir porque vai ficar apertado e tal, você não quer morar comigo? Ele fala: ah, acho que não. Vou esperar um tempo, tal, vou falar com minha mãe e vou aos poucos. Só que, a partir do momento que a gente entrou no apartamento, a gente começou a morar junto. Ele já buscou as coisas dele... não teve o tempo, esse tempo que, que ele queria na época. Ah, vou pegar, deixar um tempo, venho, fico uns dias, aí volto, só pra minha mãe se acostumar. Só que acabou sendo bem mais rápido, assim, no primeiro dia a gente já tava morando junto, quando conseguimos a casa já começamos a morar juntos.

Entrevistador: Era aqui já?

André: Não era um, uma outra qui, uma quitinete no centro. 
Entrevistador: Tá, tá bom. E, me conta o seguinte, é ... Você já me contou um pouco como que tua família de origem se relaciona com teu parceiro, e eu ia te pedir pra você me contar alguma situação à título de exemplo, de como é que é essa relação, o que você acha que poderia me contar como uma situação exemplar de como ela... como ela é.

André: Hum... minha mãe, ela... tipo assim, meu quarto tinha uma cama de solteiro, né? Meu quarto na casa da minha mãe, ela comprou uma bicama.

Entrevistador: Hum.

André: De casal, que fica mais fácil pra ele se acomodar.

Entrevistador: Hum.

André: Um exemplo que... que ela quer ver a gente bem, quer que a gente vá mas, mais pra lá, nós dois junto. Minha mãe convive muito bem com o Má, ela fala... bastante com ele por telefone, ela liga pra ele pra conversar no aniversário dele... ela me pergunta o que eu vou dar no dia dos namorados.

Entrevistador: Hum

André: No dia... que a gente faz... aniversário de relacionamento, ela pergunta o que eu vou dar de presente... ... ela pediu uma foto do Má pra por no mural que tem lá em casa, que só tem foto da família, ela quer por foto do Má também.

Entrevistador: Hum.

André: Ahn, meu sobrinho, chama, minha sobrinha, né? Meus sobrinhos chamam, chamam o Má de tio.

Entrevistador: Hum.

André: Ahn... mais ou menos assim. É...

Entrevistador: Acho que tem várias situações exemplares aí

André: É, minha sobrinha, ela tem seis anos, ela chama o Má de tio e... é lógico que ela não entende, né? Ela acostumou a chamar assim, mas é claro que minha irmã... influencia, né?

Entrevistador: U-hum.

André: Tio André, tio Má, aí os... os sobrinhos do Má também. Às vezes, eles são maiores, né? Então eles já entendem tudo, aí às vezes eles soltam um: tio André...

Entrevistador: Hum.

André: É... eles são mais velhos então eles tem um pouco mais... e eles se comportam mais assim, retos, mais diretos.

Entrevistador: E me conta uma coisa, você tem acompanhado o debate sobre a adoção por casais gays? 
André: Eu tenho visto é... algumas coisas, eu não me aprofundei muito é... pra ver documentação, tal, porque a gente ainda não tá preparado financeiramente pra adotar uma criança.

\section{Entrevistador: Hum.}

André: Então, eu falei: nem vou procurar senão vou ficar empolgado, eu vou querer adotar hoje e... Mas, assim, a gente, eu acompanhei um pouco pela televisão, alguns casos, algumas reportagens que teve no Globo Repórter, se não me engano, sobre casos de... de adoção, até mesmo alguns casos é... que a justiça tá dando mais visão como o da Cássia Eller, que querem adotar uma criança ou que tem um filho. É, eu acho viável, é... acho até necessário, porque meu sonho é ter um filho e não, não só porque sou gay que eu não tenho, eu não vou poder ser pai.

\section{Entrevistador: Hum.}

André: Então eu acho que posso dar uma educação pro meu filho, posso educar uma criança perfeitamente... eu, com certeza ele vai ter o amor e o respeito possível, ele vai entender tudo, vou ensinar tudo o que eu puder a respeito disso, ele vai ser uma criança com certeza sem preconceito e sem... é... como fala, sem vergonha dos pais.

Entrevistador: Hum.

André: Ele não vai ter vergonha dos pais em nenhum momento.

Entrevistador: Hum.

André: É... assim, eu acho interessante que a lei hoje tá dando prioridade a isso, a adoção, porque tem tantas crianças na rua, tanta, é... tanta gente precisando desse apoio, e a gente não podia adotar simplesmente pelo fato da gente, de sermos homossexuais.

Entrevistador: U-hum.

André: Eu acho isso muito válido.

Entrevistador: Tá.

André: Até mesmo, num assunto que não, não tem nada a vê... é, é de doar sangue. Se você é homossexual, eles proíbem, é, todos, todos esses pequenos detalhes mostram a ignorância, um poço até mesmo é de alguns aspecto da medicina, de governo. Eu sou homossexual, não quer dizer que eu tenho HIV.

\section{Entrevistador: Hum.}

André: Um hetero pode ir lá doar tranquilamente e ter HIV. Então acho que tem muita coisa ainda, pessoas que estudam, que sabem e tem essa visão muito ultrapassada.

Entrevistador: U-hum.

André: Então, é por aí.

Entrevistador: Tá, tá bom. E... bom, acho que você começou a me contar já, eu ia perguntar, se tem algum aspecto desse debate da adoção que te chama mais atenção, tem algum que você queira destacar, especialmente, e porque? 
André: Hum... acho que é o fato de você poder dar amor a uma criança, independente do seu sexo, ou da sua religião, da sua cor, ou qualquer outra coisa... é valido.

Entrevistador: Hum.

André: O amor, que você, que você pode dá a qualquer pessoa é válido.

Entrevistador: Hum.

André: Acho que é, é isso.

Entrevistador: E o quê que é a família pra você?

André: É o meu alicerce.

Entrevistador: Hum.

André: O que eu sô hoje é graças a minha família. É, tudo o que eu sei, a respeito de relacionamento, de relacionamento com as pessoas, é... no geral, de educação, tudo, eu agradeço à minha família.

Entrevistador: Hum.

André: Tanto, não só minha mãe e meu pai, como meus avós, meus tios, minha família no contexto em geral, se sempre tudo o que eu fiz eles me apoiaram, eu acho isso muito interessante, muito bom.

Entrevistador: Hum.

André: Foi muito legal.

Entrevistador: Bom, você não tem um filho adotivo. Mas eu ia perguntar o seguinte, você teria critérios específicos pra adotar um filho, critérios de escolha, né? Aspectos que você gostaria que a criança tivesse pra adotá-la?

André: Hum... não. Assim, eu acho, eu acho bonitinho ver criança japonesa assim, eu acho muito bonitinho, eu acho impossível adotar uma criança japonesa, não existe criança pra adotar japonesa, mas eu quero adotar uma menina negra.

Entrevistador: Hum.

André: Uma menininha negra e um menininho... tanto faz, acho que, mais a menininha negra que eu acho bonitinho, menininha negra e tal... mas, tanto faz, na realidade a gente fala isso, brinca que ia ter um filhinho japonês e uma menininha negra, a gente fala, mas é, na verdade, acho que se a gente tiver oportunidade de adotar... vai ser a criança que tiver, assim, na nossa, na nossa mão, que a gente puder olhar pro rostinho dela, acho que vai ser aquela, num, num, independente da cor dela, se tiver algum problema ou não, vai ser a criança que a gente olhar e ver, sentir, é... que abraçar aquela criança que a gente vai ser, que nós seremos os pais daquela criança.

Entrevistador: Tá. 
André: Acho que não existe cor ou... característica de uma criança. Eu, a única coisa que eu queria era uma criança pequena, de colo.

Entrevistador: Hum.

André: ... Pra eu poder ter ela mais tempo comigo, poder cuidar realmente de trocar fralda, tudo. Não pegar uma criança já pronta de cinco aninhos.

Entrevistador: Hum.

André: E não passar a barra de acordar de madrugada pra cuidar dela e essas coisas que eu, que eu gostaria de vivenciar.

Entrevistador: Tá. Bom, acho que o básico que eu tinha pra perguntar, eu perguntei. Tem alguma coisa que eu não te perguntei que você gostaria de dizer?

André: Acho que não, eu falo demais e aí (risos)... acho que... de imediato, de supetão assim, não.. não vejo nenhum pergunta que poderia ser feita, assim. Podia até dá uma dica assim, é, fazer uma pesquisa também voltada a como e a reação dos pais quando descobrem que o filho é homossexual.

Entrevistador: Hum.

André: Acho que é o pior momento da vida do... da... quando você tá se aceitando, você tá percebendo o que você realmente é, é... você abre isso pras pessoas que você mais confia, que são seus pais, acho que é o pior momento da sua vida, que você fica numa fase muito complicada e tem muito casos engraçados, casos... até tristes, mas acho muito interessante, porque é muito difícil essa época.

Entrevistador: Hum... pra você foi?

André: Foi muito difícil, fiquei um ano assim, é, tentei me matar duas vezes, não aceitava em hipótese alguma, não queria, não... eu não acreditava que eu poderia ser gay ou que isso, é... fosse uma coisa válida, é, eu não acreditava que dois homens podiam casar ou que podiam construir uma família

Entrevistador: Hum.

André: É, não convivia, eu não tinha é, assim, amigos na época é... próximos. Aí eu comecei a saí mais, comecei... mudei, né? De casa, pra tentar me descobrir mais, ficar um pouoo longe dos olhares da minha mãe pra tentar ver o que eu podia fazer, ou até onde eu podia ír e eu acho muito, muito, muito válido.

Entrevistador: U-hum.

André: Fazer uma coisa a respeito disso, tem... acho que tem muita coisa pra contar, muita gente...

Entrevistador: U-hum.

André: E cada, cada pessoa vai contar de uma forma, vai ter os seus problemas, suas, suas encanações na sua época, é... eu namorava meninas, eu... namorava até meninas lésbicas, que eu sabia que eram lésbicas, sabia que eu curtia ela mas apenas pra ficar andando de mão dadas na rua pra ninguém perceber. 
Entrevistador: U-hum.

André: É, foi muito complicado a minha fase, essa fase de aceitação, é... acho que é a pior de todas.

Entrevistador: U-hum.

André: Horrível, graças a Deus, já tá muito bem resolvido na minha cabeça. E é bom também as pessoas assim, que... que não tão tão bem resolvidas assim ou que tem algum problema a respeito disso com... com essas, com essas questões ou com essa explicação possam ver o caminho delas. Se é, homo ou gay mesmo ou, tentar se encaminhar.

Entrevistador: Hum.

André: Eu acho interessante. Ninguém merece ficar...

Entrevistador: Acho que é um bom tema.

André: Numa vida dupla.

Entrevistador: U-hum. Acho que é um bom tema. Tá bom, olha, muito obrigado, foi muito boa a entrevista

André: Eu que agradeço. 


\subsection{0 - MAURO}

Mauro: entrevistado.

Geraldo: companheiro de Mauro.

Entrevistador: Vamos falar um pouco sobre a tua história com o seu parceiro. Eu queria que você começasse por onde você quisesse, fizesse os destaques que quisesse e contasse um pouco sobre a história de vocês dois.

Mauro: A gente já tá junto... já faz, agora em maio vai fazer seis anos. A gente se conheceu numa boate. E quando a gente se conheceu, a gente só conversou. A gente não chegou a ficar junto, não aconteceu nada. E... e ele tava com uma outra pessoa na boate... e eu tava com os meus amigos. Aí depois eu fui viajar, passei uma semana, foi um final de semana seguinte, que a gente talvez iria conversar. Eu viajei pra outra cidade. Então a gente foi se ver num outro final de semana. Aí que a gente se viu... e, realmente, foi a primeira vez que a gente ficou junto e começou a se conhecer. Na época a gente morava em cidades diferentes. Eu acredito que depois... eu acho que uns... um ano e meio ou dois anos que eu vim pra cá morar junto.

Entrevistador: Quanto tempo levou até vocês ficarem juntos?

Mauro: Não... depois não... depois que a gente se conheceu na boate, como eu falei... duas semanas depois... dois finais de semana seguintes que a gente começou a ficar junto... e aí a gente foi ficando junto e logo já... já era namoro.... e todo final de semana ele ia pra lá. Raramente eu vinha pra cá, que ele morava com o irmão na época e o irmão ainda não sabia. Então toda sexta-feira à noite ele ia pra lá ou, no máximo, sábado de manhã.

Entrevistador: Hum.

Mauro: Ele ficava o final de semana todo lá e eu morava numa república com mais dois amigos. E, de lá pra cá, a gente vai ficando junto aí acabou virando namoro e depois, acho que uns dois anos que a gente tava ficando junto, a gente... eu vim pra cá e comecei a morar junto com ele. Eu, ele e o irmão... aí depois o irmão casou, foi embora... aí veio a mãe dele.

Entrevistador: E como é que foi esse começo de morar junto?

Mauro: Assim... pra eu e ele não teve problema não. Mas eu e o irmão tivemos sim... mas é... não por questão de... de eu ou ele ser gay... mas é mais por questão mesmo de afinidade.

Entrevistador: Como assim?

Mauro: Porque o irmão tava muito acostumado a ele a fazer tudo pra ele e eu já não concordava que ele tinha que fazer nada pro irmão. Não era... não era nem uma questão de ciúmes dele ter que fazer pra mim... mas é que eu sempre fui muito independente... desde quando eu sai de casa, então o irmão dele já tinha uma certa idade e eu via ele fazendo as coisas pro irmão e eu falava que ele tinha que parar de fazer pro irmão crescer. E... então, assim, eu e o irmão... a gente se... se ranhetava muito nesse sentido. Porque o irmão já sentia... tava acostumado à muita coisa e eu cheguei e já quis tirar, um monte de... de comodidades que ele dava pro irmão... então aí a gente brigava... assim... brigava... tinha discussão... mas de boa... discutia e cinco minutos depois já tinha passado.

Entrevistador: Hum.

Mauro: Graças a Deus nunca teve esse tipo de problema. 
Entrevistador: Tá... e como foi esse início de vida de vocês juntos?

Mauro: Eu acho que foi assim... quando a gente se conheceu mesmo... pela sinceridade... porque quando eu vi... eu lembro... eu lembrava exatamente como ele tava vestido e aí quando a gente conversou por telefone. Eu acho que na segunda-feira... aí ele ligou e falou assim: ah, cê sabe quem tá falando? Aí ele falou assim: ah, é o Geraldo... você lembra de mim, sabe quem tá falando? Aí eu lembro que eu falei: lembro... é uma... era a pessoa que tal e tal... tava assim, assim, assado na boate, com tal calça, com tal camisa... Aí então ele falou assim: nossa... você reparou mesmo, né? Aí eu falei... não... eu marquei... eu guardei e foi interessante também que aí ele falou assim: a gente pode se ver no final de semana? Aí eu falei: olha, nesse final de semana eu vou viajar... mas eu vou pra uma outra boate numa outra cidade... então eu prefiro que a gente converse no outro final de semana.

Entrevistador: Hum.

Mauro: Porque se a gente for se falar essa semana eu não vou falar pra você que eu vou pra boate e não vou... e talvez não vá ficar com ninguém lá... então eu falei: deixa eu ir pra boate que já tava agendada com os meus amigos. Tava tudo combinado... e na semana que vem a gente conversa, a gente se conhece melhor e conversa. E foi legal isso... entendeu? Porque eu acho que foi... houve uma sinceridade e da parte dele também houve uma compreensão e foi legal isso.

Entrevistador: E o que você diria que é o melhor na relação de vocês... e por quê?

Mauro: Eu acho que é o companheirismo... eu acho que eu já... eu já passei por alguns problemas sérios e ele esteve do meu lado e me ajudou bastante e ele... E vice-versa também...entendeu? Problemas diferentes mas eu acho que... o... quando houve os problemas, o outro tava ali pra apoiar... então meu problema sério seria quando eu fiquei desempregado. Ele teve do meu lado pra apoiar e o meu segundo problema sério foi o de saúde que eu tive e ele também teve do meu lado. Já, assim, a... por parte dele... a família dele já é mais difícil de... de.. com relação à relação... então ele tem os problemas da família dele e eu sempre tô do lado pra ajudar.

Entrevistador: Deixa só eu retomar esse ponto... você contou duas situações difíceis... você pode contar um pouco mais sobre elas?

Mauro: A primeira foi quando eu realmente fiquei desempregado... fiquei um bom tempo desempregado e o tempo tava passando, as reservas estavam acabando... financeiras... então aí o Geraldo me ajudou... ele conseguiu através dos contatos que ele tinha... Eu vim pra cá... eu consegui ir trabalhar com um emprego temporário no Banco. Então foi um pouco também da minha vinda pra cá, foi isso... mas aí aqui eu fui ficando. Aí aqui eu comecei a estudar novamente e aí a gente realmente ficou morando junto mesmo... aí casamos mesmo... então, assim, a primeira ajuda que ele... que foi...foi essa...o meu problema... o primeiro problema foi esse: eu perdi o emprego. Então caiu mais numa questão financeira e ele tava ali do lado pra ajudar.

\section{Entrevistador: Hum.}

Mauro: E... porque... mesmo porque minha família não é daqui... não tinha ninguém aqui. Então... ou eu teria que voltar pra minha cidade... pra onde mora... as... a minha família... mas também é bastante complicado... porque meus pais são separados... minha mãe mora com minhas irmãs... então aí envolve morar com as irmãs, com os cunhados, com os sobrinhos. E a segunda foi realmente um problema de saúde... eu tive um tumor... eu tive que passar aí por uma cirurgia às pressas... a gente... eu descobri no fim do ano... mas o Geraldo ficou sabendo... acho que só dois meses depois. E eu escondo (risos). Aí eu fui falar só depois que eu já tinha digerido um pouco a história. A idéia... aí ele começou a perceber que 
eu tava estranho...e... e aí a gente conversou e... e eu acabei abrindo o jogo mas, graças a Deus, a questão de... foi assim... muito rápido... em março eu já tava operando... já tava fazendo tratamento... e, graças a Deus, passou também... mas ele teve ali do meu lado. Então esses foram assim os dois problemas sérios que eu acho que eu passei e por isso que eu falo que isso é legal pra um companheirismo na gente. Um com o outro... e ele tem os problemas que... sérios com ... com a família dele... e eu acho que por eu ser bem mais paciente que ele... ele é mais estopim curto e o meu pavio já é bem mais longo. Eu acho que se não fosse eu na história, assim, não sei se o rumo teria... a... a história teria levado o rumo que levou, entendeu? Que ele é mais estouradão. Então eu fico colocando os panos pra poder esfriar um pouco a... as histórias quando tão muito quente... então acho que esse companheirismo na gente é muito importante. Que acaba sendo um respeito que um tem pelo outro e compreensão.

Entrevistador: E quais você diria que são as coisas mais difíceis na relação de vocês e por quê?

Mauro: A convivência (risos). Porque quando você começa a conviver com outra pessoa... não é só no relacionamento, é com qualquer pessoa que você convive, você acaba dividindo espaço... você acaba div... tendo que aprender a abrir mão de algu... de alguma coisa e também, por outro lado, você tem que ser firme pra também não abrir mão de tudo e fazer com que a outra pessoa abra mão um pouco das coisas. Então essa parte de conviver é muito complicada. E eu sou muito chato com relação às minhas coisas.

Entrevistador: Com o quê?

Mauro: Se você olhar pra trás, por exemplo, na prateleira você vai ver que os meus cds são guardados em ordem alfabética. E se você for lá pedir pra ouvir um eu vou deixar mas provavelmente, na hora que terminar, eu vou perguntar se você colocou no mesmo lugar (risos).

\section{Entrevistador: (risos).}

Mauro: Então esse tipo de coisa é uma... você tem que acabar tendo que entender que nem sempre o outro tem as mesmas manias que você ou faz a mesma coisa que você... entendeu? Então você tem que abrir mão de algumas coisas... então eu sei que em relação a algumas coisas... eu sou... eu sou chato mesmo, eu sou bastante metódico. Mas, por outro lado, ele também tem as dele... então que eu também tenho que conviver com isso... e também algumas vezes tenho que abrir mão e outras vezes eu também não... que tem que...a... ambas as partes tem que ceder... então essa parte de conviver junto é muito complicada... e nós. Assim. temos mais um agravante, né? Porque hoje estamos eu, ele e a mãe dele... mas já chegou... antes... primeiro...foi eu, ele e o irmão... que foi... que acho que foi a fase mais tranqüila, sem problema algum. Não.. não tinha... assim... eu falo que a gente era picuinha...que a gente ficava caçando encrenca... eu e o irmão dele... mas a gente acabava se dando bem. O irmão dele acabava entrando no estilo de vida que eu e o Geraldo tínhamos, o ritmo de vida que a gente tinha, aí depois veio a mãe. No começo foi tranqüilo também... hoje já é mais complicado... porque... aí eu tenho que ficar entrando um pouco na história e amenizar o rumo porque ele e a mãe dele às vezes se estranham... por causa, justamente, por causa do estilo de vida dela e o estilo de vida dele...mas teve uma fase que foi eu, ele, a mãe dele, a irmã e a criança, a sobrinha. Nossa, essa fase foi terrível (risos). Acho que todo mundo aqui nessa casa, tava todo mundo estressado, acho que até os cachorros tavam estressados. Essa fase foi muito difícil... é... eu, particularmente, adoro criança...mas jamais teria uma, entendeu? Adoro criança dos outros... dos meus sobrinhos, dos sobrinhos dele. Vem aqui, vai embora com o pai e com a mãe... ou, se não, vem e fica... e depois devolve. 
Adoro criança... mas da minha parte, em nenhum momento, hoje... eu não... não teria vontade de ter um filho, não.

\section{Entrevistador: Hum.}

Mauro: Ele às vezes pergu... fala... fala que tem vontade... tudo. Mas a gente nunca também sentou pra conversar a sério sobre isso... mas hoje a minha opinião é de não ter. Prefiro ter vinte cachorros do que uma criança. Então acho que foi isso... acho que o pior momento que teve com relação a convivência foi quando nós estávamos aqui em quatro adultos e uma criança.

Entrevistador: Hum. E você acha que a criança...

Mauro: Não... não... não digo que foi só a criança não, entendeu? Não acho que ela não foi o princ... ela não foi o motivo principal não... é que uma criança pra quatro pessoas educarem, sendo que uma é a mãe, o outro é o tio e a outra é a avó. E um é um de fora, um tio postiço. Então é complicado... e ca... e cada um querendo educar de uma maneira... então eu acho que não era a criança o problema e sim acho que nós quatro que não entravamos num consenso. Porque a avó tem aquele jeitão mesmo de educar mais tranquilão... o que os filhos não puderam fazer, os netos podem. Então é... tudo muito complicado... o Geraldo já é bastante rígido com relação à... à criança... à educação de criança. Eu já sou mais maleável... mas ao mesmo tempo, assim, me estressa mais (risos). Então é complicado... então é... era... mas eu acho que o motivo não foi a criança não... foi mesmo a falta de comunicação dos quatro em relação à educação da criança.

Entrevistador: E como é que era sua família de origem?

Mauro: Minha família de origem é... eu e meu pai somos bastante problemáticos... a gente... pra você ter uma noção, hoje a gente não tem relação alguma... mesmo... meus pais se separaram quando eu era adolescente... mesmo quando ele era casado, eu já não me comunicava com ele. Já havia, assim, uma certa problemática entre eu e ele.

Entrevistador: Por conta de quê?

Mauro: Então, era sempre via a minha mãe... eu não... não... até hoje, pra ser sincero, eu não sei te falar o porquê... não acredito que seja pela minha opção sexual, não. Porque na época eu nem sabia... mas é, desde de criança... é.... a gente não se dava muito bem... e eu já cheguei várias vezes até a questionar pra minha mãe se realmente ele era meu pai... teve uma certa fa... fase da adolescência que eu questionei isso, né? E minha mãe, graças a Deus, é uma pessoa excelente e sabe muito, soube educar os quatro filhos e... e sabe conversar muito bem com todos eles.... então é... já cheguei a questionar isso pra ela... mas assim...o que eu... o que marca assim, nessa história dessa problemática comigo e com meu pai, era uma história...uma vez, ele era muito rígido... e eu não lembro disso mas minha mãe que conta... e... que... quando eu era pequenininho a minha irmã mais velha... ele havia falado pra ela que ela tinha que chegar do baile onze horas e ela chegou onze e cinco... e aí, por conta disso, ele levou ela embora pra Brasília. Internou num... num seminário... porque meu pai... meus pais freqüentavam uma igreja... e tirou mesmo a minha irmã da gente... da minha mãe... dos irmãos... e colocou nesse seminário... e minha mãe fala que eu virei pra ele e falei que a partir daquele dia nunca mais eu me dirigia a palavra com ele... e isso minha mãe... minha mãe conta, isso marca muito pra mim... porque minha mãe... minha mãe sabia... que se realmente eu tinha falado aquilo, era verdade. Que minha mãe sabe que quando eu falo alguma coisa, eu não volto atrás... mesmo posso tá lá sofrendo mas eu sou muito orgulhoso em relação a isso... e... e realmente, depois, conforme eu fui crescendo... eu... eu lembro que realmente tudo o que tinha que falar com ele era através da minha mãe: fala pro seu marido que amanhã tem que pagar o dentista, sabe? Desse jeito, não me referia a ele. Se a gente tava 
na mesa, eu conversava com minha mãe pra falar com ele... mas não me ref... não falava, não falava com ele de jeito nenhum e é assim até hoje.

Entrevistador: Hum.

Mauro: A gente pra... até hoje... eu era adolescente. Eles se separaram. Os quatro filhos... eu e minha três irmãs que são mais velhas... acabou todos ficando do lado da minha mãe... porque ele se separou da minha mãe... tinha trinta e três anos de casado. Ele tinha mais de cinqüenta anos e separou da minha mãe por causa de uma moça de vinte e quatro. E a gente acabou ficando do lado da minha mãe... mas minha mãe também conversando e tudo. Os netos foram nascendo... eu conversando com minha irmãs... então hoje minhas irmãs têm contato com ele sem problema algum por causa dos netos. Então ele freqüenta a casa delas... elas vão até a casa dele, levam os netos e tudo mais. Mas eu e ele, realmente, a gente não... não... não tem relação alguma... se eu quero ir na casa da minha avó... eu investigo pra ver se ele tá lá ou não e... e... e acho que a recíproca também é verdadeira... então pra mim hoje é indiferente... aí teve até um caso, assim, interessante. Porque eu falava isso e o Geraldo achava... falava assim: nossa, mas às vezes você exagera. Mas o Geraldo presenciou e ele falou assim: é realmente, é... é até pior... é. Um dia a gente tava na casa da minha irmã onde minha mãe mora e ele chegou, né? Ele chegou e, assim, a sala é dividida por um balcão então da...da cozinha. Eu tava na porta da cozinha e ele tava aqui na sala... e tal. Cumprimentou todo mundo. Eu fiquei ali na cozinha, do jeito que eu tava. Aí eu fui pra... pra sair... minha mãe e minha avó, que é mãe dele, já tava ali, já não deixou. Aí eu já fiquei por ali, por causa da minha avó, de idade e tudo. Aí minha avó e minha mãe ficaram: ah,.cumprimenta ele, cumprimenta ele, num sei o quê, num sei o quê. Aí eu fui pra cumprimenta-lo, aí ele olhou: ah, você tá aí? Nem te vi... então...é... aí o Geraldo naquele dia falou assim: é verdade,.eu achei que você exagerava um pouquinho em relação a seu pai... mas é... acabei de crer que é verdade. E até hoje é assim. Eu não me refiro ele como meu pai, se eu estou falando com minhas irmãs é o seu pai. Ou, se eu tô falando com minha mãe, é seu ex-marido. É assim que é a referência... mas tirando isso... Eu me dou bem com minhas irmãs, graças a Deus, me dou muito bem com minha mãe. Minha mãe, minha irmãs e os meus cunhados, todos aceitam, tratam... é... a família dele me trata melhor... mas a minha família trata melhor ele. E os meus sobrinhos chamam tudo ele de tio e... e quando falam comigo, eles sempre perguntam dele... então, graças a Deus, em relação a isso... não... não tem nenhum problema... a gente se dá muito bem.

Entrevistador: E como é que foi a decisão de ficarem juntos... como é que vocês resolveram ?

Mauro: Então, foi aquilo que eu tava falando. Quando eu fiquei desempregado, que aí eu consegui... o Geraldo conseguiu um trabalho aqui pra mim... então foi uma coisa assim que... meio que... a princípio... é o... foi unindo o útil ao agradável...o trabalho era aqui... eu tinha que ficar aqui... eu tava... fui ficando aqui... e... mas, assim, até então... quando eu vim... é... cada um tinha sua cama. A gente, às vezes, pra dormir junto a gente colocava o colchão no chão e tudo mais. Depois, assim, quando o irmão.. o irmão saiu... que a gente colocou mesmo a cama de casal no quarto e foi até interessante que depois que o irmão dele saiu... a primeira cama de casal que veio foi através do irmão dele. Aí depois que a gente comprou uma cama melhor... e aí a mãe do Geraldo veio. Aí essa cama foi pra lá, então, assim, não foi... na verdade não houve uma... uma... a gente não sentou e falou: vamos morar junto, vamos casar? Não... num houve... ele falou: vamos? Que eu tava sem trabalho lá... tava difícil. Ele falou assim: ah, vamos lá pra casa... cê vai trabalhar no Banco... você fica lá comigo e tal. Então foi uma coisa assim que, unindo o útil ao agradável, não teve uma conversa séria. Ah, vamos morar juntos. Foi uma consequiência natural do relacionamento... 
Entrevistador: E você me contou uma parte disso... mas eu queria ouvir como é que os membros da tua família de origem se relacionam com teu parceiro e eu queria que...se você puder... que você contasse uma situação, a título de exemplo, de como é essa relação.

Mauro: É... eles se dão super bem... são várias situações... a primeira vez que a gente foi pra casa da minha irmã... a minha mãe...ela pegou e na... a gente foi dormir... minha mãe foi lá, colocou os dois colchões de solteiro e pegou um... um... um lençol de... de casal e montou a cama de casal junto, né? Aí o Geraldo falou: nossa, que legal, não sei o quê. E aí... aí meu...aí meu cunhado também, no mesmo... nesse mesmo final de semana... a gente, tipo assim, foi lá pra... pra lá na sexta-feira. Aí no sábado meu cunhado queria ir dormir fora com minha irmã, pra que a gente pudesse dormir na cama deles, entendeu? Então é... é assim. Hoje as minhas irmãs, elas gostam tanto dele que eu não posso falar nada... não é nem questão de implicância, mas se, por exemplo, eu falo... Geraldo, tira esse copo daqui e põe ali, senão as crianças vão derrubar... Elas acham que eu tô implicando e já começam a brigar comigo pra deixar ele em paz. Alguma coisa desse tipo, sabe? Protegendo ele... então...é...é... assim hoje... são... as... as pequenas atitudes demonstram acho que o carinho que... que a fa... a minha família tem por ele, os meus sobrinhos e tudo mais.

Entrevistador: E me conta uma coisa... você tem acompanhado o debate sobre adoção por casais gays?

Mauro: Não.

Entrevistador: E sobre a união estável? Você tem acompanhado?

Mauro: Não, também não. O pouco que eu sei é através de um amigo nosso em comum... que na maioria das vezes, nessas informações, assim, é tudo via ele que a gente consegue. Ou ele manda um e-mail... ou ele man... às vezes quando tem alguma coisa assim ele até liga... por ou... o lugar que eu trabalho, por não poder atender ligação pessoal, então ele fala mais com o Geraldo. Onde o Geraldo trabalha é mais flexível. Então às vezes ele liga e fala que vai ter uma reunião aqui ou vai ter algum acontecimento. Alguma coisa. Então a gente fica inteirado através dele que vai passando as informações pra gente... mas eu, particularmente, não... assim pesquisar e tudo mais... eu não, não tenho feito. Não é nem por... por... por uma questão de interesse... é mais mesmo por falta de tempo, por incrível que pareça... é o meu... outro... o pessoal fala assim: ah, tempo é a gente que faz. Mas o meu, por enquanto, não tá nesse... isso não... eu acordo quatro e meia da manhã, vou dormir meia noite e meia... então, assim.

Entrevistador: Muito trabalho?

Mauro: Muito... eu não tenho tempo mesmo.

Entrevistador: Ok, e o que é família pra você?

Mauro: Eu acho que família é justamente isso... é aquilo que eu um pouco tava falando no começo, né? Eu acho que é companheirismo, é respeito, é a gente se adequar, a conviver com as diferenças... é...é... é ter uma... uma organização, porque quando o pessoal faz: ah, família! Tudo bem, família tem que ter amor, tem que ter carinho, tem que ter respeito, tem que ter todos esses sentimentos que a gente já sabe que faz parte mesmo de uma relação com uma outra pessoa, de uma relação com a mãe, com os pais, com os filhos e tudo mais... mas, assim, mas fora isso... infelizmente ou felizmente... a gente vive num mundo capitalista. Então a família, você tem que ter também a questão de... de você saber se organizar... de você organi... organizar as finanças porque senão você não tem como sobreviver.. eu tenho esse hábito... por exemplo... eu se vou comprar qualquer coisa... se vou comprar uma bala, eu sempre aviso o Geraldo, eu falo que eu vou comprar tal coisa, justamente pela questão de 
organizar mesmo... pra se planejar... eu fa... eu tenho esse hábito... então... acho que é tudo isso... esse conjunto todo eu acho que é a família. Não é só... eu acho que não é só a parte sentimental, não. Tem... a gente tá num mundo capitalista... temos que ser real e tem isso.... e isso faz parte também de uma família.

Entrevistador: E tem alguma situação que você possa contar que mostre como é a sua família?

Mauro: Ah... eu acho... assim... é uma pequena coisa que... uma pequena atitude... mas, assim, foi fazendo a diferença com o passar do tempo. No começo a gente tinha muita preocupação justam... principalmente assim por se tratar de uma cidade pequena e pela família dele, que até então não sabia...e... e realmente até hoje a gente nunca sentou e conversou com ninguém abertamente sobre isso... mas havia uma certa preocupação numa... no tratamento um com... um com o outro... a maneira como... como chamar... como conversar... porque de repente a gente tava... era Geraldo... era Gê... e houve várias situações. Eu me policiava tanto justamente por ser a... a parte da família dele que um dia aconteceu naturalmente e foram... foi em seguida assim... parece que naquela semana foi acontecendo... todo dia foi acontecendo uma. Teve um dia... a gente... ele tava na... fazendo alguma coisa na tia dele... e ele tava em cima da escada... eu tava no chão... aí ele virou: amor, pega isso pra mim. E tava todo mundo na casa da tia dele perto... e ele falou tão naturalmente que ele... ele percebeu bem depois que ele falou. Eu percebi na hora e fiquei um pouco sem reação. A tia dele, pra não deixar constrangida, saiu meio que da sala... e, acho que passou alguns segundos, ele... ele caiu na real que ele tinha falado. Aí logo em seguida... foram acontecendo isso naturalmente, sabe? Então essas... essas ações... essas atitudes que vão acontecendo da maneira de... de tratamento de... das palavras usadas... a forma de... de carinho... um com o outro... isso... isso foi acontecendo tão naturalmente que acabou não tendo que explicar nada pra ninguém. Todo mundo ao redor percebeu e, se aceitou ou concordou, ou não, ninguém questionou... ninguém falou nada mas também ninguém se afastou. Então por isso que a gente acredita que não há problema nenhum. A gente achava que o problema maior seria o irmão dele em relação a isso e não, pelo contrário, o irmão dele é uma das pessoas que mais tratam a gente bem, mais ajudam a gente. Então acho que essas é... é... esses fatos que foram acontecendo naturalmente... foi... foram demonstrando a... a relação que a gente tem um com o outro... e foi deixando isso claro tanto pra família, até mesmo pra sociedade... porque isso já aconteceu também várias vezes fora, né? Num mercado, em vários outros lugares.

Entrevistador: Isso eu ia perguntar... antes da gente começar a conversar você tinha me contado um pouco sobre a cidade em relação a esse assunto... a preocupação de vocês em ser o primeiro casal daqui que mora junto... Como é isso?

Mauro: Em mim não foi tanto não... porque eu já tinha... eu já vinha, assim, quando eu me relacionei com o Geraldo... a minha família já sabia... então eu já tinha tido um... um outro relacionamento, né? Então minha família já sabia. O meu processo de falar com a família... que, na verdade, eu sempre achei que eu tenho que dar satisfação só pra minha mãe... mas eu já tinha feito isso, eu já tinha falado, sentado, já tinha dado essa satisfação pra minha mãe. Então eu já não tinha mais esse problema de ter que mascarar alguma coisa. E... e em relacionamento sério mesmo assim de... que foram passando vários meses e ir morar junto da parte do Geraldo foi o primeiro... então a preocupação maior era dele... hoje não existe mais. Mas no começo havia bastante essa preocupação... e até mesmo não por ele... mas até pelos amigos dele daqui que hoje são amigos nossos em comum... que também têm essa preocupação ou que a família não sabe, então... Por exemplo, tem um amigo que é muito amigo dele que vinha sempre aqui e tudo mais. Mas, quando a gente começou a morar junto, que começaram a surgir alguns comentários, ele se afastou um pouco. A gente demorou pra ir pra... pra casa dele porque um dia a mãe... eu não lembro se foi... foi a mãe ou o pai desse 
amigo que perguntou pra ele sobre a gente. Então ele deu uma afastada. Demorou pra gente. O Geraldo ia muito na casa dele. O Geraldo não... não foi mais, entendeu? Assim, então até mesmo os amigos dele acabavam impondo isso pra ele.

\section{Entrevistador: Sim}

Mauro: Entendeu? Então... mas aí depois passou também mas eu nunca forcei nada, nunca obriguei ele a nada. Tem que ser assim, você tem que abrir o jogo, eu acho que cada um tem o seu limite tem o seu tempo pra isso e saber onde tá pisando, entendeu? Porque a gente procura assim... eu não... como... tem... claro... a gente tá junto... então um e outro fala: ah, eu acho que se você fizer isso é melhor, se você fizer aquilo é melhor, mas a gente num... num entra em... em problemas mesmo da família um do outro, sabe? Se eu tenho meus problemas com minha família, ele fala: faz isso. conversa com sua mãe, não sei o quê... não sei o quê e tal... mas ele nunca foi lá e teve a atitude de ir fazer, entendeu? Me apresentando e vice-versa. Tem as coisas na família dele... então eu fico auxiliando na retaguarda.

Entrevistador: Hum.

Mauro: Porque aí quem vai mesmo dar a cara a tapa é ele (risos).

Entrevistador: Tá bom... teve alguma coisa que eu não te perguntei que você acha que é importante falar. Que você gostaria de registrar?

Mauro: Não... na minha parte, eu acho que não houve não... a gente não... não entrou só na parte de questão de... da parte profissional, de aceitar isso ou não. Mas talvez como... justamente porque todos os empregos que eu tive eu nunca tive problema em relação a isso...

\section{Entrevistador: É?}

Mauro: Entendeu? Então, desde que eu tô com o Geraldo, todos... ou melhor quando eu conheci o Geraldo... daquele... daquele emprego em diante... todos os meus empregos que eu tive... todos souberam que ele existia, da existência dele e quando eu fiquei desempregado desse emprego... todo mundo conhecia, gostava muito dele. Hoje, no meu atual, também tem o pessoal que adora ele.... tem uma... eu chamo ela de paraguaia, mas ela é chilena (risos). Eu falo que ela é falsificada. Nossa, ela tem um quê com ele. Ela adora ele, até mesmo porque ele tá ajudando ela a resolver algumas coisas... mas ela tem uma paixão por ele enorme. Então, assim, a única coisa que a gente não entrou especificamente foi em relação a isso, né? O profissional... na parte profissional como lidaria com isso, né? Mas é porque não tenho nenhum problema, não tenho esse tipo de problema... então por isso que eu acho que eu nem me importei em entrar no assunto... mas, assim, só colocando... porque, talvez, não sei se... se... isso vai te ajudar na sua pesquisa, né? No profissional tem que ficar assim... meio que... meio às escondidas... porque talvez a empresa não aceite... alguma coisa assim... eu uso brinco em todos os empregos que eu vou e nunca fui questionado... já o dele... já não pode... cabelo comprido nem brinco... Uma dureza. Mas é isso. 


\subsection{1 - ROGÉRIO}

Rogério: entrevistado.

Henrique: parceiro de Rogério

Entrevistador: Eu queria que a gente conversasse um pouco sobre a tua história com o teu parceiro e queria que você me contasse um pouco dessa história, começando por onde você quiser, fazendo os destaques que você quiser. O que você pode me contar da história de vocês?

Rogério: Nossa senhora, tem chão, hein filho? Anos juntos, é muita história, né? Mas eu e o Henrique. Nós, (inaudível) faz mais de dez anos que a gente ta junto, de união. A gente resolveu fazer um casamento, isso foi há uns cinco anos, aí diz que aquele casal é o primeiro do Brasil. É mentira! (risos)

Entrevistador: É, isso eu já sabia... (risos)

Rogério: Aí resolvemos, resolvemos, casamos, tudo. Aí surgiu a vontade de filhos, né? No final dos anos noventa a gente entrou com um pedido de adoção. Não deu certo, na época, por uma série de fatores que eu acho que é irrelevante nessa, nessa hora. Aí, como o Henrique tava doente e tudo, resolvemos não recorrer. Não deu tempo, né? Aí resolvemos entrar de novo, duas vezes. Até que deu certo mas, assim, são mais de dez anos, muita coisa pra contar.

Entrevistador: Me conta um pouco quando vocês resolveram formalizar a união de vocês... como é que foi isso?

Rogério: Na verdade a gente resolveu fazer uma união. Não foi nada, assim. É... em questão de justiça. Mesmo porque a justiça hoje em dia ainda não permite esse tipo de união, né? Então você pode firmar um contrato, alguma coisa assim. Mas a justiça brasileira não reconhece a união entre duas pessoas do mesmo sexo. É isso, existe um contrato que você pode fazer, registrar em cartório e tudo. Mas foi uma cerimônia religiosa que nós fizemos, não foi nem religião, foi numa cerimônia ecumênica que não é uma religião. E resolvemos fazer essa união, já fazia tanto tempo que tava junto aí resolvemos, assim, sem motivo específico. Ah, porque a gente quer... fizemos porque deu vontade... (risos) Só por isso.

Entrevistador: E se você fosse me dizer o que é o melhor da relação de vocês, o que que você destacaria?

Rogério: Oh, muitos anos, você sabe que não é fácil, é uma vida juntos, né? E eu e o Henrique, a gente convive vinte e quatro horas juntos porque a gente tem a mesma profissão. A gente trabalha no mesmo lugar, né? A gente convive o dia todo juntos, a gente acorda junto, dorme junto, trabalha junto, então é uma coisa, assim, já é complicado você viver durante muito tempo com uma pessoa. Convivendo tanto todo dia, você sabe como é que é. Eu acho, assim, que pra nossa relação o que você pode destacar é que a gente conversa muito, a gente tem muito diálogo, sabe? Então, se tá acontecendo alguma coisa, a gente senta, conversa, tenta resolver numa boa, nós não brigamos, é muito difícil eu e o Henrique... a gente brigar. Nesse tempo todo se falar pra você, ah... briga... porque todo casal briga mas a gente não briga. É incrível como a gente não... a gente conversa muito. Acho que esse é o ponto forte da relação, sabe? Muito diálogo, acho que o importante é isso. Sempre, sempre foi desse jeito. A gente conversa, a gente tem muito diálogo. Eu acho legal, não só na nossa relação, mas em toda relação tem que ter isso, não é Luiz? Porque eu acho, assim, o diálogo 
é a base de tudo, se você não aprende a ter paciência, se você não aprende a tentar resolver junto, você não convive muito tempo com uma pessoa. Você pode até conviver mas é aquela convivência que chega uma hora que não vai dar certo. Que você cansa, sabe? Você fica mais por obrigação do que por desejo. É complicado. Você tem que abrir mão de muitas coisas... né? E a outra pessoa também, você sabe como é que é, é você ceder de um canto, a outra pessoa ceder do outro.

Entrevistador: E me conta uma coisa: o que é o mais difícil da relação de vocês? E por que?

Rogério: Pra mim, né? Pra mim é, eu não vejo grande dificuldade, a única coisa que eu fico muito irritado é que o Henrique é muito, como é que eu acho, ele é leonino, não preciso falar mais nada, né? Ele é autoritário, ele acha que só ele tem razão, esse tipo de coisa. Mas ele só ruge também, viu? Não deixa ele achar que ele manda não (risos), que ele faz, que ele acontece. Mas eu acho que é isso, o que me irrita é isso mas, tirando isso, sem problema nenhum. Já aprendi a conviver com isso... eu já nem abro mais a boca... deixo ele achar que tá mandando (risos).

Entrevistador: E tem alguma situação que você acha que poderiam mostrar como é a relação de vocês?

Rogério: Ai, eu não, não sei de imediato. Não consigo lembrar de alguma coisa. A gente tem muitas histórias, eu não sei qual delas definiria isso... não... realmente. Vamos pra próxima pergunta?

Entrevistador: Então me conta o seguinte, como era sua família de origem?

Rogério: Meu pai e minha mãe? Eu sou filho único. Eu tenho um irmão de criação que na verdade é um primo, mas eu sou, por parte de pai, o único filho neto e sobrinho... Mas a minha família não, eu, pessoalmente... O Henrique deve ter tido alguns problemas com a família dele, mas eu não sofri problema nenhum, meu pai era muito trabalhador, minha mãe uma pessoa super simpática, minha casa vivia lotada de gente por conta da simpatia dela. Mas, não, nunca me perguntaram nada, nunca sofri nenhum tipo de preconceito deles em relação ao homossexua... à homossexualidade... não é mais ismo, né? Ismo agora é doença, eu não sou doente (risos) Uma família super simpática, eu definiria assim. Meu pai super... uma pessoa... meu pai era muito caseiro, muito amoroso. Minha mãe muito dedicada, muito trabalhadora também, eu acho que minha família é praticamente normal. Eu acho, sem problemas, sem problemas.

Entrevistador: E como é que foi a decisão de vocês dois ficarem juntos? Como é que vocês decidiram isso?

Rogério: Ah,. chega uma hora que você deseja, você sabe que o ser humano não nasceu pra viver sozinho, né? Nenhum ser humano nasceu pra viver sozinho, ele tem necessidade de tá junto de outra pessoa, de receber afeto e de dar afeto. Você sabe que é assim, você deve ser assim, sua esposa é assim, todo mundo é assim, por que você casou com sua esposa? Porque você começou a sentir um... você teve um sentimento, você teve uma atração maior e você decidiu ficar com essa pessoa junto de você, né? Não basta você ter sentimento e essa pessoa tá longe, você tem necess... você, o ser humano, tem carência de pegar, de... aquela coisa física, né? De tá junto, de tá perto, de partilhar os momentos ruins e os bons. Então eu conheci o Henrique em outra cidade, decidimos tudo, eu já tava também com vontade de ficar com alguém. Chega uma hora que você cansa de só ficar na... na... na gandaia, né? Então viemos ficar juntos, fomos ficando, ficando, até hoje é uma coisa meio... mas eu definiria assim: o ser humano não nasce pra ficar sozinho nunca, né? Sempre... de uma maneira ou de outra. Sabe aquela: toda panela tem a sua tampa? Bem por aí a história. (risos) 
Entrevistador: E como é que os... como é que os membros da tua família de origem se relacionam com o Henrique?

Rogério: Bom... eu vou te dizer da minha família em relação a ele... da família dele em relação a mim... no começo eu sofri alguns certos de... não foi nem preconceito mas o pai dele não aceitava muito no começo essa idéia.

Entrevistador: É?

Rogério: Não, porque o pai dele não, não tinha... Como é que eu posso te dizer? Não tinha convivido com ninguém homossexual na época. Então era aquele tipo de preconceito que existe, que acha que o homossexual põe vestido, salto alto, batom na boca e fica na esquina, entendeu? Generaliza a coisa, né? Por não conhecer então no começo eu sofri um certo, assim, é... um certo preconceito da família em relação a isso. Agora, a minha família em relação ao Henrique, foi o que eu te falei, meu pai e minha mãe nunca me questionaram nada, nunca me perguntaram nada. Hoje a gente já não tem nem pai nem mãe, nem eu nem o Henrique, né? Eu não conheci a mãe dele, nem ele a minha, nós conhecemos apenas os pais. Ele conheceu meu pai e eu conheci o pai dele... é... mas legal, numa boa, meu pai aceitou numa boa, nunca me perguntou nada, né? Mesmo porque eu trabalhava, tinha minha renda e eu acho que ele se, ele se sen... ele não se acha no direito de me questionar sobre alguma coisa, né? É... eu, apesar de ser filho único, minha mãe me educou de uma maneira que eu sempre tive que trabalhar pra conseguir o que eu queria, né? É... então eu trabalhava, tinha minha vida, andava sozinho então meu pai não me questionou nada, como eu te falei. Ele não se acha, ele achava que não tinha o direito de me perguntar. Mas meu pai em casa... é... assim... é... ele aceitava tanto a idéia que ele ia na minha casa às vezes de final de semana. Ele dormia na sala e eu e o Henrique íamos pro quarto na cama de casal dormir tranqüilo, levantava, numa boa, nunca falou nada em relação a isso. O Henrique sempre freqüentou a casa do meu pai, da minha mãe, das minhas tias, da minha avó e todo mundo, assim, aceitou numa boa, né? hoje ele é... é sobrinho adotivo... neto adotivo... tanto que ele chama as minhas tias de tia, A minha avó... então legal... assim, minha família em relação a ele, sem problemas. Domingo passado tinha um pessoal aqui da TV, eles vieram fazer um documentário com a gente... ficaram uns dias aqui gravando. Aí eles quiseram que domingo a gente reunisse a família, pra ele poder gravar um momento nosso com a família. Aí minha avó, que veio aqui em casa, fez almo... fez a feijoada, fez almoço pra todo mundo, tinha umas vinte pessoas aqui em casa, da minha família. Então tudo, assim, tranquiilo.

Entrevistador: E você tem acompanhado o debate sobre adoção e sobre união estável por casais gays?

Rogério: Tenho...

Entrevistador: Tem?

Rogério: Tenho... e eu tenho... e eu procuro ficar a par disso também, porque eu acho que nosso caso, ele criou jurisprudência, entendeu?

Entrevistador: Sim...

Rogério: Então eu acho assim... legal eu tá a par... porque muita gente, mesmo... Oh, já vai fazer três anos que eu tô com a nossa filha e ainda hoje ligam pessoas aqui pra me perguntar sobre adoção, pra eu dar o telefone do nosso advogado, que às vezes tá com problema de adoção, então eu procuro sempre tá a par. Que nem hoje, eu recebi um e-mail dizendo que dia 29 agora parece que foi aprovado o cadastro único de adoção, né? Que levaram pra todo 
o Brasil. Quer dizer, se tiver, eu tô na fila ainda, né? Nós estamos na fila ainda... Eu pretendo adotar uma irmãzinha pra minha filha... é... se eu achar uma menina lá em outra cidade, que eu me interessar, eu posso ir lá pegar a menina porque o cadastro agora é único. Ele não serve só pro meu município, que nem era antes, eu acho legal esse tipo de coisa mas eu tô, tô sempre a par sim. Eu acho que a sociedade brasileira mudou muito, né? Eu acho que a mentalidade... eu acho que não é que ela mudou... Eu acho que tá na hora da sociedade brasileira acordar e ver que... é... o conceito de família hoje em dia mudou muito, né? Não é mais que nem era no tempo da nossa avó, que era mamãe, papai e filhinho. E a mulher era totalmente submissa, o homem que saía pra trabalhar, a mulher ficava em casa cuidando dos filhos e o homem traía... fazia o que queria, a tonta tinha que ficar lá e ainda abrir as pernas pra ele... Então a sociedade mudou muito, né? A mentalidade mudou muito, a estrutura familiar mudou muito. Hoje em dia, infelizmente, é aqueles políticos que estão lá em Brasília, a maioria aqueles senhores caquéticos lá que não... não consegue evoluir, mas nem com bomba... acho que nem depois de morto vai evoluir o espírito daqueles trens... Eu acho que eles tinham que ver que não tem nada a ver. Hoje você tem uma família que é formada de um pai só, de uma mãe só, de um, de uma... de uma família que os avós criam o neto, sabe? Que tem mãe solteira, que tem pai solteiro, que tem dois pais, que tem duas mães então a sociedade, a estrutura familiar hoje em dia já não é mais como era há cem anos atrás. Infelizmente existem pessoas que atravancam a lei ainda... achando que o certo, como eu já ouvi falar muito, né? Infelizmente, por parte da Igreja, que o certo é a família é papai, mamãe e filhinho. Eu sou excomungado pela igreja católica. Cheguei a falar isso com um padre num debate ao vivo numa TV que eu tava... a... o cara depois veio me pedir desculpas, né? Aí eu falei assim: bom, eu não entendo porque vocês se contradizem, né? A igreja se contradiz porque ela vai contra o preceito maior do... do... do Cristianismo, que é amar ao próximo como a si mesmo. Agora, se eu tô querendo pegar uma pessoa que eu não tenho laço sanguíneo nenhum... eu pretendo pegar essa pessoa, dar casa, comida, carinho, atenção, afeto, escola... é... tentar formar uma personalidade de uma pessoa decente que, se ficasse numa instituição, possivelmente deveria virar prostituta, drogado, alguma coisa assim... Então eu tô doando um amor incondicional a uma pessoa que eu nem sequer conheço... e a... e infelizmente vem pessoas e falam assim: ah, isso é errado. Então, se isso é errado, eu não sei o que é o certo, né? Então é complicado você mexer com isso, eles tinham que parar pra pensar, né? Na verdade não pensam no bem estar da criança, estão pensando no lado da igreja, no lado deles e achando que tá certo. Fazer o que, né? Não tem muito o que fazer... a gente pode falar, falar, como eu já cansei de falar, mas pelo jeito não muda muito. É esperar, né? Que isso mude um dia... vamos ver... Tomara que eles acordem pra realidade... né? É porque os filhos deles nunca ficaram em instituição, por isso que eles não pensam dessa maneira, nem eles tentaram adotar alguém também. Por isso.

Entrevistador: E, Rogério, o que é família pra você?

Rogério: Eu acho que família é união... família é amor... família é diálogo... família é educação... só que eu acho que tudo isso... eu acho que, independente de qualquer coisa, é... você cria vínculos e laços familiares pelos exemplos que você dá pro seu filho, entendeu? Seja homo, seja hetero... seja vô, seja tio, seja quem crie essa criança. Eu acho que o exemplo maior que você dá pra esse tipo de criança são... os seus atos... é... o que você faz da sua vida... e exemplos que ele pode adquirir, né? Com o passar do tempo... olhando e vendo suas atitudes mas eu acho que família é uma coisa também muito complexa, né? Você tá criando outro ser humano, quando eu digo em relação a filhos, porque você forma a personalidade, né? Então é meio complicado, você tem que saber lidar com isso... é... você tem que tá estruturado pra isso, né? Então... é... eu não sei... eu acho que é tudo isso... é uma mistura... (risos) junta tudo e dá uma família...

Entrevistador: Você falou em estar estruturado, deixa eu te perguntar: quando vocês adotaram, vocês acham que estavam estruturados? 
Rogério: Por isso que eu te falei, em 2001 a gente não tava, por várias motivos. O juiz indeferiu o pedido. $\mathrm{Na}$ época eu fiquei revoltado mas hoje analisando friamente, friamente... na época eu não tava estruturado pra ter filho, né? O pai do Henrique tava doente, eu não tinha casa própria na época, eu tava acabando de chegar na cidade, porque eu não era daqui, eu vim de fora é... então, assim,. não tava mesmo na época... preparado nem estruturado pra receber uma criança. Alguns anos depois já mudou totalmente. Eu já tava com casa, com carro, já tava estabilizado financeiramente. Já fazia dez anos que eu tava aqui, praticamente, então eu já tava com outra mentalidade, já tava muito mais preparado pra receber essa criança, tanto financeira, como psicologicamente, né? Então eu tava... tava não... eu ainda estou (risos)... A gente passa por uma análise psico-social, né? Então, se elas acharem que você não tá preparado, que você é doido da cabeça, que você não vai dar comida pra essa criança, porque eles acham que criança é animal, sabe? Você dando comida e cama, tá bom... eles acham que é isso... mas... é... você passa por essa análise... né? Eu passei duas vezes... por sinal... Chegou a última vez, eu virei pro psicólogo, o cara, cê tá achando que eu sou doido? Para com isso, falei pra ele. O homem me trancou na sala dele e ficou uma hora e meia fazendo umas pergunta besta do inferno... (risos) Eu falei: tá achando que eu sou o quê? Retardado...? (risos) Pára... eu saí de lá e falei: pronto esse homem não vai me dar essa criança nunca...(risos) E deu!

Entrevistador: (risos) Ok, e me conta uma coisa, quando vocês adotaram, vocês tiveram critérios específicos quando vocês adotaram?

Rogério: Quando você vai adotar uma criança, você vai no Fórum, primeiro você vai no fórum, você vai lá no Fórum e fala assim: oh, eu quero adotar uma criança, né? Eles vão te dar um relatório de mais ou menos... quarenta, cinqüenta perguntas e nesse relatório você especifica cor, idade, sexo... é... tipo de cabelo. É isso, se você aceita criança doente com doença curável ou não, se você aceita portadores de AIDS, se você aceita filhos de estupro, eles te perguntam tudo... é um relatório que eles te perguntam tudo. Então você preenche esse questionário e entrega de volta, mas a única especificação quando nós fizemos é que eu não queria bebê, né? Eu queria uma menina de dois a quatro anos... é... não importava cor, nem cabelo, isso pra mim não importava mas a única especif... a única coisa específica foi isso. Porque a maioria, infelizmente, quer bebê de olhos azuis, né? Os pais... os pais... é...os pais, de uma maneira ou de outra... mas foi isso... a única coisa específica foi isso, nada demais, é só a faixa etária... né? Menina porque eu acho que a gente se identifica mais... é... eu, você já percebeu que não daria... não daria certo eu ir num campo de futebol com um moleque, né? (risos)

Entrevistador: (risos).

Rogério: Imagina... que eu não ia jogar bola com ele nunca. Então é uma coisa que eu, acho que a gente se identifica mais com menina, né? É pulseirinha, brinquinho, cor de rosa, esse tipo de coisa... e... é... o outro lado bebê... A gente trabalha muito, né? E bebê... você teve seu bebê outro dia... tem com cólica.

Entrevistador: É...

Rogério: Então você tem que, assim, dar atenção vinte e quatro horas... e, infelizmente, eu até dou atenção mas eu não tenho esse tipo de atenção... entendeu? De ficar em cima vinte e quatro horas no colo... é... eu não... a gente não tem muito tempo... a gente trabalha muito... então foi por isso que eu escolhi de dois a quatro anos, já tava grande, maior, já era mais fácil da gente lidar, tudo, foi por isso. E eu também achava que, de bebê, ia demorar mais pra eu conseguir a adoção. Então foi por causa desses três fatores aí, só isso. 
Entrevistador: Rogério, eu acho que o básico que tinha pra te perguntar já perguntei... eu queria te perg...

Rogério: Acabou? Agora que eu embalei aqui! (risos)

Entrevistador: (risos) Bom... então eu vou te pedir duas coisas;...primeiro assim... ficou uma pergunta lá atrás, eu te perguntei pra você me contar um pouco sobre a relação de vocês dois, fazendo alguns destaques. E eu pedi depois pra você contar alguma situação que você achasse que poderia ilustrar melhor como é essa relação. Você me disse: vou pensar um pouco... Então sobrou essa pergunta: eu queria saber, do que eu não perguntei, talvez tenham coisas que você queira falar a respeito mas que eu não perguntei... então eu queria deixar um espaço aberto pra você dizer o que você quiser.

Rogério: ...você vê como mudou a mentalidade... né? Aos poucos... e, infelizmente, vai ter que ser aos poucos... Só que eu vou te falar uma coisa, viu Luiz? Isso é uma onda que tá vindo e que ninguém vai segurar, né? Então é uma coisa que, querendo ou não querendo, eles vão ter que aceitar esse novo tipo de união e esse novo tipo de família. Porque é uma coisa que tá vindo, a sociedade tá mudando. Hoje eles dizem que... que os homossexuais tão errados mas me fala uma coisa: e se a grande maioria da sociedade fosse homossexual... quem estaria errado aí? Então, tudo o que é minoria, você sabe que sofre preconceito... né? Então é um tipo de coisa que é... eles têm que parar realmente pra pensar o que tão fazendo e o que tão falando... mas tá aí, é uma coisa que ninguém vai segurar. Nós somos os primeiros, tem um pessoal, tem um casal de Ribeirão que parece que tá com a guarda de algumas crianças. É... eu não sei como é que tá o caso deles... eles sumiram da mídia... não... não apareceram mais. Eu só sei que eles tão lançando um livro, parece? Tomara que eles consigam a adoção, nós não vamos mais ser os únicos... entendeu? E é uma coisa que... já tem um pessoal do Acre... parece que um casal feminino no Acre já conseguiu uma adoção, duas mulheres, um casal de mulheres no Rio Grande do Sul e outra no Rio de Janeiro. Só que, nesse caso, uma das duas eram... bio... eram... era mãe biológica, mas a parceira conseguiu colocar o nome no registro. Então é o tipo de coisa que tá vindo e que ninguém vai segurar. E tomara que eles consigam ver isso e... e.... tentem agilizar, né? Mudar essa lei que tá tão retrógrada, a gente precisa mudar isso, né? O que vai acontecer com esse país? Eu vou morrer e não vou ver isso ainda... mas que as futuras gerações sofram menos, né? Mas eu não acredito que isso vai ser pra logo não, viu, Lu? Vai demorar... vai demorar muito e tomara... tomara que mude logo... mas não vai, né? Vamos ver o que acontece. Mas o que eu penso taí.

Entrevistador: Eu te agradeço muito pela entrevista. 


\subsection{2 - ALOÍSIO}

Entrevistado: Aloísio.

Jorge: companheiro de Aloísio.

Entrevistador: Então vamos fazer o seguinte, queria que você me contasse um pouco sobre a história tua com teu parceiro, começando por onde quiser e fazendo, fazendo os destaques que você quiser. O que você pode me contar sobre a história de vocês dois?

Aloísio: Ó, eu... eu nasci em São Paulo, morei a vida inteira lá em São Paulo, depois meus pais mudaram pro interior, pro interior. E... aí quando eu mudei, eu fazia teatro. E... trabalhava, né? Em jornal e... fazia teatro, e... saía, tudo, de noite, e numa dessas saídas à noite acabei conhecendo o Jorge através de um amigo, tal, acabei conhecendo ele e a gente acabou se envolvendo. É... é... é... a gente... você quer resumida essa história, ou... com detalhes, com é que é? A gente se conheceu e... e o Jorge me encantou, tal, foi recíproco e... a gente já foi... fomos morar juntos e foi aí quando eu assumi a minha homossexualidade. Até aí então eu nunca tinha tido nenhum relacionamento homossexual é... o... aí logo eu já falei com os meus pais, que eu era... que... que eu queria, que eu tinha conhecido uma pessoa, que era outro homem, e me assumi perante minha família, né? Meu pai não gostou muito da idéia, tudo, né? Mas eu falei: olha, tô bem, eu tô feliz é isso que eu quero e, se vocês... não quiserem, num me aceitarem, eu vou embora, tudo, paciência, né? Mas eu quero viver minha vida do jeito que eu quiser. Eu quero viver minha vida do jeito que ninguém... não do jeito que as outras pessoas querem, e... nisso eu fiquei com... fui morar junto com o Jorge. Aí nós tivemos aquele começo... namoro, tudo, é... passamos por muitas dificuldades no começo, porque é assim... você é muito... você... quando você assume, tudo, a sua família num te apóia, quando você num faz o que eles querem, né? Então... a gente passou por necessidades financeira, é... ficamos desempregados, montamos um bar, esse bar as... era um bar GLS, e esse bar, a gente tinha... passamos muita necessidade porque tinha que ter comida, tinha que ter bebida, e a gente não podia comer porque senão faltava quando o cliente pedia, então a gente... passamos fome nessa época mesmo. Era... a gente servia porções de frango, tudo e, muitas vezes quando tava no finalzinho a porção eu perguntava se eu podia tirar a porção de frango pra poder sobrar um pouquinho, pra gente poder comer na mistura é... quando pediam... quando pediam batata frita a gente cozi... fritava a batata e guardava a casca pra poder comer a casca de batata no arroz no outro dia e fomos passando dificuldades. O bar não deu certo, fechamos e fomo... aí, a gente sempre trabalhando, tudo, né, e... o Jorge, ele é um bom cozinheiro, e eu sou meio cara de pau, aí ele fazia pão caseiro e eu... saia de manhã vendendo pão caseiro, batendo de porta em porta. E a tarde a gente fazia broa, de fubá e pão de queijo, congelava e... eu saía à tarde vendendo broa de fubá e pão de queijo, e... se era Páscoa, também fazia ovo de páscoa pra poder vender pros amigos, é... Natal, panetone pra vender pros amigos e procurando arranjar um emprego e tal, né? E falou, assim, de fazer um curso e foi onde a gente descobriu a nossa profissão que a gente atua hoje, né? Aí com muita dificuldade fomos tocando a vida e hoje, graças a Deus, a gente já tá há 16 anos junto, nem com tanta dificuldade que a gente passou... a gente, graças a Deus, temos uma vida... a gente não é rico, mas a gente tem estabilidade financeira, temos um emprego, uma escola, que é conhecida na cidade e na região, então a gente pode... é... oferecer uma vida é... legal pra nossa filha.

Entrevistador: E o que você me diria que é o melhor dessa relação de vocês dois?

Aloísio: Eu acho que nós somos companheiros, nós somos cúmplices, a gente se respeita, a gente, ao mesmo tempo que... você conviver com uma outra pessoa você tem que abrir mão de algumas coisas tuas pra poder atender as... vontades da outra pessoa e... mas isso dentro 
de um equilíbrio, entendeu? E a gente... a gente vive numa boa, a gente nunca entra em atrito, quanto a isso... quando eu quero fazer alguma coisa o Jorge me apóia, ele faz, quando ele quer fazer alguma coisa eu também apoio e faço.

Entrevistador: Sim.

Aloísio: Muitas vezes sem... as... na vida, você vive com outra pessoa, independente de ser um relacionamento amoroso, afetivo ou profissional, o convívio com uma outra pessoa é assim... uma hora você, outra hora é a pessoa, é assim.

Entrevistador: Tá... e o que que você me diria que é o mais difícil da relação de vocês?

Aloísio: Então, o nosso relacionamento é baseado nisso. A gente... se completa, a gente se... nós somos cúmplices, né?

Entrevistador: Tá certo. E o que você me diria que é o mais difícil da relação de vocês e por quê?

Aloísio: Ah, eu acho... entendi... é um relacionamento normal... é um relacionamento normal. Pode-se dizer que o mais difícil é acordar de manhã, um baita frio, chovendo, você ter que sair pra trabalhar. Tocar o dia-a-dia.

Entrevistador: Poderia me contar de alguma situação que melhor mostra como é a relação de vocês?

Aloísio: A nossa relação é igual a qualquer outra relação de duas pessoas que moram juntas Se for dois pais, se foi... se são... aliás, se for um pai com o filho, se for dois irmãos, se for uma avó com uma filha, é... somos duas pessoas normais, é... a única coisa, a única diferença, é que nós somos homossexuais e isso, essa diferença, só é constatada sexualmente, e nisso, ninguém mais participa. É dentro de um quarto, em cima de uma cama, com a porta fechada. Então, nós não temos nada de diferente de outras pessoas. Nós não somos bichos, nós não somos anormais. Nós não somos extraterrestres. Nós somos normais como qualquer um... qualquer outra pessoa. As pessoas acham que a gente... num sei se todo mundo acha que a gente é dif... esses conceitos. Acordo de manhã, eu faço cocô, eu tomo café... (risos)

Entrevistador: E como é que era a tua família de origem?

Aloísio: Como é que era?

Entrevistador: É, o que você pode me contar da tua família de origem?

Aloísio: Ó, é... ah, eu... eu sou o caçula, de uma família de 3 irmãos, mas eu sou a raspa do tacho, e eu, quando eu nasci, meu irmão e minha irmã já eram casados, cada um tinha 1 filho...

Entrevistador: Que mais?

Aloísio: E minha mãe, meu pai... os meus sobrinhos, os meus sobrinhos, com minha irmã, meu irmão... uma família normal. Uma família normal. Cresci... minha mãe trabalhava, minha mãe tinha comercio, com meu pai. Trabalhei... comecei a trabalhar desde... vou por aí, Luiz?

Entrevistador: Sim, me conta. 
Aloísio: Comecei a trabalhar desde moleque no comércio da minha mãe, do meu pai, ajudando lá, no bazar, no mercadinho e... depois, com 14 anos, comecei a trabalhar fora, de office boy, numa empresa multinacional. Depois eu trabalhei num banco... de escriturário e... normal, a vida normal, família normal.

Entrevistador: Tá bom. E há quanto tempo você tá casado?

Aloísio: Eu e o Jorge, a gente já está há 16 anos juntos.

Entrevistador: E como é que foi a decisão de vocês ficarem juntos? Como é que vocês decidiram ficar juntos?

Aloísio: Foi amor a primeira vista.

Entrevistador: Conta mais a respeito.

Aloísio: A gente se olhou, se apaixonou... a gente... se conheceu, e é... o Jorge morava sozinho e eu também já tava querendo, acho, mesmo sair do armário, tudo. Já decidimos ir morar juntos, tudo.

Entrevistador: E como é que os membros da tua família se relacionam com o Jorge?

Aloísio: Meus sobrinhos chamam ele de tio. Minha irmã chama ele de cunhadinho. É assim, normal.

Entrevistador: E sempre foi assim?

Aloísio: Hoje, hoje... no começo... não... no começo... no começo, ninguém quer, né... que o filho seja homossexual, que seja apedrejado. Sabe que vai ser... todo mundo quer... que todo mundo quer que seja... o engenheiro, médico formado, bonitinho, né? Isso daí, agora... eu num tava muito preocupado com o quê minha família ia querer. Se eles quisessem me aceitar, assim, ótimo, senão, tudo bem. E... no fim eles acabaram... eles também não sabiam os conceitos que eles tinham... os conceitos que eles tinham eram outros. Aí, como eles acabaram convivendo com... com a gente... e descobriram que não era nada daquilo que eles imaginavam, bom... e acabaram aceitando, e hoje... a gente vive todo mundo muito bem.

Entrevistador: E você tem acompanhado a discussão, o debate sobre a adoção...

Aloísio: Tenho sim.

Entrevistador: E qual que é a tua opinião?

Aloísio: Ah, a minha opinião... eu acho que, a gente tá aí, mostrando que nós som... pra sociedade e pra muitos juízes aí, preconceituosos, que nós também somos... tão capazes... como qualquer casal heterossexual. Aliás, as pesquisas em países onde há a adoção homoafetiva autorizada mostram que, a maioria das crianças devolvidas, após o período de convivência para uma possível adoção, a maioria são devolvidas por casais heterossexuais e muito... é muito pequena a quantidade de crianças devolvidas por casais que tão passando o período de convivência... de casais hetero... é... homossexuais. Então, eu acho que, existem hoje no Brasil cerca de 8000 crianças disponíveis pra adoção e uma fila de casais heterossexuais, querendo adotar, de 7000 crianças. Eu acredito que, eu li... e praticamente 90\% desses 7000 casais heterossexuais não querem crianças acima de 2 anos de idade, então eu acho que a adoção por casais homossexuais seria uma ótima saída pra diminuir o número 
de crianças, principalmente que estão numa... numa... numa... idade acima de 2 anos de idade a encontrarem uma família. Eu penso assim.

\section{Entrevistador: E me conta uma coisa, O que é família pra você?}

Aloísio: Eu acho que família é uma... aí, eu num sei não, família pra mim é... aquele... a minha família hoje... a minha família de hoje, né, eu tô formando ela, né? Ela era... antes era só eu o Jorge, tudo, na realidade a gente num era uma família, a gente era... nós éramos dois amantes, dois namorados, assim, que morávamos.. duas pessoas que se amavam, que se gostavam junto. Com a chegada da minha filha isso... nossa... nosso relacionamento acho que passou a ser uma família, né? Então, agora, e mudou alguns conceitos, pelo menos pra mim... a gente... passei a rever alguns conceitos meus de... é... projetos de vida, de... renda, de... estabilidade financeira, religião. Então, agora, eu tô formando minha família, junto com o Jorge, com a minha filha, futuramente esperamos novamente mais uma criança. E eu quero, assim, vejo minha família com a gente se apoiando, a gente se ajudando, nós, como adultos, orientando elas pra crescerem, é... se tornarem pessoas... perante a sociedade, que possam também tá ajudando outras pessoas e pessoalmente crescerem, se formarem, serem pessoas de respeito, que consigam seus objetivos, em cima do seu esforço, do seu trabalho. Ah, e família, pra mim, isso é o que é agora. Agora, o que... pra mim, eu espero que essa minha família se torne o que a minha família anterior, que ainda é, né? Que é meu pai, minha mãe e meus irmãos... se torne aquilo que essa família pra mim significou pra mim, é... o apoio, uma base, uma estrutura familiar, é... alegria, carinho, né? A gente... aquela união, aquela preocupação de um com o outro, sempre, até hoje a gente liga um pro outro, a gente é... tá ligado espiritualmente, e também, sei lá... a gente... eu penso na minha irmã, ela me liga, assim, uma coisa telepática tem então eu acho... eu espero que a minha família de hoje... o Jorge, a nossa filha e uma próxima, se torne a família que eu... fique igual à família de onde eu saí.

Entrevistador: E sobre a adoção, especificamente, você teve critérios específicos quando vocês resolveram adotar?

Aloísio: Não. Tá. A gente queria uma... era só... a gente queria uma menina, porque a gente... iria se identificar mais, assim, porque pode enfeitar, aquela coisa de... de pôr roupinha, cabelo, então a gente... acredito que a gente ia curtir mais uma menina do que um menino. E... a gente sabia também que se a gente pedisse bebê ia demorar mais pra chegar, então nós escolhemos uma criança acima de dois anos de idade. Ah, o único critério assim que eu procurei... que eu falei, que eu não queria uma criança doente, com problemas físicos, é... assim... ou com AIDS, uma soropositiva, alguma coisa assim, porque... é como se fosse uma... quando a nossa filha tava pra chegar, se eu tinha opção pra essa escolha, eu não poderia escolher uma criança nessa situação porque... talvez ela seria a única filha, entendeu, então... essa criança talvez seria a única filha, então era... a filha que eu espero viver o resto da minha vida, com ela pra sempre, e não uma criança que fosse morrer logo. Depois, agora, da garantia da chegada dela, às vezes futuramente, mais pra frente, talvez daqui uns 10 anos, é... cert... eu... eu... penso às vezes em ter uma criança com problemas, né? Uma com Síndrome de Down, algum problema sério, até, mas isso se eu tiver preparado e tiver condições pra... pra tá cuidando é... muito bem dessa criança, né? Talvez minha aposentadoria, talvez, se vier legal, assim, se tiver condição de ter uma criança pra eu cuidar, assim, seria... eu penso nisso, futuramente, mas não agora, no momento não.

Entrevistador: Queria te agradecer imensamente porque eu acho que foi muito boa a tua entrevista, mas eu queria só complementar com o seguinte... tem mais alguma coisa que você acha que você pode me contar que eu não te perguntei, mas você acha que seja relevante ter numa entrevista como essa? 
Aloísio: Bem, eu acho que seria legal você tá pessoalmente aqui convivendo com a gente pra você ver como é que é, você não acha? É... pra você viver, pra você vivenciar o que a gente vive, né? Porque, de repente, era muito... eu posso talvez aqui... você sabe como é que é... de repente eu posso tá fazendo um teatrinho aqui, falando o que talvez seja legal e benéfico pra mim, e de repente a realidade seja outra. E outra coisa, também, assim... eu num sei... eu num consigo entender porque que se questionam tanto o lado de homossexuais conviverem com crianças, num sei o que, num sei o que lá na Universidade, porque... o que... o que caracteriza um casal homossexual é o ato de eles... dentro de um quarto... e num interessa mais a ninguém, sabe, ninguém mais participa disso, é... é outro departamento. Eu acho. 


\subsection{3 - FÁBIO}

Fábio: entrevistado.

Jorge: companheiro de Fábio.

Entrevistador: Vamos começar falando um pouco da tua história com teu parceiro. Eu queria que você contasse um pouco dessa história, começando por onde você quiser, fazendo os destaques que preferir.

Fábio: É... a gente se conheceu assim, numa situação por acaso. Primeiro nos tornamos amigos e depois houve um... um relacionamento mais profundo. Ahn, nós nos conhecemos num, num bar, que... eu conto que foi por pura coincidência porque fui lá atrás de um amigo meu... que andou aprontando umas coisas com os pais aí e eu fui lá pra dar um... chacoalhão nele.

Entrevistador: Hum.

Fábio: E essa pessoa não estava lá, né? Não estava no bar. E eu tava meio que... tava de chinelo de dedo, short camiseta, pra você ter uma base (risos), tão furioso que eu tava com esse meu amigo.

Entrevistador: Hum.

Fábio: Aí eu, já que eu tô aqui vou tomar uma cervejinha, tal, né? Sentei lá e... né? O barzinho tinha karaokê, eu fiquei lá ouvindo o povo cantar. E ele tava cantando. Nossa... que interessante! Fiquei ali, quietinho no meu canto, aí ele começou a me paquerar... a gente começou a se paquerar, tal, depois, começamos a conversar, marcamos de sair junto... e ficamos tendo essa... amizade, até que resolvemos, assim, vamos, vamos namorar? Ficamos namorando... seis meses, mais ou menos, aí resolvemos morar junto.

Entrevistador: Hum.

Fábio: Né? Eu já morava sozinho... ele morava com a família, tal e ele tava querendo um espaço pra ele também. Aí falei: ah, tudo bem, vamos morar junto. Foi aí que nós fomos... construir nossa família.

Entrevistador: U-hum.

Fábio: E virou uma grande família.

Entrevistador: E como é que foi isso?

Fábio: É... como é que foi?

Entrevistador: Você falou em uma grande família.

Fábio: Uma grande família porque uniu, tipo assim, a minha família com a dele, né?

Entrevistador: Ah, tá.

Fábio: Então... porque nós temos essa facilidade assim, ser aberto com, com as famílias, uma coisa mais gostosa, né? É que você apresenta a pessoa, não vai apresentar como amigo. É meu companheiro ou meu namorado. 
Entrevistador: É?

Fábio: Entendeu? E... minhas sobrinhas... a... adoraram ele logo de cara, a família dele, todos me acolheram muito bem.

Entrevistador: Hum.

Fábio: Tenho um ótimo relacionamento com eles e vice-versa. Então... almoço... de família, reunião de fim de ano, essas coisas a gente... o Natal é com uma família e Ano Novo com outra pra não ter, sabe?

Entrevistador: Não ter?

Fábio: Não ter confusão.

Entrevistador: Hum.

Fábio: E eles também vem... em casa, né? Minha irmã, minhas sobrinhas, meus irmãos, a mãe dele sempre tá em casa. Então, como eu te falei, virou uma grande família, né?

Entrevistador: Entendi. E o que você diria que é o melhor nessa relação, e porquê?

Fábio: O melhor, pra mim... nessa relação, assim, particularmente, porque, foi a primeira vez que fui morar com outra pessoa. Eu tive outros relacionamentos, mas cada um na sua casa, né? É... algumas pessoas, assim... eu não tinha esse contato com famílias, né? Porque eram mais reservados. De repente, às vezes, saía, se encontrava com algum parente. Ah, é meu amigo, esse aqui é meu amigo. Então... então fica uma coisa meio, pra mim, desconcertante, desagradável. E nessa relação, não. Nessa relação é um casal, né? Como uma família, a minha família, então, isso pra mim é muito bom, muito importante.

Entrevistador: É?

Fábio: Ver esse outro lado, assim, que pode ser feito isso, que dá pra conviver realmente como uma família. Então pra mim foi muito agradável isso.

Entrevistador: Tá. E o quê que você diria que é o mais difícil nessa relação?

Fábio: A parte difícil...

Entrevistador: É.

Fábio: A parte difícil é... é o dividir espaço. Acho. Como eu morava sozinho... é... deixava as coisas do jeito que eu queria, fazia o que queria, não dava muita satisfação, tipo: ah, porque não lavou roupa, né? Ou porque não limpou a casa, porque cê ta andando pelado pela casa? (risos) Sabe? Assim, e eu sempre fui bem à vontade, então, se cê tá com uma pessoa que não tá acostumado com certas coisas que cê faz, é complicado, né? E pra ele também, porque ele, às vezes faz umas coisas que eu não gosto, então...

Entrevistador: Você pode dar um exemplo?

Fábio: Posso (risos) eu odeio quando, quando eu chego em casa, eu gosto de chegar, tomar um banho, ficar sossegadinho, quietinho, assim... conversar, bater um papo, eu odeio chegar em casa e o som alto, eu querendo falá de um assunto e ele não querendo ouvir, tá curtindo 
aquele momento dele, né? Que ele tá, como ele é mais novo e tal, ele tem uma outra energia, uma outra... então isso me incomoda... um pouco, mas... E... e eu sei que uma coisa que incomoda muito ele, ele é, ele é muito organizado... e eu sou desorganizado. Um desorganizado organizado, tipo assim, chegava, arrancava a roupa e deixava em cima da cama. Aí eu não gosto que deixa roupa em cima da cama, já põe pra lavar ou pendura no varal! Então, a briga com ele é essa comigo, e outras coisinhas bobas assim, né?

Entrevistador: Tá certo. E tem alguma situação que você acha que podia contar que ilustra como é que é a relação de vocês?

Fábio: Que for importante para o nosso relacionamento? Eu acho que foi... o companheirismo muito grande de ambas as partes mas, é... ele é muito presente na minha vida, nos momentos mais difíceis, ... teve uma época que fiquei muito doente ele cuidou muito bem de mim, ele se preocupava muito. É... a gente troca muito... muitas idéias, compartilha muita coisa, ... se eu sair com alguns amigos, eu faço questão que ele esteja presente e vice-versa, então é... são coisas assim... pra mim são importantes, é... o quê mais? Acho que companheirismo me... mesmo, né? Da parte dele, pra mim foi muito importante.

\section{Entrevistador: Hum}

Fábio: Realmente, é... estar com uma pessoa, um companheiro presente ali, nas horas boas e nas... nas más, né? Então pra mim isso foi muito importante, isso me fez ver realmente o que é ter um... um relacionamento, ser um casal.

\section{Entrevistador: U-hum.}

Fábio: Antes eu não tinha. Tinha namorados, né? Mas um relacionamento firme assim, não. É... ele é uma pessoa alegre, extrovertido, todo mundo gosta dele. Então, isso... é... ele é um bom companheiro... ele é um grande amante.

Entrevistador: Eu também queria saber o seguinte, o quê você pode me contar sobre como era sua família de origem?

Fábio: Minha família de origem?

Entrevistador: É.

Fábio: É meio delicado (risos), porque, eu viví algumas situações delicadíssimas, é... eu perdi minha mãe muito nova, minha mãe tinha, trinta e poucos anos quando ela faleceu, eu tinha doze anos de idade. Era uma barra. Antes de eu nascer... se separaram, meus pais se seperaram, depois que minha mãe faleceu eu fiquei na casa de um irmão, fiquei na casa duma tia, fui morar com minha madrinha... aos quinze descobri que meu pai não era meu pai e, aí já fiquei naquela, aquela coisa revoltada, né? Aos dezesseis anos fui morar sozinho já... e sempre, assim, nunca tive apoio nem, nem de um, nem do biológico nem do... do outro. Então sempre ralei, então minha vida não foi tão fácil, não. Teve uma fase que eu entrei nas drogas, né? Pra variar... mas coisa leve, macoinha ... mas também... caí na real logo que não era aquilo que eu queria e consegui me livrar, rápido. É... meus irmãos eu tive, na época, tive pouco contato com eles... Nós viemos realmente ter é... uma vida um pouco mais assim, unida, depois dos meus trinta anos, porque hoje nós somos bem unidos, né? Apesar da distância, eles não moram aqui... Então é isso, mas, foi um pouco tumultuada e... sem grandes... é... trocas de carinho, afeto, aquela fase que eu acho muito importante para a adolescência, é... Porque na verdade... eu pulei do, tipo, dos oito anos até os doze quando minha mãe faleceu, eu já fui para fase adulta, eu acho. 
Entrevistador: Hum.

Fábio: Porque minha mãe tentou suicídio, ficou com problemas de saúde e eu que cuidava dela na época. Cuidava dela e de um irmão mais novo, filho de outro pai. Então eu assumi uma responsabilidade muito grande... então pra mim, assim, aquela fase de brincadeiras, de... de sair com coleguinhas, de ír pra casa de amigos pra estudar, fazer amizades... eu tinha pouquíssimas amizades na escola na época... porque eu era mais voltado pra minha mãe, entendeu?

Entrevistador: Hum.

Fábio: Então eu me podei. E... e hoje até que tô bem, tô bem com minha família.

Entrevistador: Você tem contato com seus irmãos?

Fábio: Tenho.

Entrevistador: Tem?

Fábio: Tenho. Tenho, por... então, depois dos trinta é que, nós ficamos mais unidos. Todos casaram e todos tem família... tem a sua família, tenho dezesseis sobrinhos, sou tio-avô de cinco, tem uma que mora fora do Brasil. E... e hoje, hoje nós somos mais unidos.

Entrevistador: É?

Fábio: Por incrível que pareça, né? Depois de tanto tempo a gente ter mais contato e tal.

Entrevistador: E como é que os membros de sua família de origem se relacionam com seu parceiro. Se você puder, conta uma situação à título de exemplo.

Fábio: Assim, eles o receberam o Jorge muito bem, né? Até hoje todos adoram ele. É... que isso fica bem claro que, é... em algumas situações, alguns atritos, que nós tivemos, tipo comentava com minha irmã ou com meu irmão, ou mesmo com meus sobrinhos tal, eu tava, tipo... eu esperava uma reação assim: ah, tio, deixa pra lá, né? Eles iam passar a mão na minha cabeça, né? Me apoiando, pelo contrário, apoiaram ele. Mas tio, cê tá errado, não é assim que funciona.

Entrevistador: Hum.

Fábio: Por que sou meio cri-cri em alguns assuntos, assim, chato... e eles tavam vendo a situação, e então isso me deixava meio pê da vida.

Entrevistador: É?

Fábio: Então, vai ficá do lado dele ou do meu? Não, do lado de quem tá certo, ele tá certo. Então, minha família me ajudou um pouco nisso, assim... nessas situações. Tio, cê tem que tem noção de que tá errado. Meu irmão, cê tá errado, ele tá certo.

Entrevistador: Via de regra, situações em que vocês estavam discordando?

Fábio: A-ham (risos). Então eu acho interessante isso.

Entrevistador: Tá bom. 
Fábio: Mesmo da parte da família dele teve o contrário.

Entrevistador: Hum.

Fábio: Porque ele também tem um irmão, que também era casado com um outro rapaz e às vezes a mãe ficava assim... em vez dela apoiar os filhos, né?

Entrevistador: Hum?

Fábio: Ela puxava a orelha deles: não vocês tão errados, seus parceiros tão certos. Então teve, teve essa... Ahn... uma delas é assim ... como nós ficávamos muito juntos, então tinha época em que, por exemplo, ele falava assim: ai, eu vô pra cidade Z. É a família dele, é... mora em Z. Vou ficar dois dias na casa da minha tia, tou com saudades, não sei o quê. Não, não vai não, vamos deixar mais pra frente. Não, mas eu quero ir. Tá, então tá. Então ele ia... só que em vez dele ficar dois dias, eu esperava ele voltar um dia antes. Só que, na verdade, às vezes acontecia dele ficar tipo três dias.

Entrevistador: Hum.

Fábio: A família dele é grande, então tem que ficar na casa de um, de outro, tal, então aquilo me deixava muito pê da vida.

Entrevistador: U-hum.

Fábio: Então eu brigo com ele. Pô, cê me larga sozinho aqui e tal, tal, tal... pra ficá só com sua família, não sei o quê. Fosse e voltasse, tô aqui, né? Na nossa, sua casa. Então ele discordava disso, eu brigava. Um pouco isso, assim, queria só pra mim, né? Ele tem a vida dele... Aí então, é, então, tem que concordar, tá todo mundo contra... E... às vezes, eu era assim, meio mão de vaca, ele já era mais aberto... Pra quê comprar uma camisa dessa? Mas eu gosto, eu quero usar essa camisa. Mas é uma nota! Não sei o quê, aí ele, a gente ficava discutindo esse tipo de bobeira.

Entrevistador: U-hum.

Fábio: Aí teve uma sobrinha que morou com a gente uma época, a Andréia. Tio, mas se ele gosta, ele quer, se ele tá podendo, deixa ele. Não, mas isso a gente pode usar pra outra coisa, né?

Entrevistador: Hum.

Fábio: Mas pra quê fazer a sua vontade, deixa ele fazer a vontade dele. Você tá errado, o dinheiro é dele. Então é esse tipo de coisa.

Entrevistador: E me conta o seguinte, você tem acompanhado o debate sobre a adoção por casais gays?

Fábio: Olha, é... eu... acompanhando assim, firmemente, não, mas eu ouvi umas coisas, inclusive sobre o casal que adotou crianças aqui na cidade. É...

Entrevistador: Hum.

Fábio: Meu companheiro, ele adora criança também. Nossa! É, ele é uma eterna criança, então, cê já viu. 
Entrevistador: Hum.

Fábio: E... tivemos contato com essas crianças, tal. Fiquei muito feliz quando fiquei sabendo que eles tavam em com o pessoal lá. E o rapaz, pessoal de Catanduva. Né? O casal de Catanduva que adotou a menininha.

Entrevistador: E tem algum aspecto desse debate que te chama atenção?

Fábio: Em relação à adoção?

Entrevistador: É, a todo o debate que está acontecendo nesse momento à respeito desse assunto.

Fábio: Eu acho que estamos evoluindo, né? Assim, é... e.... e a concepção família gay, e eu acho que tá, tá mudando um pouco, a sociedade tá mudando um pouco. Tem que mudar muito ainda, mas já, já demos alguns passos... eu acho muito interessante isso. Eu particularmente... eu, eu... pra mim, hoje, eu, eu não, não, não teria, essa coragem... uma por que eu acho...

Entrevistador: Coragem de quê?

Fábio: De adotar.

Entrevistador: Tá.

Fábio: Eu acho que o casal tem que ter uma boa estabilidade assim, não só financeira, mas emocional. Realmente é isso que vamos querer, tal, vamos atrás e tal. Eu já te falei, eu adoro criança, gosto muito, mas pra mim, assim, não, ho... hoje não estaria preparado.

Entrevistador: U-hum.

Fábio: Né? Pode ser que daqui a algum tempo estaria, mas agora, fora de cogitação.

Entrevistador: U-hum.

Fábio: Eu admiro que tem coragem de assumir esse, esse compromisso. Mas eu não.

Entrevistador: E me conta o seguinte, o que é a família pra você? Como é que você define a família?

Fábio: O que é família pra mim? É, é uma pergunta delicada, porque eu não tive muito, quando era criança, muito envolvimento com a minha família, minha família era minha mãe, que eu perdi muito cedo... agora que eu tô resgatando esse lance de família com a minha família, né? Mas, acho que família... é... é aquele convívio, troca de carinho é... é troca de... de conhecimentos e... dá bronca na hora que dá bronca, dá risada na hora que tem que dá risada, quando vê, fazer carinho, cafuné... Na hora que cê tá precisando. É participar na hora que um irmão tá com problema, ír lá, se você puder ajudar, né? Na hora de dá bronca, dá bronca enfim, e... ... eu não posso te falar muito sobre família, que eu realmente não tive muito, tô te passando realmente o que eu acho, né? Como que se, é o que eu tô vivendo hoje, com meus irmãos e mi... minhas sobrinhas... Eu adoro todas, né? Então eu ajudo, o que eu puder. Aconselhá-lhas. Inclusive eu tenho umas... umas sobrinhas que vieram morar comigo... porque minha cunhada é um pouco... ela num... pela criação dela ela num tinha muita experiência em lidar com, com a... adolescência e como eu, eu tenho uma visão um pouco mais, vamos dizer assim, moderna, né? 
Entrevistador: Hum.

Fábio: Então elas vinham me consultar e perguntar, tirar dúvidas, sobre... sobre namorado, sobre menstruação, sobre um monte de coisa. Aí eu sempre, sempre fui uma pessoa muito aberta com elas, né? Então, é, eu acho que é isso, família é... é você tá pronto pra poder tá participando ali da vida de irmãos, de parentes, sobrinhos e filhos. Tem que ter uma cabeça boa pra saber lidar com isso.

Entrevistador: E você disse que a priori não adotaria.

Fábio: Não.

Entrevistador: Então, eu ia perguntar o seguinte. Se algum dia você mudar de idéia, você já disse que gosta de criança, e se resolver adotar, você imagina que teria critérios específicos pra escolher uma criança pra ser adotada?

\section{Fábio: Critérios?}

Entrevistador: É.

Fábio: Critérios, eu acho que... não. Eu, por exemplo, eu, se eu puder... tá, vamos colocar, se eu pudesse, se eu tivesse condições financeiras, psicológicas e tivesse pronto. Eu quero uma criança, eu quero cuidar de uma criança. Eu... sabe, não é... é aquela que te toca mais o coração, entendeu? É... ... tem uma menininha lá no V (abrigo para crianças abandonadas) que eu, eu acho ele uma, uma gracinha, um pitéozinho, que ela é muito carinhosa, então, eu acho que é essa troca, né? De ir, ver, conhecer, ir lá e sentir, então assim, falando fisicamente, não, num... num teria nenhum...

Entrevistador: Bom, o que toca o coração é um critério.

Fábio: Sim, mas tô falando fisicamente, sim, porque tem pessoas que vai tipo: ah, quero uma loirinha ou quero uma moreninha.

Entrevistador: Sei...

Fábio: Não, mas, acho que é uma coisa mais... sentimento, aquela coisa de... né? Pelo coração.

Entrevistador: E eu te perguntei sobre a... o debate sobre adoção, né? Você tem acompanhado o debate sobre a união estável?

Fábio: Atualmente não. Eu soube que tem um contrato... não é contrato... é alguma coisa, é seria algum contrato que tão fazendo, inclusive aqui na cidade já, já, já tem pessoas que fizeram... união de... não me lembro agora. Eu acho que sim... é... tem... eu tenho um amigo, que inclusive, o parceiro dele faleceu faz pouco tempo, os dois eram grandes amigos e ele tá vivendo uma situação muito desagradável. Eles ficaram juntos... sete anos. E... agora tá uma situação muito delicada, porque uma tia pegou os documentos do rapaz que faleceu, e esse meu amigo ia dá entrada no... seguro que ele tem no trabalho, pra receber o pedido de aposentadoria do INSS, e a tia simplesmente foi lá, pegou os documentos e não quer devolver os documentos. E já suspeita que ela já tenha recebido o seguro no nome dela. Então eu acho que tem sim um, alguma, algum documento, alguma cláusula que dê alguma certa segurança pra ambos, né? A gente não sabe o dia de amanhã. 
Entrevistador: Hum.

Fábio: Pra num tá vive... vivenciando isso que meu amigo tá vivendo, vivenciando agora, né? Moraram juntos, compraram coisas juntos, é... participaram, assim, do sofrimento, né? Aquela coisa da doença, que o Olavo ficou muito doente, muito doente, então os dois se uniram pra lutar pra para sobreviverem e a família não tava, a família dele, principalmente essa tia, por que a mãe e o pai já, já faleceram. Só apareceram quando ele estava no estágio final mesmo e... apareceram num dia e no outro dia foram lá, cataram os documentos e... então a outra pessoa agora ficou... Tá, tá brigando na justiça pra ver se consegue alguma coisa. Mas aí é que tá, não tem nada assinado, né? Então vai ter que colher depoimentos, juntar documentos, com... com o mesmo endereço dos dois, quanto tempo, moravam junto, enfim, mais dor de cabeça, né? Se tivesse pelo menos um contrato, alguma coisa, assim, que afirmasse essa união seria mais fácil.

Entrevistador: É. E tem mais alguma coisa, que você acha que vale a pena acrescentar na sua entrevista, que você acha que eu não perguntei, que te passou pela cabeça, e você gostaria de falar?

Fábio: Olha, eu acho... como eu te falei, é a minha primeira experiência de tá morando com uma pessoa, de tá compartilhando, dividindo o mesmo teto, assim... Pela companhia é... eu acho que é válido construir uma família... né? Porque o tempo passa, a gente sempre tá a procura de alguém. O que infelizmente... o que no nosso meio ainda tem é... a questão de, de que você é pelo que você tem, né? Porque o pessoal mais novo tem, tá com essa mentalidade hoje. Tipo, você chega num bar te olham de cima em baixo pra vê que roupa você tem, que carro você tem, como você se comporta, estão preocupados com o físico, não com sua alma. Com o que você tem pra dar, a experiência. E acabam indo, pulando de galho em galho. E quando você acha uma pessoa que você vê ali, que é legal, que você possa, de repente ir conhecendo e... construir alguma coisa, pra ter um relacionamento mais firme, assim, eu acho que... vale muito à pena.

Entrevistador: Hum.

Fábio: Pra tentar construir uma nova família. É isso.

Entrevistador: Ok, muito obrigado. 